\title{
Electropositive Promotion by Alkalis or Alkaline Earths of Pt-Group Metals in Emissions Control Catalysis: A Status Report
}

\author{
Ioannis V. Yentekakis ${ }^{1, *}$, Philippe Vernoux ${ }^{2}$, Grammatiki Goula ${ }^{1}$ and Angel Caravaca ${ }^{2}$ \\ 1 Laboratory of Physical Chemistry \& Chemical Processes, School of Environmental Engineering, \\ Technical University of Crete (TUC), 73100 Chania, Crete, Greece; mgoula@science.tuc.gr \\ 2 Univ. Lyon, Université Claude Bernard Lyon 1, CNRS-IRCELYON-UMR 5256, 2 Avenue A. Einstein, \\ 69626 Villeurbanne, France; philippe.vernoux@ircelyon.univ-lyon1.fr (P.V.); \\ angel.caravaca@ircelyon.univ-lyon1.fr (A.C.) \\ * Correspondence: yyentek@isc.tuc.gr
}

Received: 23 December 2018; Accepted: 29 January 2019; Published: 5 February 2019

check for updates

\begin{abstract}
Recent studies have shown that the catalytic performance (activity and/or selectivity) of Pt-group metal (PGM) catalysts for the $\mathrm{CO}$ and hydrocarbons oxidation as well as for the (CO, $\mathrm{HCs}$ or $\mathrm{H}_{2}$ )-SCR of $\mathrm{NO}_{x}$ or $\mathrm{N}_{2} \mathrm{O}$ can be remarkably affected through surface-induced promotion by successful application of electropositive promoters, such as alkalis or alkaline earths. Two promotion methodologies were implemented for these studies: the Electrochemical Promotion of Catalysis (EPOC) and the Conventional Catalysts Promotion (CCP). Both methodologies were in general found to achieve similar results. Turnover rate enhancements by up to two orders of magnitude were typically achievable for the reduction of $\mathrm{NO}_{\mathrm{x}}$ by hydrocarbons or $\mathrm{CO}$, in the presence or absence of oxygen. Subsequent improvements (ca. 30-60 additional percentage units) in selectivity towards $\mathrm{N}_{2}$ were also observed. Electropositively promoted PGMs were also found to be significantly more active for $\mathrm{CO}$ and hydrocarbons oxidations, either when these reactions occur simultaneously with deNO $\mathrm{N}_{x}$ reactions or not. The aforementioned direct (via surface) promotion was also found to act synergistically with support-mediated promotion (structural promotion); the latter is typically implemented in TWCs through the complex (Ce-La-Zr)-modified $\gamma-\mathrm{Al}_{2} \mathrm{O}_{3}$ washcoats used. These attractive findings prompt to the development of novel catalyst formulations for a more efficient and cost-effective control of the emissions of automotives and stationary combustion processes. In this report the literature findings in the relevant area are summarized, classified and discussed. The mechanism and the mode of action of the electropositive promoters are consistently interpreted with all the observed promoting phenomena, by means of indirect (kinetics) and direct (spectroscopic) evidences.
\end{abstract}

Keywords: platinum; palladium; Rhodium; iridium; $\mathrm{NO} ; \mathrm{N}_{2} \mathrm{O}$; propene; $\mathrm{CO}$; methane; alkali; alkaline earth; platinum group metals; deNO $\mathrm{N}_{\mathrm{x}}$ chemistry; lean burn conditions; TWC; catalyst promotion; EPOC

\section{List of Contents}

2 Promotion Methodologies and Catalysts Formulations/Designs

2.1 Electrochemical Catalysts Formulations. The Electrochemical Promotion of Catalysis (EPOC) Concept . . . . . . . . . . . . . . . . . . . . 
2.1.1 Operation Modes of the Electrochemical Promotion of Catalysis (EPOC) . . . . . 5

2.1.2 Certain Characteristics of EPOC Concept: . . . . . . . . . . . . . 7

2.2 Conventional Catalyst Formulations. The Conventional Catalysts Promotion (CCP)

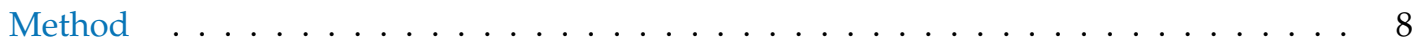

2.2.1 Estimation of the Promoter Coverage . . . . . . . . . . . . . 8

2.2 .2 EPOC and CCP Comparison Issues . . . . . . . . . . . . . . . . . 9

3 Results and Discussion 9

3.1 Promotion of Simple, "Model" Reactions . . . . . . . . . . . . . . . . . 9

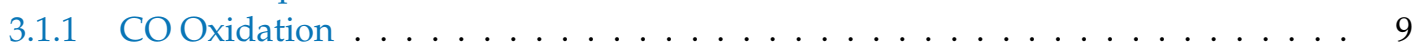

3.1.2 Light Hydrocarbons Oxidation . . . . . . . . . . . . . . . . . . . 17

3.1 .3 NO Reduction by $\mathrm{CO} \ldots \ldots \ldots \ldots \ldots$

3.1.4 NO Reduction by Hydrocarbons or $\mathrm{H}_{2} \quad \ldots \ldots \ldots$

3.1.5 $\mathrm{N}_{2} \mathrm{O}$ Decomposition and/or Reduction . . . . . . . . . . . . . . . 40

3.2 Electropositive Promotion of PGMs Operated Under Simulated Practical Conditions . . 45

3.2.1 Simulated TWC Conditions . . . . . . . . . . . . . . . . . . . . 45

3.2.2 Oxygen Excess Conditions (Simulated Lean-Burn and Diesel Exhausts Gases) 52

3.3 Mechanistic Implications: The mode of Action of Electropositive Promoters . . . . . . 57

3.3.1 Main Promotion Characteristics and Mechanistic Implications ～. . . . . . . . 57

3.3.2 Direct Spectroscopic and Other Analytical Technique Evidences . . . . . . . . . 63

4 Conclusions and Perspectives $\quad 68$

$\begin{array}{lr}\text { References } & 69\end{array}$

\section{Introduction}

The development of new catalyst formulations for a more efficient and cost-effective control of unburned hydrocarbons, $\mathrm{CO}$ and $\mathrm{NO}_{\mathrm{x}}$ pollutants emitted by mobile and stationary combustion processes is currently an urgent need [1-3]. Commercial three-way catalytic converters (TWCs) have been highly successful in controlling $\mathrm{NO}_{\mathrm{x}}, \mathrm{CO}$ and hydrocarbon emissions from conventional stoichiometric gasoline engines. However, some problems, that emerged during their four decades of implementation, concerning the economy of their production process, their composition, their operational/life time behaviour and their recycling still need to be resolved. The most significant issues of TWC technology are the following:

1. Commercial TWCs use formulations based variously on two or three noble metals (Pt, Pd and Rh) where $\mathrm{Rh}$ is essential for an efficient control of $\mathrm{NO}_{x}$ emissions ( $\mathrm{Rh}$ is highly effective and therefore the key component in TWCs for the NO dissociation/reduction; $\mathrm{Pt}$ and $\mathrm{Pd}$, although very active for $\mathrm{CO}$ and hydrocarbons oxidations, are almost ineffective for $\mathrm{NO}_{\mathrm{x}}$ reduction). However, $\mathrm{Rh}$ is rare, therefore its successful reduction or even replacement by another $\mathrm{De}-\mathrm{NO}_{\mathrm{x}}$ efficient catalyst in TWC formulations is highly desirable.

2. A small but significant portion of $\mathrm{NO}$ is still converted to the undesirable by-product $\mathrm{N}_{2} \mathrm{O}$ in commercial TWCs; Nitrous oxide emission control, due to $\mathrm{N}_{2} \mathrm{O}$ harmful impact on stratospheric ozone depletion and its outstanding global warming potential (the latter is about 310 and 21 times greater than that of $\mathrm{CO}_{2}$ and $\mathrm{CH}_{4}$, respectively $\left.[4,5]\right)$, is a current challenge in environmental catalysis technology.

3. TWCs recycling for the noble metals recovery is nowadays marginally profitable, mainly due to the costly final separation of the recovered noble metals; simpler TWCs formulations (i.e., consisting of only one noble metal) are expected to substantially reduce both TWCs' production and recycling costs. 
4. Commercial TWCs are no longer efficient in controlling $\mathrm{NO}_{\mathrm{x}}$ emissions from the advanced lean-burn and diesel engines that operate at net-oxidising conditions.

In general, catalytic systems with suitable efficiency under oxygen rich conditions are a great challenge in emissions control technology. Besides lean-burn and diesel engines' effluent gases, such conditions are also typical in several stationary processes of significant environmental footprint, such as in soil fuels combustion processes for heat production in industry, in solid wastes combustion processes and certain chemical processes such as ammonia oxidation processes (e.g., nitric acid plants), adipic acid and other specific industries.

Prompted by these issues, numerous efforts are currently reported in open literature, by several research groups, on discovering means for enhancing the catalytic performance of $\mathrm{Pt}$ and $\mathrm{Pd}$ or even $\mathrm{Rh}$, for reactions related to $\mathrm{CO}, \mathrm{NO}_{\mathrm{x}}$ and hydrocarbons abatement under stoichiometric and/or oxygen rich conditions. A notable part of these studies is focussed on the reduction or replacement of the $\mathrm{Rh}$ usage due to its scarcity and consequently higher cost compared to Pt and Pd.

It has been recently shown that the catalytic performance of precious metals can be strongly promoted by alkalis and alkaline earths for reactions related to emissions control catalysis. Two promotion methods were implemented towards this aim: (i) the Electrochemical Promotion of Catalysis (EPOC) concept or NEMCA effect (Non-Faradaic Electrochemical Modification of Catalytic Activity), proposed three decades ago by Vayenas and co-workers (e.g., [6-13]) and (ii) the Conventional Catalysts' Promotion (CCP), applicable by means of highly dispersed (supported) catalysts, as typically used in industrial applications (e.g., [14,15]). On these bases, rational/more efficient catalyst formulations and catalytic systems have been designed with significantly widened operational and/or implementation windows.

The present review summarises and comparatively analyses these literature results, paying attention on both fundamental and practical issues emerged. Mechanistic considerations (involving the mode of action of electropositive promoters in emissions control catalytic chemistry) are described in confrontation with recent spectroscopic and surface analysis studies evidencing their rightness.

\section{Promotion Methodologies and Catalysts Formulations/Designs}

Materials formulations and designs, experimental setup and other specific characteristics and/or rules regarding the two promotion methods, EPOC and CCP, are briefly described below.

\subsection{Electrochemical Catalysts Formulations. The Electrochemical Promotion of Catalysis (EPOC) Concept}

It has been shown by Vayenas and co-workers (e.g., [6,7]) that the chemisorptive and catalytic properties of metal catalysts, in the form of thin polycrystalline porous metal films, interfaced with solid electrolytes $\left(\mathrm{X}^{\mathrm{z}}\right.$-ionic conductors: $\mathrm{X}$ is the type of ion transferred, $\mathrm{z}$ is its positive or negative charge) are subjected to in situ controlled electrochemical promotion via external bias applications, that is, currents or voltages imposed between the catalyst metal film and a separate counter electrode deposited on the same solid electrolyte specimen, which constitute a solid state electrochemical galvanic cell schematically shown in Figure 1.

In this way, applying small electric currents (typically some tens of $\mu \mathrm{A}$ units) or potentials (typically -2 to $+2 \mathrm{~V}$ ) between the working (catalyst film) and the counter electrodes via a Galvanostat/Potentiostat (Figure 1), ions are supplied from (or to) the solid electrolyte to (or from) the catalyst-electrode surface. Ions flux direction is determined by the direction of the applied current in combination with their charge, while their flux rate by the Faraday's law, $\mathrm{r}_{\mathrm{z}}=\mathrm{I} / \mathrm{zF}$ (I is the applied current in A; $\mathrm{z}$ is the ion's charge; $\mathrm{F}$ is the Faraday's constant $=96,485 \mathrm{Cb} / \mathrm{mol}$ ). As we shall see in detail in Section 3.3, there is compelling evidence that these ions (together with their compensating charge in the metal thus forming surface dipoles) spill over (migrate) onto the gas-exposed catalyst surface, establishing an effective electrochemical double layer on the catalytically active surface altering its electron availability (work function). This strongly affects the binding strength of chemisorbed reactants and intermediates resulting to a significant modification on catalytic reaction rate (and 
or selectivity), typically greatly larger than the rate of ions flux that created these modifications (i.e., non-Faradaic behaviour), the so-called NEMCA (Non-Faradaic Electrochemical Modification of Catalytic Activity) phenomenon or EPOC (Electrochemical romotion of Catalysis).

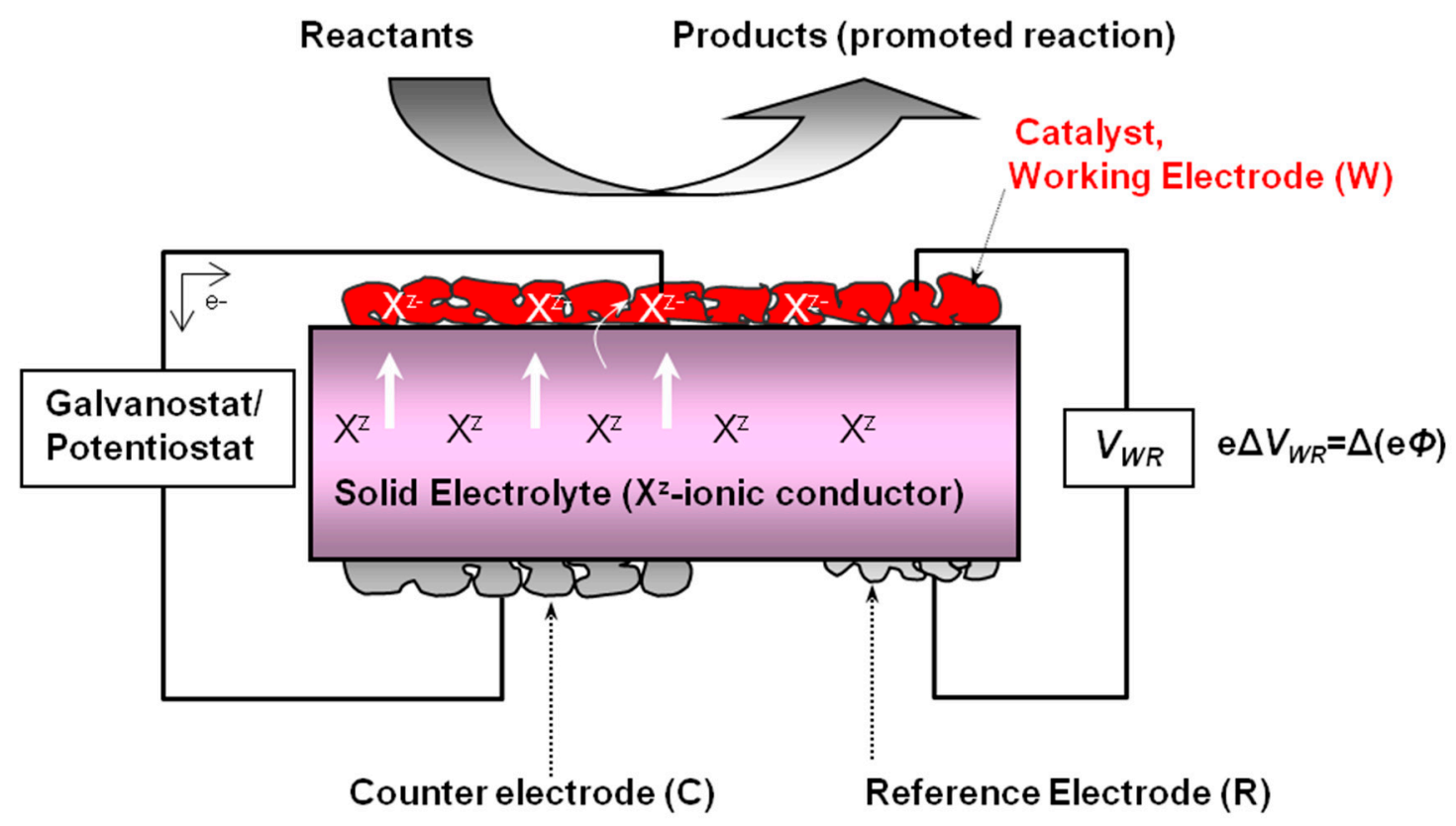

Figure 1. Schematic representation of a solid state electrochemical cell, through which the EPOC concept can be applied. X: type of ion transferred from the solid electrolyte to the catalyst surface and z: ion charge (e.g., $\mathrm{O}^{2-}, \mathrm{Na}^{+}, \mathrm{K}^{+}, \mathrm{H}^{+}$).

The EPOC was then applied to a large number of catalytic reactions $[6,7,13]$, including reactions related to emissions control catalysis (e.g., [16-22]). Numerous EPOC studies regarding electrochemically imposed electropositive promotion by alkalis of Pt-group metals' catalysed emissions control reactions have also been reported, which are subject of the present review.

Alkali-conducting solid electrolytes such as $\mathrm{Na}^{+}$or $\mathrm{K}^{+}$substituted $\beta$ - and $\beta^{\prime \prime}$-aluminas, ( $\mathrm{Na}$ or $\mathrm{K})_{1+\mathrm{X}} \mathrm{Al}_{11} \mathrm{O}_{17+\mathrm{X} / 2}$ and $(\mathrm{Na} \text { or } \mathrm{K})_{1+\mathrm{X}} \mathrm{M}_{\mathrm{X}} \mathrm{Al}_{11-\mathrm{X}} \mathrm{O}_{17}$, respectively [6], are used for the construction of electrochemical galvanic cells with the following configuration (Figure 1):

PGM-film electrode / alkali-conducting solid electrolyte / inert counter electrode (e.g., Au)

These cells are exposed to the reacting gas mixture by means of a continuous flow well-mixed reactor, as that shown in Figure 2, described as "single-pellet" (reactor) configuration and behaved similarly to a classical Continuous-Stirred-Tank-Reactor (CSTR) [12]. Controlled amounts of promoting species (alkali cations) can therefore be in situ supplied through the solid electrolyte onto the catalyst surface, causing significant alterations on the catalytic properties of the latter.

For the sake of simplicity, inert (in respect to the studied reaction) counter and reference electrodes (e.g., Au) are typically applied in EPOC studies conducted in reactor configurations similar to this shown in Figure 2; avoiding their participation in the catalytic reaction vectors (activity, selectivity) simplifies the data analysis, interpretation and understanding. It is also worth noting that besides their role as an in situ and reversible promoting species sources, solid electrolytes involved in the configuration of EPOC galvanic cells do not actually play any additional role on the promotional phenomena obtained. 


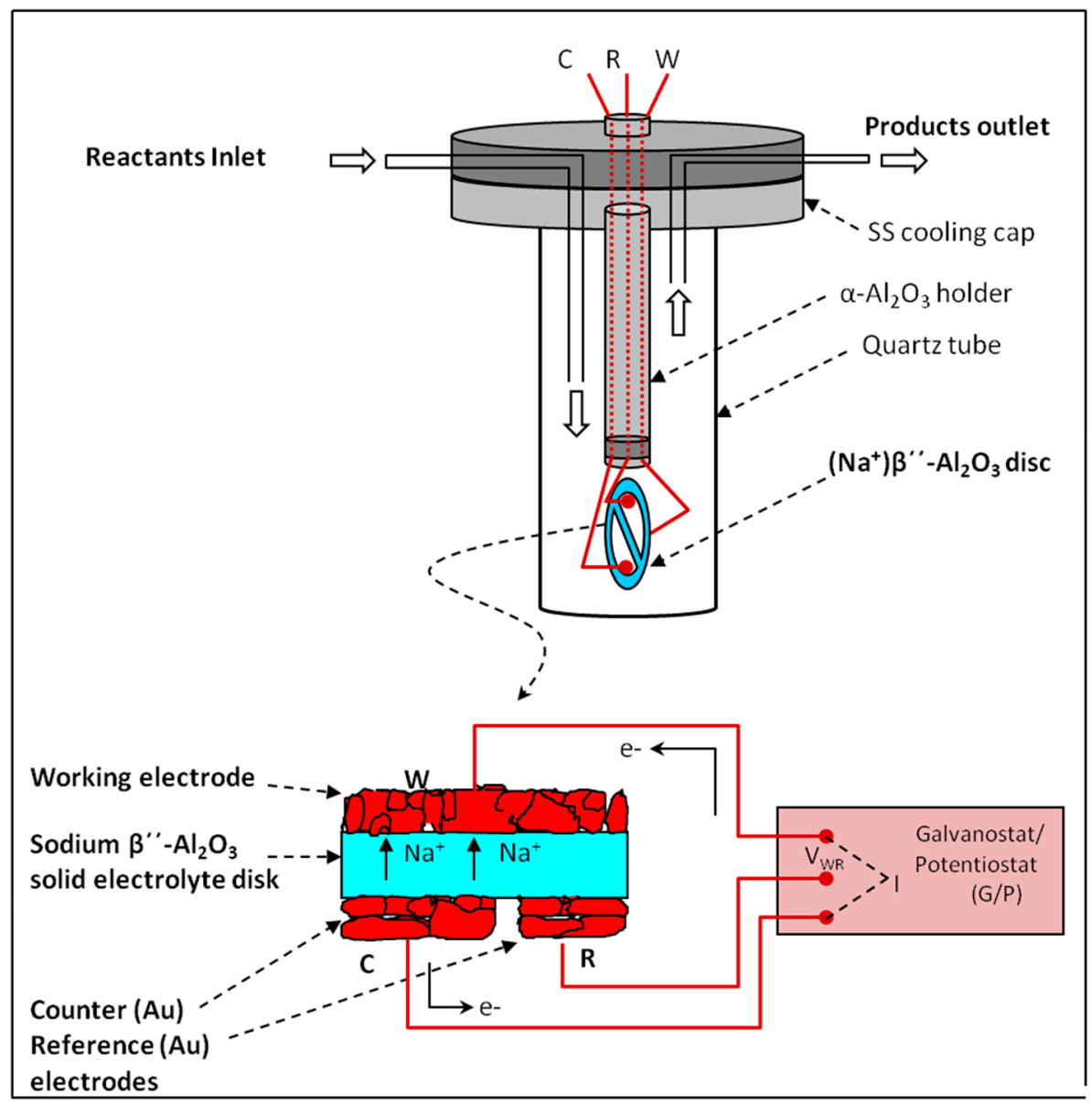

Figure 2. The single pellet reactor configuration for electrochemical promotion studies [12].

2.1.1. Operation Modes of the Electrochemical Promotion of Catalysis (EPOC)

(i) Galvanostatic transient operation:

One can use the galvanostatic transient mode of EPOC operation, described in detail in ref. [16], in order to be able to calculate the coverage, $\theta$, of the promoting species (electrochemically supplied) on the catalyst surface as a function of time. Briefly, transient galvanostatic operation concerns the application of a constant current, $I$, between the catalyst and counter electrodes via the galvanostat. In cells of the type described by the formula (1), imposition of a constant negative current corresponds to a constant flux of alkali cations to the catalyst surface at a rate equal $I / F$ (in moles of alkali/s).

The obtained alkali coverage, $\theta_{\text {Alk }}$, can therefore be calculated from Faraday's law $[6,16]$,

$$
\theta_{\text {Alk }}(\%)=100 \cdot\left(-I t / F N_{\mathrm{o}}\right)
$$

where, $t$ is the time of current $(I)$ application, $F$ is the Faraday's constant and $N_{\mathrm{o}}$ is the number of catalyst active sites independently measured via surface titration. Recording the metal-solid electrolyte polarization transient during the galvanostatic experiment that is, the time variation of catalyst potential by means of a reference electrode, $V_{W R}$ (Figure 1), this permits establishment of the relationship $\theta_{\text {Alk }}\left(V_{\text {WR }}\right)$ between alkali coverage and catalyst potential $V_{W R}$ (Figure 3).

This relationship is in general dependent on gaseous composition but this dependence is relatively weak because the catalyst work function $e \Phi$ varies according to $[6,7,11]$ :

$$
\mathrm{e} \Delta \mathrm{V}_{\mathrm{WR}}=\Delta(e \Phi)
$$


and is determined primarily by the coverage of alkali, due to the large dipole moment of alkalis on the Pt-group metal surfaces.

Galvanostatic operation concerns a continuous supply and accumulation of alkali on the catalyst surface (Equation (2)). Current interruption at a desired alkali coverage can then provide an optimally alkali-promoted catalyst surface. Alkali species are not typically consumed during the catalytic reaction, which allows working under stable reaction conditions. Hence, the promotional effect induced by the alkali coverage remains practically constant, even after the interruption of the applied current.

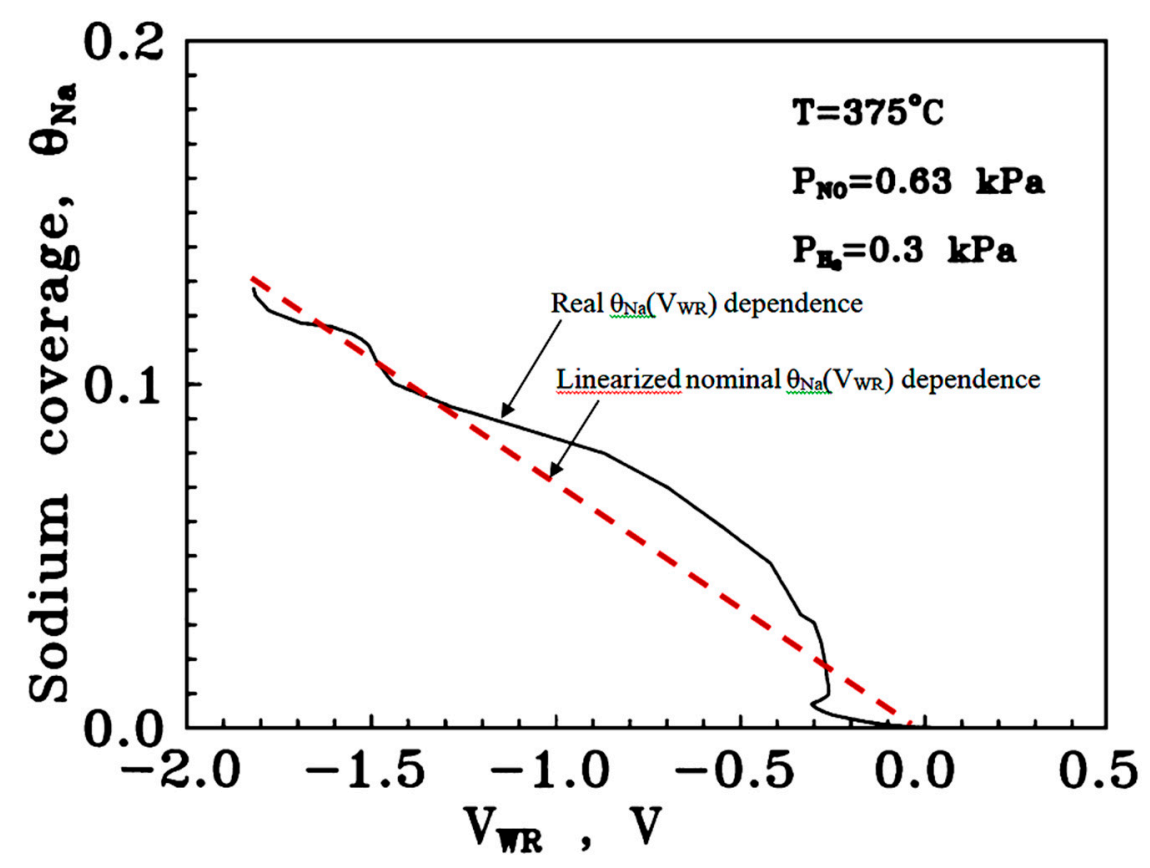

Figure 3. Dependence of alkali coverage on catalyst potential $V_{W R}$ under certain reaction conditions (Reproduced with permission from Ref. [19]. Copyright 1997, Elsevier).

It is worth noting that galvanostatic EPOC operation provides a rapid method for assessing the response of the reaction rate to promoter coverage (Figure 4); it consequently offers a very quick and easy way to find, at any set of conditions, the optimal promoter loading. This information could then be used for the direct design of optimally promoted conventional catalysts formulations for practical applications (Figure 4) [21].

(ii) Potentiostatic operation (a steady-state mode of operation):

The potentiostatic mode of EPOC operation corresponds to catalyst operation under the imposition of a constant catalyst polarization $\left(\mathrm{V}_{\mathrm{WR}}\right)$ via the potentiostat. This is a steady-state mode of operation: since the desired catalyst potential $V_{W R}$ is imposed via the potentiostat, a very rapid transfer of the appropriate amount of alkali cations to the catalyst surface takes place, which supplies the required amount of alkali in order to develop and stabilize the externally imposed polarization value $V_{W R}$; then the current is sharply vanished, asymptotically approaching the zero value.

Since the $\theta_{\text {Alk }}\left(V_{\mathrm{WR}}\right)$ relationship between alkali coverage and catalyst potential can be obtained through a galvanostatic transient conducted at the desired reaction conditions (as described in (i); e.g., Figure 3), the potentiostatic mode of operation is more suitable and commonly used in EPOC studies. It allows to work under steady-state conditions at several constant catalyst potentials, that is, at several constant coverages of the promoter. The steady-state reaction rate response on promoted catalyst surfaces, upon varying of the other reaction parameters (e.g., temperature, reactants' composition, etc.) can then be studied (e.g., [6,7]). 


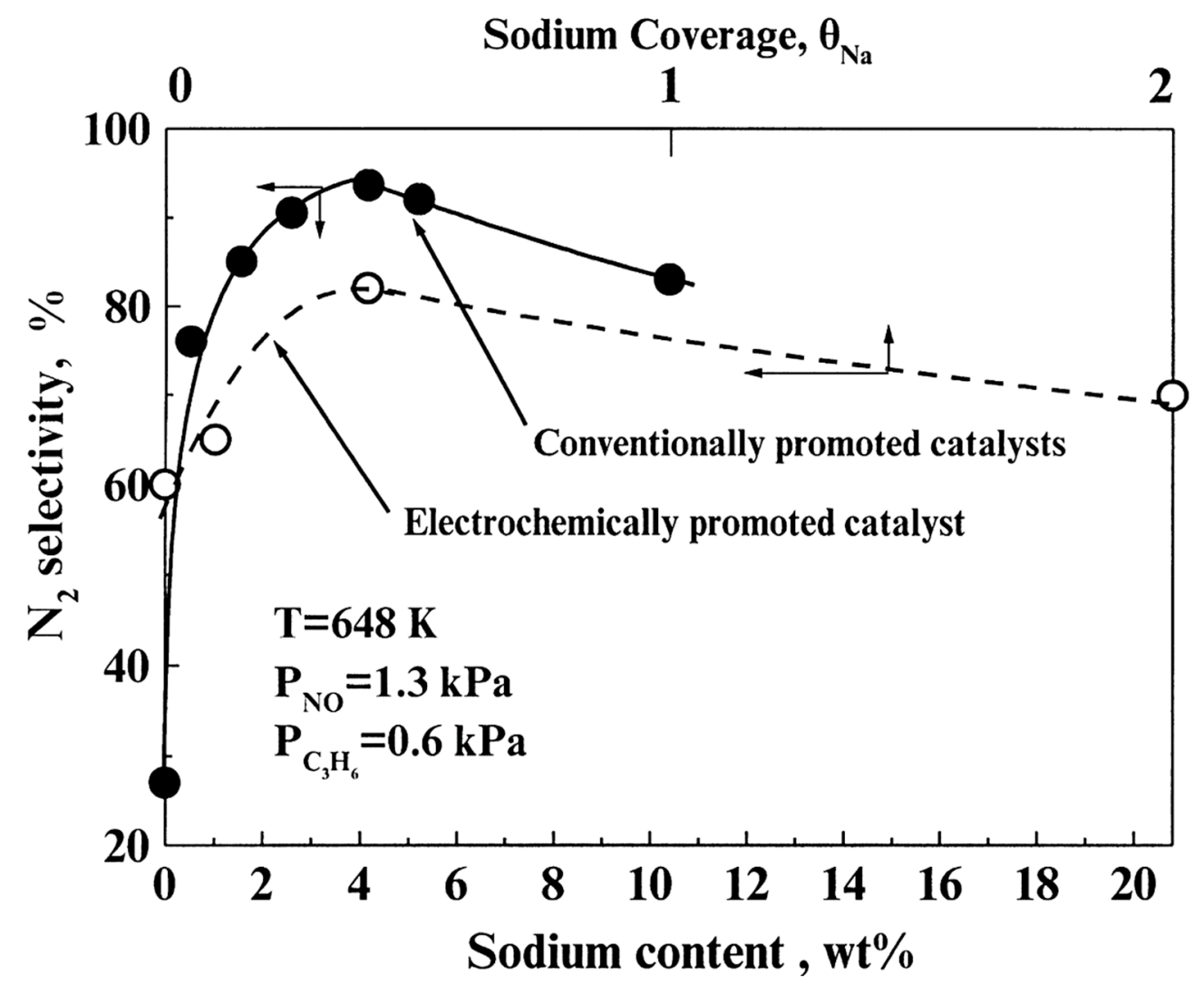

Figure 4. Comparison of electrochemically promoted (EPOC) and conventionally promoted (CCP) $\mathrm{Pt}$ with respect to $\mathrm{N}_{2}$-selectivity under the $\mathrm{NO}+\mathrm{C}_{3} \mathrm{H}_{6}$ reaction at $\mathrm{T}=375{ }^{\circ} \mathrm{C}$ and $[\mathrm{NO}]=1.3 \%$, $\left[\mathrm{C}_{3} \mathrm{H}_{6}\right]=0.6 \%$ feed. Similar well-correlated dependences of the variation of $\mathrm{N}_{2}$-selectivity on nominal sodium coverage $\left(\theta_{\mathrm{Na}}\right.$, upper abscissa) were obtained by the two methods of promotion (EPOC and $\mathrm{CCP}$ ) applied. EPOC was performed in a $\mathrm{Pt} /(\mathrm{Na}) \beta^{\prime \prime} \mathrm{Al}_{2} \mathrm{O}_{3} / \mathrm{Au}$ galvanic cell (Reprinted with permission from Ref. [22]. Copyright 2000, Elsevier).

\subsubsection{Certain Characteristics of EPOC Concept:}

(i) Reversibility of the electrochemically imposed promotional phenomena:

By reversing the direction of the applied current in the galvanic cell represented in Figure 1 or even by setting the potential value that corresponds to an alkali-free catalyst surface (Figure 3), the catalyst restores its initial un-promoted intrinsic properties. In other words, the electrochemically imposed promotional phenomena are totally reversible; EPOC provides an in situ, controlled and reversible way of catalyst promotion [6,7].

(ii) EPOC can be used as a fast probe for the optimal promoter loading determination:

Inter alia, EPOC can be successfully used as an effective research tool for evaluating the influence of a candidate promoter to a catalytic system and at the same time for determining the optimal promoter loading (coverage) at any reaction conditions of our interest. After the understanding that electrochemical and conventional promotions in catalysis, EPOC and CCP, are subjected to the same physicochemical rules (this has been proved both experimentally $[21,22]$ and theoretically $[23,24]$ ), the findings and knowledge obtained by the application of the electrochemical promotion can be successfully applied for the design of effective conventional catalyst formulations for practical applications $[21,22,25]$. This strategy enabled us to design novel catalyst formulations extremely active and selective in emission control catalysis, for example, optimally alkali-promoted noble metal catalysts [21]. 


\subsection{Conventional Catalyst Formulations. The Conventional Catalysts Promotion (CCP) Method}

The wet impregnation method was used in most cases for the production of conventional type (i.e., highly dispersed on large surface area carriers), alkali-promoted noble metal catalysts. Typical carriers used were $\gamma-\mathrm{Al}_{2} \mathrm{O}_{3}, \mathrm{SnO}_{2}$, yttria stabilized zirconia (YSZ) and rare earth oxides (REOs: $\mathrm{La}_{2} \mathrm{O}_{3}, \mathrm{CeO}_{2}$ ) modified $\gamma-\mathrm{Al}_{2} \mathrm{O}_{3}$. The preparation of the conventional promoted catalysts was performed either by two subsequent impregnation steps (where the noble metal was first deposited, followed by that of the promoter) or by simultaneous, one-step impregnation, in a solution containing both the noble metal and the promoter precursors, typically nitrate but also chloride salts). When using only nitrate precursors, pre-treatment procedures typically involve a high temperature (ca. 500-600 ${ }^{\circ} \mathrm{C}$ ) treatment step in air for the decomposition of the nitrates (active phase and promoter) and a subsequent treatment of the resulted catalysts under reaction conditions (i.e., under the studied reaction) for several hours or days in order to ensure stable operation. On the other hand, when a chloride precursor is used, pre-treatment in $\mathrm{H}_{2}$ flow at temperatures typically $400-450{ }^{\circ} \mathrm{C}$ for several hours $(>2 \mathrm{~h}$ ) is applied as a first step for the precursor decomposition and the removal of the residual chlorine (e.g., $[14,15])$; the inhibitory behaviour of the latter on the reactions related to emissions control catalysis is well known. Then, for performance stabilization purposes, operation at certain reaction conditions is applied, as well $[14,15]$.

\subsubsection{Estimation of the Promoter Coverage}

The coverage of the promoter species on the active catalyst surface is a significant factor not only for ranking but also for better understanding its promoting effects. Its knowledge is also useful for comparison purposes between electrochemically and conventionally promoted catalysts. For the former case (EPOC) we have already shown (Equation (2)) that the coverage of the alkali promoter can be directly estimated via the Faraday law applied to the data of a galvanostatic transient. In the latter case (CCP), a "nominal" percentage surface coverage of the alkali promoter $\left(\theta_{\text {Alk }}\right)$ could be calculated from the alkali $\mathrm{wt} \%$ content of the catalyst (e.g., [14,21]) by the assumption that all the promoter is present at the surface and distributed uniformly over the entire available area (noble metal + support), without any incorporation into the bulk and that an one-to-one correlation between alkali adatoms and active metal sites exists. Hence, the following equation can be used:

$$
\theta_{\text {Alk }}(\%)=(w t \% \text { of Alkali on the catalyst }) \cdot\left(N_{A V} / M_{\mathrm{Alk}} \cdot A \cdot d\right)
$$

where $N_{A V}$ is the Avogadro number, $M_{\text {Alk }}$ is the molecular weight of alkali used, $A$ is the BET catalyst surface area $\left(\mathrm{m}^{2} / \mathrm{g}\right)$ and $d$ is the surface density (atoms $/ \mathrm{m}^{2}$ ) of the active metal (PGM) (e.g., $d_{P t}=1.53 \times 10^{19}, d_{P d}=1.27 \times 10^{19}, d_{R h}=1.33 \times 10^{19}$ for $\{111\}$ crystallites). Considering $d$ in Equation (4) as the surface density of the alkali adatom used (i.e., $8.84 \times 10^{19}, 3.314 \times 10^{19}, 1.8 \times 10^{19}, 1.115 \times 10^{19}$ or $1.45 \times 10^{19}$ for $\mathrm{Li}, \mathrm{Na}, \mathrm{K}, \mathrm{Cs}$ or $\mathrm{Rb}$, respectively; values calculated on the basis of the alkali ionic radius), one can probably be led to a better estimation of the nominal alkali coverage [22,25]. In any case and since the issues about the alkali distribution (preference between active metal or support surface, formation of 2D and/or 3D aggregates) are not clear yet, it is apparent that Equation (4) leads to a quite rough estimation of alkali coverage, which however, in the absence of more rigorous estimations or experimental measurements, can be of some interest and applicable as a first approximation upon comparing the EPOC and CCP methods of promotion on a catalytic system (e.g., [22,25]).

The fixed bed, single pass, quartz (or stainless steel) tube reactor configuration is typically used for testing the conventional type catalysts (in the form of powder, small particle clusters or even structured honeycomb monolithic configurations) at the desired reactions. On-line gas chromatography, on-line mass spectroscopy and continuous $\mathrm{NO}_{\mathrm{x}}$ chemiluminescence's analysis were used for the analysis of the influent and effluent reactor streams in most studies. 


\subsubsection{EPOC and CCP Comparison Issues}

In order to have a solid basis for comparison between electrochemically promoted or conventional promoted catalysts, the rate enhancement ratio $(\rho)$, is introduced in both cases, defined as:

$$
\rho=\mathrm{r}_{\mathrm{x}} / \mathrm{r}_{\mathrm{O}} \quad(\mathrm{x}=\mathrm{EPOC} \text { or CCP })
$$

$r_{o}$ is the unpromoted rate and $r_{x}$ is the promoted by alkali rate, where the alkali species are either supplied electrochemically $(\mathrm{x}=\mathrm{EPOC})$ or conventionally $(\mathrm{x}=\mathrm{CCP}) . \rho$ values as high as $420(42,000 \%$ rate increase) have been reported for some important emissions control catalytic systems (e.g., $\mathrm{NO}+\mathrm{C}_{3} \mathrm{H}_{6} / \mathrm{Pt}$ ) by means of alkali promotion. It must be emphasized here that in literature studies (either EPOC or CCP) involving $\rho$ values estimation, particular attention was devoted in order the catalytic activity data to be acquired in the intrinsic kinetic regime, not influenced by mass transfer limitations (i.e., under low conversions, no limiting reactant, differential reactor operation, small catalyst particles, etc.)

In the case of EPOC an additional parameter, the Faradaic efficiency $(\Lambda)$ is also introduced [6], which can describe the magnitude of promotion; however, this has no meaning in CCP studies:

$$
\Lambda=\left(\mathrm{r}_{\mathrm{EPOC}}-\mathrm{r}_{\mathrm{o}}\right) /(\mathrm{I} / z \mathrm{~F})=\Delta \mathrm{r} /(\mathrm{I} / z \mathrm{~F})
$$

where $F$ is the Faradaic constant and $I$ is the current. The term $I / z F$ ( $z$ is the promoting ion charge; $z=+1$ in the case of alkali promotion) corresponds to the rate of promoting ions supplied electrochemically to the catalyst surface according to the Faraday's law.

Another useful parameter to quantify of the magnitude of the EPOC is the promotion index $\operatorname{Pi}[16,26]$ :

$$
P i=\left(\mathrm{r}_{\mathrm{EPOC}}-\mathrm{r}_{\mathrm{o}}\right) / \Delta \theta_{\mathrm{i}}
$$

where $\Delta \theta_{\mathrm{i}}$ is the coverage of the promoting species such as $\mathrm{Na}^{+}$.

\section{Results and Discussion}

\subsection{Promotion of Simple, "Model" Reactions}

Literature studies concerning "model" (i.e., simple) reactions, catalysed by Pt-group metals under electropositive promotion by alkalis or alkaline earths, conducted either by EPOC or CCP, are listed in Table 1 and discussed below.

\subsubsection{CO Oxidation}

Several publications concern the promotion of the PGMs-catalysed CO oxidation by alkalis. Significant promotional effects have been achieved either on thin metal film electrocatalysts interfaced with an alkali-contacting solid electrolyte (EPOC), playing the role of in situ source of alkali cations or on conventional type highly dispersed catalysts dosed with several amounts of alkali promoter (CCP). However, the promoting phenomena were found to be strongly depended on the $\mathrm{CO} / \mathrm{O}_{2}$ gas phase composition and on the alkali loading of the catalyst.

In particular, Yentekakis et al. [16] using the continuous flow, well-mixed, single-pellet reactor described in Figure 2 have shown that the rate of $\mathrm{CO}$ oxidation can be markedly enhanced via EPOC by up to $600 \%$ (at $\mathrm{T}=350{ }^{\circ} \mathrm{C}$ ) under $\mathrm{CO}$-rich conditions (i.e., at conditions where $\mathrm{CO}$ oxidation kinetics obey negative order in $\mathrm{CO}$, positive order in $\mathrm{O}_{2}$ ) over a Pt film electrocatalyst interfaced with a $\mathrm{Na}^{+}$-conducting $\beta^{\prime \prime} \mathrm{Al}_{2} \mathrm{O}_{3}$ solid electrolyte (Table 1 ). Those rate enhancements were achieved at sodium coverages on $\mathrm{Pt}$ surface of about $2-4 \%$, while higher sodium coverages were found to depress the catalyst activity, thus leading to a "volcano" type behaviour upon increasing the coverage of the promoting species (Figure 5, curve a). However, at $\mathrm{O}_{2}$-rich conditions (i.e., when the rate is of positive order in $\mathrm{CO}$ ) only poisoning phenomena occurred upon increasing Na coverage on the 
catalyst surface (Figure 5 curve b). According to the rules of catalyst promotion, Na promoters modify the chemisorptive properties of $\mathrm{CO}$ and $\mathrm{O}_{2}$ reactants on $\mathrm{Pt}$ active sites. At $\mathrm{CO}$-rich conditions and for Na coverages up to $\sim 4 \%$, the promotional effect was attributed to a Na-induced enhancement in oxygen chemisorption as a result of a strengthening of the $\mathrm{Pt}-\mathrm{O}$ bond. The rate poisoning behaviour at higher Na coverages was attributed to active sites blocking phenomena due to the formation of a $\mathrm{CO}-\mathrm{Na}-\mathrm{Pt}$ surface complex.

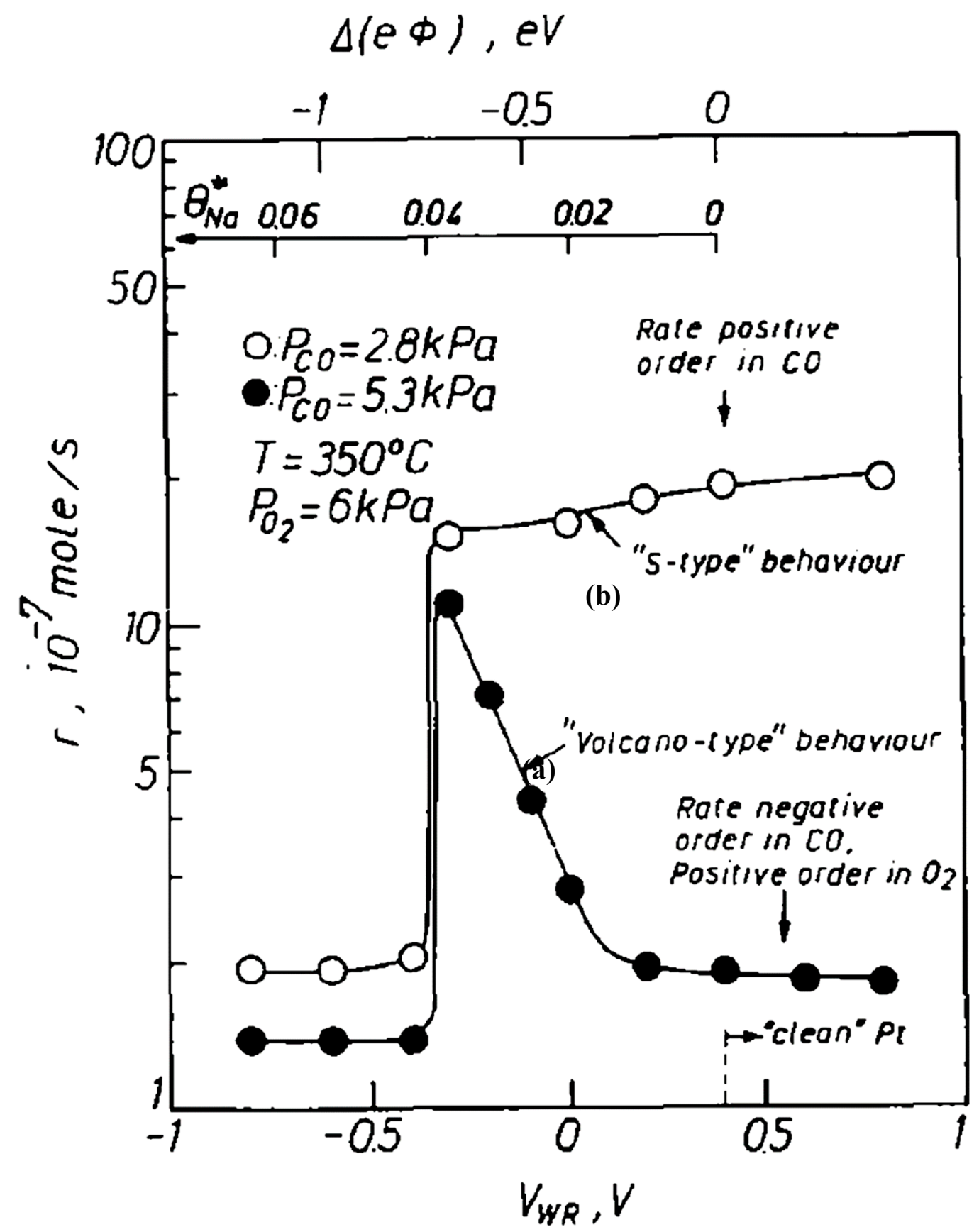

Figure 5. Effect of $\mathrm{Na}$ coverage $\theta_{\mathrm{Na}}$ on the rate of $\mathrm{CO}$ oxidation at oxygen lean $\left(\mathrm{a}: \mathrm{T}=350{ }^{\circ} \mathrm{C},\left[\mathrm{O}_{2}\right]=6 \%\right.$, $[\mathrm{CO}]=5.3 \%$; filled symbols) and at oxygen rich $\left((\mathbf{b}): \mathrm{T}=350{ }^{\circ} \mathrm{C},\left[\mathrm{O}_{2}\right]=6 \%,[\mathrm{CO}]=2.8 \%\right.$; open symbols) conditions. The volcano type behaviour upon increased Na coverage is obvious in case (a). Data was acquired in a Pt/(Na) $\beta^{\prime \prime} \mathrm{Al}_{2} \mathrm{O}_{3} / \mathrm{Au}$ galvanic cell (Reprinted with permission from Ref. [16]; Copyright 1994, Elsevier). 
Another EPOC study was reported by De Lucas-Consuegra et al. [27] on the effect of electrochemically imposed potassium $(\mathrm{K})$ on the Pt-catalysed CO oxidation at $200-350{ }^{\circ} \mathrm{C}$. Rate enhancement ratios of about $\rho=11(1100 \%)$ at $\mathrm{T}=278^{\circ} \mathrm{C}$ and light-off temperature decreases by $\sim 40^{\circ} \mathrm{C}$ were achieved at equimolar reactant composition, $[\mathrm{CO}]=\left[\mathrm{O}_{2}\right]=5000 \mathrm{ppm}$ (Figure 6 and Table 1).

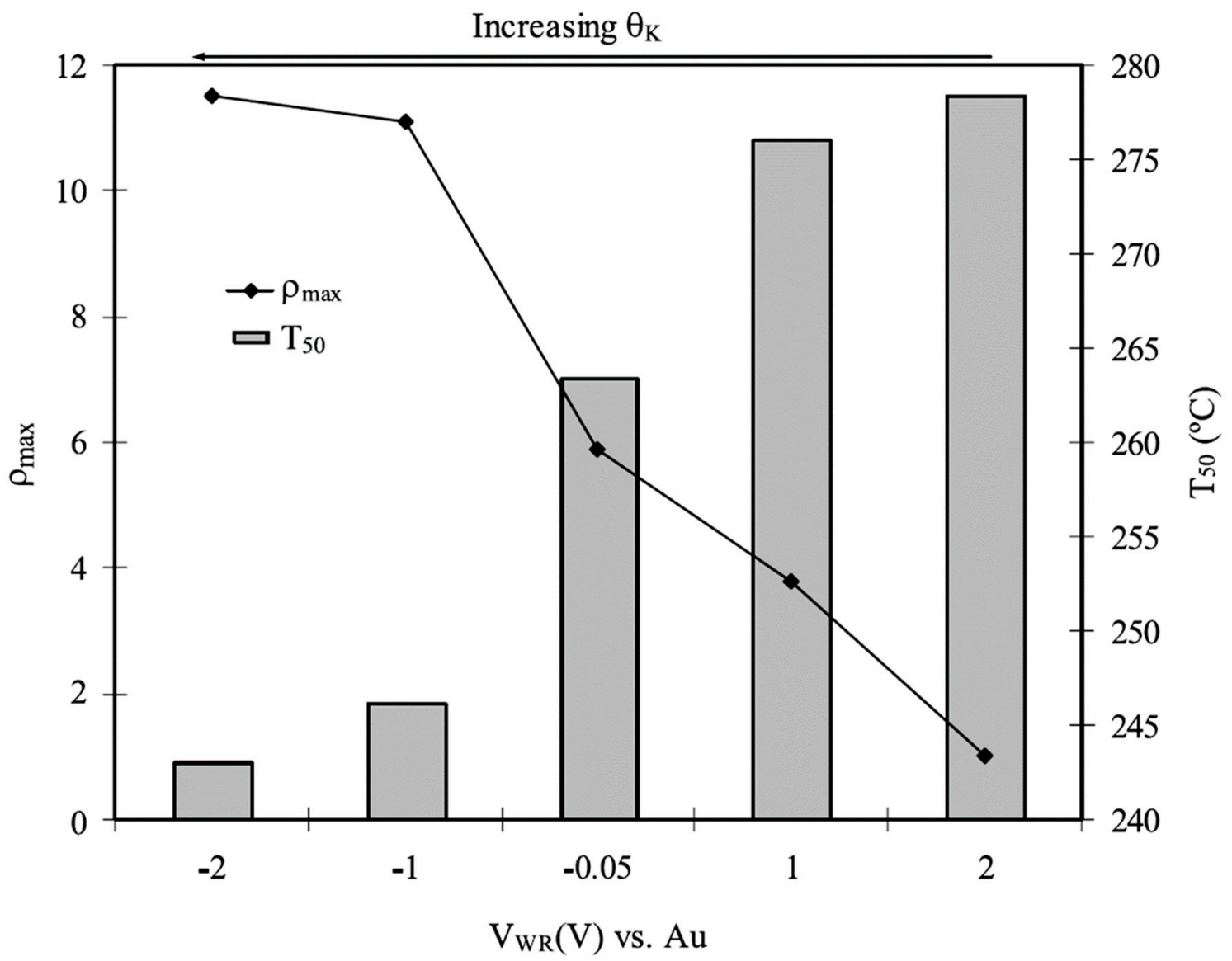

Figure 6. Effect of catalyst overpotential (VWR) on the maximum rate enhancement ratio $\left(\rho_{\max }\right)$ and on $\mathrm{T}_{50}$ of $\mathrm{CO}$ oxidation on Pt. Conditions: $[\mathrm{CO}]=\left[\mathrm{O}_{2}\right]=0.5 \%$ He balance, $\mathrm{F}_{\mathrm{t}}=108 \mathrm{~cm}^{3} / \mathrm{min}$. Data was acquired in a $\mathrm{Pt} /(\mathrm{K}) \beta^{\prime \prime} \mathrm{Al}_{2} \mathrm{O}_{3} / \mathrm{Au}$ galvanic cell. (Reprinted with permission from Ref. [27]; Copyright 2008, Elsevier).

The maximum promotional effect was found under the application of $-2 \mathrm{~V}$; the appropriate parameters necessary for the estimation of the $\mathrm{K}$ coverage corresponding to this catalyst polarization are not available. The reversible promotional phenomena were attributed to the formation and decomposition of potassium compounds on the Pt surface (probably potassium carbonates and/or oxides) that enhanced the adsorption of oxygen at the expense of $\mathrm{CO}$ on a surface predominately covered by $\mathrm{CO}$ under unpromoted conditions in the reaction temperature range studied.

Regarding CCP studies, $\mathrm{CO}$ oxidation activity enhancements were also reported by Mirkelamoglu and Karakas [28,29] over conventional type $0.1 \mathrm{wt} \%$ Na-promoted $1 \mathrm{wt} \% \mathrm{Pd} / \mathrm{SnO}_{2}$ catalyst tested at two different $[\mathrm{CO}] /[\mathrm{O}]$ ratios, 1.25 and 0.5. The authors found that in the case of CO-rich gas composition $([\mathrm{CO}] /[\mathrm{O}]=1.25)$, $\mathrm{Pd}$ can be up to 2.6 -fold times $(260 \%)$ more active on CO oxidation at $150{ }^{\circ} \mathrm{C}$ (Table 1 ), while non or moderate promotional effects were observed at $\mathrm{O}_{2}$-rich conditions $([\mathrm{CO}] /[\mathrm{O}]=0.5)$. A surface segregation of $\mathrm{Pd}$ atoms increasing the reactive sites for $\mathrm{CO}$ oxidation, together with the formation of super-oxide species observed over $\mathrm{Na}-\mathrm{PdO} / \mathrm{SnO}_{2}$ were considered to be the origin of the observed promotional effects on the Na-dosed catalyst [29].

The effect of alkali oxide additives $\left(\mathrm{Na}_{2} \mathrm{O}, \mathrm{K}_{2} \mathrm{O}\right)$ on the alumina support of $\mathrm{Pt} / \mathrm{Al}_{2} \mathrm{O}_{3}$ catalysts on $\mathrm{CO}$ oxidation was investigated by Lee and $\mathrm{Chen}$ [30]. They concluded that the addition of alkalis 
on $\mathrm{Al}_{2} \mathrm{O}_{3}$ influences the basicity of the catalyst, which in turn results to higher oxidation activities. Higher promotional effect was achieved by potassium, which resulted in a decrease of CO light-off temperature by $90{ }^{\circ} \mathrm{C}$ under $\mathrm{CO} / \mathrm{O}_{2}$ stoichiometric conditions. The study, however, was performed under simulated two-stroke motorcycle emissions (involving $\mathrm{C}_{3} \mathrm{H}_{6}, \mathrm{H}_{2}, \mathrm{CO}_{2}$ and $\mathrm{H}_{2} \mathrm{O}$ in the feed, besides $\mathrm{CO}$ and $\mathrm{O}_{2}$ ) at the stoichiometric point and oxygen-deficient environments. Therefore, this work will be further analysed in the proper Section 3.2.1.

The influence of alkaline earths on $\mathrm{CO}$ oxidation activity was also investigated over Pd catalysts supported on Ba-modified $\gamma-\mathrm{Al}_{2} \mathrm{O}_{3}$ or $\mathrm{CeO}_{2}-\mathrm{ZrO}_{2}$ carriers by Tanikawa and Egawa [31]. They found that the activity of $\mathrm{Pd} / \gamma-\mathrm{Al}_{2} \mathrm{O}_{3}$ catalyst can be significantly improved by increasing the Ba promoter loading; an amount of $10-15 \mathrm{wt} \%$ Ba decreases the light-off temperature by $\sim 45{ }^{\circ} \mathrm{C}$ compared to the un-modified catalyst (Table 1). However, an adverse effect upon Ba addition was observed for $\mathrm{Pd} / \mathrm{CeO}_{2}-\mathrm{ZrO}_{2}$ catalysts; an amount of $10 \mathrm{wt} \%$ Ba leads to an increase of light-off temperature by $\sim 100{ }^{\circ} \mathrm{C}$. The pronounced effect of $\mathrm{Ba}$ over $\mathrm{Pd} / \gamma-\mathrm{Al}_{2} \mathrm{O}_{3}$ catalysts was ascribed to the weakening of $\mathrm{CO}$ adsorption strength, whereas its inhibiting role over $\mathrm{Pd} / \mathrm{CZ}$ catalysts was attributed to the suppression of Pd interaction with ceria-zirconia support.

In addition, the pronounced effect of electropositive promoters on $\mathrm{CO}$ preferential oxidation (PROX) under $\mathrm{H}_{2}$-rich conditions has been recently demonstrated [32-41]. Minemura et al. [32,33] showed that the addition of alkalis ( $\mathrm{Li}, \mathrm{Na}, \mathrm{K}, \mathrm{Rb}$ and $\mathrm{Cs}$ ) in a $2 \mathrm{wt} \% \mathrm{Pt} / \gamma-\mathrm{Al}_{2} \mathrm{O}_{3}$ catalyst results in very significant promotional effects on the selective oxidation of $\mathrm{CO}$ under $\mathrm{H}_{2}$-rich environments (Table 1). The promotional effects followed "volcano" type behaviour upon increasing alkali loading, thus providing an optimal loading for each alkali; a 10-15 alkali/Pt loading ratio was found to optimize the promotional effects of $\mathrm{Na}$ and $\mathrm{K}$, while the optimal alkali/Pt ratios were 3 and 5 for $\mathrm{Cs}$ and $\mathrm{Rb}$, respectively. For a constant alkali/Pt loading equal to 3 , the order on the promoting effect on $\mathrm{CO}$ conversion (and TOFs) was found to be $\mathrm{Cs}>\mathrm{Rb}>\mathrm{K}>\mathrm{Na}>\mathrm{Li} \sim$ alkali-free $\mathrm{Pt}$, while the order of the selectivity to $\mathrm{CO}_{2}$ was $\mathrm{K}>\mathrm{Rb}, \mathrm{Na}>\mathrm{Cs}>\mathrm{Li}$. At higher alkali loadings (alkali $/ \mathrm{Pt}=10$ ), the order of the turnover frequency rates of $\mathrm{CO}$ oxidation were $\mathrm{K}>\mathrm{Na}>\mathrm{Rb}>\mathrm{Cs} \sim \mathrm{Li}>$ alkali-free $\mathrm{Pt}$, with a similar order for the selectivity towards $\mathrm{CO}_{2}$. The changes in the order of the activity of the catalysts were due to over-promotion, that is, for some alkalis (e.g., $\mathrm{Rb}$ and $\mathrm{Cs}$ ) their optimal loading was exceeded under the conditions used. In these studies, turnover rate enhancement ratio values up to $\rho=10$ for the optimal K promotion at $\mathrm{T}=100^{\circ} \mathrm{C}$ [32] and even better (up to $\rho=20$ ) at $80^{\circ} \mathrm{C}$ [33] were achieved. Further studies by the research group, focused on the optimal promoter $(\mathrm{K})$ when applying different supports $\left(\mathrm{Al}_{2} \mathrm{O}_{3}, \mathrm{SiO}_{2}\right.$, $\mathrm{ZrO}_{2}, \mathrm{Nb}_{2} \mathrm{O}_{5}$ and $\mathrm{TiO}_{2}$ ) for the dispersion of $\mathrm{Pt}$, have shown that the most remarkable promoting effects are obtained on $\mathrm{Pt} / \gamma-\mathrm{Al}_{2} \mathrm{O}_{3}$ [34] (Table 1). Corroborative characterization studies by means of a variety of techniques, e.g., Transmission Electron Microscopy (TEM), Extended X-ray Absorption Fine Structure (EXAFS), X-ray Absorption Near Edge Structure (XANES), Fourier-Tranform Infrared Spectroscopy (FTIR), enable the authors to consistently interpret the promotion features [35,36]. FTIR spectroscopic evidences for a K-induced weakening in the strength of $\mathrm{CO}$ adsorption on $\mathrm{Pt}$ and drastic changes on the adsorption site of $\mathrm{CO}$ (bridge and three-fold hollow $\mathrm{CO}$ species) found on the $\mathrm{Pt}(10 \mathrm{wt} \% \mathrm{~K}) / \gamma-\mathrm{Al}_{2} \mathrm{O}_{3}$ catalyst were considered responsible for the observed promotional effects attributed to the change in the electronic state of K-modified platinum [35,36]. $\mathrm{OH}$ co-adsorbed species (originating form $\mathrm{H}_{2}$ and $\mathrm{O}_{2}$ interaction under PROX conditions) that promote the $\mathrm{CO}$ oxidation were found by in situ FTIR on the highly active $\mathrm{K}$-modified $\mathrm{Pt} / \gamma-\mathrm{Al}_{2} \mathrm{O}_{3}$ catalyst [36]. The inhibiting effects on PROX reaction under over-promotion conditions (beyond the optimal promoter loading) were attributed to aggregation of Pt metal particles caused by the larger amount of alkali metal used [36].

$\mathrm{CO}$ preferential oxidation was also found to be very pronounced over $\mathrm{Pt}$ clusters dispersed on alkali ( $\mathrm{Na}, \mathrm{Rb}$ or $\mathrm{Cs}$ )-modified $\mathrm{SiO}_{2}$ by Pedrero et al. [37]. Optimum promotional effects were obtained with $\mathrm{Cs}$ at a surface concentration of 1.6 atoms $/ \mathrm{nm}^{2}$; CO oxidation turnover rates (TOFs) more than one order of magnitude higher than those obtained on the un-promoted $\mathrm{Pt} / \mathrm{SiO}_{2}$ catalysts were recorded, which were accompanied by CO oxidation selectivity $>90 \%$ (Table 1 ). In accordance to the authors, the beneficial effect of alkalis can be interpreted based both on the electronic interactions between 
alkali atoms and metals and on the inhibition of spill over-mediated $\mathrm{H}_{2}$ oxidation pathways induced by alkalis.

The effect of Na promoter on CO PROX reaction was also investigated over bimetallic $\mathrm{PtCo} / \mathrm{Al}_{2} \mathrm{O}_{3}$ catalysts by Kwak et al. [38]. They found moderate promotion of PROX activity on monometallic $\mathrm{Pt}$ catalyst while substantial rate promotion on the bimetallic PtCo counterpart catalyst up to a sodium loading of $2.0 \mathrm{wt} \%$; the CO-PROX selectivity was not influenced in both cases (Table 1 ). They concluded that the formation of Na-O-Al bonds by incorporation of $\mathrm{Na}$ ions into the alumina lattice, that happens at low sodium content, suppresses the formation of the surface spinel cobalt species and promotes the formation of bimetallic Pt-Co species; at higher Na content (ca. $3 w t \%)$ bulk sodium particles on the catalyst surface interact with the active species inhibiting PROX activity.

On the other hand, a notable increase on both $\mathrm{CO}$ conversion and $\mathrm{CO}_{2}$ selectivity under PROX conditions was attained with $\mathrm{Mg}$-promoter over $\mathrm{Pt} / \mathrm{Al}_{2} \mathrm{O}_{3}$ catalysts by $\mathrm{Cho}$ et al. [39] (Table 1). The maximum values of $\mathrm{CO}$ conversion and $\mathrm{CO}_{2}$ selectivity for $\mathrm{Pt}-\mathrm{Mg} / \mathrm{Al}_{2} \mathrm{O}_{3}$ catalysts were 93.1 and $62 \%$, respectively, at $170{ }^{\circ} \mathrm{C}$, compared to 70.2 and $46.8 \%$ at $200{ }^{\circ} \mathrm{C}$ over the un-promoted $\mathrm{Pt} / \mathrm{Al}_{2} \mathrm{O}_{3}$ catalysts. The effect of $\mathrm{CO}_{2}$ and $\mathrm{H}_{2} \mathrm{O}$ in the feed was also studied in this work under PROX conditions, as well as the $\mathrm{CO}$ oxidation reaction in the absence of excess $\mathrm{H}_{2}$ under $\mathrm{Mg}$-promotion. The superior performance of Mg-modified catalysts was attributed to an increase in Pt electron density, as well as to an increase of hydroxyl groups on catalyst surface.

Finally, de Lucas-Consuegra and co-workers [40] demonstrated the pronounced effect of electropositive modifiers $\left(\mathrm{K}^{+}\right.$ions) on the preferential oxidation of $\mathrm{CO}$ via EPOC by the use of a Pt/K $\mathrm{K}^{+}$-conducting- $\beta \mathrm{Al}_{2} \mathrm{O}_{3} / \mathrm{Au}$ galvanic cell. At a $195{ }^{\circ} \mathrm{C}$ and a feed composition of $\mathrm{CO} / \mathrm{O}_{2} / \mathrm{H}_{2}=0.4 \% / 0.2 \% / 16 \%$, the authors found up to $\rho=1.3$ rate enhancements, achievable at a potassium coverage of $\theta_{\mathrm{K}} \sim 2-4 \%$. A concomitant increase in $\mathrm{CO}_{2}$ selectivity of $\sim 10 \%$ was recorded as well (Table 1). The effect of the alkali on the chemisorptive bonds of $\mathrm{CO}, \mathrm{H}$ and $\mathrm{O}$ on $\mathrm{Pt}$ surface was considered to be the origin of the observed promotional phenomena.

For more information, a short review has been recently published regarding the promotional effect of alkali promoters (CCP) on PGMs (Pt, Ru and Ir)-catalysed CO PROX reaction [41].

A comparative overview of the literature findings included in Section 3.1.1 and in Table 1 leads to the following general remarks: Among PGMs only Pt and Pd were investigated so far for CO oxidation under electropositive promotion (by alkalis or alkaline earths). No studies exist that were performed at similar conditions using both EPOC and CCP methods, preventing us from making a direct one-to-one comparison of the outputs of the two methods. The general view is that alkalines efficiently promote the $\mathrm{Pt}$ and $\mathrm{Pd}$ catalysed $\mathrm{CO}$ oxidation only at conditions where the reaction rate is negative order in $\mathrm{CO}$, positive order in $\mathrm{O}_{2}$ (the so-called $\mathrm{CO}$-rich conditions at which $\mathrm{CO}$ coverage predominates on the catalyst surface; not necessary at $\mathrm{CO} / \mathrm{O}_{2}>1$ ), while non, moderate or only poisoning was found under $\mathrm{O}_{2}$-rich conditions. Even in the former case, the promotion follows volcano type behaviour upon increasing promoter loading, reversed to poisoning for high promoter loadings; optimal promoter loadings were typically low. The maximum rate enhancement ratios were reported for $\mathrm{Pt} / \mathrm{CO}+\mathrm{O}_{2}$ catalytic system under EPOC: $\rho=6$ with Na at $350{ }^{\circ} \mathrm{C}$ [16] and $\rho=11$ with $\mathrm{K}$ at $278^{\circ} \mathrm{C}$ [27].

Volcano-type promotion was the main feature of the electropositive promotion of PGMs under the preferential CO oxidation (PROX), as well. Moreover, for similar reaction and promoter loading conditions larger alkalis ( $\mathrm{Cs}, \mathrm{Rb}, \mathrm{K}$ ) offered superior promotion. For this reaction two studies exist that concern usage of the same promoter $(\mathrm{K})$ and active metal $(\mathrm{Pt})$, one performed using $\mathrm{CCP}$ the other EPOC. Although $\rho$ values obtained by CCP were significantly larger $(\rho=10$ [32-36]) than that obtained by EPOC $(\rho=1.3[40])$, the applied conditions were quite different, preventing us from making a creative comparison.

The alkaline-induced pronounced enhancement on oxygen adsorption compared to that of $\mathrm{CO}$ was a key argument in most of the aforementioned studies upon explaining their findings, whereas the formation of large surface alkali complexes was considered responsible for the rate poisoning at high alkali loadings. 
Table 1. Electropositive promotion of PGMs-catalysed $\mathrm{CO}$ oxidation $\left(\mathrm{CO}+\mathrm{O}_{2}\right)$ and Preferential CO oxidation $\left(\mathrm{PROX}: \mathrm{CO}+\mathrm{O}_{2}+\mathrm{excess} \mathrm{H}_{2}\right)$.

\begin{tabular}{|c|c|c|c|c|c|}
\hline Reactants & Catalyst, (promotion method applied) & Promoter & Reaction conditions & Promotion highlights and optimal achievements & Ref. \\
\hline $\mathrm{CO}, \mathrm{O}_{2}$ & $\begin{array}{l}\text { Pt-film over }(\mathrm{Na}) \beta^{\prime \prime} \mathrm{Al}_{2} \mathrm{O}_{3} \text { solid } \\
\text { electrolyte } \\
(\mathrm{EPOC})\end{array}$ & $\mathrm{Na}$ & $\begin{array}{c}\mathrm{T}=300-450{ }^{\circ} \mathrm{C} \\
{[\mathrm{CO}]=0-4 \%} \\
{\left[\mathrm{O}_{2}\right]=0-6 \%}\end{array}$ & 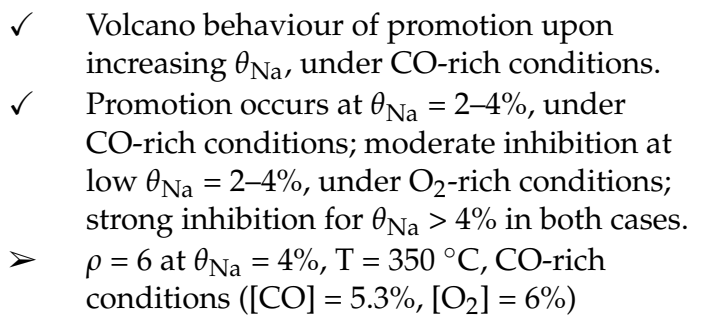 & [16] \\
\hline $\mathrm{CO}, \mathrm{O}_{2}$ & $\begin{array}{c}\text { Pt-film over }(\mathrm{K}) \beta^{\prime \prime} \mathrm{Al}_{2} \mathrm{O}_{3} \\
\text { (EPOC) }\end{array}$ & K & $\begin{array}{c}\mathrm{T}=200-350{ }^{\circ} \mathrm{C} \\
{[\mathrm{CO}]=\left[\mathrm{O}_{2}\right]=500 \mathrm{ppm}}\end{array}$ & $\begin{array}{l}\checkmark \quad \begin{array}{l}\text { Significant K-induced promotion, providing } \\
\text { a system proper for } \mathrm{LT} C \mathrm{CO} \text { oxidation. }\end{array} \\
>\quad \rho=11 \text { at } \mathrm{T}=278{ }^{\circ} \mathrm{C} \text { and } \Delta \mathrm{T}_{50}=-40{ }^{\circ} \mathrm{C} ;[\mathrm{CO}] \\
=\left[\mathrm{O}_{2}\right]=500 \mathrm{ppm}\end{array}$ & [27] \\
\hline $\mathrm{CO}, \mathrm{O}_{2}$ & $\begin{array}{c}1 \mathrm{wt} \% \mathrm{PdO} / \mathrm{SnO}_{2} \\
(\mathrm{CCP})\end{array}$ & $\mathrm{Na}$ & $\begin{array}{c}\mathrm{T}=150^{\circ} \mathrm{C} \\
{[\mathrm{CO}] /[\mathrm{O}]=1.25} \\
{[\mathrm{CO}] /[\mathrm{O}]=0.5} \\
([\mathrm{CO}]=2400 \mathrm{ppm}) \\
\text { Na-loading: } 0.1 \mathrm{wt} \%\end{array}$ & $\begin{array}{l}\checkmark \quad \begin{array}{l}\text { Significant promotion at CO-rich conditions; } \\
\text { more effective on pre-reduced catalysts }\end{array} \\
\text { Achievements on pre-oxidized catalysts: } \rho= \\
1.5, \Delta \mathrm{T}_{50}=-12^{\circ} \mathrm{C}(\text { at }[\mathrm{CO}] /[\mathrm{O}]=1.25) ; \rho= \\
0.66, \Delta \mathrm{T}_{50}=+4{ }^{\circ} \mathrm{C}(\text { at }[\mathrm{CO}] /[\mathrm{O}]=0.5) \\
>\quad \text { Achievements on pre-reduced catalysts: } \rho= \\
2.6, \Delta \mathrm{T}_{50}=-25^{\circ} \mathrm{C}(\text { at }[\mathrm{CO}] /[\mathrm{O}]=1.25) ; \rho= \\
1.3, \Delta \mathrm{T}_{50}=-8^{\circ} \mathrm{C}(\text { at }[\mathrm{CO}] /[\mathrm{O}]=0.5)\end{array}$ & $\begin{array}{l}{[28]} \\
{[29]}\end{array}$ \\
\hline $\mathrm{CO}, \mathrm{O}_{2}$ & $\begin{array}{c}1 \mathrm{wt} \% \mathrm{Pd} / \gamma-\mathrm{Al}_{2} \mathrm{O}_{3} \text { and } 1 \mathrm{wt} \% \mathrm{Pd} / \mathrm{CZ} \\
(\mathrm{CCP})\end{array}$ & $\mathrm{Ba}$ & $\begin{array}{c}\mathrm{T}=50-250{ }^{\circ} \mathrm{C} \\
{[\mathrm{CO}]=2.2 \%,\left[\mathrm{O}_{2}\right]=1.1 \%} \\
\text { Ba-loadings: } 0,1,5.5,10 \\
15 \mathrm{wt} \%\end{array}$ & 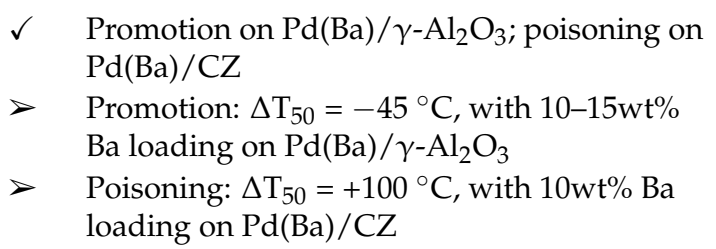 & {$[31]$} \\
\hline
\end{tabular}


Table 1. Cont

\begin{tabular}{|c|c|c|c|c|c|}
\hline Reactants & Catalyst, (promotion method applied) & Promoter & Reaction conditions & Promotion highlights and optimal achievements & Ref. \\
\hline $\begin{array}{l}\mathrm{CO}, \mathrm{O}_{2}, \mathrm{H}_{2} \\
\text { excess }\end{array}$ & $\begin{array}{c}2 \mathrm{wt} \% \mathrm{Pt} /\left(\gamma-\mathrm{Al}_{2} \mathrm{O}_{3}, \mathrm{SiO}_{2}, \mathrm{ZrO}_{2}, \mathrm{Nb}_{2} \mathrm{O}_{5}\right. \\
\left.\text { or } \mathrm{TiO}_{2}\right) \\
(\mathrm{CCP})\end{array}$ & $\mathrm{Li}, \mathrm{Na}, \mathrm{K}, \mathrm{Rb}, \mathrm{Cs}$ & $\begin{array}{c}\mathrm{T}=100-160^{\circ} \mathrm{C} \\
{[\mathrm{CO}]=\left[\mathrm{O}_{2}\right]=0.2 \%} \\
\text { Alkali loadings: } \mathrm{A} / \mathrm{Pt} \\
\text { molar ratio }=0-20\end{array}$ & $\begin{array}{l}\checkmark \quad \begin{array}{l}\text { Volcano-type promotion upon increasing } \\
\text { alkali loading. K was the superior promoter. }\end{array} \\
\checkmark \quad \begin{array}{l}\text { For } \mathrm{A} / \mathrm{Pt}<3 \text { the promoting effect of alkalis } \\
\text { followed the order: } \mathrm{Cs}>\mathrm{Rb}>\mathrm{K}>\mathrm{Na}>\mathrm{Li}\end{array} \\
\checkmark \quad \begin{array}{l}\text { For } \mathrm{A} / \mathrm{Pt}>5 \text { the promoting effect of alkalis } \\
\text { followed the order: } \mathrm{K}>\mathrm{Na}>\mathrm{Rb}>\mathrm{Cs}>\mathrm{Li}\end{array} \\
\checkmark \quad \begin{array}{l}\mathrm{An} \mathrm{A} / \mathrm{Pt}=10-15,3 \text { and } 5 \text { optimizes } \mathrm{Na} \text { or } \mathrm{K}, \\
\mathrm{Cs} \text { and } \mathrm{Rb} \text { promotion, respectively. }\end{array} \\
>\quad \begin{array}{l}\rho=10 \text { with } \mathrm{K}, \text { with a loading of } \mathrm{K} / \mathrm{Pt}=10 \\
\text { molar ratio }\end{array}\end{array}$ & $\begin{array}{l}{[32]} \\
{[33]} \\
{[34]} \\
{[35]} \\
{[36]}\end{array}$ \\
\hline $\begin{array}{l}\mathrm{CO}, \mathrm{O}_{2}, \mathrm{H}_{2} \\
\text { excess }\end{array}$ & $\begin{array}{c}1.6 \mathrm{wt} \% \mathrm{Pt} / \mathrm{SiO}_{2} \\
(\mathrm{CCP})\end{array}$ & $\mathrm{Na}, \mathrm{Rb}, \mathrm{Cs}$ & $\begin{array}{c}\mathrm{T}=110^{\circ} \mathrm{C} \\
{[\mathrm{CO}]=\left[\mathrm{O}_{2}\right]=1 \%,\left[\mathrm{H}_{2}\right]=} \\
70 \% \\
\text { Cs surface density }=0-6 \\
\text { atoms } / \mathrm{nm}^{2}\end{array}$ & $\begin{array}{l}\checkmark \quad \begin{array}{l}\text { Volcano-type promotion upon increasing } \\
\text { alkali loading. Cs was the superior promoter. }\end{array} \\
\checkmark \quad \begin{array}{l}\text { Promotion is maximized at a Cs loading }=1.6 \\
\text { Cs } / \mathrm{nm}^{2} \text { of catalyst surface. }\end{array} \\
>\quad \begin{array}{l}\rho=10 \text { and } \Delta \mathrm{S}_{\mathrm{CO}}=+30 \% \text { (from } 60 \% \rightarrow 90 \% \text { ) } \\
\text { with an } 1.6 \mathrm{Cs} / \mathrm{nm}^{2} \text { alkali surface density. }\end{array}\end{array}$ & [37] \\
\hline $\begin{array}{l}\mathrm{CO}, \mathrm{O}_{2}, \mathrm{H}_{2} \\
\text { excess }\end{array}$ & $\begin{array}{c}1 \mathrm{wt} \% \mathrm{Pt} / \gamma-\mathrm{Al}_{2} \mathrm{O}_{3} \\
1 \mathrm{wt} \% \mathrm{Pt}-1.8 \mathrm{wt} \% \mathrm{Co} / \gamma-\mathrm{Al}_{2} \mathrm{O}_{3} \\
(\mathrm{CCP})\end{array}$ & $\mathrm{Na}$ & $\begin{array}{c}\mathrm{T}=25-300{ }^{\circ} \mathrm{C} \\
{[\mathrm{CO}]=0.1 \%,\left[\mathrm{O}_{2}\right]=0.1 \%,} \\
{\left[\mathrm{H}_{2}\right]=1 \%} \\
\text { Na loading: } 0.5-3 \mathrm{wt} \% \mathrm{Na}\end{array}$ & $\begin{array}{ll}\checkmark & \begin{array}{l}\text { Moderate promotion of } \mathrm{Na} \text { on } \\
\mathrm{Pt} / \mathrm{Al}_{2} \mathrm{O}_{3} \text { catalyst. }\end{array} \\
\checkmark & \begin{array}{l}\text { Significant volcano-type promotion } \\
\text { (maximized at } 2 \mathrm{wt} \% \mathrm{Na} \text { ) on }\end{array} \\
& \mathrm{PtCo} / \mathrm{Al}_{2} \mathrm{O}_{3} \text { catalyst. } \\
>\quad & \Delta \mathrm{X}_{\mathrm{CO}}=75 \% \text { (from } 25 \% \rightarrow 100 \% \text { ) on } 2 \mathrm{wt} \% \mathrm{Na} \\
\text { promoted } \mathrm{PtCo} / \mathrm{Al}_{2} \mathrm{O}_{3} .\end{array}$ & [38] \\
\hline
\end{tabular}


Table 1. Cont.

\begin{tabular}{|c|c|c|c|c|c|}
\hline Reactants & Catalyst, (promotion method applied) & Promoter & Reaction conditions & Promotion highlights and optimal achievements & Ref. \\
\hline $\begin{array}{l}\mathrm{CO}, \mathrm{O}_{2}, \mathrm{H}_{2} \\
\quad \text { excess }\end{array}$ & $\begin{array}{c}2 \mathrm{wt} \% \mathrm{Pt} / \gamma-\mathrm{Al}_{2} \mathrm{O}_{3} \\
(\mathrm{CCP})\end{array}$ & $\mathrm{Mg}$ & $\begin{array}{c}\mathrm{T}=100-250{ }^{\circ} \mathrm{C} \\
{[\mathrm{CO}]=1 \%,\left[\mathrm{O}_{2}\right]=0.75 \%} \\
{\left[\mathrm{H}_{2}\right]=65 \%} \\
{\left[\mathrm{CO}_{2}\right]=20 \%,\left[\mathrm{H}_{2} \mathrm{O}\right]=2 \%} \\
\mathrm{Mg} \text { loading }=3 \mathrm{wt} \% \mathrm{Mg}\end{array}$ & $\begin{array}{ll}\checkmark & \begin{array}{l}\text { Both CO oxidation and PROX reactions were } \\
\text { significantly promoted by } 3 \mathrm{wt} \% \mathrm{Mg} \text {. }\end{array} \\
\checkmark & \begin{array}{l}\text { For PROX reaction both } \mathrm{CO} \text { conversion and } \\
\text { selectivity were enhanced in } 150-230{ }^{\circ} \mathrm{C} .\end{array} \\
> & \Delta \mathrm{T}_{50}=-20{ }^{\circ} \mathrm{C} \text { for } \mathrm{CO}+\mathrm{O}_{2} \text { reaction at moist } \\
\text { conditions }\left(2 \% \mathrm{H}_{2} \mathrm{O} \text { on stream). }\right. \\
\Delta \quad \begin{array}{l}\Delta \mathrm{X}_{\mathrm{CO}}>35 \% \text { and } \Delta \mathrm{S}_{\mathrm{CO}}>15 \% \text { for } \mathrm{PROX} \\
\text { reaction }\left(\max \mathrm{X}_{\mathrm{CO}}=93 \% \text { and max } \mathrm{S}_{\mathrm{CO}}=62 \%\right. \\
\left.\text { at } 170{ }^{\circ} \mathrm{C}\right) \text { on } 3 \mathrm{wt} \% \mathrm{Mg} \text {-promoted catalyst. }\end{array}\end{array}$ & [39] \\
\hline $\begin{array}{l}\mathrm{CO}, \mathrm{O}_{2}, \mathrm{H}_{2} \\
\quad \text { excess }\end{array}$ & $\begin{array}{c}\mathrm{Pt} \text { film on }(\mathrm{K}) \mathrm{\beta Al}_{2} \mathrm{O}_{3} \text { solid electrolyte } \\
\text { (EPOC) }\end{array}$ & K & $\begin{array}{c}\mathrm{T}=195^{\circ} \mathrm{C} \\
{[\mathrm{CO}]=0.4 \%,\left[\mathrm{O}_{2}\right]=0.2 \%,} \\
{\left[\mathrm{H}_{2}\right]=16 \%} \\
\theta_{\mathrm{K}}=0-4 \%\end{array}$ & 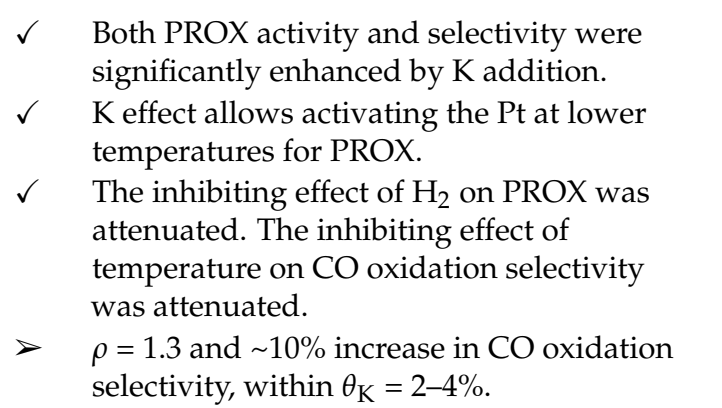 & [40] \\
\hline
\end{tabular}




\subsubsection{Light Hydrocarbons Oxidation}

(i) Alkenes oxidation

The oxidation of ethylene over polycrystalline Pt films has been extensively studied under electropositive promotion (EPOC) by Na via a $\mathrm{Na}^{+}$-conducting $\beta^{\prime \prime} \mathrm{Al}_{2} \mathrm{O}_{3}$ solid electrolyte, by Vayenas and co-workers [18,42] (Table 2). Both promoting and poisoning effects induced by alkali have been observed: low Na coverages (typically $<8 \%$ ) were found to cause increases in the reaction rate (up to $\rho=2$ ), while larger Na coverages led to a significant decrease of rate, which eventually falls well below the initial value corresponding to $\mathrm{Na}$-free Pt surface (Figure 7). The data was interpreted in terms of (i) Na-enhanced oxygen chemisorption and (ii) poisoning of the surface by accumulation of Na compounds.

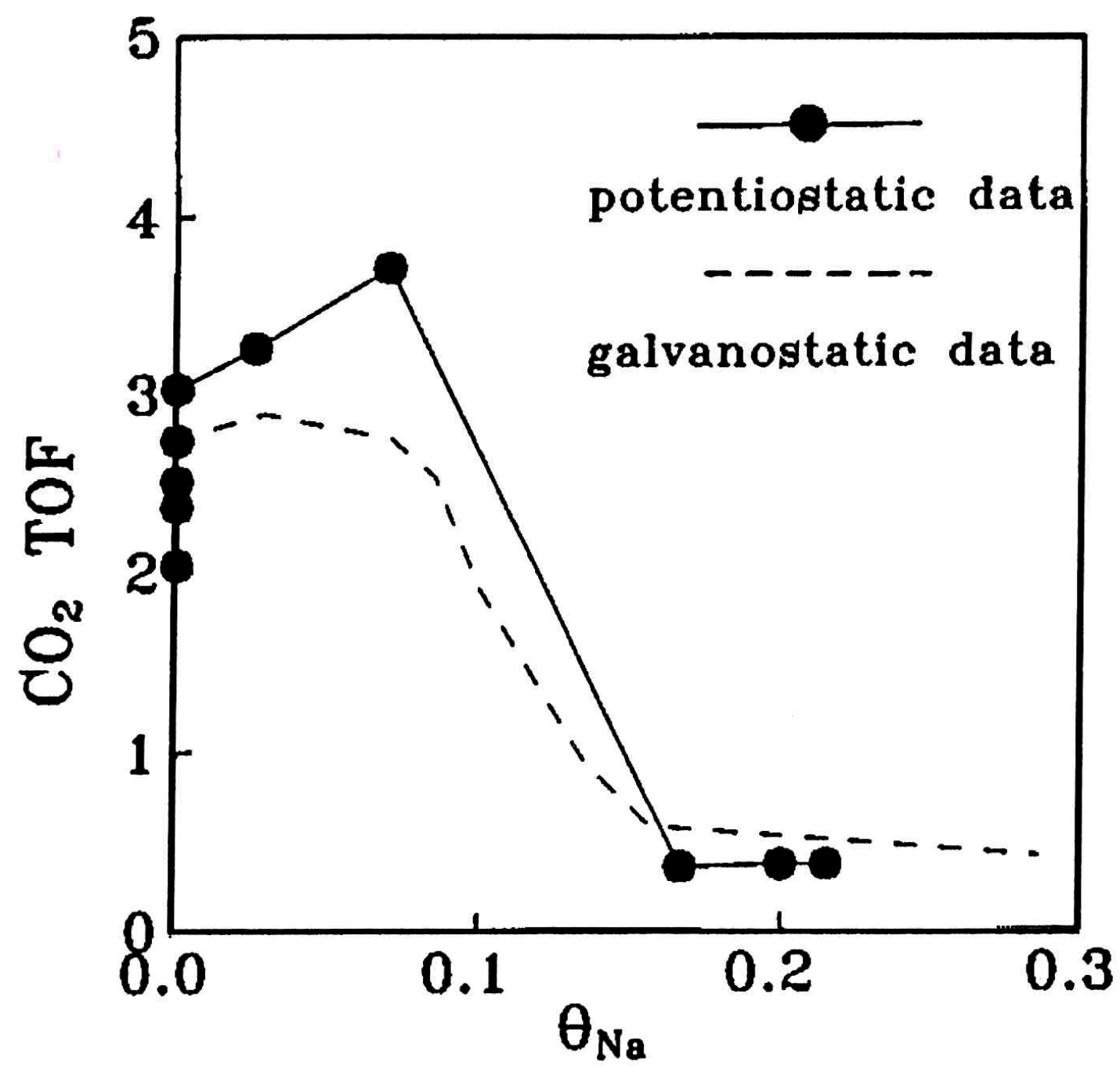

Figure 7. Rate as a function of $\mathrm{Na}$ coverage for both potentiostatic and galvanostatic experiments for $\left[\mathrm{O}_{2}\right]=8.0 \%\left[\mathrm{C}_{2} \mathrm{H}_{4}\right]=4.2 \%$ (balance $\mathrm{He}$ ) mixture at $352^{\circ} \mathrm{C}$. Data was acquired in a $\mathrm{Pt} /(\mathrm{Na}) \beta^{\prime \prime} \mathrm{Al}_{2} \mathrm{O}_{3} / \mathrm{Au}$ galvanic cell (Reprinted with permission from Ref. [18]; Copyright 1996, Elsevier).

According to the authors, low Na coverage gives rise to an enhanced chemisorption of $\mathrm{O}_{2}$ at the expense of ethylene, resulting in an increased rate. At high sodium coverages both (i) and (ii) factors operate synergistically to poison the system: the increased strength of the $\mathrm{Pt}-\mathrm{O}$ bond and the coverage of the catalytic surface by compounds of Na strongly suppress the rate. Kinetic results obtained over a $\mathrm{Pt}(111)-\mathrm{Na}$ model catalyst, dosed with several amounts of $\mathrm{Na}$ by vapour deposition (CCP), were found to mirror the behaviour of the $\mathrm{Pt} / \beta^{\prime \prime} \mathrm{Al}_{2} \mathrm{O}_{3}$ catalyst promoted by the EPOC concept [18]. This 
strongly suggested that Na pumped from the solid electrolyte via electrical polarization is indeed the key species for the promoting or poisoning phenomena. In addition, these results demonstrated that electrochemical promotion of catalysis (EPOC) and surface promotion by conventional means (CCP) obey the same physiochemical rules in the case of alkaline promoting cations. This is well documented nowadays but it was unclear at those early steps of electrochemical promotion studies.

The Pt-catalysed propene oxidation has been also extensively studied by Filkin et al. [20] under in situ electrochemical promotion (EPOC) by sodium, using polycrystalline $\mathrm{Pt}$ films deposited on $\mathrm{Na}^{+}$-conducting $\beta^{\prime \prime} \mathrm{Al}_{2} \mathrm{O}_{3}$. Depending on propene and oxygen reactants partial pressures, fully reversible promotion and poisoning effects were observed as a function of sodium coverage as follows. As $\left[\mathrm{O}_{2}\right] /\left[\mathrm{C}_{3} \mathrm{H}_{6}\right]$ decreases, the effects of Na promotion rapidly increase: for $\left[\mathrm{O}_{2}\right] /\left[\mathrm{C}_{3} \mathrm{H}_{6}\right]=5.7$, where the activity of Na-free $\mathrm{Pt}$ is highest, the maximum enhancement ratio $\rho_{\max }=\mathrm{r}_{\max }$ (on Na-promoted $\mathrm{Pt}$ ) $/ \mathrm{r}_{\mathrm{o}}$ (on Na-free Pt) is equal to 1.1 , which then increases to $\rho_{\max }=2.3$ at $\left[\mathrm{O}_{2}\right] /\left[\mathrm{C}_{3} \mathrm{H}_{6}\right]=2.0$, where $\mathrm{Na}$-free $\mathrm{Pt}$ activity is lower. These maxima enhancement ratios where obtained at moderate $\mathrm{Na}$ coverages (not specified) while higher $\mathrm{Na}$ coverages cause poisoning of the propene oxidation rate. The larger poisoning was obtained in the case of $\left[\mathrm{O}_{2}\right] /\left[\mathrm{C}_{3} \mathrm{H}_{6}\right]=5.7$ (Table 2). A Na-modified chemisorption of the reactants considered ( $\mathrm{Na}$ enhances oxygen chemisorption and inhibits propene chemisorption) on a Langmuir-Hinselwood type reaction accounted all the experimental findings. Using X-ray Photoelectron Spectroscopy (XPS), Auger Electron Spectroscopy (AES) and postreaction Na K edge XANES (X-ray Absorption Near Edge Structure) the authors have demonstrated that under reaction conditions the promoter phase consists of small amounts of 3D sodium carbonate crystallites, while thick layers of this sodium surface compound were responsible for rate inhibition in the poisoning regime. Notably, these promoter and poisoning phases, although stable at reaction temperatures investigated, were readily destroyed via electrochemical Na pumping away from the catalyst by the application of electrical polarizations of opposite sign [20].

Other studies involving the propene oxidation over Pt films using the EPOC concept as well, were reported by Vernoux and co-workers [43,44]. In these studies Pt was interfaced with NASICON $\left(\mathrm{Na}_{3} \mathrm{Zr}_{2} \mathrm{Si}_{2} \mathrm{PO}_{12}\right)$, an alternative $\mathrm{Na}^{+}$-conductor, acting therefore as a Na source for its electrochemical pumping to the $\mathrm{Pt}$ catalyst surface. The authors used two distinguished propene/oxygen gas phase compositions, near stoichiometric $\left(\mathrm{C}_{3} \mathrm{H}_{6} / \mathrm{O}_{2}=0.04 \% / 0.2 \%\right)$ and excess oxygen $\left(\mathrm{C}_{3} \mathrm{H}_{6} / \mathrm{O}_{2}=0.04 \% / 8.3 \%\right)$ conditions, to investigate the effect of $\mathrm{Na}$ on the catalytic system under consideration at $\mathrm{T} \sim 300{ }^{\circ} \mathrm{C}$ (Table 2). They found that under oxygen excess Na coverages larger than $3 \%$ cause a slight poisoning of the propene oxidation rate $(\rho \sim 0.8)$. However, under near-stoichiometric conditions, sodium had strong beneficial effect $(\rho=3.5)$ on the Pt-catalysed propene oxidation rate, which is maximized at a $\theta_{\mathrm{Na}} \sim 3.6 \%$; the rate was then slightly decreased when higher (up to $6 \%$ ) sodium coverages were supplied. Cyclic voltammetry studies indicated that sodium promoter exists in the form of $\mathrm{Na}_{2} \mathrm{CO}_{3}$ and $\mathrm{NaHCO}_{3}$ surface phases during reaction [43], in agreement with earlier studies by Filkin et al. [20].

In this line, de Lucas-Consuegra et al. $[45,46]$ have more recently studied the propene oxidation under EPOC of a Pt film interfaced with a $\mathrm{K}^{+}$-conducting $\beta \mathrm{Al}_{2} \mathrm{O}_{3}$ solid electrolyte, that is, using potassium as promoter species. They found that the reaction can be strongly promoted at the temperature interval of $\sim 200-300{ }^{\circ} \mathrm{C}$, under both near-stoichiometric and oxygen-rich conditions. Rate enhancement ratios of the order of $\rho=7$ were achieved for a catalyst polarization of about $-2 \mathrm{~V}$ (Table 2); parameters' values necessary for the estimation of the corresponding alkali coverage are not available in the paper. Cyclic voltammetry, FTIR and SEM-EDX studies enable the authors to identify the formation of stable potassium oxide and superoxide phases upon electrical polarization. These species were responsible for the promotional phenomena. In addition, due to the stability of the potassium surface compounds formed, a permanent promotional effect was observed.

The effect of electropositive modifiers on hydrocarbons oxidation over conventional highly dispersed catalysts (CCP) was also investigated by Yentekakis and co-workers [47]. In particular, they studied the propene oxidation over Na-promoted $\mathrm{Pt}(\mathrm{Na}) / \gamma-\mathrm{Al}_{2} \mathrm{O}_{3}$ catalysts under oxygen excess 
(1000 ppm propene $+5 \% \mathrm{O}_{2}$ ). Significant activity enhancements were observed for a Na-loading of $\sim 1.5-2.6 \mathrm{wt} \%$ (or $0.68-1.13 \times 10^{-3} \mathrm{mmol}$ effective $\mathrm{Na} / \mathrm{g}_{\text {cat }}$ ) [47]. Optimal promotion was achieved for $2.6 \mathrm{wt} \% \mathrm{Na}$ loading, corresponding to a nominal sodium coverage of $\theta_{\mathrm{Na}} \sim 23 \%$ (Equation (4) by using $d_{\mathrm{Na}}=3.314 \times 10^{19}$ atoms $/ \mathrm{m}^{2}$ ), causing a significant shift of the propene light-off temperature to about $60^{\circ} \mathrm{C}$ lower values (Figure 8, Table 1). Rate enhancement ratios as high as $\rho \sim 10$ can be calculated from these results. It is worth noting that the aforementioned promotional effects were recorded under oxygen excess conditions, typical of lean-burn combustion engines. The Na-induced enhancement of oxygen adsorption on the $\mathrm{Pt}$ surface, which is predominately covered by propene even at these excess oxygen gas phase conditions, was considered to be responsible for the observed promotional effect.

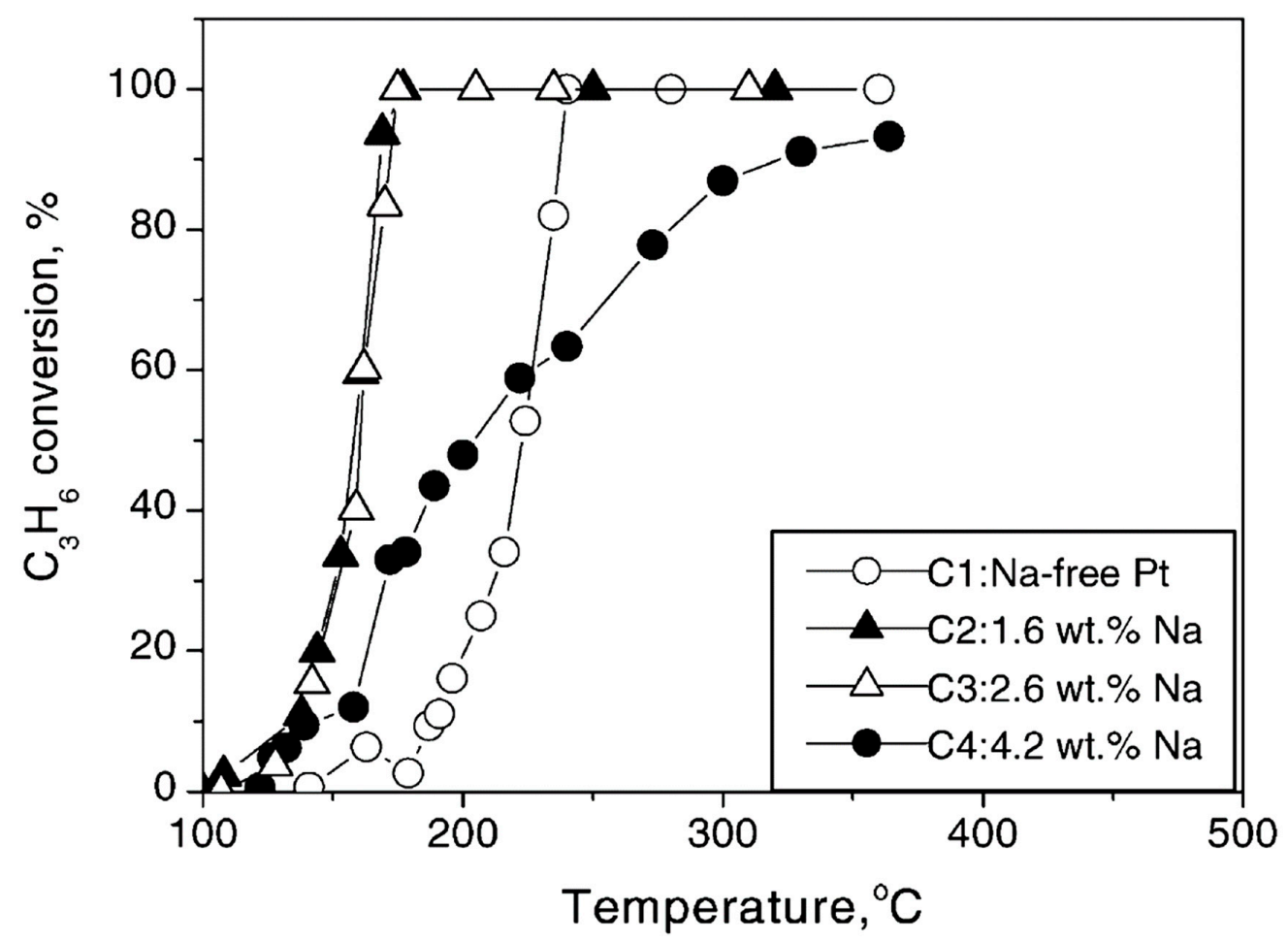

Figure 8. The effect of temperature on the conversion of $\mathrm{C}_{3} \mathrm{H}_{6} \mathrm{Na}$-dosed $\mathrm{Pt}(\mathrm{Na}) / \gamma-\mathrm{Al}_{2} \mathrm{O}_{3}$ catalysts under $\mathrm{C}_{3} \mathrm{H}_{6}+\mathrm{O}_{2}$ reaction at oxygen rich conditions: 1000 ppm $\mathrm{C}_{3} \mathrm{H}_{6}+5 \% \mathrm{O}_{2}$; catalyst weight $70 \mathrm{mg}$; total flow rate was varying as $F_{t}=210,126,62.5$ and $52 \mathrm{~cm}^{3} / \mathrm{min}$ for $\mathrm{C} 1, \mathrm{C} 2, \mathrm{C} 3$ and $\mathrm{C} 4$ catalysts, respectively, in order to keep the effective contact time of $\mathrm{C}_{3} \mathrm{H}_{6}$ constant at $4 \mathrm{~s}$. (The effective contact time is defined as: surface Pt atoms/reactant molecules/s) (Reprinted with permission from Ref. [47]; Copyright 2005, Elsevier).

(ii) Alkanes oxidation

An EPOC study regarding the propane oxidation on Pt-based catalysts under Na-promotion supplied via a (Na) $\beta^{\prime \prime} \mathrm{Al}_{2} \mathrm{O}_{3}$ solid electrolyte has been reported by Kotsionopoulos and Bebelis [48]. The activity was dramatically inhibited by $\mathrm{Na}$-addition even at low $\mathrm{Na}$ coverages, over a wide range of propane/oxygen ratios (Table 2). Under stoichiometric conditions $\left(\left[\mathrm{O}_{2}\right] /\left[\mathrm{C}_{3} \mathrm{H}_{8}\right]=1 \% / 0.2 \%\right)$ and $\mathrm{T}=320{ }^{\circ} \mathrm{C}$, a Na coverage as small as $\theta_{\mathrm{Na}} \sim 2.5 \%$ leads to a significant decrease of the reaction rate of 625 times. The poisoning effect was more pronounced at higher temperatures (e.g., 360, 400 and $440^{\circ} \mathrm{C}$ ). This poisoning effect of electropositive promoters on $\mathrm{Pt}$ for alkanes oxidation can be attributed to the weak adsorption of alkanes compared to oxygen. A latter study published by the same authors dealt with the electrochemical characterization of the aforementioned catalytic system [49]. In this work they observed, in good agreement with some of the studies mentioned above, that the sodium promoter is on the metal surface mainly forming carbonate, bicarbonate and oxide phases. 
Table 2. Electropositive promotion of PGMs-catalysed alkenes and alkanes oxidation.

\begin{tabular}{|c|c|c|c|c|c|}
\hline Reactants & Catalyst and (Promotion method applied) & Promoter & Reaction conditions & Promotion highlights and optimal achievements & Ref. \\
\hline \multicolumn{6}{|c|}{ Alkenes oxidation (Alkene $+\mathrm{O}_{2}$ ) } \\
\hline $\mathrm{C}_{2} \mathrm{H}_{4}, \mathrm{O}_{2}$ & $\begin{array}{c}\text { Pt-film over (Na) } \beta^{\prime \prime} \mathrm{Al}_{2} \mathrm{O}_{3} \\
\text { (EPOC) }\end{array}$ & $\mathrm{Na}$ & $\begin{array}{c}\mathrm{T}=291{ }^{\circ} \mathrm{C} ; \\
{\left[\mathrm{C}_{2} \mathrm{H}_{4}\right]=0.021 \%,\left[\mathrm{O}_{2}\right]=} \\
5 \% \\
\theta_{\mathrm{Na}}=0-3 \%\end{array}$ & $\begin{array}{l}\checkmark \quad \begin{array}{l}\text { Only rate inhibition was found at such } \\
\text { extreme fuel lean conditions. }\end{array} \\
>\quad \text { A Na coverage of } \theta_{\mathrm{Na}}>\sim 1.5 \% \text { suffices to } \\
\text { cause a } 70 \% \text { rate inhibition (poisoning). }\end{array}$ & [42] \\
\hline $\mathrm{C}_{2} \mathrm{H}_{4}, \mathrm{O}_{2}$ & $\begin{array}{c}\text { Pt film over }(\mathrm{Na}) \beta^{\prime \prime} \mathrm{Al}_{2} \mathrm{O}_{3} \text { solid electrolyte } \\
\text { (EPOC) }\end{array}$ & $\mathrm{Na}$ & $\begin{array}{c}\mathrm{T}=300-470{ }^{\circ} \mathrm{C} \\
{\left[\mathrm{C}_{2} \mathrm{H}_{4}\right]=4.2 \%,\left[\mathrm{O}_{2}\right]=8} \\
\text { and } 16.2 \% \\
\theta_{\mathrm{Na}}=0-35 \%\end{array}$ & $\begin{array}{l}\checkmark \quad \text { Na induces both promotion and poisoning. } \\
\text { Moderate } \theta_{\mathrm{Na}} \text {, typically }<8 \% \text {, causes } \\
\text { promotion, larger } \theta_{\mathrm{Na}} \text { causes rate inhibition. } \\
\text { Results obtained on a } \mathrm{Pt}(111) \text {-Na model } \\
\text { catalyst mirror the behaviour of the } \\
\text { EPOC system. } \\
\checkmark \quad \text { No promotional and/or poisoning effects } \\
\text { occur at high temperatures }\left(\mathrm{T}>\sim 460{ }^{\circ} \mathrm{C}\right) . \\
\rho \sim 2 \text { with } \theta_{\mathrm{Na}}=8 \% \text { at } 280{ }^{\circ} \mathrm{C} \text { and }\left[\mathrm{C}_{2} \mathrm{H} \mathrm{H}_{4}\right]= \\
4.2 \%,\left[\mathrm{O}_{2}\right]=16.9 \% ; \rho \sim 2 \text { with } \theta_{\mathrm{Na}}=8 \% \text { at } 352 \\
{ }^{\circ} \mathrm{C},\left[\mathrm{C}_{2} \mathrm{H}_{4}\right]=4.2 \%,\left[\mathrm{O}_{2}\right]=8 \%\end{array}$ & [18] \\
\hline $\mathrm{C}_{3} \mathrm{H}_{6}, \mathrm{O}_{2}$ & $\begin{array}{c}\text { Pt film over }(\mathrm{Na}) \beta^{\prime \prime} \mathrm{Al}_{2} \mathrm{O}_{3} \text { solid electrolyte } \\
\text { (EPOC) }\end{array}$ & $\mathrm{Na}$ & $\begin{array}{c}\mathrm{T}=340{ }^{\circ} \mathrm{C} \\
{\left[\mathrm{C}_{3} \mathrm{H}_{6}\right]=0.62 \%,\left[\mathrm{O}_{2}\right]=} \\
0-7 \%\end{array}$ & $\begin{array}{l}\checkmark \quad \text { Volcano type promotion optimized at } \\
\text { moderate Na coverages. Promotion effects } \\
\text { increase with decreasing }\left[\mathrm{O}_{2}\right] /\left[\mathrm{C}_{2} \mathrm{H}_{4}\right] \\
\text { (promotion is superior under fuel-rich } \\
\text { conditions). High Na coverages deactivate } \\
\text { catalyst due to excessive accumulation of } 3 \mathrm{D} \\
\mathrm{Na}_{2} \mathrm{CO}_{3} \text { species; these species can be readily } \\
\text { removed electrochemically, accomplishing } \\
\text { catalyst re-activation. } \\
P=1.1 \text { at }\left[\mathrm{O}_{2}\right] /\left[\mathrm{C}_{2} \mathrm{H}_{4}\right]=5.7, \mathrm{~T}=340{ }^{\circ} \mathrm{C} ; \rho= \\
2.2 \text { at }\left[\mathrm{O}_{2}\right] /\left[\mathrm{C}_{2} \mathrm{H}_{4}\right]=4.0, \mathrm{~T}=340{ }^{\circ} \mathrm{C} ; \rho=2.3 \text { at } \\
{\left[\mathrm{O}_{2}\right] /\left[\mathrm{C}_{2} \mathrm{H}_{4}\right]=2.0, \mathrm{~T}=340^{\circ} \mathrm{C}}\end{array}$ & [20] \\
\hline
\end{tabular}


Table 2. Cont.

\begin{tabular}{|c|c|c|c|c|c|}
\hline Reactants & Catalyst and (Promotion method applied) & Promoter & Reaction conditions & Promotion highlights and optimal achievements & Ref. \\
\hline $\mathrm{C}_{3} \mathrm{H}_{6}, \mathrm{O}_{2}$ & $\begin{array}{l}\text { Pt film over } \mathrm{NaSICon}\left(\mathrm{Na}_{3} \mathrm{Zr}_{2} \mathrm{Si}_{2} \mathrm{PO}_{12}\right) \text { solid } \\
\text { electrolyte } \\
\text { (EPOC) }\end{array}$ & $\mathrm{Na}$ & $\begin{array}{c}\mathrm{T}=300{ }^{\circ} \mathrm{C}, \theta_{\mathrm{Na}}=0-6 \% \\
-\mathrm{C}_{3} \mathrm{H}_{6} / \mathrm{O}_{2}=0.04 \% / 0.2 \% \\
\text { (stoich.) } \\
-\mathrm{C}_{3} \mathrm{H}_{6} / \mathrm{O}_{2}=0.04 \% / 8.3 \% \\
\left(\mathrm{O}_{2} \text {-rich) }\right.\end{array}$ & $\begin{array}{l}\checkmark \quad \text { Strong promotion by } \mathrm{Na} \text { under } \\
\text { near-stoichiometric } \mathrm{C}_{3} \mathrm{H}_{6} / \mathrm{O}_{2} \text { conditions; no } \\
\text { promotion or moderate poisoning under } \\
\text { oxygen excess (lean-burn) conditions. Under } \\
\text { reaction conditions promoter phase exists as } \\
\mathrm{Na}_{2} \mathrm{CO}_{3} \text { and } \mathrm{NaHCO}_{3} \text {. } \\
\rho=3.5 \text { with } \theta_{\mathrm{Na}}=3.6 \% \text { at }\left[\mathrm{C}_{3} \mathrm{H}_{6}\right] /\left[\mathrm{O}_{2}\right]= \\
0.04 / 0.2, \mathrm{~T}=300{ }^{\circ} \mathrm{C} ; \rho=0.8 \text { with } \theta_{\mathrm{Na}}>\sim 2 \% \\
\text { at }\left[\mathrm{C}_{3} \mathrm{H}_{6}\right] /\left[\mathrm{O}_{2}\right]=0.04 / 8.3, \mathrm{~T}=300^{\circ} \mathrm{C}\end{array}$ & $\begin{array}{l}{[43]} \\
{[44]}\end{array}$ \\
\hline $\mathrm{C}_{3} \mathrm{H}_{6}, \mathrm{O}_{2}$ & $\begin{array}{c}\text { Pt film over }(\mathrm{K}) \mathrm{\beta Al}_{2} \mathrm{O}_{3} \text { solid electrolyte } \\
\text { (EPOC) }\end{array}$ & K & $\begin{array}{c}\mathrm{T}=190-310{ }^{\circ} \mathrm{C} \\
{\left[\mathrm{C}_{3} \mathrm{H}_{6}\right]=2000 \mathrm{ppm},\left[\mathrm{O}_{2}\right]} \\
=1-7 \%\end{array}$ & 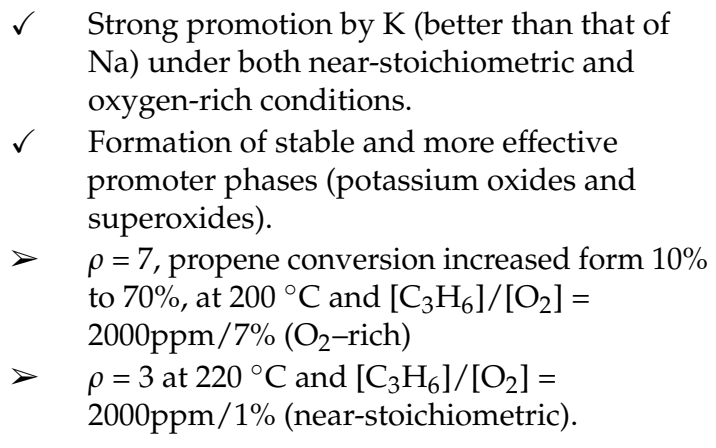 & $\begin{array}{l}{[45]} \\
{[46]}\end{array}$ \\
\hline $\mathrm{C}_{3} \mathrm{H}_{6}, \mathrm{O}_{2}$ & $\begin{array}{c}0.5 \mathrm{wt} \% \mathrm{Pt} / \gamma-\mathrm{Al}_{2} \mathrm{O}_{3} \\
(\mathrm{CCP})\end{array}$ & $\mathrm{Na}$ & $\begin{array}{c}\mathrm{T}=100-500{ }^{\circ} \mathrm{C} \\
{\left[\mathrm{C}_{3} \mathrm{H}_{6}\right]=1000 \mathrm{ppm},\left[\mathrm{O}_{2}\right]} \\
=5 \% \\
\text { Na-loadings: } 0,1.6,2.6 \\
4.2 \mathrm{wt} \%\end{array}$ & 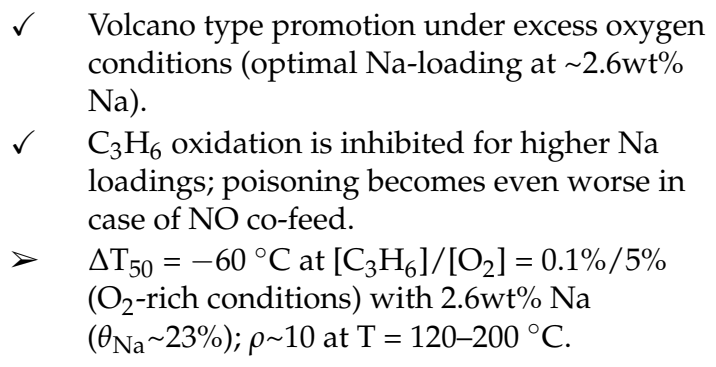 & [47] \\
\hline
\end{tabular}


Table 2. Cont

\begin{tabular}{|c|c|c|c|c|c|}
\hline Reactants & Catalyst and (Promotion method applied) & Promoter & Reaction conditions & Promotion highlights and optimal achievements & Ref. \\
\hline \multicolumn{6}{|c|}{ Alkanes oxidation (alkane $+\mathrm{O}_{2}$ ) } \\
\hline $\mathrm{C}_{3} \mathrm{H}_{8}, \mathrm{O}_{2}$ & $\begin{array}{c}\text { Pt film over }(\mathrm{Na}) \beta^{\prime \prime} \mathrm{Al}_{2} \mathrm{O}_{3} \text { solid electrolyte } \\
\text { (EPOC) }\end{array}$ & $\mathrm{Na}$ & $\begin{array}{c}\mathrm{T}=320-440{ }^{\circ} \mathrm{C} \\
{\left[\mathrm{C}_{3} \mathrm{H}_{8}\right]=0.2 \%,\left[\mathrm{O}_{2}\right]=1 \%} \\
\theta_{\mathrm{Na}}=0-3 \%\end{array}$ & $\begin{array}{l}\checkmark \quad \text { Na addition to the catalyst causes only } \\
\text { poisoning of the rate. Low } \theta_{\mathrm{Na}}=1-3 \% \text { are } \\
\text { enough to cause up to } 3 \text { orders of magnitude } \\
\text { rate poisoning }(\rho \sim 0.002) \text {. Under reaction } \\
\text { conditions Na forms carbonate, bicarbonate } \\
\text { and oxide phases. } \\
>\quad \text { Strong poisoning: } \rho \sim 0.002 \text { for } \theta_{\mathrm{Na}}>\sim 2.5 \% \text { at } \mathrm{T} \\
=440{ }^{\circ} \mathrm{C} \text {. }\end{array}$ & $\begin{array}{l}{[48]} \\
{[49]}\end{array}$ \\
\hline $\mathrm{CH}_{4}, \mathrm{O}_{2}$ & $\begin{array}{c}5(\text { or } 2.5) w \mathrm{t}^{\%} \mathrm{Pd} / \gamma-\mathrm{Al}_{2} \mathrm{O}_{3} \\
(\mathrm{CCP})\end{array}$ & $\mathrm{Na}, \mathrm{K}, \mathrm{Ba}, \mathrm{Ca}$ & $\begin{array}{r}\mathrm{T}=250-600{ }^{\circ} \mathrm{C} ; \\
{\left[\mathrm{CH}_{4}\right]=500 \mathrm{ppm},\left[\mathrm{O}_{2}\right]=} \\
8 \%,\left[\mathrm{H}_{2} \mathrm{O}\right]=5 \%,\left[\mathrm{CO}_{2}\right]= \\
5 \% \\
\text { Loadings: } \mathrm{Ca}: 0.38,0.76 \\
1.5 \mathrm{wt} \% ; \mathrm{Ba}=5 \mathrm{wt} \% ; \mathrm{K}= \\
1.48 \mathrm{wt} \% ; \mathrm{Na}=0.87 \mathrm{wt} \%\end{array}$ & $\begin{array}{l}\checkmark \quad \text { Both beneficial and detrimental effects on } \\
\mathrm{CH}_{4} \text { oxidation were found depending on the } \\
\text { promoter, catalyst composition and } \\
\text { pre-treatment. Promotion was achieved with } \\
\text { Ca-doping and after cooling in } \\
\text { inert atmosphere. } \\
\checkmark \quad \text { No promotion (even inhibition) was observed } \\
\text { by Na and } \mathrm{K} \text { addition at the specific } \\
\text { loadings used. } \\
\text { Highest activities for } 2.5 \mathrm{wt} \% \mathrm{Pd} / \gamma-\mathrm{Al}_{2} \mathrm{O}_{3} \text { and } \\
5 \mathrm{wt} \% \mathrm{Pd} / \gamma-\mathrm{Al}_{2} \mathrm{O}_{3} \text { were obtained with } 0.38 \\
\text { and } 0.76 \mathrm{wt} \% \mathrm{Ca} \text { addition, respectively, that } \\
\text { is, at a weight ratio Ca:Pd equal to } 0.15 \text { in } \\
\text { both cases. }\end{array}$ & {$[50]$} \\
\hline
\end{tabular}


Olsson and co-workers [50] studied the effect of the addition of alkalis $(\mathrm{Na}, \mathrm{K})$ and alkaline earths $\left(\mathrm{Ba}, \mathrm{Ca}\right.$ ) on $\mathrm{Pd} / \mathrm{Al}_{2} \mathrm{O}_{3}$ catalyst for methane combustion (CCP). Both beneficial and detrimental effects on methane oxidation were observed. High loadings of alkaline modifiers caused reaction inhibition. No promotion was induced by $\mathrm{Na}$ and $\mathrm{K}$ modifiers, while Ba- and Ca-doping caused reaction inhibition. However, when using a specific catalyst pre-treatment, which leads to the removal of surface hydroxyl species, promotional effects of Ca were recorded at Ca loadings where they previously observed reaction inhibition. The $\mathrm{Ca} / \mathrm{Pd}$ ratio was found to be critical for the aforementioned promotion. $\mathrm{A}$ $\mathrm{Ca} / \mathrm{Pd}$ ratio of 0.15 was favourable. The modification of the redox properties of palladium and the formation of $\mathrm{PdO}$ were considered the origin of this promotion, which overcomes the alkaline-induced inhibition of methane adsorption (activation) on increased electronic density catalyst particles surfaces which occurs in parallel.

Comparatively overviewing the literature findings of Section 3.1.2 summarized in Table 2, the following general features and conclusions can emerge.

Alkali addition on PGMs-based catalyst is detrimental for alkanes oxidation reactions that was attributed to the low adsorption propensity of alkanes on PGMs surfaces which becomes worse due to the alkali induced promotion of oxygen adsorption and the concomitant O-poisoning of the surfaces.

On the opposite, alkenes oxidation on PGMs is substantially promoted by electropositive promoters, attributed to the opposite trend of their adsorption compared to alkanes: The alkali-induced enhancement on oxygen adsorption counterbalances its coverage on a PGM surface, predominantly covered by the alkene molecules on the unpromoted surface, resulting to an enhancement on reaction probability (promotion).

The alkenes oxidation followed volcano type promotion upon increasing promoter loading, resulting from the competitive adsorption of the reactants (Langmuir-Hinshelwood type reaction) and the formation of 3D alkali carbonates and their excessive accumulation on the surface at high promoter loadings.

The main promotion characteristics were qualitatively similar between EPOC and CCP studies, although the intensity of the promotion was larger in the latter case: maximum rate enhancement ratios $(\rho)$ obtained were 3.5 and 10 by using EPOC and CCP, respectively. An ultimate contact between nanodispersed active phase particles and promoter species, which is favoured in $\mathrm{CCP}$, is most probably responsible for this superiority.

\subsubsection{NO Reduction by CO}

The first study of the effect of electropositive promoters on the Pt-catalysed NO reduction by $\mathrm{CO}$ was reported by Palermo et al. [17]. The EPOC was applied by means of a Pt/ $\mathrm{Na}^{+}$-conducting $\beta^{\prime \prime} \mathrm{Al}_{2} \mathrm{O}_{3} / \mathrm{Au}$ cell. The promotional effect of $\mathrm{Na}$ on the $\mathrm{Pt} / \mathrm{NO}+\mathrm{CO}$ system was strongly dependent on the reaction temperature, gas composition and Na coverage. For instance, at high CO/NO ratios the effect of $\mathrm{Na}$ was marginal and according to the authors this was attenuated by $\mathrm{CO}$ island formation and limited availability of chemisorbed NO. At low $\mathrm{CO} / \mathrm{NO}$ ratios the effect of $\mathrm{Na}$ was also relatively small, because, as authors conclude, the $\mathrm{CO}+\mathrm{O}$ reaction is limited by the low $\mathrm{CO}$ coverage. However, at the intermediate $\mathrm{CO} / \mathrm{NO}$ regime, where the above constrains do not apply, Na strongly accelerates the reaction: rate gains of up to $\rho=13$ for $\mathrm{N}_{2}$ production compared to the unpromoted $\mathrm{Na}$-free $\mathrm{Pt}$ rate were achieved (Table 3). Significant increases to $\mathrm{N}_{2}$ selectivity of the system (up to $30 \%$ ) were also obtained (Figure 9). Significant progressive changes in the apparent activation energy of the $\mathrm{NO}+\mathrm{CO}$ reaction upon varying the promoter coverage, similar to that obtained with the $\mathrm{Pt} / \mathrm{O}_{2}+\mathrm{CO}$ catalytic system [16], were also recorded in this study. The observed promotional phenomena, on both rate and selectivity, were attributed to the enhanced $\mathrm{NO}$ versus $\mathrm{CO}$ chemisorption and the extended dissociation of the chemisorbed NO molecules, both induced by Na-promoter. 
Table 3. Electropositive promotion of PGMs-catalysed $\mathrm{NO}$ reduction by $\mathrm{CO}(\mathrm{NO}+\mathrm{CO})$

\begin{tabular}{|c|c|c|c|c|c|}
\hline Reactants & Catalyst and (Promotion method applied) & Promoter & Reaction conditions & Promotion highlights and maximum achievements & Ref. \\
\hline $\mathrm{NO}, \mathrm{CO}$ & $\begin{array}{c}\text { Pt film over }(\mathrm{Na}) \beta^{\prime \prime} \mathrm{Al}_{2} \mathrm{O}_{3} \text { solid electrolyte } \\
(\mathrm{EPOC})\end{array}$ & $\mathrm{Na}$ & $\begin{array}{c}\mathrm{T}=300-400{ }^{\circ} \mathrm{C} \\
{[\mathrm{CO}]=0-1.5 \%,[\mathrm{NO}]=} \\
0-1.5 \% \\
{[\mathrm{NO}] /[\mathrm{CO}]=} \\
0.75 \% / 0.75 \% \\
\theta_{\mathrm{Na}}=3-20 \%\end{array}$ & 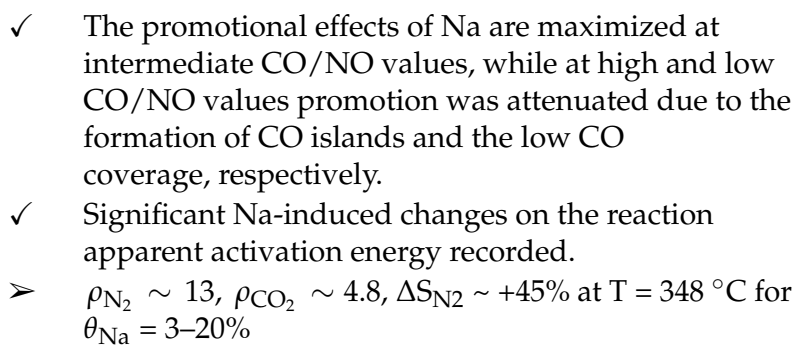 & [17] \\
\hline $\mathrm{NO}, \mathrm{CO}$ & $\begin{array}{l}\text { Rh film over }(\mathrm{Na}) \beta^{\prime \prime} \mathrm{Al}_{2} \mathrm{O}_{3} \text { solid electrolyte } \\
\text { (EPOC) }\end{array}$ & $\mathrm{Na}$ & $\begin{aligned} \mathrm{T} & =307^{\circ} \mathrm{C} \\
{[\mathrm{CO}] } & =[\mathrm{NO}]=1 \%\end{aligned}$ & $\begin{array}{l}\checkmark \quad \text { Sodium coverage }\left(\theta_{\mathrm{Na}}\right), \text { catalyst work function }(\Delta \Phi) \\
\text { and catalyst potential }\left(\mathrm{V}_{\mathrm{WR}}\right) \text { are directly correlated; } \\
\theta_{\mathrm{Na}} \text { and } \Delta \Phi \text { varying linearly with } \mathrm{V}_{\mathrm{WR}} \text {. Low sodium } \\
\text { coverages ca. } 1-2 \% \text { are able to create significant } \\
\text { promotion of the Rh-catalysed NO+CO (but less than } \\
\text { that obtained on Pt catalysts). } \\
>\quad \rho_{\mathrm{N}_{2}} \sim 3.1, \rho_{\mathrm{CO}_{2}} \sim 1.4, \rho_{\mathrm{N}_{2} \mathrm{O}}=0.3, \Delta \mathrm{S}_{\mathrm{N}_{2}} \sim+50 \% \\
(24 \% \rightarrow 80 \%) \text { at } \mathrm{T}=307^{\circ} \mathrm{C} \text {, for } \theta_{\mathrm{Na}} \sim 1-2 \%\end{array}$ & $\begin{array}{l}{[51]} \\
{[52]}\end{array}$ \\
\hline $\mathrm{NO}, \mathrm{CO}$ & $\begin{array}{c}0.5 \mathrm{wt} \% \mathrm{Pt} / \gamma-\mathrm{Al}_{2} \mathrm{O}_{3} \\
(\mathrm{CCP})\end{array}$ & $\mathrm{K}, \mathrm{Rb}, \mathrm{Cs}$ & $\begin{array}{c}\mathrm{T}=150-500{ }^{\circ} \mathrm{C} \\
{[\mathrm{CO}]=0-3 \%,[\mathrm{NO}]=0-3 \%} \\
\text { Promoter loadings used: } \\
\text { wt } \% \text { Rb: } 1.9,9.7,15.5 \\
\mathrm{wt} \% \mathrm{Cs}: 9.0,15.0,24.0 \\
\mathrm{wt} \% \mathrm{~K}: 2.7,4.4,8.8\end{array}$ & 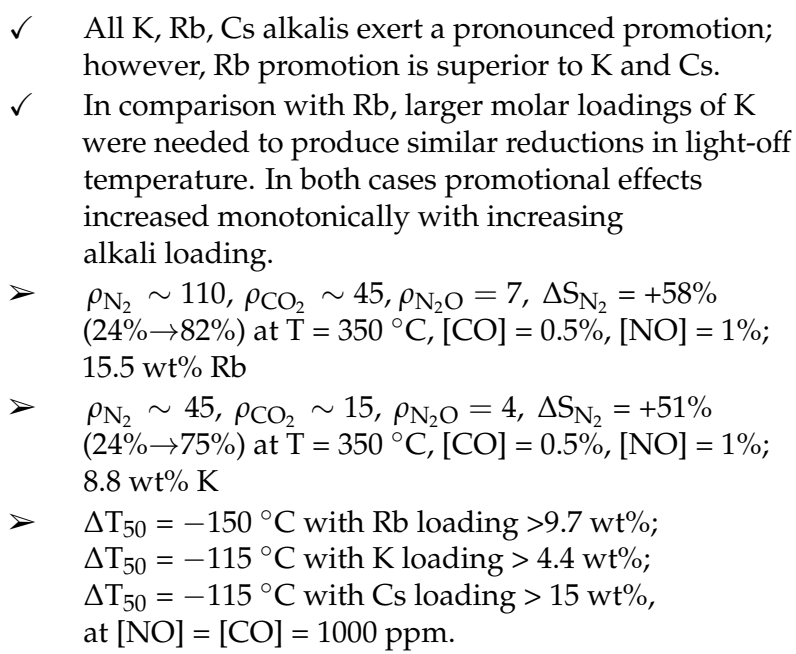 & [53] \\
\hline
\end{tabular}


Table 3. Cont

\begin{tabular}{|c|c|c|c|c|c|}
\hline Reactants & Catalyst and (Promotion method applied) & Promoter & Reaction conditions & Promotion highlights and maximum achievements & Ref. \\
\hline $\mathrm{NO}, \mathrm{CO}$ & $\begin{array}{c}0.5 \mathrm{wt} \% \mathrm{Pd} / \mathrm{YSZ} \\
(\mathrm{CCP})\end{array}$ & $\mathrm{Na}$ & $\begin{array}{c}\mathrm{T}=352^{\circ} \mathrm{C} \\
{[\mathrm{CO}]=0-4 \%,[\mathrm{NO}]=0-4 \%} \\
\text { Na loadings: } 0.017,0.034, \\
0.068 \text { and } 0.102 \mathrm{wt} \% \text { (or } \\
6 / 1,3 / 1,1.5 / 1 \text { and } 1 / 1 \\
\text { Pd / Alkali) }\end{array}$ & $\begin{array}{l}\checkmark \quad \text { Volcano type promotion was obtained with an } \\
\text { optimal Na-loading equal to } 0.034 \mathrm{wt} \% \mathrm{Na} \text { (i.e., } \\
\text { Pd/alkali molar ratio }=3 / 1 \text { ), taking into account both } \\
\text { activity and } \mathrm{N}_{2} \text { - selectivity. } \\
>\quad \rho_{\mathrm{N}_{2}} \sim 2, \rho_{\mathrm{CO}_{2}} \sim 1.5, \rho_{\mathrm{N}_{2} \mathrm{O}}=1, \Delta \mathrm{S}_{\mathrm{N}_{2}}=+20 \% \text { (from } \\
\sim 50 \% \text { to } \sim 70 \% \text { ) at } \mathrm{T}=352{ }^{\circ} \mathrm{C}, \\
{[\mathrm{CO}]=[\mathrm{NO}]=1 \% \text { for } 0.034 \mathrm{wt} \% \mathrm{Na} \text {. }}\end{array}$ & [54] \\
\hline $\mathrm{NO}, \mathrm{CO}, \mathrm{O}_{2}$ & $\begin{array}{c}1 \mathrm{wt} \% \mathrm{Pd} /\left(\gamma-\mathrm{Al}_{2} \mathrm{O}_{3} \text { or } \mathrm{CZ}\right) \\
(\mathrm{CCP})\end{array}$ & $\mathrm{Ba}$ & $\begin{array}{c}\mathrm{T}=50-300{ }^{\circ} \mathrm{C} \\
{[\mathrm{CO}]=2.2 \%,[\mathrm{NO}]=0.2 \%} \\
{\left[\mathrm{O}_{2}\right]=1 \%} \\
\text { Ba-loadings: } 0,1,5 \text { and } 15 \\
\text { wt } \% \text { Ba }\end{array}$ & 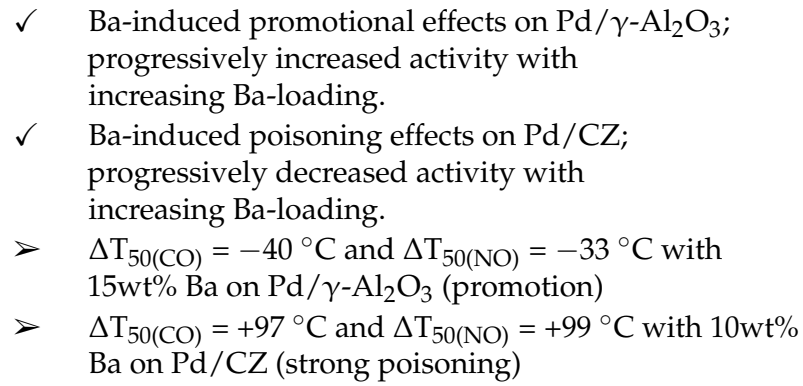 & [55] \\
\hline
\end{tabular}




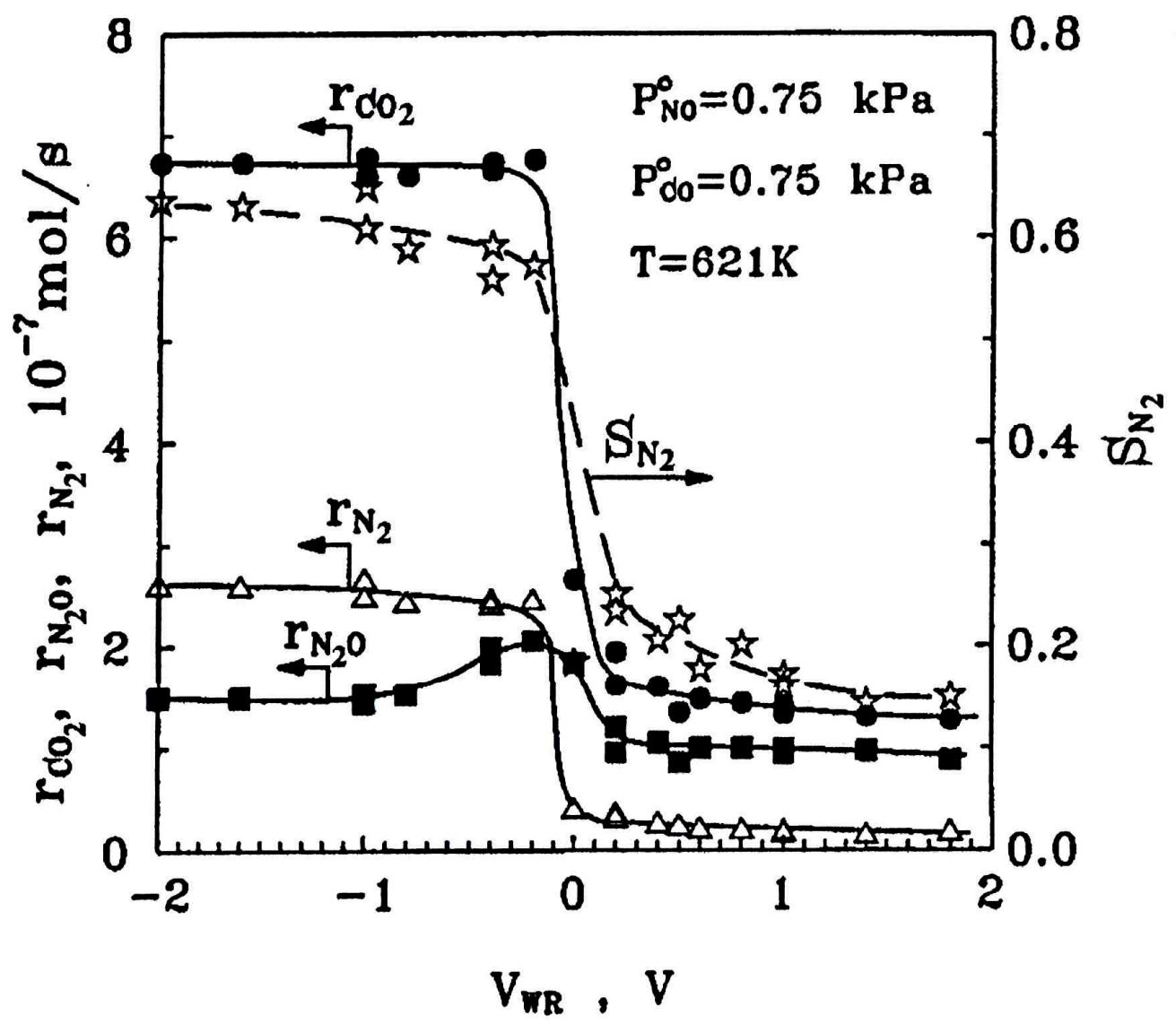

Figure 9. Effect of catalyst potential on the $\mathrm{CO}_{2}, \mathrm{~N}_{2}$ and $\mathrm{N}_{2} \mathrm{O}$ formation rates and the selectivity towards $\mathrm{N}_{2}$ during the EPOC by Na of the Pt-catalysed $\mathrm{NO}+\mathrm{CO}$ reaction. Conditions: $[\mathrm{NO}]=[\mathrm{CO}]=0.75 \%$, $\mathrm{T}=348{ }^{\circ} \mathrm{C}$. Data was acquired in a $\mathrm{Pt} /(\mathrm{Na}) \beta^{\prime \prime} \mathrm{Al}_{2} \mathrm{O}_{3} / \mathrm{Au}$ galvanic cell. (Reprinted with permission from Ref. [17]; Copyright 2005, Elsevier).

Another EPOC (by Na) study using a $\mathrm{Rh} /(\mathrm{Na}) \beta^{\prime \prime} \mathrm{Al}_{2} \mathrm{O}_{3} / \mathrm{Au}$ galvanic cell was performed by Williams et al. [51,52]. They showed that the NO reduction by $\mathrm{CO}$ can also be promoted over $\mathrm{Rh}$ catalyst. Rate enhancement ratios of $\rho_{\mathrm{N}_{2}}=3.1, \rho_{\mathrm{CO}_{2}}=1.4$ and $\rho_{\mathrm{N}_{2} \mathrm{O}}=0.3$ were observed at $\mathrm{T}=307^{\circ} \mathrm{C}$ and stoichiometric $\mathrm{CO} / \mathrm{NO}$ gas reaction conditions $([\mathrm{NO}]=[\mathrm{CO}]=1 \%$ ) for a sodium coverage as low as $2 \%$ (Table 3), together with a large increase in $\mathrm{N}_{2}$-selectivity: from $24 \%$ on the electrochemically cleaned Na-free Rh to $80 \%$ on Rh electrochemically dosed with $\theta_{\mathrm{Na}}=2 \%$. These promotional effects were attributed to the Na-induced NO dissociation, which was considered as the rate limiting step for the NO reduction by CO process. Using XPS and work function $(\Delta \Phi)$ measurements the authors also demonstrated that the Na coverage on the catalyst surface can be controlled through the externally imposed catalyst potential; a linear relationship of catalyst work function and $\theta_{\mathrm{Na}}$ with catalyst potential was experimentally demonstrated in this study [51,52].

Konsolakis et al. [53] studied the $\mathrm{NO}+\mathrm{CO}$ reaction on ( $\mathrm{K}, \mathrm{Rb}$ and $\mathrm{Cs})$-promoted, conventional $(\mathrm{CCP})$, highly dispersed $\mathrm{Pt} / \gamma-\mathrm{Al}_{2} \mathrm{O}_{3}$ catalysts, over a wide range of temperature (ca. $150-500{ }^{\circ} \mathrm{C}$ ), partial pressures of reactants and promoter loadings (Table 3). All these alkalis were found to be very active promoters for the reaction, however, optimal promotion was achieved by rubidium: rate increases by factors as high as $\rho_{\mathrm{N}_{2}}=110$ and $\rho_{\mathrm{CO}_{2}}=45$ for the production of $\mathrm{N}_{2}$ and $\mathrm{CO}_{2}$, respectively, relative to alkali-free $\mathrm{Pt}$ were obtained, accompanied by substantial increases in $\mathrm{N}_{2}$-selectivity by up to $\sim 60 \%$ (Figure 10) [53]. The effects of $\mathrm{K}$ and Cs-promotion mirror those of Rb-promotion but they were less pronounced. Light-off measurements in the temperature range of $150-500{ }^{\circ} \mathrm{C}$ and under stoichiometric conditions (1000 ppm NO $1000 \mathrm{ppm} \mathrm{CO}$ ) showed that the NO conversion performance of alkali-free $\mathrm{Pt}$ is very poor (never exceeding $60 \%$ ), whereas the $0.5 \mathrm{wt} \% \mathrm{Pt}(\mathrm{Rb}) / \gamma-\mathrm{Al}_{2} \mathrm{O}_{3}$ catalyst 
promoted with $9.7 \mathrm{wt} \% \mathrm{Rb}$ (optimally promoted catalyst), exhibited $100 \% \mathrm{NO}$ and CO conversions with $100 \% \mathrm{~N}_{2}$-selectivity at $\sim 350{ }^{\circ} \mathrm{C}$. In addition, $115^{\circ} \mathrm{C}$ decrease on the NO light-off temperature $\left(\mathrm{T}_{50}\right)$ was obtained for $\mathrm{K}$ and $\mathrm{Cs}$, while a larger decrease in $\mathrm{T}_{50}$ by $\sim 150{ }^{\circ} \mathrm{C}$ was obtained by $\mathrm{Rb}$-promotion (Figure 11).
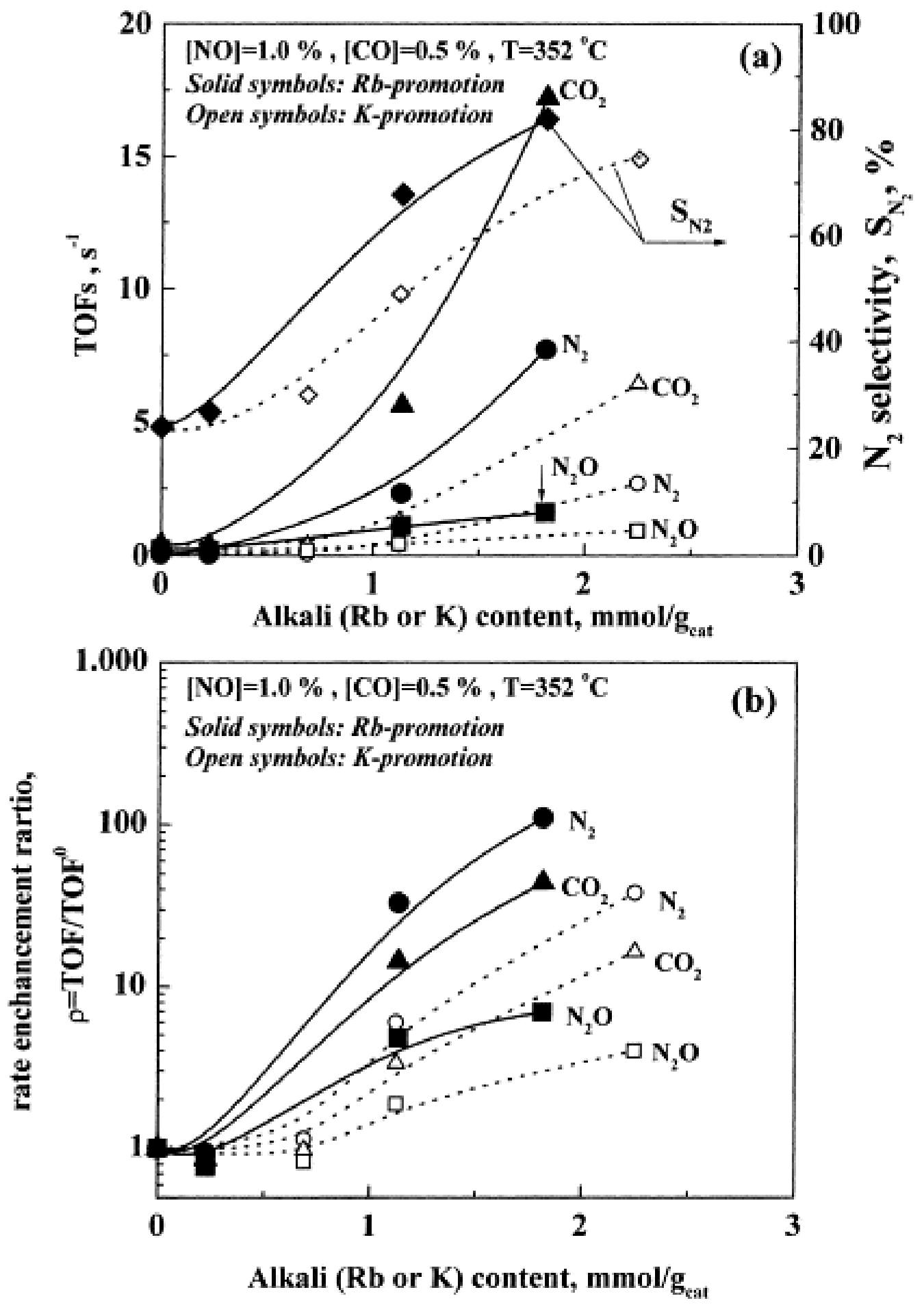

Figure 10. (a) Effect of $\mathrm{Rb}$ or $\mathrm{K}$ content of $\mathrm{Pt} / \gamma-\mathrm{Al}_{2} \mathrm{O}_{3}$ catalyst on the turnover (TOF) formation rates of $\mathrm{N}_{2}, \mathrm{CO}_{2}$ and $\mathrm{N}_{2} \mathrm{O}$ and on $\mathrm{N}_{2}$-selectivity at $\mathrm{T}=352{ }^{\circ} \mathrm{C}$, [NO] $=1 \%,[\mathrm{CO}]=0.5 \%$. (b) Corresponding enhancement ratio $\rho=\mathrm{TOF} / \mathrm{TOF}^{0}$ values. Solid lines and symbols refer to Rb-promotion, dashed lines and open symbols refer to K-promotion. (Reprinted with permission from Ref. [53]; Copyright 2001, Elsevier). 


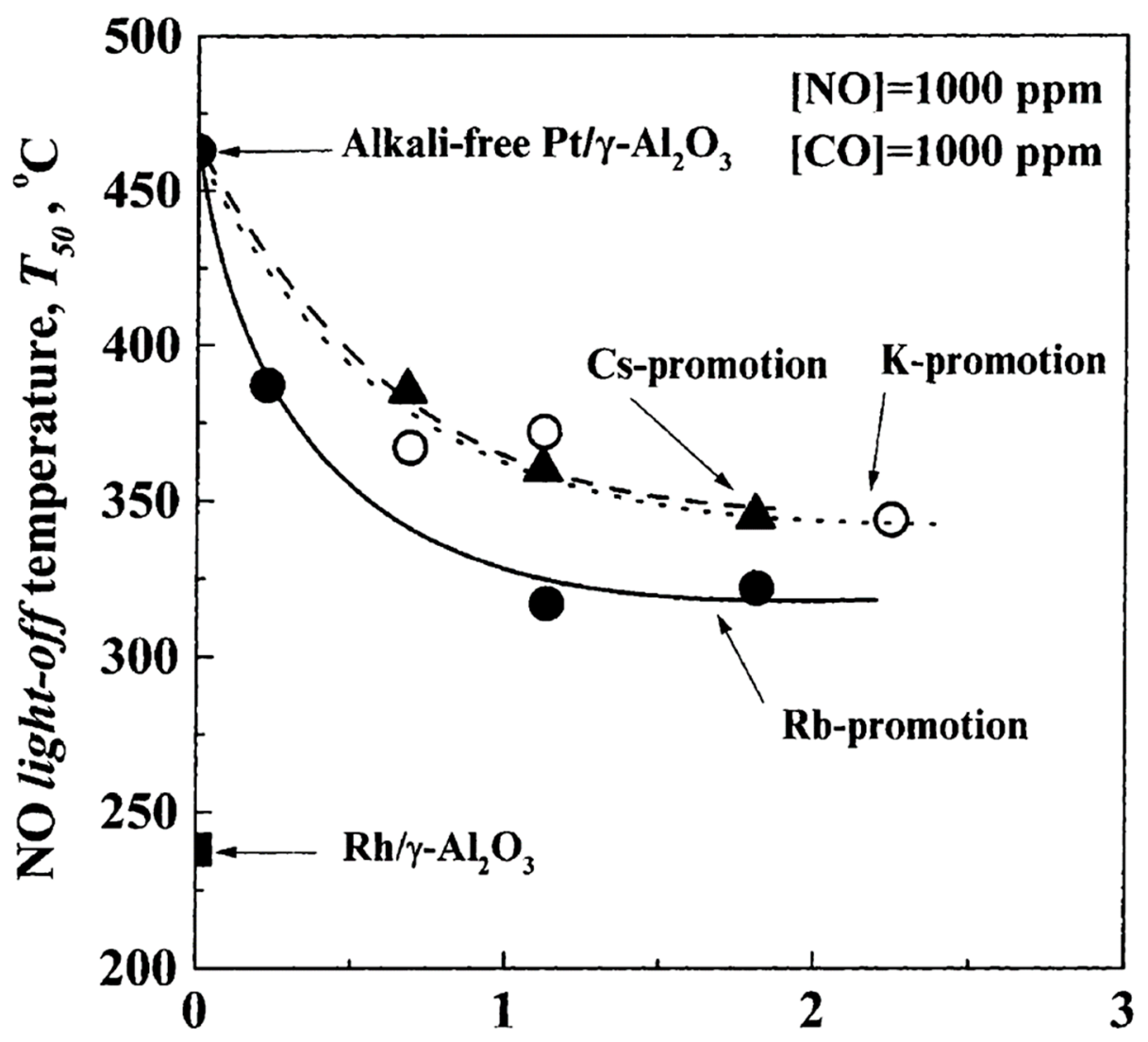

Alkali (K, Rb or Cs) content, $\mathrm{mmol} / \mathrm{g}_{\text {cat }}$

Figure 11. Effect of $\mathrm{K}-$, $\mathrm{Rb}$ - or Cs-promotion on the $\mathrm{NO}$ light-off temperature $\left(\mathrm{T}_{50}\right)$ for $\mathrm{Pt} / \mathrm{NO}+\mathrm{CO}$ system. Conditions: $[\mathrm{NO}]=1000 \mathrm{ppm},[\mathrm{CO}]=1000 \mathrm{ppm}$, total gas flow rate $\mathrm{F}_{\mathrm{t}}=80 \mathrm{~cm}^{3} \mathrm{STP} / \mathrm{min}$; catalyst weight $8( \pm 0.2) \mathrm{mg}$. ( $\left.\mathrm{w} / \mathrm{F}_{\mathrm{t}}=6 \times 10^{-3} \mathrm{~g} \mathrm{~s} / \mathrm{cm}^{3}\right)$. (Reprinted with permission from Ref. [53]; Copyright 2001, Elsevier).

The observed promotional effects were ascribed to alkali-induced changes in the chemisorption bond strengths of $\mathrm{CO}, \mathrm{NO}$ and $\mathrm{NO}$ dissociation products. The superior promotion of $\mathrm{Rb}$ compared to that of $\mathrm{K}$ was attributed to its larger size and thus to the greater electric field experienced by co-adsorbed species located at an adjacent site. On the other hand, the unexpected lower efficiency of Cs promotion compared to that of $\mathrm{Rb}$ was attributed to a change in the adsorption site of NO due to the very large Cs ion [53].

More recently Konsolakis and Yentekakis [54] reported on the promotional effect of $\mathrm{Na}$ on the Pd-catalysed $\mathrm{NO}+\mathrm{CO}$ reaction (CCP). A series of Na-promoted Pd catalysts were prepared on yttria-stabilized zirconia (YSZ; $10 \mathrm{~mol}_{\%} \mathrm{Y}_{2} \mathrm{O}_{3} / \mathrm{ZrO}_{2}$ ) carrier (i.e., $\mathrm{Pd}(\mathrm{Na}) / \mathrm{YSZ}$ ), with different loadings of alkali-promoter. Both promoting and poisoning effects, regarding the Na-loading, were found in a wide range of $\mathrm{CO} / \mathrm{NO}$ ratios. For example at equimolar $\mathrm{CO} / \mathrm{NO}$ composition $([\mathrm{CO}]=[\mathrm{NO}]=1 \%)$ and $\mathrm{T}=352{ }^{\circ} \mathrm{C}$, the optimal promoter loading was found to be between $0.02-0.03 \mathrm{wt} \%$ of $\mathrm{Na}$ (corresponding to a nominal sodium coverage of $\theta_{\mathrm{Na}} \sim 3 \%$; Equation (4) with $d_{\mathrm{Na}}=3.314 \times 10^{19}$ atoms $/ \mathrm{m}^{2}$ ) which leads to $\mathrm{N}_{2}$ and $\mathrm{CO}_{2}$ formation rate enhancements by up to $\sim 200 \%$, accompanied by a significant improvement in $\mathrm{N}_{2}$-selectivity of about $20 \%$ in comparison to the un-promoted Pd/YSZ catalyst (Table 3). The promotional effects were interpreted in a similar manner to the aforementioned studies [17,51-53].

Tanikawa and Egawa [55] studied the effect of Ba-promoter on $\mathrm{NO}+\mathrm{CO}$ reaction in the presence of $\mathrm{O}_{2}$ over Pd dispersed on $\gamma-\mathrm{Al}_{2} \mathrm{O}_{3}$ and ceria-zirconia supports (CCP). They found that the activity of $\mathrm{Pd} / \gamma-\mathrm{Al}_{2} \mathrm{O}_{3}$ was gradually enhanced by increasing the Ba loading up to $15 \mathrm{wt} \%$; the light-off 
temperatures $\left(\mathrm{T}_{50}\right)$ for $\mathrm{CO}$ oxidation and $\mathrm{NO}$ reduction were decreased by 40 and $33^{\circ} \mathrm{C}$, respectively, over the optimally modified $\mathrm{Pd}(15 \% \mathrm{Ba}) / \gamma-\mathrm{Al}_{2} \mathrm{O}_{3}$. However, $\mathrm{Ba}$ addition on $\mathrm{Pd} / \mathrm{CZ}$ catalyst decreased its activity for both $\mathrm{NO}$ reduction and $\mathrm{CO}$ oxidation reactions (Table 3 ).

Finally, Lepage et al. [56] studied the effect of electropositive promoters (monovalent $\mathrm{H}^{+}, \mathrm{Na}^{+}$, $\mathrm{Rb}^{+}$and $\mathrm{Cs}^{+}$or divalent $\mathrm{Mg}^{2+}, \mathrm{Ca}^{2+}, \mathrm{Sr}^{2+}$ and $\mathrm{Ba}^{2+}$ cations) over $\mathrm{Rh}$ nanoparticles supported on a series of $\mathrm{Y}$ zeolites for the $\mathrm{NO}$ reduction by $\mathrm{CO}$ by means of infrared spectroscopy of NO adsorption to monitor the electronic modifications of Rh nanoparticles. The observed decrease in NO reduction ignition temperature $\left(\mathrm{T}_{10}\right)$ with increasing ionic radius-to-charge ratio was related to the degree of electron transfer from Rh particles to the adsorbed NO molecules. The shift of the IR band of linearly adsorbed NO to lower wavenumbers with increasing the radius/charge ratio of promoter elements substantiated this argument.

A comparative overview of the literature involved in this section and in Table 3 gives prominence to the following general features: (i) Promotion either induced by EPOC or by CCP is substantial and has qualitatively similar characteristics, although CCP leads to much larger rate enhancements; $\rho$ values in the region of 45-110 and around 13 were obtained by using CCP and EPOC, respectively. The ultimate contact and thus the higher interaction of the well dispersed active phase particles with the promoter species may be the cause of the mentioned differences on promotion intensity. (ii) Heavier alkalis were typically more effective than lighter alkalis, with $\mathrm{Rb}$ being the best. (iii) Among Pt, Pd and $\mathrm{Rh}$ precious metals, alkali promotion was significantly more effective on $\mathrm{Pt}$ than on $\mathrm{Rh}$ and $\mathrm{Pd}$. (iv) Alkali-induced enhancement of the dissociative chemisorption of $\mathrm{NO}$ was considered as a key factor for the interpretation of the aforementioned pronounced promotion.

\subsubsection{NO Reduction by Hydrocarbons or $\mathrm{H}_{2}$}

\section{(i) NO reduction by alkenes}

NO reduction by hydrocarbons under in situ electrochemical promotion (EPOC) by alkalis was firstly demonstrated by Harkness and Lambert [57] and Yentekakis et al. [58]. Using ethylene as reductant, Harkness and Lambert [57] showed that the rate of the $\mathrm{NO}+$ ethylene reaction over a Pt film interfaced with $\mathrm{Na}^{+}$-conducting $\beta^{\prime \prime} \mathrm{Al}_{2} \mathrm{O}_{3}$, linearly increased with $\theta_{\mathrm{Na}}$ al low and intermediate sodium coverages (typically $\theta_{\mathrm{Na}}<0.3$ ), achieving a plateau for higher values. Rate enhancement values $\rho$ up to 15 were obtained (Table 4 ).

On the other hand Yentekakis et al. [58] showed very pronounced NO reduction rate enhancements (using propene as the reductant) for the Pt-catalysed $\mathrm{NO}+$ propene reaction upon Na promotion over similar $\mathrm{Pt} /(\mathrm{Na}) \beta^{\prime \prime} \mathrm{Al}_{2} \mathrm{O}_{3}$ electrocatalyst. This effect was studied at $375^{\circ} \mathrm{C}$ in a wide range of $\mathrm{P}_{\mathrm{NO}}(0-7 \mathrm{kPa})$ and $\mathrm{P}_{\mathrm{C}_{3} \mathrm{H}_{6}}(0-0.4 \mathrm{kPa})$ partial pressures. The promotional effect of $\mathrm{Na}$ was found to be significant in the whole range of conditions studied. The coverage of the promoting species was determined via galvanostatic transients. These transients showed that the promotional effects maximized at a Na coverage of $\theta_{\mathrm{Na}} \sim 0.4$, for which value the maximum enhancements in $\mathrm{CO}_{2}$ and $\mathrm{N}_{2}$ rates were $\sim 7$ times larger than the rate of the unpromoted $\mathrm{Pt}$, while the $\mathrm{N}_{2}$-selectivity increased from $60 \%$ on the clean Pt surface to $80 \%$ on the optimal Na-promoted Pt surface (Table 4 ). Higher sodium coverages $\left(\theta_{\mathrm{Na}}>1\right)$ caused a gradual decrease of the promoting phenomena. This suggests that nominal sodium coverages greater than one exhibit activity much higher than clean Pt because a substantial amount of $\mathrm{Na}$ is present as 3D crystallites, as demonstrated by XPS. A Na-induced strengthening of the NO chemisorpting bond relative to propene was indicated by the kinetic data. The accompanied weakening of the $\mathrm{N}-\mathrm{O}$ bond and the concomitant extended $\mathrm{NO}$ dissociation were considered for the interpretation of the observed promotional effects. XPS data confirmed that under reaction conditions the promoter phase consists of a mixture of $\mathrm{NaNO}_{2}$ and $\mathrm{NaNO}_{3} 3 \mathrm{D}$ crystallites. At high $\mathrm{Na}$ loadings these surface promoter compounds inhibit reaction due to active sites blocking phenomena.

EPOC was also used by Williams et al. [59] for the study of NO reduction by propene over Rh film catalyst interfaced with (Na) $\beta^{\prime \prime} \mathrm{Al}_{2} \mathrm{O}_{3}$. They found that Na pumping onto Rh surface at a coverage 
as low as $\sim 2 \%$ causes a very large increase in the $\mathrm{N}_{2}$-selectivity from $45 \%$ on the $\mathrm{Na}$-free $\mathrm{Rh}$ surface to $82 \%$ on the Na-promoted surface together with beneficial effects on the reaction rate: rate enhancement ratio values of $\rho=2.4,1.7$ and 0.4 were recorded for the $\mathrm{N}_{2}, \mathrm{CO}_{2}$ and $\mathrm{N}_{2} \mathrm{O}$ productions, respectively (Table 4). In a subsequent publication [60] the authors examined the impact of $\mathrm{O}_{2}$ co-feed. It was found that upon increasing $\left[\mathrm{O}_{2}\right]$, the promotional effects of $\mathrm{Na}$ were progressively attenuated and finally reversed to poisoning for $\left[\mathrm{O}_{2}\right]=2 \%$. Similar considerations as in Reference [57] and [58] were used for the interpretation of the promotional effects, as well.

Using CCP, the group of Yentekakis [14,54] showed that the $\mathrm{NO}+$ propene reaction over $\mathrm{Pd}$ dispersed on $8 \mathrm{~mol} \% \mathrm{Y}_{2} \mathrm{O}_{3}$ stabilized $\mathrm{ZrO}_{2}$ support (YSZ) can be substantially promoted by dosing the catalyst with alkalis. In Reference [14], the rate increased by an order of magnitude accompanied by selectivity increases from $\sim 75 \%$ over the Na-free Pd/YSZ catalyst to $>95 \%$ over the optimally Na-promoted Pd/YSZ catalyst in the temperature interval of $250-450{ }^{\circ} \mathrm{C}$. The promotional effects were found to be optimized at a sodium content of $0.06 \mathrm{wt} \%$ (corresponding to nominal sodium coverage of $\sim 7 \%$; Equation (4)), while over-promotion attenuated the rate (volcano type behaviour). These promotional effects caused a decrease in the NO light-off temperature $\left(\mathrm{T}_{50}\right)$ of about $110^{\circ} \mathrm{C}$ between the optimally promoted and unpromoted Pd catalyst (Table 4). A strengthening of the chemisorption bond of $\mathrm{NO}$ relative to propene that facilitates weakening of the $\mathrm{N}-\mathrm{O}$ bond of the adsorbed $\mathrm{NO}$ molecules and thus their dissociative chemisorption was considered as the origin of the promotional effects. In ref. [54] the effects of $\mathrm{Li}, \mathrm{Na}, \mathrm{K}$ and $\mathrm{Cs}$ alkalis on Pd-catalysed $\mathrm{NO}+\mathrm{C}_{3} \mathrm{H}_{6}$ reaction were comparatively studied: Four catalysts dosed with the same alkali/ $\mathrm{Pd}=1 / 1.5$ atom/atom loading were prepared and their behaviour was compared in a wide range of $[\mathrm{NO}]$ at constant $\left[\mathrm{C}_{3} \mathrm{H}_{6}\right]=0.8 \%$ and $\mathrm{T}=380{ }^{\circ} \mathrm{C}$. All these catalyst were found significantly better in terms of activity and selectivity in comparison to the unpromoted $\mathrm{Pd} / \mathrm{YSZ}$, in the whole range of conditions investigated; Na provided the most significant promotional effects (Table 4).

Systematically expanding their studies on conventional promoted catalysts (CCP), Yentekakis and co-workers showed that $\mathrm{Pt}$ nanoparticles dispersed on $\gamma-\mathrm{Al}_{2} \mathrm{O}_{3}$ are subjected to extraordinarily effective promotion by alkalis ( $\mathrm{Li}, \mathrm{Na}, \mathrm{K}, \mathrm{Rb}$ and $\mathrm{Cs})[15,61]$ and alkaline earths $(\mathrm{Ba})[62,63]$ in both activity and $\mathrm{N}_{2}$-selectivity during the $\mathrm{NO}+$ propene reaction in the temperature interval of TWCs interest (ca. $\left.200-550{ }^{\circ} \mathrm{C}\right)$. In References $[15,61]$ rate increases by two orders of magnitude were achieved, while the selectivity towards $\mathrm{N}_{2}$ was improved from 20\% over the alkali-free unpromoted Pt catalyst, to $>95 \%$ over the optimally alkali-promoted catalysts. Best promotional effects were achieved by Rb-promotion, for which rate increases as high as 420-, 280- and 25-fold were obtained for the formation rates of $\mathrm{N}_{2}$, $\mathrm{CO}_{2}$ and $\mathrm{N}_{2} \mathrm{O}$, respectively, in comparison to the performance of the unpromoted $\mathrm{Pt} / \gamma-\mathrm{Al}_{2} \mathrm{O}_{3}$ catalyst (Table 4). Volcano type behaviour was found to be followed upon increases of promoter loadings for all cases. Thus, promotion was found to be maximized for a Li content of $1.25 \mathrm{wt} \%$, a K content of $7.1 \mathrm{wt} \%$, a Rb content of $9.7 \mathrm{wt} \%$ a Cs content of $15 \mathrm{wt} \%$ (Figure 12) [61] and a Na content of $4.18 \mathrm{wt} \%$ [15].

This very spectacular promotion in light-off diagrams (see for example Figure 13) showed that the marginal $(\sim 10 \%) \mathrm{NO}$ conversion efficiency of un-promoted $\mathrm{Pt} / \gamma-\mathrm{Al}_{2} \mathrm{O}_{3}$ can be readily proved by alkalis to values up to $100 \%$ in the temperature window of TWCs interest, offering at the same time selectivities towards $\mathrm{N}_{2}>95 \%[15,61]$. However, besides temperature, $\mathrm{NO}_{x}$ removal efficiency of automotive catalytic converters is greatly affected by the presence of oxygen in the exhausts gases, in particular under excess $\mathrm{O}_{2}$ conditions. Therefore, the $\mathrm{NO}+\mathrm{C}_{3} \mathrm{H}_{6}+$ excess $\mathrm{O}_{2}$ reaction is of higher practical significance than the $\mathrm{NO}+\mathrm{C}_{3} \mathrm{H}_{6}$ one. Hence, it was decided to analyse this reaction and the effect of $\mathrm{O}_{2}$ in a distinguishable section of the article (Section 3.2). 

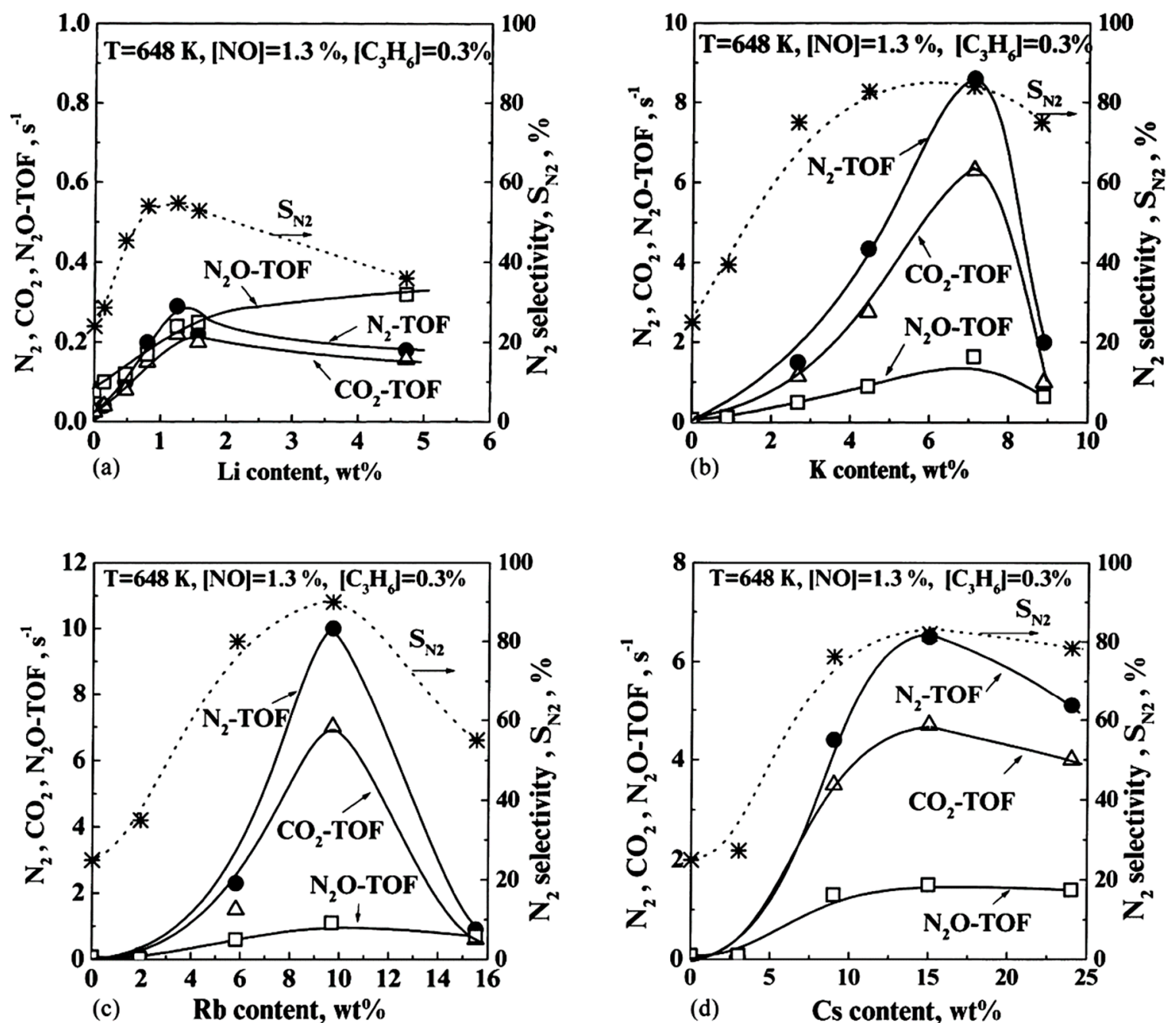

Figure 12. The effect of $\mathrm{Li}(\mathbf{a}), \mathrm{K}(\mathbf{b}), \mathrm{Rb}(\mathbf{c})$ and $\mathrm{Cs}(\mathrm{d})$ content of $0.5 \mathrm{wt} \% \mathrm{Pt} / \gamma-\mathrm{Al}_{2} \mathrm{O}_{3}$ catalyst on the turnover (TOF) formation rates of $\mathrm{N}_{2}, \mathrm{CO}_{2}$ and $\mathrm{N}_{2} \mathrm{O}$ and on $\mathrm{N}_{2}$-selectivity. Conditions: $\mathrm{T}=375{ }^{\circ} \mathrm{C}$, $[\mathrm{NO}]=1.3 \%,\left[\mathrm{C}_{3} \mathrm{H}_{6}\right]=0.3 \%$ (Reprinted with permission from Ref. [61]; Copyright 2001, Elsevier).

In the case of Ba-promotion the optimal Ba-loading was found to be $15.2 \mathrm{wt} \%$ Ba (Table 4) [62]. Using a $1000 \mathrm{ppm} \mathrm{NO}+1000 \mathrm{ppm}_{3} \mathrm{H}_{6}$ feed composition (these concentrations are close to those encountered in practical applications and commonly used in the literature as referred conditions) the authors showed that the very poor NO light-off behaviour of Ba-free $\mathrm{Pt} / \gamma-\mathrm{Al}_{2} \mathrm{O}_{3}$ catalysts, which gave a lower than $10 \% \mathrm{NO}$ conversion in the whole $200-550{ }^{\circ} \mathrm{C}$ temperature interval, can be dramatically improved (in a similar manner to alkali-promotion [15,61]), achieving $100 \%$ NO conversion at relatively low temperatures accompanied by $\mathrm{N}_{2}$-selectivities near to $100 \%$. Further studying the Ba-promoted $\mathrm{Pt} / \gamma-\mathrm{Al}_{2} \mathrm{O}_{3}$ system, the authors focussed on the effect of residual chloride, which concerns catalysts prepared from chlorine-containing precursors [63]; the detrimental effect of residual chloride on deNOx catalysis is well known. Very strikingly, it was found that when Ba is used to promote catalysts prepared from chloride-containing precursors, all the original chloride is retained, yet the catalysts exhibit very strong promotion and in every aspect their behaviours are identical to that of the chloride-free Ba-promoted catalyst [63]. This significant from the practical point of view attenuation of the inhibiting effect of chloride was rationalized in terms of formation of a stable $2 \mathrm{D} \mathrm{BaCl} \mathrm{Ba}_{2}$ phase on the catalysts surface, where the promoting effect of Ba overwhelms the poisoning effect of $\mathrm{Cl}$ and a large net promotion is resulted. 

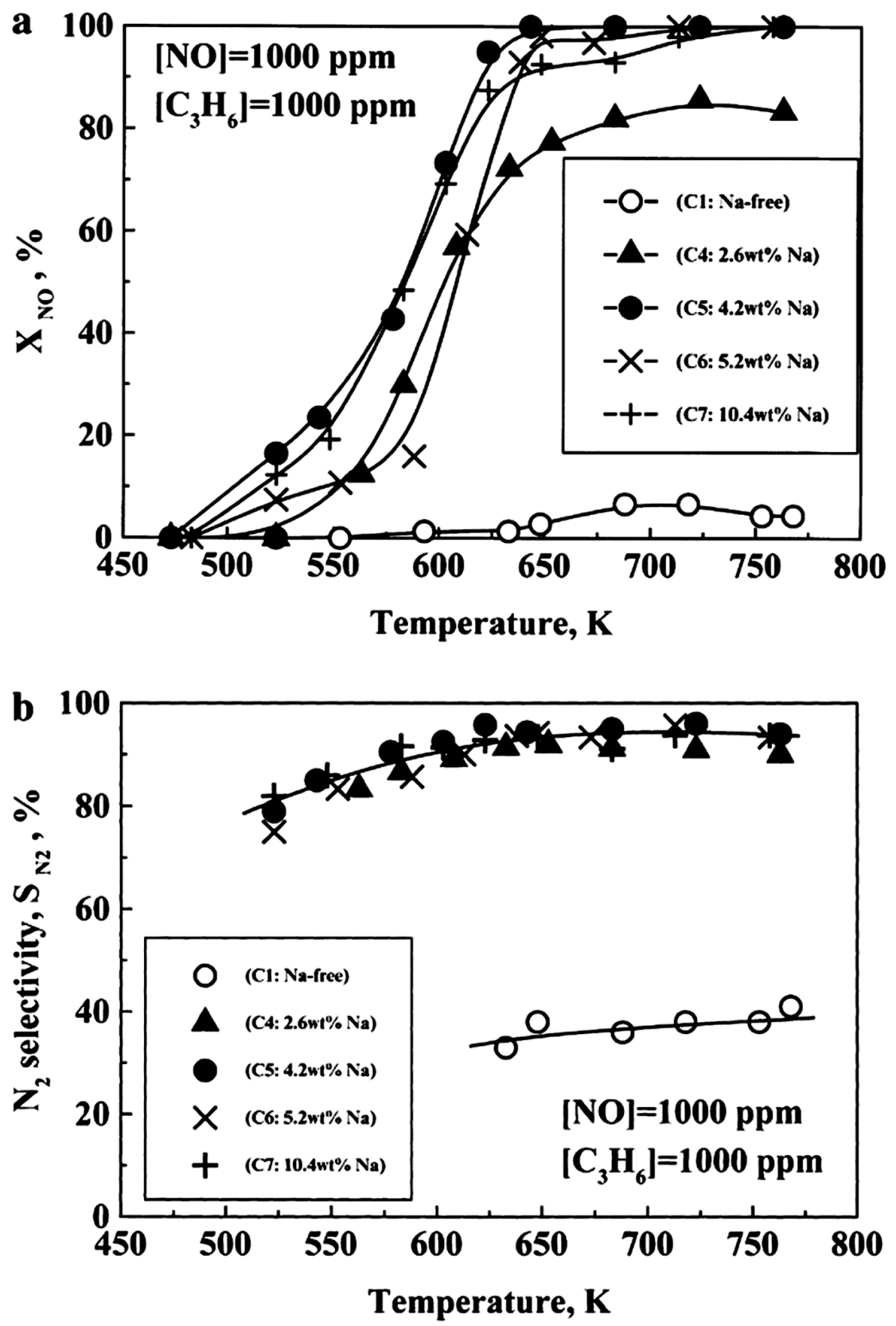

Figure 13. The conversion of $\mathrm{NO}(\mathbf{a})$ and the corresponding selectivity towards $\mathrm{N}_{2}$ (b) for Na-promoted $0.5 \mathrm{wt} \% \mathrm{Pt} / \gamma-\mathrm{Al}_{2} \mathrm{O}_{3}$ catalysts, as a function of temperature at constant reactor inlet conditions: $[\mathrm{NO}]=1000 \mathrm{ppm},\left[\mathrm{C}_{3} \mathrm{H}_{6}\right]=1000 \mathrm{ppm}$; total flow rate $\mathrm{F}_{\mathrm{t}}=80 \mathrm{~cm}^{3} \mathrm{STP} / \mathrm{min}$; catalyst weight $8( \pm 0.2) \mathrm{mg}$. (Reprinted with permission from Ref. [15]; Copyright 1999, Elsevier).

Macleod et al. [64] studied the $\mathrm{NO}+\mathrm{C}_{3} \mathrm{H}_{6}$ reaction over dispersed $\mathrm{Rh} / \gamma-\mathrm{Al}_{2} \mathrm{O}_{3}$ catalysts (CCP). $\mathrm{Rh}$ is one of the noble metals used in TWCs and its use is related to the effective NO reduction in the three-way catalytic chemistry. They found that NO reduction chemistry on Rh can also be improved by alkalis. For instance, at $375^{\circ} \mathrm{C}$, a $7.3 \mathrm{wt} \% \mathrm{Na}$ content in the catalyst was found to be optimal promoter loading, leading to a $\sim 3$-fold increase in Rh activity (Table 4). Significant increases in $\mathrm{N}_{2}$-selectivity, up to $90 \%$ were also obtained, when the unpromoted $\mathrm{Rh} / \gamma-\mathrm{Al}_{2} \mathrm{O}_{3}$ appeared to have only $53 \%$. In addition, $\mathrm{Na}$ was found to suppress de formation of $\mathrm{CO}$ and $\mathrm{HCN}$. Higher Na loadings were poisoning the catalyst bellow to its initial Na-free performance. However, it is worth noticing the substantially lower degree of promotional effect of alkalis on the NO reduction chemistry of Rh compared to that observed for Pt and Pd. 
(ii) NO reduction by alkanes

Yentekakis and co-workers $[65,66]$ studied the reduction of NO by methane over Na-dosed Pd catalyst (CCP) dispersed on yttria stabilized zirconia (YSZ) at temperatures between $350-500{ }^{\circ} \mathrm{C}$ and a wide range of reactants concentrations ( $\left.[\mathrm{NO}]=0-1.5 \%,\left[\mathrm{CH}_{4}\right]=0-25 \%\right)$. It was observed that the reaction clearly exhibits Langmuir-Hinshelwood type kinetics over Pd with characteristic rate maxima reflecting competitive adsorption of $\mathrm{NO}$ and methane; $\mathrm{NO}$ adsorption however was found to be much more pronounced than that of $\mathrm{CH}_{4}$ within the temperature range investigated. Sodium was found to cause strong poisoning of the reaction at any loading due to a Na-induced oxygen poisoning of the catalyst (derived by NO decomposition) (Table 4). The very different response of alkali promotion for the NO reduction by alkanes (strong poisoning effects) and by alkenes (strong promotional effects) is attributed to the different trends of the adsorption of the two kinds of hydrocarbons (alkanes and alkenes) on the Pt-group metal surfaces [67,68].

It is worth noting the similarities on the effect of electropositive promotion of Pt-group metals (PGM) between the alkanes or alkenes oxidation by dioxygen (Section 3.1.2) and by NO (Section 3.1.4): In both cases when the oxidation process involves alkenes, electropositive promoters induce strong promotion, whilst when the reductant agent is an alkane, electropositive promoters lead to poisoning. This is understandable in view of the different trend of alkenes and alkanes adsorption on the PGM surfaces (strong and weak, respectively $[67,68]$ ) and the influence of the promotion on it $[15,20,47,61,65,66]$ and the fact that in both cases the oxidant species are mainly based on adsorbed atomic oxygen derived by the dissociative chemisorption of molecular oxygen or NO [47].

(iii) $\mathrm{NO}$ reduction by $\mathrm{H}_{2}$ or $\mathrm{CO}+\mathrm{H}_{2}$

Besides hydrocarbons, hydrogen is also one of the gases present in automotive exhaust stream. It could also be externally supplied, by the use of a hydrocarbon reformer or another source of safe in situ hydrogen generator, for the reduction of $\mathrm{NO}_{\mathrm{x}}$ from stationary power sources and chemical plants. Notably, the $\mathrm{NH}_{3}$-Selective Catalytic Reduction process $\left(\mathrm{NH}_{3}\right.$-SCR) which is currently on of the most performing technologies for $\mathrm{deNO}_{x}$ processes in stationary power applications and chemical plants, experiences drawbacks related to the storage and slip of ammonia, although it may be pointed out that urea (as an $\mathrm{NH}_{3}$ carrier) is now commercially available for use on diesel truck and some lighter vehicles. These issues can explain the growing interest and efforts for the use of $\mathrm{H}_{2}$ as a reducing agent of $\mathrm{NO}_{\mathrm{x}}$ in the last years (e.g., [69-72]). Most of these studies have used Pt-group metals as catalysts.

The first EPOC work in this field was performed by Marina et al. [19], who studied the effect of $\mathrm{Na}$ on the Pt-catalysed $\mathrm{NO}$ reduction by $\mathrm{H}_{2}$ with $(\mathrm{Na}) \beta^{\prime \prime} \mathrm{Al}_{2} \mathrm{O}_{3}$ as a source of $\mathrm{Na}$ promoter species. Rate enhancement ratio values up to $\rho_{\mathrm{N}_{2}}=30$ were achieved for the formation of $\mathrm{N}_{2}$, accompanied by significant increases in $\mathrm{N}_{2}$-selectivity. At $375{ }^{\circ} \mathrm{C}$, Na coverage of only $6 \%$ increased the $\mathrm{N}_{2}$-selectivity from $\sim 36 \%$ on the clean Na-free Pt surface to $\sim 75 \%$ on the Na-promoted Pt surface (Table 4). The promotional effects of Na were applicable in a wide range of $\mathrm{H}_{2} / \mathrm{NO}$ gas phase compositions (ca. 0.1-3.0) and temperature (ca. $300-450{ }^{\circ} \mathrm{C}$ ).

Burch and Coleman [73] studied the effect of sodium for the selective catalytic reduction of NO by hydrogen in the presence of excess oxygen (lean-burn conditions) over $\mathrm{Na}_{2} \mathrm{O}$-modified conventional, highly dispersed $\mathrm{Pt} / \mathrm{Al}_{2} \mathrm{O}_{3}$ and $\mathrm{Pt} / \mathrm{SiO}_{2}$ catalysts $(\mathrm{CCP})$, at temperatures representative of automotive "cold-start" conditions $\left(<200^{\circ} \mathrm{C}\right)$. They found that small sodium loadings significantly increased the $\mathrm{NO}$ conversion rate while larger sodium loadings led to severe poisoning. Under oxygen excess and low temperatures $\left(<\sim 140^{\circ} \mathrm{C}\right)$ the selectivity to $\mathrm{N}_{2}$ was practically unaffected by the addition of sodium, while an adverse effect was found at higher temperatures (Table 4).

Machida et al. [74] investigated the effect of alkalis ( $\mathrm{Na}, \mathrm{K}, \mathrm{Cs})$ and alkaline earths $(\mathrm{Mg}, \mathrm{Ca}$, Ba) on Pt/ZSM5 catalysts (CCP) for the selective reduction of $\mathrm{NO}$ by $\mathrm{H}_{2}$ under $\mathrm{O}_{2}$ excess $(0.08 \%$ $\mathrm{NO}, 0.08-0.56 \% \mathrm{H}_{2}, 10 \% \mathrm{O}_{2}$ ). The optimum promotional effects were obtained with Na promoter at loadings of $10-15 \mathrm{wt} \%$, which exhibited $\mathrm{NO}_{\mathrm{x}}$ conversion higher than $90 \%$ and $\mathrm{N}_{2}$ selectivity of $\sim 50 \%$. Based on in situ Diffuse Reflectance Infrared Fourier Transform Spectroscopy (DRIFTS) studies, 
it was suggested that $\mathrm{Na}$ promotes the adsorption of $\mathrm{NO}$ as $\mathrm{NO}_{2}$-type species, which would be an intermediate towards $\mathrm{N}_{2}$ formation.

The $\mathrm{H}_{2}$-SCR process over $\mathrm{Pt}$ for automotive emissions control, however, exhibits an important disadvantage: $\mathrm{CO}$, which also coexists in exhaust stream, is strongly adsorbed on Pt surface causing inhibition of $\mathrm{NO}_{x}$ reduction. Pioneer CCP work by Lambert and co-workers [75-78] showed that Pd overcomes this poisoning effect of $\mathrm{CO}$ leading to good $\mathrm{NO}_{\mathrm{x}}$ conversions at mixed $\mathrm{H}_{2}+\mathrm{CO}$ feeds. In addition, they found that $\mathrm{Pd}$ dispersed on $10 \mathrm{wt} \% \mathrm{TiO}_{2}$-modified $\mathrm{Al}_{2} \mathrm{O}_{3}$ offers even more improved deNO ${ }_{x}$ efficiency in comparison to the $\mathrm{Pd} / \mathrm{Al}_{2} \mathrm{O}_{3}$ catalyst. The effective temperature window of these new catalyst formulations was however relatively narrow (ca. $150-200^{\circ} \mathrm{C}$ ). In a similar manner, Yentekakis and co-workers [79] studied the lean $\mathrm{NO}_{\mathrm{x}}$ reduction by $\mathrm{H}_{2}+\mathrm{CO}$ over potassium-modified $\mathrm{Pd} / \mathrm{Al}_{2} \mathrm{O}_{3}$ and $\mathrm{Pd} / \mathrm{Al}_{2} \mathrm{O}_{3}-\mathrm{TiO}_{2}$ catalysts. They found that potassium is a very active promoter of the $\mathrm{Pd} / \mathrm{Al}_{2} \mathrm{O}_{3}$ catalyst for $\mathrm{H}_{2}-\mathrm{SCR}$ process leading to significant enhancements of both $\mathrm{NO}_{\mathrm{x}}$ conversion activity and $\mathrm{N}_{2}$-selectivity of $\mathrm{Pd}$. A potassium loading of $\sim 0.25 \mathrm{wt} \%$ was found to optimize the catalyst performance in both activity and selectivity, leading to a catalyst formulation that offered up to $\sim 90 \% \mathrm{NO}_{\mathrm{x}}$ conversion with a $\mathrm{N}_{2}$-selectivity of the order of $>85 \%$ for the temperature range of $180-300{ }^{\circ} \mathrm{C}$ (Table 4 ).

\section{(iv) Direct NO decomposition}

Limited studies can be found on this topic, probably due to the necessity of high temperatures for the direct $\mathrm{NO}$ decomposition. Wang et al. [80] studied the direct decomposition of NO into nitrogen and oxygen over Na-modified $\mathrm{Pd} / \mathrm{Al}_{2} \mathrm{O}_{3}$ catalysts $(\mathrm{CCP})$ in a flow reactor. They found that the $\mathrm{NO}$ reduction activity of $\mathrm{Pd}$ was significantly promoted by pre-coating the $\mathrm{Al}_{2} \mathrm{O}_{3}$ support with $\mathrm{NaOH}$ before the impregnation with $\mathrm{Pd}$. A loading of $13 \mathrm{wt} \% \mathrm{NaOH}$ on a $4.8 \mathrm{wt} \% \mathrm{Pd} / \mathrm{Al}_{2} \mathrm{O}_{3}$ catalyst enhanced the nitrogen yield from $15 \%$ up to $60 \%$ at $\mathrm{T}=627^{\circ} \mathrm{C}$ (Table 4). The observed NO decomposition rate enhancement was attributed to the strengthening of the $\mathrm{NO}$ adsorption bond on Pd sites.

Overviewing the literature included in Section 3.1.4 and Table 4 the following general remarks can emerge:

- Alkanes oxidation, either using dioxygen (Section 3.1.2) or NO (this section) behaves similarly under electropositive promotion by alkalis: addition of alkali on PGM surfaces causes only poisoning. Interpretations given are similar in both cases, based on the low adsorption propensity of alkanes on PGM surfaces and on the O-poisoning of the surfaces resulted by the alkali-induced enhancement of NO dissociative chemisorption.

- On the opposite, electropositive promotion of the $\mathrm{NO}+$ alkenes reactions is very pronounced; apparently it is the greater observed, for emissions control catalysis model reactions reviewed in the present work, offering $\rho$ values as high as $\rho_{\mathrm{N}_{2}}=420$ and $\rho_{\mathrm{CO}_{2}}=280$.

- Some studies performing one-by-one comparison of EPOC and CCP by means of Na promoted $\mathrm{Pt} / \mathrm{NO}+\mathrm{C}_{3} \mathrm{H}_{6}$ system have demonstrated the very close similarities on the promotion output characteristics of the two methods and have convincingly argued for the similar origin of promotion in both cases.

- Once again (see Section 3.1.3) the intensity of CCP was superior to that of EPOC, indicating that an intimate contact between active phase and promoter particles succeeded by nanostructured catalysts seems to play a significant role on the promotion intensity.

- Heavier alkalis were again (see Section 3.1.3) more effective than the lighter ones; $\mathrm{Rb}$ was the best promoter.

- Among Pt, Pd and $\mathrm{Rh}$, alkali promotion was more effective on Pt, lower on Pd and even lower on Rh. As we shall see (Section 3.3) this is related to the initial, unpromoted propensity of each metal on the dissociative adsorption of NO.

- Promotion by alkalis was also found to be substantial on the $\mathrm{NO}$ reduction by $\mathrm{H}_{2}$ as well as on the direct NO decomposition reaction, although only few studies appeared in the open literature so far.

- Catalytic activity promotion was always accompanied by substantial increases on the system selectivity towards $\mathrm{N}_{2}$. 
Table 4. Electropositive promotion of PGMs-catalysed NO reduction by hydrocarbons (alkenes or alkanes), $\mathrm{H}_{2}$ or $\mathrm{H}_{2}+\mathrm{CO}$.

\begin{tabular}{|c|c|c|c|c|c|}
\hline Reactants & Catalyst and (Promotion method applied) & Promoter & Reaction conditions & Promotion highlights and maximum achievements & Ref. \\
\hline \multicolumn{6}{|c|}{ NO reduction by alkenes $(\mathrm{NO}+$ Alkene) } \\
\hline $\mathrm{NO}, \mathrm{C}_{2} \mathrm{H}_{4}$ & $\begin{array}{c}\text { Pt film over }(\mathrm{Na}) \beta^{\prime \prime} \mathrm{Al}_{2} \mathrm{O}_{3} \text { solid electrolyte } \\
\text { (EPOC) }\end{array}$ & $\mathrm{Na}$ & $\begin{array}{c}\mathrm{T}=275-450{ }^{\circ} \mathrm{C} \\
{[\mathrm{NO}]=0.5-1 \%,\left[\mathrm{C}_{2} \mathrm{H}_{4}\right]=} \\
1-3 \% \\
\theta_{\mathrm{Na}}=0-40 \%\end{array}$ & $\begin{array}{l}\checkmark \quad \text { Significant promotion in a wide range of gas } \\
\text { compositions }\left(\mathrm{C}_{2} \mathrm{H}_{4} / \mathrm{NO}=1-6\right) \text {; in all compositions } \\
\text { promotion was monotonically increased by increasing } \\
\theta_{\mathrm{Na}} \text { up to } 40 \% \text {. Significant changes in apparent } \\
\text { activation energy by varying } \theta_{\mathrm{Na}} \cdot \\
>\quad \rho_{\mathrm{CO}_{2}}=15 \text { for } \theta_{\mathrm{Na}}=\sim 30 \% \text { and }\left[\mathrm{C}_{2} \mathrm{H}_{4}\right]=1.5 \%, \\
{[\mathrm{NO}]=0.65 \% \text { at } \mathrm{T}=402{ }^{\circ} \mathrm{C}}\end{array}$ & [57] \\
\hline $\mathrm{NO}, \mathrm{C}_{3} \mathrm{H}_{6}$ & $\begin{array}{c}\text { Pt film over }(\mathrm{Na}) \beta^{\prime \prime} \mathrm{Al}_{2} \mathrm{O}_{3} \text { solid electrolyte } \\
(\mathrm{EPOC})\end{array}$ & $\mathrm{Na}$ & $\begin{array}{c}\mathrm{T}=330-400{ }^{\circ} \mathrm{C} \\
{[\mathrm{NO}]=0-6 \%,\left[\mathrm{C}_{3} \mathrm{H}_{6}\right]=} \\
0-0.4 \% \\
\theta_{\mathrm{Na}}=0-100 \%\end{array}$ & $\begin{array}{l}\checkmark \quad \text { Significant volcano type promotion observed with } \\
\text { rate increases by an order of magnitude; optimal } \\
\text { promotion achieved at } \theta_{\mathrm{Na}} \sim 30 \% \text {. Significant changes } \\
\text { in apparent activation energy upon varying } \theta_{\mathrm{Na}} \text { were } \\
\text { found. Under reaction conditions, the promoter phase } \\
\text { consists of a mixture of } \mathrm{NaNO}_{2} / \mathrm{NaNO}_{3}, \text { which at } \\
\text { high Na- loadings cause poisoning. } \\
>\quad \rho_{\mathrm{N}_{2}} \sim \rho_{\mathrm{CO}_{2}}=7, \rho_{\mathrm{N}_{2} \mathrm{O}}=3, \Delta \mathrm{S}_{\mathrm{N}_{2}}=+20 \%(60 \% \rightarrow 80 \%), \\
\text { for } \theta_{\mathrm{Na}}=\sim 30 \%,\left[\mathrm{C}_{3} \mathrm{H}_{6}\right]=0.6 \% \text {, [NO]=1.3\%, } \mathrm{T}=375{ }^{\circ} \mathrm{C}\end{array}$ & [58] \\
\hline $\mathrm{NO}, \mathrm{C}_{3} \mathrm{H}_{6}$ & $\begin{array}{c}\text { Rh film over (Na) } \beta^{\prime \prime} \mathrm{Al}_{2} \mathrm{O}_{3} \text { solid electrolyte } \\
(\mathrm{EPOC})\end{array}$ & $\mathrm{Na}$ & $\begin{array}{c}\mathrm{T}=350{ }^{\circ} \mathrm{C} \\
{[\mathrm{NO}]=1-9 \%,\left[\mathrm{C}_{3} \mathrm{H}_{6}\right]=} \\
1 \%, \\
{\left[\mathrm{O}_{2}\right]=0-2 \%}\end{array}$ & $\begin{array}{l}\checkmark \quad \text { Na promotes the Rh-catalysed NO+propene reaction, } \\
\text { especially its selectivity towards } \mathrm{N}_{2} \text {. The impact of } \\
{[\mathrm{NO}] /\left[\mathrm{C}_{3} \mathrm{H}_{6}\right] \text { ratio was studied: promotion was }} \\
\text { superior for }[\mathrm{NO}] /\left[\mathrm{C}_{3} \mathrm{H}_{6}\right]=1 \% / 1 \% \text {. The impact of } \\
\mathrm{O}_{2} \text { co-feed was also tested: upon increasing }\left[\mathrm{O}_{2}\right] \text { the } \\
\text { promotional effects of Na were progressively } \\
\text { decreased, reversing to poisoning at }\left[\mathrm{O}_{2}\right]=2 \% \text {. Under } \\
\text { promoted conditions the promoter phase consists of } \\
\text { carbonate, nitrate or both. } \\
>\quad \rho_{\mathrm{N}_{2}}=2.4, \rho_{\mathrm{CO}_{2}}=1.7, \rho_{\mathrm{N}_{2} \mathrm{O}}=0.4, \Delta \mathrm{S}_{\mathrm{N}_{2}}=+37 \% \\
(45 \% \rightarrow 82 \%), \text { for } \theta_{\mathrm{Na}}=20 \%,\left[\mathrm{C}_{3} \mathrm{H}_{6}\right]=[\mathrm{NO}]=1 \%, \\
\mathrm{~T}=350{ }^{\circ} \mathrm{C} \text {. }\end{array}$ & $\begin{array}{l}{[59]} \\
{[60]}\end{array}$ \\
\hline
\end{tabular}


Table 4. Cont

\begin{tabular}{|c|c|c|c|c|c|}
\hline Reactants & Catalyst and (Promotion method applied) & Promoter & Reaction conditions & Promotion highlights and maximum achievements & Ref. \\
\hline $\mathrm{NO}, \mathrm{C}_{3} \mathrm{H}_{6}$ & $\begin{array}{c}0.5 \mathrm{wt} \% \mathrm{Pd} / \mathrm{YSZ} \\
(\mathrm{CCP})\end{array}$ & $\begin{array}{l}\mathrm{Na}, \mathrm{Li}, \mathrm{K}, \\
\mathrm{Cs}\end{array}$ & $\begin{array}{c}\mathrm{T}=250-450{ }^{\circ} \mathrm{C} \\
{[\mathrm{NO}]=0-8 \%,\left[\mathrm{C}_{3} \mathrm{H}_{6}\right]=} \\
0-8 \% \\
\text { Na loadings: } 0-0.102 \mathrm{wt} \% \\
\text { (nominal } \theta_{\mathrm{Na}}=0-30 \% \text { ) }\end{array}$ & $\begin{array}{l}\checkmark \quad \text { Rate increases by an order of magnitude were } \\
\text { achieved. Promotion followed volcano type } \\
\text { behaviour (optimal promotion at } \sim 20 \% \theta_{\mathrm{Na}} \text { ). In } \\
\text { respect to } \mathrm{Li}, \mathrm{Na}, \mathrm{K}, \mathrm{Cs} \text { alkalis studied Na was } \\
\text { superior promoter. Significant variation of the } \\
\text { apparent activation energy with Na loading; the } \\
\text { promoted induced isokinetic effect was demonstrated. } \\
>\quad \rho_{\mathrm{N}_{2}} \sim \rho_{\mathrm{CO}_{2}} \sim 7, \rho_{\mathrm{N}_{2} \mathrm{O}} \sim 1.5, \Delta \mathrm{S}_{\mathrm{N}_{2}}=+20 \% \\
(75 \% \rightarrow 95 \%), \text { for } \theta_{\mathrm{Na}}=\sim 20 \%,[\mathrm{NO}]=1 \%, \\
{\left[\mathrm{C}_{3} \mathrm{H}_{6}\right]=0.8 \%, \mathrm{~T}=380^{\circ} \mathrm{C}} \\
\Delta \mathrm{T}_{50}=-110^{\circ} \mathrm{C} \text { at }\left[\mathrm{C}_{3} \mathrm{H}_{6}\right]=[\mathrm{NO}]=0.8 \% \text { with the } \\
\text { optimally promoted catalyst, } \theta_{\mathrm{Na}}=20 \%(0.068 \mathrm{wt} \% \\
\mathrm{Na}) .\end{array}$ & $\begin{array}{l}{[14]} \\
{[54]}\end{array}$ \\
\hline $\mathrm{NO}, \mathrm{C}_{3} \mathrm{H}_{6}$ & $\begin{array}{c}0.5 \mathrm{wt} \% \mathrm{Pt} / \gamma-\mathrm{Al}_{2} \mathrm{O}_{3} \\
(\mathrm{CCP})\end{array}$ & $\begin{array}{c}\mathrm{Na}, \mathrm{Li}, \mathrm{K}, \\
\mathrm{Rb}, \mathrm{Cs}\end{array}$ & $\begin{array}{c}\mathrm{T}=200-500{ }^{\circ} \mathrm{C} \\
{[\mathrm{NO}]=0-7 \%,\left[\mathrm{C}_{3} \mathrm{H}_{6}\right]=} \\
0.3,0.6 \% \\
\text { Alkali loadings: Li: } 0-4.7 \\
\text { wt } \% \text {; } \\
\text { Na: } 0-10.4 \mathrm{wt} \% ; \mathrm{K}: 0-8.8 \\
\mathrm{wt} \% \text {; } \\
\text { Rb: } 0-15.5 \mathrm{wt} \% \text {; Cs: } 0-24 \\
\text { wt } \% .\end{array}$ & 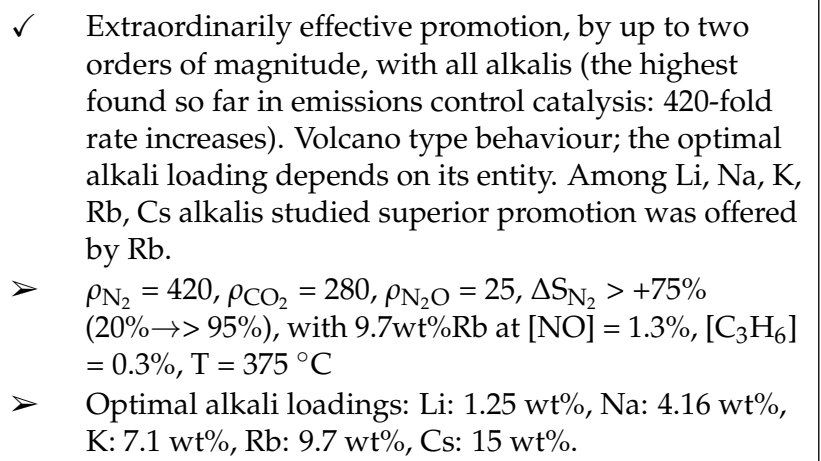 & $\begin{array}{l}{[15]} \\
{[61]} \\
{[21]} \\
{[22]}\end{array}$ \\
\hline
\end{tabular}


Table 4. Cont

\begin{tabular}{|c|c|c|c|c|c|}
\hline Reactants & Catalyst and (Promotion method applied) & Promoter & Reaction conditions & Promotion highlights and maximum achievements & Ref. \\
\hline $\mathrm{NO}, \mathrm{C}_{3} \mathrm{H}_{6}$ & $\begin{array}{c}0.5 \mathrm{wt} \% \mathrm{Pt} / \gamma-\mathrm{Al}_{2} \mathrm{O}_{3} \\
(\mathrm{CCP})\end{array}$ & Ва & $\begin{array}{c}\mathrm{T}=200-500{ }^{\circ} \mathrm{C} \\
{[\mathrm{NO}]=0-5 \%,\left[\mathrm{C}_{3} \mathrm{H}_{6}\right]=} \\
0-2 \% \\
\text { Ba loadings: } 0,3.5,9.7 \\
15.2,22.3 \mathrm{wt} \%\end{array}$ & 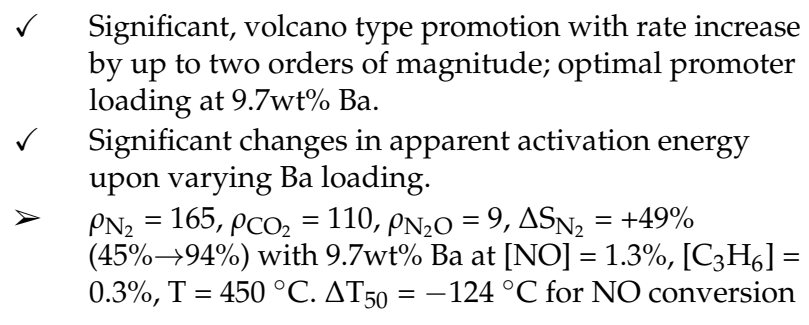 & $\begin{array}{l}{[62]} \\
{[63]}\end{array}$ \\
\hline $\mathrm{NO}, \mathrm{C}_{3} \mathrm{H}_{6}$ & $\begin{array}{c}0.5 \mathrm{wt} \% \mathrm{Rh} / \gamma-\mathrm{Al}_{2} \mathrm{O}_{3} \\
(\mathrm{CCP})\end{array}$ & $\mathrm{Na}$ & $\begin{array}{c}\mathrm{T}=200-550{ }^{\circ} \mathrm{C} \\
{[\mathrm{NO}]=0-1 \%,\left[\mathrm{C}_{3} \mathrm{H}_{6}\right]=} \\
0.1 \% \\
\text { Na loadings: } 0,1.8,3.0 \\
7.3,11.3 \mathrm{wt} \%\end{array}$ & 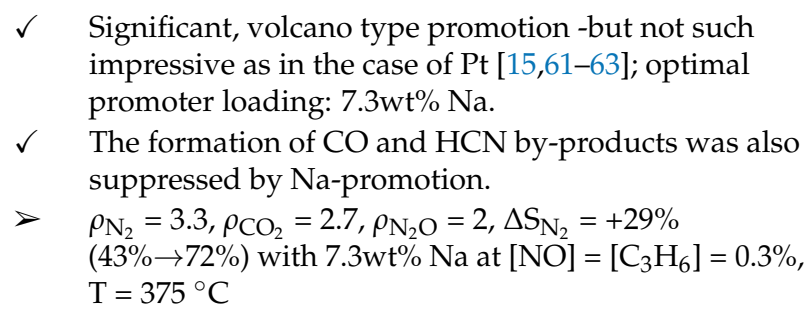 & [64] \\
\hline \multicolumn{6}{|c|}{ NO reduction by alkanes (NO + Alkane) } \\
\hline $\mathrm{NO}, \mathrm{CH}_{4}$ & $\begin{array}{c}0.5 \mathrm{wt} \% \mathrm{Pd} / \mathrm{YSZ} \\
(\mathrm{CCP})\end{array}$ & $\mathrm{Na}$ & $\begin{array}{c}\mathrm{T}=350-450{ }^{\circ} \mathrm{C} \\
{[\mathrm{NO}]=0-1.5 \%,\left[\mathrm{CH}_{4}\right]=} \\
0-20 \% \\
\text { Na loadings: } 0,0.017 \\
0.034,0.068,0.102 \mathrm{wt} \%\end{array}$ & $\begin{array}{l}\checkmark \quad \mathrm{Pd} \text { by itself is an effective catalyst for } \mathrm{NO} \text { reduction } \\
\text { by } \mathrm{CH}_{4} \text {. Na induced only poisoning in the whole } \\
\text { region of [NO] and }\left[\mathrm{CH}_{4}\right] \text { concentrations studied; the } \\
\text { weak adsorption of } \mathrm{CH}_{4} \text { compared to that of } \mathrm{O}_{2} \text { and } \\
\text { the O-poisoning of } \mathrm{Pd} \text { surface due to the } \\
\text { strengthening of the } \mathrm{Pd}-\mathrm{O} \text { bond induced by } \mathrm{Na} \text {, } \\
\text { readily explains this behaviour. } \\
\text { Only Na-induced poisoning on the system } \\
\text { was obtained. }\end{array}$ & $\begin{array}{l}{[65]} \\
{[66]}\end{array}$ \\
\hline
\end{tabular}


Table 4. Cont.

\begin{tabular}{|c|c|c|c|c|c|}
\hline Reactants & Catalyst and (Promotion method applied) & Promoter & Reaction conditions & Promotion highlights and maximum achievements & Ref. \\
\hline \multicolumn{6}{|c|}{ NO reduction by $\mathrm{H}_{2}$ and/or $\mathrm{CO}\left(\mathrm{NO}+\mathrm{H}_{2}, \mathrm{NO}+\mathrm{H}_{2}+\mathrm{CO}\right)$ in the absence or presence of $\mathrm{O}_{2}$} \\
\hline $\mathrm{NO}, \mathrm{H}_{2}$ & $\begin{array}{c}\text { Pt film on }(\mathrm{Na}) \beta^{\prime \prime} \mathrm{Al}_{2} \mathrm{O}_{3} \text { solid electrolyte } \\
(\text { EPOC) }\end{array}$ & $\mathrm{Na}$ & $\begin{array}{c}\mathrm{T}=300-450{ }^{\circ} \mathrm{C} \\
{[\mathrm{NO}]=0-1.6 \%,\left[\mathrm{H}_{2}\right]=} \\
0-1 \% \\
\theta_{\mathrm{Na}}=0-12 \%\end{array}$ & $\begin{array}{l}\checkmark \quad \begin{array}{l}\text { Significant, volcano type, promotion effects of Na to } \\
\mathrm{NO}+\mathrm{H}_{2} / \mathrm{Pt} \text { catalytic system; optimal promoter }\end{array} \\
\text { coverage } \theta_{\mathrm{Na}} \sim 6 \% \\
\checkmark \quad \begin{array}{l}\text { Significant variations in the apparent activation } \\
\text { energy of the reaction. }\end{array} \\
>\quad \begin{array}{l}\rho_{\mathrm{N}_{2}}=30, \rho_{\mathrm{N}_{2} \mathrm{O}}=6, \Delta \mathrm{S}_{\mathrm{N}_{2}}=+40 \%(36 \rightarrow 75 \%) \text { with } \theta_{\mathrm{Na}} \\
\sim 6 \% \text { at }[\mathrm{NO}]=0.63 \%\left[\mathrm{H}_{2}\right]=0.3 \%, \mathrm{~T}=375{ }^{\circ} \mathrm{C}\end{array}\end{array}$ & [19] \\
\hline $\mathrm{NO}, \mathrm{H}_{2}, \mathrm{O}_{2}$ & $\begin{array}{c}1 \mathrm{wt} \% \mathrm{Pt} / \gamma-\mathrm{Al}_{2} \mathrm{O}_{3} \\
1 \mathrm{wt} \% \mathrm{Pt} / \mathrm{SiO}_{2} \\
(\mathrm{CCP})\end{array}$ & $\begin{array}{l}\mathrm{Na} \\
(\mathrm{Mo})\end{array}$ & $\begin{array}{c}\mathrm{T}=50-200{ }^{\circ} \mathrm{C} \\
{[\mathrm{NO}]=0.1 \%,\left[\mathrm{H}_{2}\right]=0.4 \%,} \\
{\left[\mathrm{O}_{2}\right]=6 \%} \\
\mathrm{Na}_{2} \mathrm{O}-\text { laodings: } 0,0.27,1, \\
5 \text { and } 10 \mathrm{wt} \%\end{array}$ & 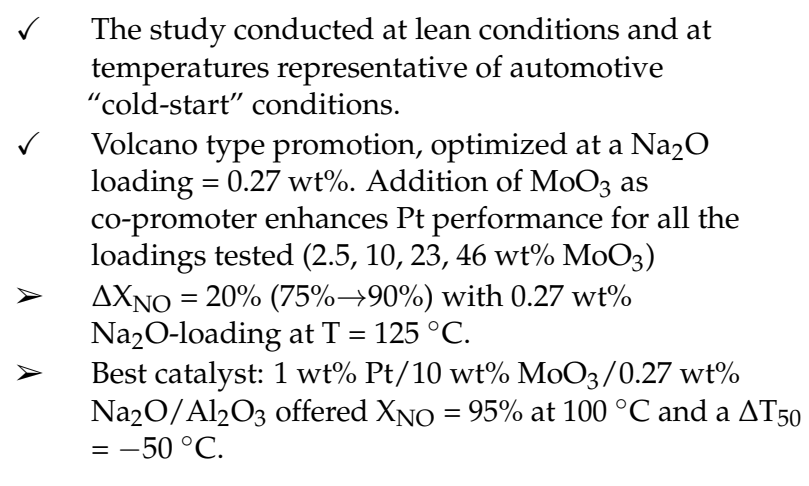 & [73] \\
\hline $\mathrm{NO}, \mathrm{H}_{2}, \mathrm{O}_{2}$ & $\begin{array}{c}1 \mathrm{wt} \% \mathrm{Pt} / \mathrm{ZSM}-5 \\
(\mathrm{CCP})\end{array}$ & $\begin{array}{l}\mathrm{Na}, \mathrm{K}, \mathrm{Cs} \\
\mathrm{Mg}, \mathrm{Ca}, \mathrm{Ba}\end{array}$ & $\begin{array}{c}\mathrm{T}=40-110{ }^{\circ} \mathrm{C} \\
{[\mathrm{NO}]=0.08 \%,\left[\mathrm{H}_{2}\right]=} \\
0.08-0.56 \%,\left[\mathrm{O}_{2}\right]=10 \% \mathrm{O}_{2} \\
\text { Na loadings: } 0,3,5,10,15 \\
\text { and } 20 \mathrm{wt} \%\end{array}$ & $\begin{array}{l}\checkmark \quad \begin{array}{l}\text { Optimum promotion achieved by Na. Optimal } \\
\text { promoter loading: 10-15 wt } \% \text { Na. }\end{array} \\
>\quad \mathrm{NO}_{x} \text { conversion }>90 \% \text { with a selectivity towards } \\
\mathrm{N}_{2} \sim 50 \% .\end{array}$ & [74] \\
\hline
\end{tabular}


Table 4. Cont.

\begin{tabular}{|c|c|c|c|c|c|}
\hline Reactants & Catalyst and (Promotion method applied) & Promoter & Reaction conditions & Promotion highlights and maximum achievements & Ref. \\
\hline $\begin{array}{c}\mathrm{NO}, \mathrm{H}_{2}, \mathrm{CO}, \\
\mathrm{O}_{2}\end{array}$ & $\begin{array}{c}0.5 \mathrm{wt} \% \mathrm{Pd} / \gamma-\mathrm{Al}_{2} \mathrm{O}_{3} \\
0.5 \mathrm{wt} \% \mathrm{Pd} / \gamma-\mathrm{Al}_{2} \mathrm{O}_{3}-\mathrm{TiO}_{2} \\
(\mathrm{CCP})\end{array}$ & K & $\begin{array}{c}\mathrm{T}=50-400{ }^{\circ} \mathrm{C} \\
{[\mathrm{NO}]=0.1 \%,[\mathrm{CO}]=} \\
0.25 \%,\left[\mathrm{H}_{2}\right]=0.75 \%,\left[\mathrm{O}_{2}\right] \\
=6 \% \mathrm{O}_{2} \\
\text { K loadings: } 0,0.1,0.25,0.5 \\
1.0 \text { and } 3.0 \mathrm{wt} \% \mathrm{~K}\end{array}$ & 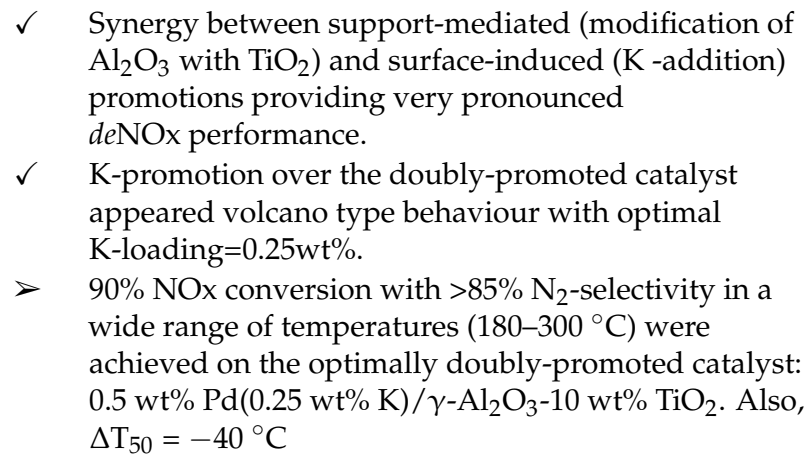 & [79] \\
\hline \multicolumn{6}{|c|}{ Direct NO decomposition } \\
\hline $\mathrm{NO}$ & $\begin{array}{c}(0.6-10 w t \%) \mathrm{Pd} / \gamma-\mathrm{Al}_{2} \mathrm{O}_{3} \\
(\mathrm{CCP})\end{array}$ & $\mathrm{Na}$ & $\begin{array}{c}\mathrm{T}=550-900{ }^{\circ} \mathrm{C} \\
{[\mathrm{NO}]=4 \% \text { in } \mathrm{He}} \\
\mathrm{Na} \text { loadings (as } \mathrm{NaOH}): 0, \\
1.3,4.3,6.5 \text { and } 13 \mathrm{wt} \% \\
\mathrm{NaOH}\end{array}$ & 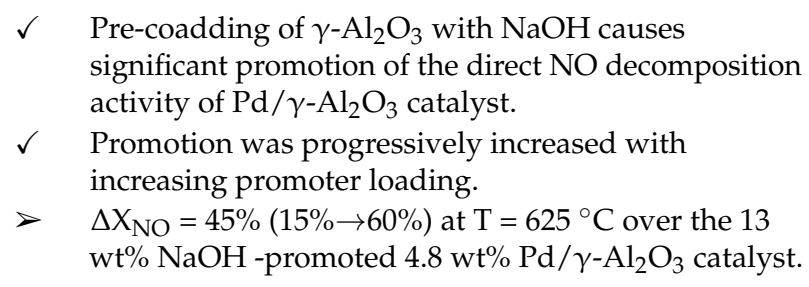 & [80] \\
\hline
\end{tabular}




\subsection{5. $\mathrm{N}_{2} \mathrm{O}$ Decomposition and/or Reduction}

It is well known that nitrous oxide $\left(\mathrm{N}_{2} \mathrm{O}\right)$ is absent in automotive engines exhausts gases, although this can be a by-product (in low concentrations) of the $\mathrm{NO}$ reduction reactions taking place in the after-treatment devices of cars (catalytic converters), primarily formed during the "cold start" and "intermediate temperature" periods. However, $\mathrm{N}_{2} \mathrm{O}$ is a powerful greenhouse gas (global warming potential $\sim 310$ ) and also the dominant stratospheric ozone-depleting gas nowadays. These account for the currently devoted high attention on the $\mathrm{N}_{2} \mathrm{O}$ emissions control. Besides mobile sources, other anthropogenic sources of $\mathrm{N}_{2} \mathrm{O}$ emissions involve stationary fuels combustion processes, agricultural activities and industrial plants (e.g., adipic and nitric acid plants) where it is produced in fairly high concentrations; the latter rationalizes why a major portion of $\mathrm{deN}_{2} \mathrm{O}$ studies concerns gas mixtures with relatively high $\mathrm{N}_{2} \mathrm{O}$ concentrations (ca. 0.1-1 vol.\%; Table 5), not actually mirror cars emissions.

\section{(i) Direct $\mathrm{N}_{2} \mathrm{O}$ decomposition}

No studies of electrochemical catalyst promotion (EPOC) were found in literature regarding the direct $\mathrm{N}_{2} \mathrm{O}$ decomposition. In the next paragraphs we summarize some examples of the CCP studies for this reaction.

The pronounced effect of electropositive promoters on the direct $\mathrm{N}_{2} \mathrm{O}$ decomposition performance (de- $\mathrm{N}_{2} \mathrm{O}$ ) of noble metals supported catalysts was demonstrated by several groups [81-85] (Table 5). In particular, Haber et al. [81] investigated the effect of $\mathrm{Li}, \mathrm{Na}, \mathrm{K}$ and $\mathrm{Cs}$ on $\mathrm{N}_{2} \mathrm{O}$ decomposition over $\mathrm{Rh}$ catalysts supported on alkali-modified $\mathrm{Al}_{2} \mathrm{O}_{3}$ carrier. They found that the deposition of alkali metals on $\mathrm{Al}_{2} \mathrm{O}_{3}$ support results in a notable increase of $\mathrm{Rh}$ dispersion, which improved de- $\mathrm{N}_{2} \mathrm{O}$ efficiency. In almost all cases the optimum promotional effects were obtained at $\sim 0.078 \mathrm{~mol} \%$ alkali (Table 5 ).

Parres-Esclaped et al. [82] studied the $\mathrm{N}_{2} \mathrm{O}$ decomposition over $\mathrm{Rh}$ catalysts supported either on bare $\gamma-\mathrm{Al}_{2} \mathrm{O}_{3}$ or on alkaline earth modified alumina ( $5 \mathrm{wt} \% \mathrm{Mg}$ - and Sr-doped $\gamma-\mathrm{Al}_{2} \mathrm{O}_{3}$ ). Enhanced $\mathrm{deN}_{2} \mathrm{O}$ performance was obtained with $\mathrm{Rh} /(\mathrm{Sr}) \mathrm{Al}_{2} \mathrm{O}_{3}$ catalysts, which achieved total $\mathrm{N}_{2} \mathrm{O}$ conversion at 300 and $350{ }^{\circ} \mathrm{C}$, in the absence and presence of $\mathrm{O}_{2}$, respectively, compared to 375 and $450{ }^{\circ} \mathrm{C}$ over un-promoted catalysts (Table 5). However, $\mathrm{Mg}$ addition was not beneficial to de $\mathrm{N}_{2} \mathrm{O} \mathrm{Rh} / \mathrm{Al}_{2} \mathrm{O}_{3}$ activity. The latter was attributed to the formation of magnesium aluminate, while the former was attributed to the enhanced Rh dispersion (determined by TEM) on account of the Sr-modifier.

Combined structural and surface promotion was applied by Konsolakis et al. [83] to facilitate the de $\mathrm{N}_{2} \mathrm{O}$ performance of $\mathrm{Pt} / \gamma-\mathrm{Al}_{2} \mathrm{O}_{3}$ catalyst. To this end, rare earth oxides $\left(\mathrm{CeO}_{2}, \mathrm{La}_{2} \mathrm{O}_{3}\right)$ were used as structural promoters of the $\gamma-\mathrm{Al}_{2} \mathrm{O}_{3}$ support and potassium $(\mathrm{K})$ as surface promoter of $\mathrm{Pt}$, providing a doubly-promoted $\mathrm{Pt}(\mathrm{K}) / \mathrm{Al}_{2} \mathrm{O}_{3}-\left(\mathrm{CeO}_{2}-\mathrm{La}_{2} \mathrm{O}_{3}\right)$ catalyst composite. The study was conducted on macro-structured, cordierite honeycomb monolith washcoated catalytic arrangements, suitable for practical implementations. The effect of $\mathrm{K}$-promoter was studied in the range of $0-2 \mathrm{wt} \% \mathrm{~K}$ loadings, while the impact of $\mathrm{O}_{2}, \mathrm{CO}$ and $\mathrm{H}_{2} \mathrm{O}$ in the feed stream was also investigated (Table 5). It was found that incorporation of $20 \mathrm{wt} \% \mathrm{CeO}_{2}-\mathrm{La}_{2} \mathrm{O}_{3}$ in the $\gamma-\mathrm{Al}_{2} \mathrm{O}_{3}$ support (ACZ) results in dramatic enhancement of the de $\mathrm{N}_{2} \mathrm{O}$ catalyst activity which is further improved by potassium addition. The promotional effects of $\mathrm{K}$ were found to monotonically increase upon increasing its loading on the structurally promoted $\mathrm{Pt} / \mathrm{ACZ}$ catalyst in the range of $0-2 \mathrm{wt} \%$ studied. As a result, the final doubly-promoted catalyst with $2 \mathrm{wt} \% \mathrm{~K}$ loading achieved $100 \% \mathrm{~N}_{2} \mathrm{O}$ conversion at a temperature of only $440{ }^{\circ} \mathrm{C}$; notably the bare $\mathrm{Pt} / \gamma-\mathrm{Al}_{2} \mathrm{O}_{3}$ did not exceed $\sim 35 \% \mathrm{~N}_{2} \mathrm{O}$ conversion even at $600{ }^{\circ} \mathrm{C}$ (Figure $14 \mathrm{a}$ ). In respect to the impact of $\mathrm{CO}, \mathrm{O}_{2}, \mathrm{H}_{2} \mathrm{O}$ co-feed, the authors found the following $\mathrm{deN}_{2} \mathrm{O}$ efficiency sequence in all promoted or non-promoted catalysts: $\mathrm{N}_{2} \mathrm{O}+\mathrm{CO}>>\mathrm{N}_{2} \mathrm{O}>\mathrm{N}_{2} \mathrm{O}+\mathrm{O}_{2}>\mathrm{N}_{2} \mathrm{O}+\mathrm{O}_{2}+\mathrm{CO}$ (Figure 14b). Water co-feed was detrimental to de $\mathrm{N}_{2} \mathrm{O}$ performance but in a partially reversible manner after its removal from the feed stream; the catalytic efficiency was totally restored by adding $\mathrm{H}_{2}$ into $\mathrm{N}_{2} \mathrm{O}+\mathrm{H}_{2} \mathrm{O}$ feed.

Papista et al. [84] studied the promoting impact of potassium addition to $\mathrm{Ir} / \gamma-\mathrm{Al}_{2} \mathrm{O}_{3}$ catalyst on $\mathrm{N}_{2} \mathrm{O}$ decomposition under both deficient and $\mathrm{O}_{2}$ excess conditions. Varying $\mathrm{K}$ loading in the range of $0-1 w t \%$, the authors found poisoning effect on the $\mathrm{deN}_{2} \mathrm{O}$ performance of iridium in the absence of oxygen in the feed. The opposite was true in the case of oxygen excess conditions; a 
pronounced promotion was recorded showing that $\mathrm{K}$ prohibits the oxygen-poisoning of the catalysts; the latter self-poisoning is a typical problem in $\mathrm{deN}_{2} \mathrm{O}$ catalytic chemistry, since the removal of the $\mathrm{N}_{2} \mathrm{O}$ decomposition-derived adsorbed oxygen on the catalyst surface is a key reaction step of the process. The alkali promotion found in the case of oxygen excess conditions follows volcano behaviour providing therefore an optimal promoter loading of $0.5 \mathrm{wt} \% \mathrm{~K}$, that resulted in a significant decrease of $\mathrm{T}_{50}$, equal to $\Delta \mathrm{T}_{50}=-80^{\circ} \mathrm{C}$ (Table 5). The effect of alkali on the adsorption properties of Ir involving strengthening of the $\mathrm{Ir}-\mathrm{O}$ bond of adsorbed $\mathrm{O}$ species with concomitant changes on the oxidation state of the metal was considered upon interpretation of the promotional and/or poisoning effects observed.

Finally, Goncalves and Figueiredo [85] studied the effect of potassium on the catalytic activity of $\mathrm{Pt}$ supported on activated carbon (ROX 0.8) for the simultaneous reduction of $\mathrm{NO}+\mathrm{N}_{2} \mathrm{O}$ mixtures. They found a synergistic effect between $\mathrm{K}$ and $\mathrm{Pt}$ which led to high activity at relatively low temperatures. For instance, at $350{ }^{\circ} \mathrm{C}$, a very stable and close to $100 \%$ conversion of both reactants was recorded over a $5 \mathrm{wt} \% \mathrm{~K} / 0.1 \mathrm{wt} \% \mathrm{Pt}$ catalyst, in opposite to the monometallic $0.5 \mathrm{wt} \% \mathrm{~K}$ or $0.1 \mathrm{wt} \% \mathrm{Pt}$ counterparts (Table 5). The latter showed significantly lower conversion activity of about $25 \%$ for NO and $90 \%$ and $0 \%$ for $\mathrm{N}_{2} \mathrm{O}$, respectively. The improved redox properties of the bimetallic $\mathrm{K} / \mathrm{Pt}$ formulation was responsible for this synergy on enhancing both deNO and $\mathrm{deN}_{2} \mathrm{O}$ reactions [85].

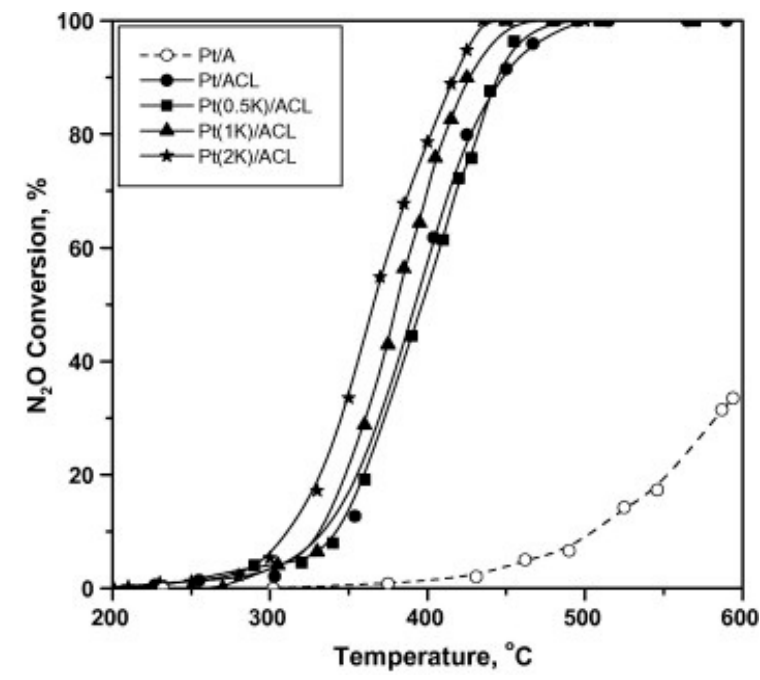

(a)

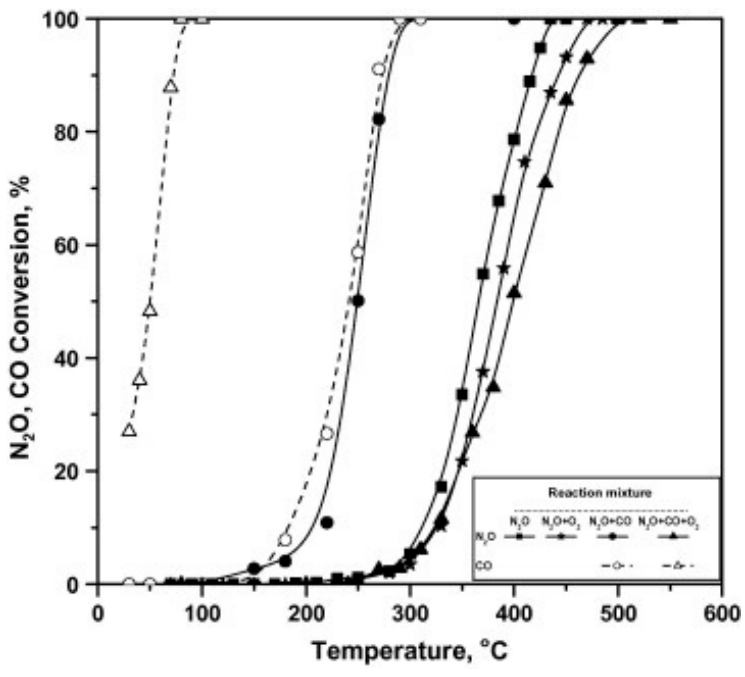

(b)

Figure 14. (a): $\mathrm{N}_{2} \mathrm{O}$ conversion profiles as a function of temperature (light-off curves) for bare $\mathrm{Pt} / \gamma-\mathrm{Al}_{2} \mathrm{O}_{3}$, structurally promoted $\mathrm{Pt} / \mathrm{ACL}$ and doubly-promoted $\mathrm{Pt}(\mathrm{K}) / \mathrm{ACL}$ catalysts under direct decomposition of $\mathrm{N}_{2} \mathrm{O}$; Feed: $0.1 \% \mathrm{~N}_{2} \mathrm{O}$, balance $\mathrm{He}$; $\mathrm{GHSV}=10,000 \mathrm{~h}^{-1}$. (b): $\mathrm{N}_{2} \mathrm{O}$ (and CO) conversion profiles obtained over the optimally doubly-promoted $\mathrm{Pt}(2 \mathrm{wt} \% \mathrm{~K}) / \mathrm{ACL}$ catalyst under direct $\mathrm{N}_{2} \mathrm{O}$ decomposition or $\mathrm{N}_{2} \mathrm{O}+\mathrm{CO}$ reactions in the absence or presence of $\mathrm{O}_{2}$, that is, under the feeds: $0.1 \%$ $\mathrm{N}_{2} \mathrm{O}$, balance He; $0.1 \% \mathrm{~N}_{2} \mathrm{O}+2 \% \mathrm{O}_{2}$, balance He; $0.1 \% \mathrm{~N}_{2} \mathrm{O}+0.1 \% \mathrm{CO}$, balance He; $0.1 \% \mathrm{~N}_{2} \mathrm{O}+0.1 \%$ $\mathrm{CO}+2 \% \mathrm{O}_{2}$, balance He. GHSV $=10,000 \mathrm{~h}^{-1}$. (Reprinted with permission from Ref. [83]; Copyright 2013, Elsevier).

(ii) $\mathrm{N}_{2} \mathrm{O}$ reduction by hydrocarbons

Very recently, the effect of alkali modifiers on another very important reaction related both to the TWC chemistry and $\mathrm{N}_{2} \mathrm{O}$ abatement, that is, the $\mathrm{N}_{2} \mathrm{O}$ reduction by hydrocarbons, was extensively studied by Pekridis et al. [25,86]. In particular, the role of potassium $(\mathrm{K})$ promoter on the surface and catalytic properties of $\mathrm{Pd} / \mathrm{Al}_{2} \mathrm{O}_{3}(\mathrm{CCP})$ catalysts for $\mathrm{N}_{2} \mathrm{O}$ reduction by alkanes $\left(\mathrm{CH}_{4}, \mathrm{C}_{3} \mathrm{H}_{8}\right)$ or alkenes $\left(\mathrm{C}_{3} \mathrm{H}_{6}\right)$ was investigated [86]. Potassium strongly enhanced the $\mathrm{N}_{2} \mathrm{O}$ reduction by propane or propene, resulting in notably lower $\mathrm{N}_{2} \mathrm{O}$ light off temperatures $\left(\sim 100^{\circ} \mathrm{C}\right)$ compared to the un-promoted catalyst (Table 5). However, a slight inhibition upon K-promotion was obtained when $\mathrm{CH}_{4}$ was used 
as a reducing agent, implying that the extent of K-promotion is strongly related with the nature of the reducing agent. A comprehensive surface characterization study, involving XPS, in situ DRIFT spectroscopy of CO adsorption and FTIR-pyridine adsorption, was undertaken to correlate the de- $\mathrm{N}_{2} \mathrm{O}$ performance with the catalyst surface characteristics. The results revealed that the electronic, acidic and structural properties of $\mathrm{Pd} / \mathrm{Al}_{2} \mathrm{O}_{3}$ catalyst can be substantially modified by potassium, which in turn affects the reactants chemisorption bonds and as a consequence the overall surface activity. Specifically, addition of $\mathrm{K}$ on $\mathrm{Pd} / \mathrm{Al}_{2} \mathrm{O}_{3}$ decreases the adsorption strength of electron-donor adsorbates, such as $\mathrm{C}_{3} \mathrm{H}_{8}$ and $\mathrm{C}_{3} \mathrm{H}_{6}$, enhancing the $\mathrm{N}_{2} \mathrm{O}$ adsorption through an electron transfer from metal sites to $\mathrm{N}_{2} \mathrm{O}$ antibonding orbitals. Both factors act synergistically towards increasing active sites for $\mathrm{N}_{2} \mathrm{O}$ adsorption/decomposition. However, in the case of $\mathrm{CH}_{4}, \mathrm{~K}$ enhances the adsorption strength of $\mathrm{N}_{2} \mathrm{O}$ and its dissociation products $\left(\mathrm{O}_{\mathrm{ads}}\right)$, at the expense of weakly bonded $\mathrm{CH}_{4}$, leading to poisoning by strongly bonded oxygen atoms.

In correlation with the above study, the EPOC concept (through a Pd-film electrocatalyst interfaced with $(\mathrm{K}) \beta^{\prime \prime} \mathrm{Al}_{2} \mathrm{O}_{3}$ solid electrolyte) was also used as a probe technique for exploring in detail the response of Pd metal to alkali $(\mathrm{K})$ promotion in the same reaction [25]. The obtained results matched very well the promotion characteristics of the previous CCP study that involved conventional highly dispersed catalysts, demonstrating experimentally again that electrochemical promotion is an efficient tool for a rapid investigation of the promoter effect on a catalytic system. The obtained information could be further used to design and optimize efficient and "smart" catalysts formulations.

The $\mathrm{N}_{2} \mathrm{O}$ reduction by propene was also studied by de Lucas-Consuegra et al. [87,88], over Pt-based electro-catalysts, electrochemically promoted by potassium by the use of a $(\mathrm{K}) \beta^{\prime \prime} \mathrm{Al}_{2} \mathrm{O}_{3}$ solid electrolyte. The authors found significant rate enhancement ratios $\left(\rho_{\max } \sim 10\right)$ at temperatures between $400-450{ }^{\circ} \mathrm{C}$ and a reaction mixture composition of $\mathrm{N}_{2} \mathrm{O} / \mathrm{C}_{3} \mathrm{H}_{6} / \mathrm{O}_{2}=1000 \mathrm{ppm} / 2000 \mathrm{ppm} / 2000 \mathrm{ppm}$ (Table 5). Potassium coverages (estimated by appropriate galvanostatic transients) higher than $\theta_{\mathrm{K}} \sim 70 \%$ were necessary in order to achieve such large rate enhancements. They also found that these pronounced promotional effects are similar for a wide range of $\mathrm{O}_{2}$ concentration in the reaction mixture (2000-7000 ppm), while at larger $\mathrm{O}_{2}$ concentrations ( $>9000 \mathrm{ppm}$ ) the promoting phenomena were practically vanished. A very significant observation of this work was also the demonstration that potassium addition strongly decreased the inhibiting effect of water vapor on the Pt-catalysed $\mathrm{N}_{2} \mathrm{O} / \mathrm{C}_{3} \mathrm{H}_{6} / \mathrm{O}_{2}$ catalytic system.

Overviewing the literature findings included in Section 3.1.5 and Table 5 the following general conclusions can emerge:

- Alkali addition on PGM catalysts typically promotes the direct $\mathrm{N}_{2} \mathrm{O}$ decomposition reaction (in the absence or presence of $\mathrm{O}_{2}$ in the feed stream) or its reduction by reducing agents.

- Among Pt, $\mathrm{Rh}$ and Ir catalysts, alkali-promotion of the $\mathrm{N}_{2} \mathrm{O}$ decomposition reaction was found to be very effective and superior on $\mathrm{Pt}$, less effective on Rh and detrimental (poisoning) on Ir; in the case of Ir, alkali-induced promotion was obtained only under excess oxygen conditions, which was attributed to changes on the oxidation state of the metal.

- Comparative EPOC and CCP studies of alkali promotion on the $\mathrm{N}_{2} \mathrm{O}$ reduction by the use of several reducing agents $\left(\mathrm{CH}_{4}, \mathrm{C}_{3} \mathrm{H}_{8}\right.$ and $\left.\mathrm{C}_{3} \mathrm{H}_{6}\right)$ demonstrated the great similarities on the output promotional characteristics of the two methods. 
Table 5. Electropositive promotion of PGMs-catalysed $\mathrm{N}_{2} \mathrm{O}$ decomposition and/or reduction reactions.

\begin{tabular}{|c|c|c|c|c|c|}
\hline Reactants & Catalyst and (Promotion method applied) & Promoter & Reaction conditions & Promotion highlights and maximum achievements & Ref. \\
\hline $\mathrm{N}_{2} \mathrm{O}$ & $\begin{array}{c}0.1 \mathrm{wt} \% \mathrm{Rh} / \gamma-\mathrm{Al}_{2} \mathrm{O}_{3} \\
(\mathrm{CCP})\end{array}$ & $\begin{array}{l}\mathrm{Li}, \mathrm{Na}, \mathrm{K}, \\
\quad \mathrm{Cs}\end{array}$ & $\begin{array}{c}\mathrm{T}=250-450{ }^{\circ} \mathrm{C} \\
{\left[\mathrm{N}_{2} \mathrm{O}\right]=1 \%} \\
\text { Alkali loadings (as alkali } \\
\text { oxides): } 0.033,0.066,0.078, \\
0.099 \mathrm{wt} \%\end{array}$ & $\begin{array}{ll}\checkmark \quad \text { Alkali addition enhanced Rh dispersion and thus } \\
\text { deN } \mathrm{N}_{2} \mathrm{O} \text { catalytic activity. Best promoter was Cs. } \\
\checkmark \quad \text { Volcano type promotion for all alkalis used; optimal } \\
\text { promoter loading } \sim 0.078 \mathrm{wt} \% \text { of alkali oxide. } \\
>\quad \Delta \mathrm{T}_{50}=-60{ }^{\circ} \mathrm{C} \text { for } \mathrm{Li} \text { and } \mathrm{Na} \text { promotion; } \Delta \mathrm{T}_{50}=-70 \\
{ }^{\circ} \mathrm{C} \text { for } \mathrm{K} \text { promotion; } \Delta \mathrm{T}_{50}=-90^{\circ} \mathrm{C} \text { for } \mathrm{Cs} \text { promotion }\end{array}$ & [81] \\
\hline $\begin{array}{l}\mathrm{N}_{2} \mathrm{O} \text {, } \\
\text { presence or } \\
\text { absence of } \\
\mathrm{O}_{2}\end{array}$ & $\begin{array}{c}0.5 \mathrm{wt} \% \mathrm{Rh} / \gamma-\mathrm{Al}_{2} \mathrm{O}_{3} \\
(\mathrm{CCP})\end{array}$ & $\mathrm{Mg}, \mathrm{Sr}$ & $\begin{array}{c}\mathrm{T}=250-450{ }^{\circ} \mathrm{C} \\
{\left[\mathrm{N}_{2} \mathrm{O}\right]=0.1 \% ;\left[\mathrm{N}_{2} \mathrm{O}\right]=} \\
0.1 \%+\left[\mathrm{O}_{2}\right]=5 \% \\
\text { Mg- or Sr-loading: } 5 \mathrm{wt} \%\end{array}$ & $\begin{array}{l}\checkmark \quad \begin{array}{l}\text { Significant promotion by } \mathrm{Sr} \text { either in the absence or in } \\
\text { the presence of } \mathrm{O}_{2} \text {. }\end{array} \\
\checkmark \quad \text { Small inhibition and marginal promotion by } \mathrm{Mg} \text { in } \\
\text { absence and presence of } \mathrm{O}_{2} \text {, respectively. } \\
>\quad \Delta \mathrm{T}_{50}=-45 \text { and }-50^{\circ} \mathrm{C} \text { in the absence and presence } \\
\text { of } \mathrm{O}_{2}, \text { respectively, with a Sr-loading }=5 \mathrm{wt} \% \text {. } \\
>\quad \Delta \mathrm{T}_{50}=+10 \text { and }-15^{\circ} \mathrm{C} \text { in the absence and presence } \\
\text { of } \mathrm{O}_{2} \text {, respectively, with a Mg-loading }=5 \mathrm{wt} \% \text {. }\end{array}$ & [82] \\
\hline $\begin{array}{c}\mathrm{N}_{2} \mathrm{O} \\
\text { presence or } \\
\text { absence of } \\
\mathrm{O}_{2}, \mathrm{CO}, \mathrm{H}_{2} \mathrm{O}\end{array}$ & $\begin{array}{c}0.5 \mathrm{wt} \% \mathrm{Pt} / \mathrm{Al}_{2} \mathrm{O}_{3}-\left(\mathrm{CeO}_{2}-\mathrm{La}_{2} \mathrm{O}_{3}\right) \\
(\mathrm{CCP})\end{array}$ & K & $\begin{array}{c}\mathrm{T}=200-600{ }^{\circ} \mathrm{C} \\
{\left[\mathrm{N}_{2} \mathrm{O}\right]=0.1 \% ;\left[\mathrm{N}_{2} \mathrm{O}\right]=} \\
0.1 \%+\left[\mathrm{O}_{2}\right]=2 \% ;\left[\mathrm{N}_{2} \mathrm{O}\right]= \\
0.1 \%+[\mathrm{CO}]=1 \% ; \\
{\left[\mathrm{N}_{2} \mathrm{O}\right]=0.1 \%+[\mathrm{CO}]=1 \%} \\
+\left[\mathrm{O}_{2}\right]=2 \% . \\
\text { K-loadings: } 0,0.5,1.0 \text { and } \\
2.0 \mathrm{wt} \%\end{array}$ & 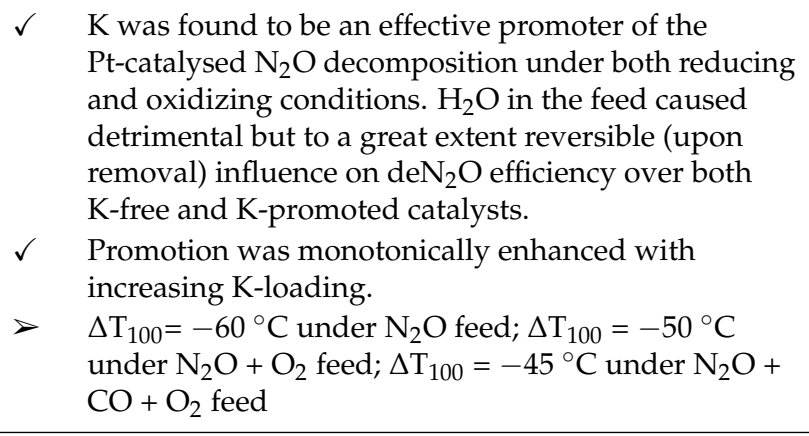 & [83] \\
\hline $\begin{array}{l}\mathrm{N}_{2} \mathrm{O} \\
\text { presence or } \\
\text { absence of } \\
\mathrm{O}_{2}\end{array}$ & $\begin{array}{c}0.5 \mathrm{wt} \% \mathrm{Ir} / \gamma-\mathrm{Al}_{2} \mathrm{O}_{3} \\
(\mathrm{CCP})\end{array}$ & K & $\begin{array}{c}\mathrm{T}=300-600{ }^{\circ} \mathrm{C} \\
{\left[\mathrm{N}_{2} \mathrm{O}\right]=0.1 \% ;\left[\mathrm{N}_{2} \mathrm{O}\right]=} \\
0.1 \%+\left[\mathrm{O}_{2}\right]=2 \% \\
\mathrm{~K} \text {-loadings: } 0,0.25,0.5 \\
\quad \text { and } 1.0 \mathrm{wt} \%\end{array}$ & $\begin{array}{l}\checkmark \quad \mathrm{K} \text { induces poisoning effects on the Ir-catalysed } \mathrm{N}_{2} \mathrm{O} \\
\text { decomposition at } \mathrm{O}_{2} \text {-deficient conditions. } \\
\checkmark \quad \text { In opposite, } \mathrm{K} \text { is an effective promoter under } \mathrm{O}_{2} \\
\text { excess conditions; volcano type promotion with an } \\
\text { optimal K-loading equal to } 0.5 \mathrm{wt} \% \mathrm{~K} \text {. } \\
>\quad \Delta \mathrm{T}_{50}=-80{ }^{\circ} \mathrm{C} \text { under }\left[\mathrm{N}_{2} \mathrm{O}\right]=0.1 \%+\left[\mathrm{O}_{2}\right]=2 \% \text { and } \\
0.5 \mathrm{wt} \% \mathrm{~K} \text { loading. }\end{array}$ & [84] \\
\hline
\end{tabular}


Table 5. Cont

\begin{tabular}{|c|c|c|c|c|c|}
\hline Reactants & Catalyst and (Promotion method applied) & Promoter & Reaction conditions & Promotion highlights and maximum achievements & Ref. \\
\hline $\mathrm{N}_{2} \mathrm{O}, \mathrm{NO}$ & $\begin{array}{c}(0.1 \text { and } 0.5 \mathrm{wt} \%) \mathrm{Pt} /(\mathrm{ROX} 0.8) \\
(\mathrm{CCP})\end{array}$ & K & $\begin{array}{c}\mathrm{T}=50-500{ }^{\circ} \mathrm{C} \\
{[\mathrm{NO}]=0.1 \% ;\left[\mathrm{N}_{2} \mathrm{O}\right]=} \\
0.05 \% ; \text { and }\left[\mathrm{N}_{2} \mathrm{O}\right]=0.05 \% \\
\quad+[\mathrm{NO}]=0.1 \% \\
\text { K-loading: } 3 \text { and } 5 \mathrm{wt} \%\end{array}$ & $\begin{array}{l}\checkmark \quad \mathrm{K} \text { addition simultaneously promotes the conversions } \\
\text { of } \mathrm{NO} \text { and } \mathrm{N}_{2} \mathrm{O} \text { at relatively low temperatures. } \\
100 \% \text { conversion of both } \mathrm{N}_{2} \mathrm{O} \text { and NO over } 5 \mathrm{wt} \% \\
\mathrm{~K} / 0.1 \mathrm{wt} \% \mathrm{Pt} / \mathrm{Al}_{2} \mathrm{O}_{3} \text { under }\left[\mathrm{N}_{2} \mathrm{O}\right]=0.05 \%+[\mathrm{NO}]= \\
1 \% \text { at } \mathrm{T}=350{ }^{\circ} \mathrm{C} \text {. }\end{array}$ & [85] \\
\hline $\begin{array}{l}\mathrm{N}_{2} \mathrm{O}+\mathrm{CH}_{4} \\
\mathrm{~N}_{2} \mathrm{O}+\mathrm{C}_{3} \mathrm{H}_{8} \\
\mathrm{~N}_{2} \mathrm{O}+\mathrm{C}_{3} \mathrm{H}_{6} \\
\text { presence or } \\
\text { absence of } \\
\quad \mathrm{O}_{2}\end{array}$ & $\begin{array}{c}2 \mathrm{wt} \% \mathrm{Pd} / \gamma-\mathrm{Al}_{2} \mathrm{O}_{3} \text {, and Pd film on } \\
(\mathrm{K}) \beta^{\prime \prime} \mathrm{Al}_{2} \mathrm{O}_{3} \text { solid electrolyte } \\
(\mathrm{CCP} \text { vs EPOC) }\end{array}$ & K & $\begin{array}{c}\mathrm{T}=100-500{ }^{\circ} \mathrm{C} \\
{\left[\mathrm{N}_{2} \mathrm{O}\right]=0.15 \%} \\
{\left[\mathrm{CH}_{4}\right]=0.6 \%} \\
{\left[\mathrm{C}_{3} \mathrm{H}_{8}\right]=0.2 \%} \\
{\left[\mathrm{C}_{2} \mathrm{H}_{6}\right]=0.2 \%} \\
\left(\left[\mathrm{O}_{2}\right]=3 \%\right) \\
\text { K-loadings: } 0,2.5,4.5,7.0, \\
9.0 \mathrm{wt} \%\end{array}$ & 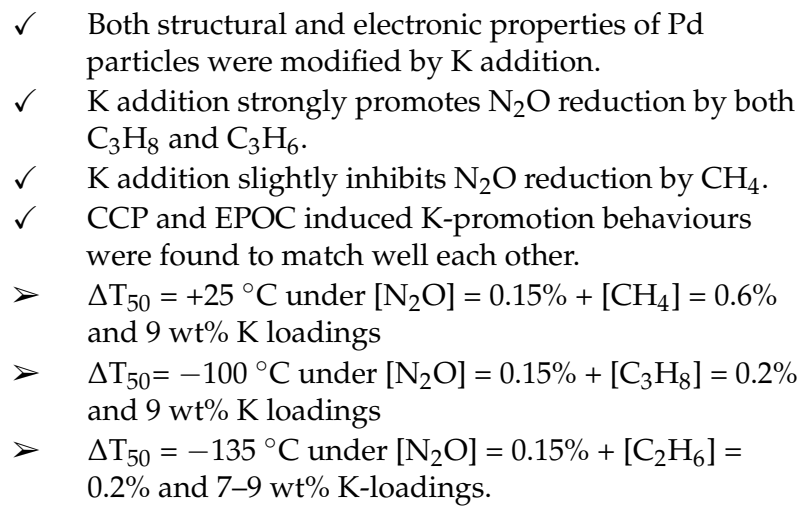 & $\begin{array}{l}{[25]} \\
{[86]}\end{array}$ \\
\hline $\begin{array}{c}\mathrm{N}_{2} \mathrm{O}, \mathrm{C}_{3} \mathrm{H}_{6} \\
\mathrm{O}_{2}\end{array}$ & $\begin{array}{c}\text { Pt film on }(\mathrm{K}) \beta^{\prime \prime} \mathrm{Al}_{2} \mathrm{O}_{3} \text { solid electrolyte } \\
(\mathrm{EPOC})\end{array}$ & K & $\begin{array}{c}\mathrm{T}=180-580^{\circ} \mathrm{C} \\
{\left[\mathrm{N}_{2} \mathrm{O}\right]=0.1 \%,\left[\mathrm{C}_{2} \mathrm{H}_{6}\right]=} \\
0.2 \% \\
{\left[\mathrm{O}_{2}\right]=0.2-1.0 \%} \\
\theta_{\mathrm{K}}=0-90 \%\end{array}$ & $\begin{array}{l}\checkmark \text { Strong K-induced promotion was observed. This was } \\
\text { progressively attenuated and finally reversed to } \\
\text { poisoning upon increasing } \mathrm{O}_{2} \text { in the feed stream. } \\
\text { K-promotion prevented deN } \mathrm{N}_{2} \mathrm{O} \text { activity of } \mathrm{Pt} \text { from the } \\
\text { poisoning effect of } \mathrm{H}_{2} \mathrm{O} \text {. } \\
>\quad \rho_{\mathrm{N}_{2} \mathrm{O}}=38.5, \rho_{\mathrm{C}_{3} \mathrm{H}_{6}}=1.2 \text { under }\left[\mathrm{N}_{2} \mathrm{O}\right]=0.1 \%+ \\
{\left[\mathrm{C}_{2} \mathrm{H}_{6}\right]=0.2 \%+\left[\mathrm{O}_{2}\right]=0.2 \%, \mathrm{~T}=450{ }^{\circ} \mathrm{C}, \theta_{\mathrm{K}} \sim 40 \%} \\
\left(\mathrm{~V}_{\mathrm{WR}}=-1 \mathrm{~V}\right)\end{array}$ & $\begin{array}{l}{[87]} \\
{[88]}\end{array}$ \\
\hline
\end{tabular}




\subsection{Electropositive Promotion of PGMs Operated Under Simulated Practical Conditions}

\subsubsection{Simulated TWC Conditions}

Given that alkalis and alkaline earths were found to strongly promote reactions related with the three-way catalytic (TWC) chemistry, testing of these new catalyst formulations at conditions that simulate automotive exhaust conditions was a reasonable consequence. To this end, Konsolakis et al. [89] studied the promotional effects of $\mathrm{Na}$ on $\mathrm{Pt} / \gamma-\mathrm{Al}_{2} \mathrm{O}_{3}$ catalysts operated under simulated exhaust conditions at the stoichiometric point (SP), that is, at the value equal to 1 of the stoichiometric number $(S)$, calculated as:

$$
\mathrm{S}=\left(2\left[\mathrm{O}_{2}\right]+[\mathrm{NO}]\right) /\left([\mathrm{CO}]+9\left[\mathrm{C}_{3} \mathrm{H}_{6}\right]\right)
$$

using a feed mixture consisting (v/v) 1000 ppm NO + 1067 ppm $\mathrm{C}_{3} \mathrm{H}_{6}+7000$ ppm CO +7800 ppm $\mathrm{O}_{2}$.

A series of Na-promoted $\mathrm{Pt} / \gamma-\mathrm{Al}_{2} \mathrm{O}_{3}$ catalysts were tested under these conditions at temperatures from $200-500{ }^{\circ} \mathrm{C}$ typical of TWCs. Typical results of the promoter effect on the overall $\mathrm{NO}, \mathrm{CO}$ and $\mathrm{C}_{3} \mathrm{H}_{6}$ conversions and selectivity obtained at $400{ }^{\circ} \mathrm{C}$, are shown in Figure 15 . The conversions of all three pollutants, $\mathrm{NO}, \mathrm{CO}$ and $\mathrm{C}_{3} \mathrm{H}_{6}$, reach $100 \%$ at sodium contents $>4.2 \mathrm{wt} \%$. In addition, $\mathrm{Na}$ promoter causes a significant decrease in the light off temperature of $\sim 100{ }^{\circ} \mathrm{C}$, together with significant improvements $(\sim 75 \%)$ in $\mathrm{N}_{2}$-selectivity (Table 6$)$. The promotional effect was attributed to the modified relative adsorption strengths of reactants and reaction intermediates, as explained above in the previous sections [89].

In a similar motive, Macleod et al. [90,91] studied the $\mathrm{Na}$ promotion of $\mathrm{Pd} / \gamma-\mathrm{Al}_{2} \mathrm{O}_{3}$ and $\mathrm{Rh} / \gamma-\mathrm{Al}_{2} \mathrm{O}_{3}$ catalysts operated under simulated TWC conditions over a range of stoichiometries from fuel rich to fuel lean conditions $(0.90<\mathrm{S}<1.1)$. They observed significantly different responses of $\mathrm{Na}$ addition in the two cases (Table 6). $\mathrm{Na}$ addition to $\mathrm{Pd} / \gamma-\mathrm{Al}_{2} \mathrm{O}_{3}$ significantly improves its overall performance: although the recorded promotional effects were not as high as those observed in Reference [89] for Na-promoted $\mathrm{Pt} / \gamma-\mathrm{Al}_{2} \mathrm{O}_{3}$, results were again very spectacular.

A $7 \mathrm{wt} \% \mathrm{Na}$ loading (optimal promoter loading for the conditions used) offered a $\sim 50{ }^{\circ} \mathrm{C}$ lower light off temperature than the unpromoted $\mathrm{Pd}$ when tested under stoichiometric feed conditions

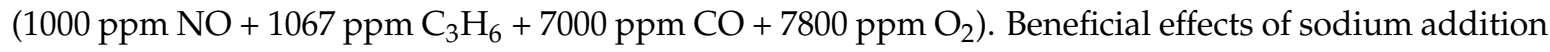
were also recorded under both fuel rich and fuel lean conditions (Table 6). In the former case, Na was found to prevent catalyst poisoning by carbon deposition therefore maintaining high NO conversions, while in the latter case $\mathrm{Na}$ reduced the formation of $\mathrm{N}_{2} \mathrm{O}$ therefore leading to enhanced selectivities toward $\mathrm{N}_{2}$. However, the authors found that $\mathrm{Na}$ addition to $\mathrm{Rh}$ has a detrimental effect causing severe activity poisoning and $\mathrm{N}_{2}$-selectivity reduction over the greater part of the temperature interval of 200-400 ${ }^{\circ} \mathrm{C}$ investigated [92]. It was attributed to the enhanced oxygen adsorption on the Rh active sites at the expense of the hydrocarbon, whilst in the case of Pd the beneficial effects were considered as a consequence of Na-promoted NO dissociation, together with inhibition of self-poisoning due to excessive propene adsorption [91]. It is worth noting that $\mathrm{NO}$ dissociative chemisorption takes place spontaneously on $\mathrm{Rh}$ but not on $\mathrm{Pd}$.

Tanaka et al. [92] have also reported the beneficial effects of the addition of a small amount of $\mathrm{Na}_{2} \mathrm{O}$ to $(1.67 \mathrm{wt} \% \mathrm{Pt})\left(12.3 \mathrm{wt} \% \mathrm{MoO}_{3}\right) / \mathrm{SiO}_{2}$ catalysts investigated under simulated exhaust from automobile engine and three-way behaviour around the stoichiometric point (SP). They found that the active window of SP for the Na-promoted $\mathrm{PtMoNa} / \mathrm{SiO}_{2}$ catalyst is wider than that of the Na-free counterpart, that is, $\mathrm{PtMo} / \mathrm{SiO}_{2}$ and $\mathrm{Pt} / \mathrm{SiO}_{2}$ catalysts (Table 6). The observed improvements were attributed to the wider redox ratio window and to the depressed (by Mo and $\mathrm{Na}$ ) oxidation of Pt, even under oxygen excess. 


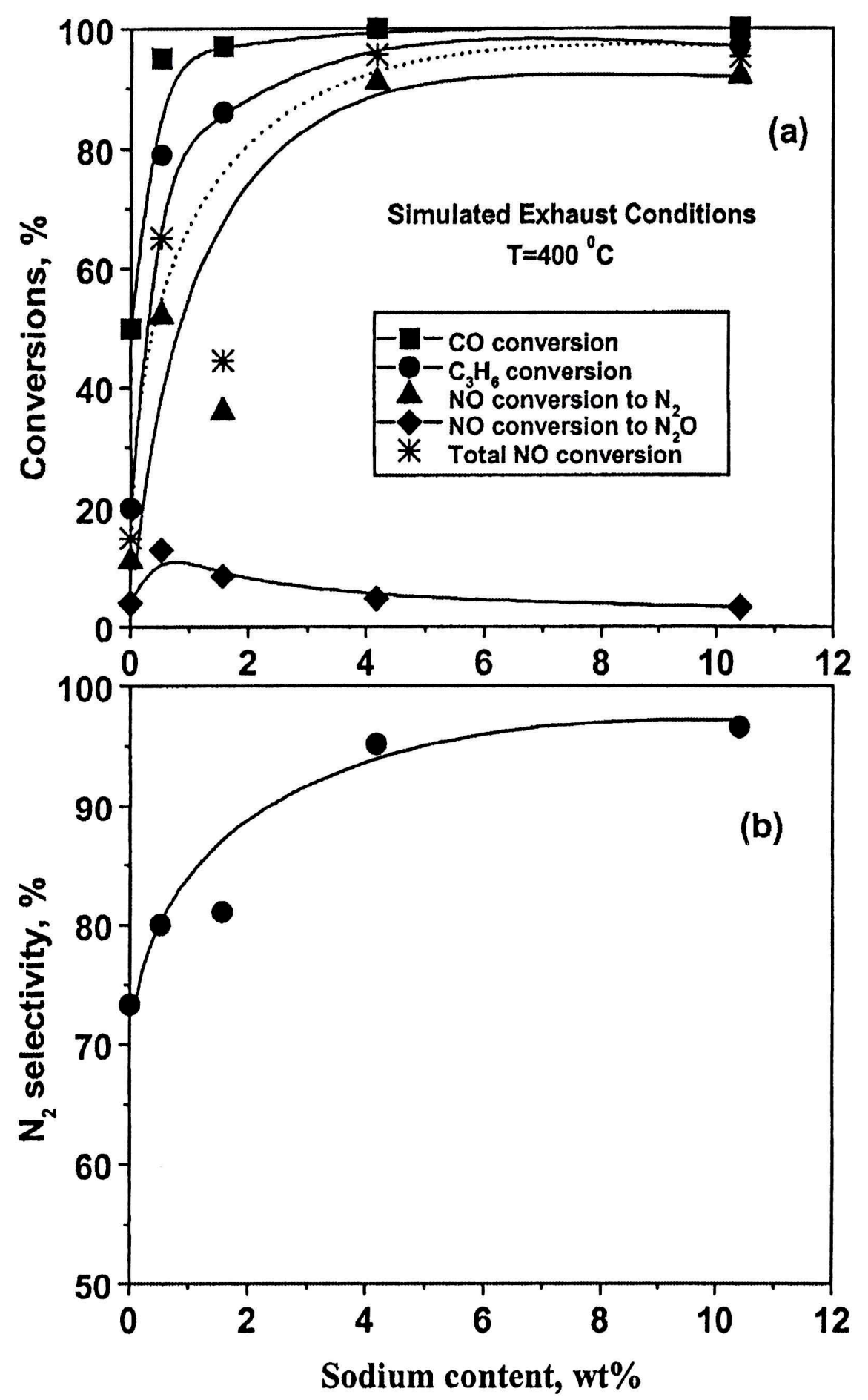

Figure 15. Testing Na-promoted $\mathrm{Pt} / \gamma-\mathrm{Al}_{2} \mathrm{O}_{3}$ catalysts at simulated exhaust conditions of conventional

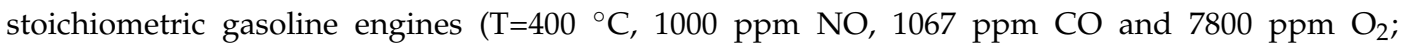
$\mathrm{F}_{\mathrm{t}}=80 \mathrm{~cm}^{3} \mathrm{STP} / \mathrm{min} ; \mathrm{m}_{\mathrm{cat}}=8 \mathrm{mg}$ ). Effect of $\mathrm{Na}$ loading on reactants conversions (a) and selectivity towards $\mathrm{N}_{2}$ (b). (Reprinted with permission from Ref. [89]; Copyright 2000, Elsevier).

Shinjon et al. [93] have investigated the effect of an alkaline earth (Ba) modifier on the catalytic activity of $\mathrm{Pt} / \gamma-\mathrm{Al}_{2} \mathrm{O}_{3}$ and $\mathrm{Rh} / \gamma-\mathrm{Al}_{2} \mathrm{O}_{3}$ catalysts under simulated automotive exhaust conditions at the stoichiometric point $\left(1 \% \mathrm{CO}, 0.3 \% \mathrm{H}_{2}, 0.1 \% \mathrm{C}_{3} \mathrm{H}_{6}, 0.1 \% \mathrm{NO}, 0.75 \% \mathrm{O}_{2}, 3 \% \mathrm{H}_{2} \mathrm{O}, 12 \% \mathrm{CO}_{2}\right)$. They found that the TWC-performance of $\mathrm{Pt} / \gamma-\mathrm{Al}_{2} \mathrm{O}_{3}$ catalysts was improved by Ba, offering $\sim 30{ }^{\circ} \mathrm{C}$ lower light off temperatures compared to those for the un-promoted catalysts (Table 6). However, the overall 
performance of Rh catalysts was deteriorated with Ba addition. It was attributed to the fact that Ba addition to Pt catalysts suppressed the strong hydrocarbon chemisorption, enhancing simultaneously the oxygen adsorption. On the other hand, Ba addition to Rh catalysts results in strong adsorption of oxygen species, suppressing hydrocarbon chemisorption and thus the reaction between them.

Kobayashi et al. [94] investigated the influence of $\mathrm{Ba}$ and Sr alkaline earth metals on a commercial Pd-only TWC catalyst ( $\mathrm{Pd} / \mathrm{Al}_{2} \mathrm{O}_{3}$-based TWC catalyst of N.E. ChemCat Corp.). Improved three-way catalytic performance was obtained regarding $\mathrm{CO}$ and $\mathrm{NO}_{\mathrm{x}}$ conversions (Table 6). The enhanced basicity and the electron-donation ability of these basic elements were considered to play significant role in the improvement of TWC performance. A higher electron density around $\mathrm{Pd}^{(\mathrm{II})}$ was revealed by XPS measurements in the Ba-promoted $\mathrm{Pd} / \mathrm{Al}_{2} \mathrm{O}_{3}$ catalyst in comparison with the Ba-free counterpart. The stabilization of $\mathrm{PdO}$ that may suppress palladium species sintering and the electron enrichment palladium particles that endows $\mathrm{Pd}$ to behave like $\mathrm{Rh}$ were concluded as the main promoting factors in this study [94].

A NO-free gas mixture of $\mathrm{CO}, \mathrm{C}_{3} \mathrm{H}_{6}, \mathrm{H}_{2}, \mathrm{O}_{2}, \mathrm{CO}_{2}$ and $\mathrm{H}_{2} \mathrm{O}$, simulating two-stroke motorcycle emissions (Table 6), was considered by Lee and Chen [30] for the investigation of the impact of $\mathrm{Na}_{2} \mathrm{O}$ and $\mathrm{K}_{2} \mathrm{O}$ addition on a $0.4 \mathrm{wt} \% \mathrm{Pt} / \gamma-\mathrm{Al}_{2} \mathrm{O}_{3}$ catalyst operated at $150-450{ }^{\circ} \mathrm{C}$ under stoichiometric and oxygen-deficient conditions (by varying the oxygen to reductants stoichiometric number; $\mathrm{S}=1,0.31$ and 0.17). Significant enhancements on the $\mathrm{CO}$ and $\mathrm{C}_{3} \mathrm{H}_{6}$ conversions were achieved by the addition of both alkalis under operation at the stoichiometric point $(\mathrm{S}=\mathrm{SP}=1)$; superior promotion was the one induced by potassium. Under $\mathrm{O}_{2}$-deficient conditions alkalis addition enhanced $\mathrm{CO}$ conversion but not that of propene, which was reduced. The presence of water in the gas mixture was found to have a strong positive impact on catalyst performance, in particular on K-promoted catalyst and for CO conversion (Table 6).

Yentekakis and co-workers $[95,96]$ developed monolithic type catalytic converters with a washcoat containing only one precious metal (Pt-only TWC), which was optimally promoted by Na. Catalytic performance tests of this novel TWC under simulated exhaust conditions in a wide temperature range $\left(150-500{ }^{\circ} \mathrm{C}\right)$ exhibited similar performance and even better $\mathrm{N}_{2}$ selectivity $(\sim 100 \%$ in the whole temperature range) compared to that of a commercial bimetallic ( $\mathrm{Pt} / \mathrm{Rh}$ )-TWC catalyst (Figure 16A, Table 6); notably, the aforementioned TWC had a 4.5-fold lower noble metal loading in comparison to the commercial one. These novel material formulation and design for TWCs is subjected to much lower production cost (use of only one noble metal at much lower loading, without the necessity of scarce $\mathrm{Rh}$ in their constitution) and cost-effective recycling.

Most recent tests of these novel TWCs at more severe temperature conditions ( $>800{ }^{\circ} \mathrm{C}$ ) have also shown a significant resistance to deactivation (Figure 16B) [97,98], implying that the promoter phase $(\mathrm{Na})$ does not practically escape from the catalyst composite even at very high temperatures, due to its stabilization via the formation of new $\beta^{\prime}$ and $\beta^{\prime \prime}$ sodium-alumina phases as verified by TEM and XRD studies $[97,98]$. These phases, in direct interaction with the active phase (Pt), then act as a spontaneous (thermal diffusion driven) Na promoter source during TWC operation causing permanent promotion [97,98].

Overviewing the literature findings presented in this section and in Table 6, one can readily conclude that electropositive promotion of PGM-catalysts under simulated automotive exhaust conditions follows, in general terms, the promotional characteristics corresponding to the simple (model) reactions of the complex reactions scheme taking place into the converter. However, other possible synergistic or competitive interactions between the reactants and reactions' intermediates on a densely populated surface with all these competitive species can be at work affecting the overall performance. 



Figure 16. Three-way catalytic performance at $450{ }^{\circ} \mathrm{C}$ of "fresh" (A) and "aged" (B) TWC samples at simulated stoichiometric gasoline engines exhaust conditions $(0.1 \% \mathrm{NO}+0.7 \% \mathrm{CO}+0.1067 \%$ $\mathrm{C}_{3} \mathrm{H}_{6}+0.78 \% \mathrm{O}_{2}$, balanced with $\mathrm{He}$ at 1 bar; $\mathrm{F}_{\mathrm{t}}=3200 \mathrm{~cm}^{3}(\mathrm{STP}) / \mathrm{min}$ ). (Reproduced with permission from Ref. [98]; Copyright 2011, Elsevier). 
Table 6. Electropositive promotion of PGM-catalysts operated under simulated automotive exhaust conditions.

\begin{tabular}{|c|c|c|c|c|c|}
\hline Reactants & Catalyst and (promotion method applied) & promoter & Conditions & Promotion highlights and achievements & Ref. \\
\hline $\begin{array}{l}\mathrm{NO}, \mathrm{C}_{3} \mathrm{H}_{6} \\
\mathrm{CO}, \mathrm{O}_{2}\end{array}$ & $\begin{array}{c}0.5 \mathrm{wt} \% \mathrm{Pt} / \gamma-\mathrm{Al}_{2} \mathrm{O}_{3} \\
(\mathrm{CCP})\end{array}$ & $\mathrm{Na}$ & $\begin{array}{c}\mathrm{T}=200-500{ }^{\circ} \mathrm{C} \text { (at simulated TWC } \\
\text { conditions }) \\
{[\mathrm{NO}]=1000 \mathrm{ppm},[\mathrm{CO}]=7000 \mathrm{ppm},} \\
{\left[\mathrm{C}_{3} \mathrm{H}_{6}\right]=1067 \mathrm{ppm},\left[\mathrm{O}_{2}\right]=7800 \mathrm{ppm} ;(\text { at }} \\
\mathrm{S}=\mathrm{SP}=1) \\
\mathrm{w} / \mathrm{F}=6 \times 10^{-3} \mathrm{~g} \cdot \mathrm{s} / \mathrm{cm}^{3} \\
\text { Na loadings: } 0,0.52,1.57,4.18 \text { and } 10.4 \\
\mathrm{wt} \% \mathrm{Na}\end{array}$ & $\begin{array}{l}\checkmark \quad \text { Na promotes simultaneously the conversions of all } \\
\text { three pollutants, } \mathrm{CO}, \mathrm{C}_{3} \mathrm{H}_{6} \text { and } \mathrm{CO} \text { and enhances the } \\
\mathrm{N}_{2} \text {-selectivity at all promoter loadings used. } \\
\mathrm{CO}, \mathrm{C}_{3} \mathrm{H}_{6} \text { and } \mathrm{NO} \text { conversions reached } 100 \%, 100 \% \\
\text { and }>91 \% \text { at } \mathrm{T}=400{ }^{\circ} \mathrm{C} \text { and for Na-loadings } \\
>4.18 \mathrm{wt} \% \text {; the corresponding values on the } \\
\text { unpromoted } \mathrm{Pt} / \gamma-\mathrm{Al}_{2} \mathrm{O}_{3} \text { were only } 50,20 \text { and } 11 \% \text {. } \\
>\quad \Delta \mathrm{T}_{50}(\mathrm{CO})=-79{ }^{\circ} \mathrm{C}, \Delta \mathrm{T}_{50}(\mathrm{C} 3 \mathrm{H} 6)= \\
-77^{\circ} \mathrm{C}, \Delta \mathrm{T}_{50(\mathrm{NO})}=-93^{\circ} \mathrm{C} \text { and } \Delta \mathrm{S}_{\mathrm{N}_{2}}=+81 \% .\end{array}$ & [89] \\
\hline $\begin{array}{l}\mathrm{NO}, \mathrm{C}_{3} \mathrm{H}_{6} \\
\mathrm{CO}, \mathrm{O}_{2}\end{array}$ & $\begin{array}{c}0.5 \mathrm{wt} \% \mathrm{Pd} / \gamma-\mathrm{Al}_{2} \mathrm{O}_{3} \text { and } 0.5 \mathrm{wt} \% \\
\mathrm{Rh} / \gamma-\mathrm{Al}_{2} \mathrm{O}_{3} \\
(\mathrm{CCP})\end{array}$ & $\mathrm{Na}$ & $\begin{array}{c}\mathrm{T}=100-340{ }^{\circ} \mathrm{C} \text { (at simulated TWC } \\
\text { conditions) } \\
{[\mathrm{NO}]=1000 \mathrm{ppm},[\mathrm{CO}]=7000 \mathrm{ppm},} \\
{\left[\mathrm{C}_{3} \mathrm{H}_{6}\right]=1067 \mathrm{ppm}, 6970 \leq\left[\mathrm{O}_{2}\right] \leq 8630} \\
\mathrm{ppm} \\
\text { (around SP: } 0.9 \leq \mathrm{S} \leq 1.1) \\
\mathrm{w} / \mathrm{F}=15 \times 10^{-3} \mathrm{~g} \cdot \mathrm{s} / \mathrm{cm}^{3} \\
\text { Na loadings for Pd } / \mathrm{Al}_{2} \mathrm{O}_{3}: 0,1.8,3.5,7.0 \\
12.0 \mathrm{wt}^{2} \% \\
\text { Na loadings for } \mathrm{Rh} / \mathrm{Al}_{2} \mathrm{O}_{3}: 0,3.0 \text { and } 7.3 \\
\mathrm{wt} \% .\end{array}$ & 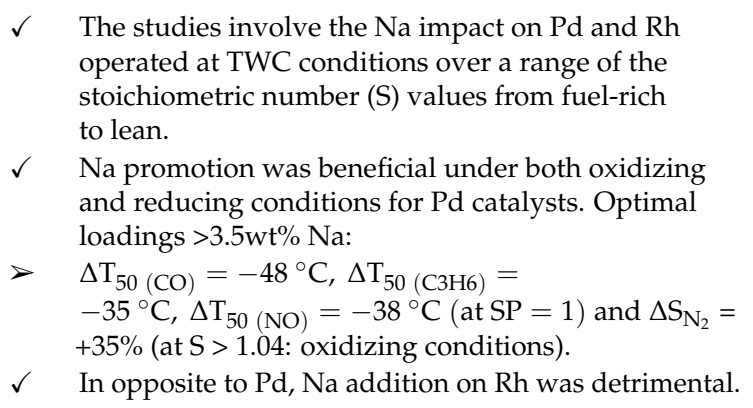 & $\begin{array}{l}{[90]} \\
{[91]}\end{array}$ \\
\hline $\begin{array}{l}\mathrm{NO}, \mathrm{C}_{3} \mathrm{H}_{6} \\
\mathrm{CO}, \mathrm{O}_{2}, \mathrm{H}_{2} \\
\mathrm{CO}_{2}, \mathrm{H}_{2} \mathrm{O}\end{array}$ & $\begin{array}{c}1.67 \mathrm{wt} \% \mathrm{Pt} / 12.3 \mathrm{wt} \% \mathrm{MoO}_{3}-\mathrm{SiO}_{2} \\
(\mathrm{CCP})\end{array}$ & $\mathrm{Na}_{2} \mathrm{O}$ & $\begin{array}{c}\mathrm{T}=100-600{ }^{\circ} \mathrm{C} \\
\mathrm{w} / \mathrm{F}=9.91 \times 10^{-3} \mathrm{~g} \cdot \mathrm{s} / \mathrm{cm}^{3} \\
\mathrm{Na}_{2} \mathrm{O} \text { loadings: } 0.05,0.1,1.0 \mathrm{wt} \% \\
\text { Simulated oxidizing feed, } \mathrm{S}=9.91: 4.3 \% \\
\mathrm{O}_{2}, 0.12 \% \mathrm{NO}, 800 \mathrm{ppm} \mathrm{C}_{3} \mathrm{H}_{6}, 0.12 \% \mathrm{CO} \\
400 \mathrm{ppm} \mathrm{H}_{2}, 12.3 \% \mathrm{CO}_{2}, 3 \% \mathrm{H}_{2} \mathrm{O} \\
\text { Simulated exhaust feed, } \mathrm{S}-\mathrm{scan}: \\
0.40-1.21 \% \mathrm{O}_{2}, 0.12 \% \mathrm{NO}, 490-62 \mathrm{ppm} \\
\mathrm{C}_{3} \mathrm{H}_{6}, 0.45-1.50 \% \mathrm{CO}, 0.15-0.50 \% \mathrm{H}_{2} \\
10.0 \% \mathrm{CO}_{2}, 3.0 \% \mathrm{H}_{2} \mathrm{O}\end{array}$ & $\begin{array}{l}\checkmark \text { Under nearly stoichiometric conditions, a wider redox } \\
\text { ratio window of } \mathrm{NO}_{\mathrm{x}} \text { conversion was obtained with } \\
\mathrm{PtMoNa} / \mathrm{SiO}_{2} \text { catalyst compared to } \mathrm{Pt} / \mathrm{SiO}_{2} \text {. } \\
\checkmark \quad \text { Under oxidizing conditions } \mathrm{PtMoNa} / \mathrm{SiO}_{2} \text { catalyst } \\
\text { resulted to a shift of all } \mathrm{CO}, \mathrm{C}_{3} \mathrm{H}_{6} \text { and } \mathrm{NO}_{\mathrm{x}} \\
\text { conversion profiles to higher temperatures. However, } \\
\text { a wider temperature window with higher } \mathrm{NOx} \\
\text { conversion was obtained. }\end{array}$ & [92] \\
\hline
\end{tabular}


Table 6. Cont.

\begin{tabular}{|c|c|c|c|c|c|}
\hline Reactants & Catalyst and (promotion method applied) & promoter & Conditions & Promotion highlights and achievements & Ref. \\
\hline $\begin{array}{l}\mathrm{NO}, \mathrm{C}_{3} \mathrm{H}_{6} \\
\mathrm{CO}, \mathrm{O}_{2}, \mathrm{H}_{2} \\
\mathrm{CO}_{2}, \mathrm{H}_{2} \mathrm{O}\end{array}$ & $\begin{array}{c}1.67 \mathrm{wt} \% \mathrm{Pt} / \gamma-\mathrm{Al}_{2} \mathrm{O}_{3} \\
0.9 \mathrm{wt} \% \mathrm{Rh} / \gamma-\mathrm{Al}_{2} \mathrm{O}_{3} \\
(\mathrm{CCP})\end{array}$ & $\mathrm{Ba}$ & $\begin{array}{c}\mathrm{T}=100-400{ }^{\circ} \mathrm{C} \text { (at simulated TWC } \\
\text { conditions) } \\
{[\mathrm{NO}]=1000 \mathrm{ppm},\left[\mathrm{C}_{3} \mathrm{H}_{6}\right]=334 \mathrm{ppm},} \\
{[\mathrm{CO}]=1 \%,\left[\mathrm{H}_{2}\right]=0.3 \%,\left[\mathrm{CO}_{2}\right]=12 \%} \\
{\left[\mathrm{H}_{2} \mathrm{O}\right]=3 \%,\left[\mathrm{O}_{2}\right]=0.75 \%} \\
\text { GHSV }=200000 \mathrm{~h}^{-1} \\
\text { Ba-loading: } 5.8,11.5,23 \text { and } 46 \mathrm{wt} \% \mathrm{Ba}\end{array}$ & $\begin{array}{l}\checkmark \quad \text { Ba addition significantly promotes } \mathrm{Pt} / \gamma-\mathrm{Al}_{2} \mathrm{O}_{3} \\
\text { activity under simulated exhaust conditions. The } \\
\text { opposite is true for } \mathrm{Rh} / \gamma-\mathrm{Al}_{2} \mathrm{O}_{3} \text {. } \\
\Delta \mathrm{T}_{50(\mathrm{NOx})}=-30^{\circ} \mathrm{C} \text { over } 46 \mathrm{wt} \% \text { Ba-promoted } \\
\mathrm{Pt} / \gamma-\mathrm{Al}_{2} \mathrm{O}_{3} \\
\Delta \mathrm{T}_{50(\mathrm{NOx})}=+15^{\circ} \mathrm{C} \text { over } 46 \mathrm{wt} \% \text { Ba-promoted } \\
\mathrm{Rh} / \gamma-\mathrm{Al}_{2} \mathrm{O}_{3}\end{array}$ & [93] \\
\hline $\begin{array}{l}\text { Exhaust gas } \\
\text { from an } \\
\text { automotive } \\
\text { engine }\end{array}$ & $\begin{array}{c}5 \mathrm{wt} \% \text { Pd-commercial TWC catalyst } \\
\text { supplied by N.E. ChemCat Corp. } \\
\text { (CCP) }\end{array}$ & $\mathrm{Ba}, \mathrm{Sr}, \mathrm{La}$ & $\begin{array}{c}\mathrm{T}=300-600{ }^{\circ} \mathrm{C} \\
\text { Real stoichiometric automotive engine } \\
\text { exhaust gas } \\
\text { GHSV }=68000 \mathrm{~h}^{-1} \\
\mathrm{Ba}, \text { Sr od La-loading: } 5 \mathrm{wt} \%\end{array}$ & $\begin{array}{l}\checkmark \quad \text { The TWC performance of the Pd-based commercial } \\
\text { catalyst was significantly improved by the addition of } \\
\text { Ba, Sr or La. } \\
\checkmark \quad \begin{array}{l}\text { The performance improvements followed the order: } \\
\text { Ba > Sr > La. }\end{array} \\
\checkmark \quad \begin{array}{l}\text { Alkaline earths promotion was related with the } \\
\text { stabilization of PdO phase and its electron } \\
\text { enrichment, which endows Pd to behave like Rh. }\end{array}\end{array}$ & [94] \\
\hline $\begin{array}{c}\mathrm{C}_{3} \mathrm{H}_{6}, \mathrm{CO} \\
\mathrm{H}_{2}, \mathrm{O}_{2}, \mathrm{CO}_{2} \\
\mathrm{H}_{2} \mathrm{O} \\
\text { (NO-free) }\end{array}$ & $\begin{array}{c}0.4 \mathrm{wt} \% \mathrm{Pt} / \gamma-\mathrm{Al}_{2} \mathrm{O}_{3} \\
(\mathrm{CCP})\end{array}$ & $\mathrm{Na}, \mathrm{K}$ & $\begin{array}{c}\mathrm{T}=150-450{ }^{\circ} \mathrm{C} \text { (simulated two-stroke } \\
\text { motorcycle emissions). } \\
{[\mathrm{CO}]=1-4.14 \%,\left[\mathrm{C}_{3} \mathrm{H}_{6}\right]=0.08-0.7 \%,} \\
{\left[\mathrm{O}_{2}\right]=0.96-0.9 \%,\left[\mathrm{H}_{2}\right]=0.2 \%,\left[\mathrm{CO}_{2}\right]=} \\
10 \%,\left[\mathrm{H}_{2} \mathrm{O}\right]=0 \text { or } 10 \% . \\
\text { Stoichiometric numbers studied } \mathrm{S}=1 \\
0.31,0.17 \\
\text { Na-loading: } 4.5 \mathrm{wt} \% ; \mathrm{K} \text {-loading: } 7.6 \mathrm{wt} \%\end{array}$ & 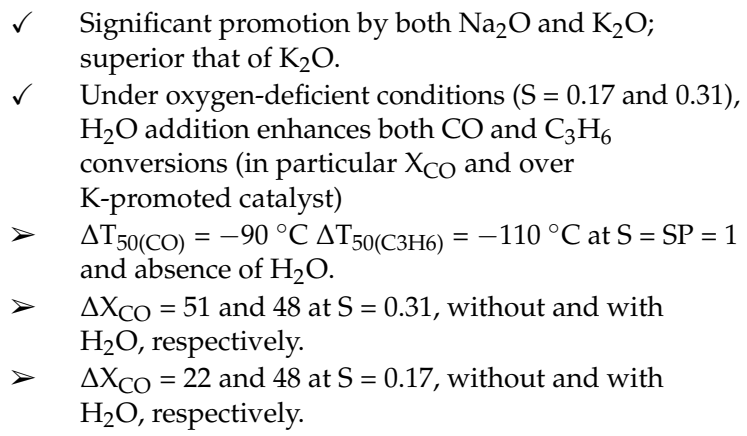 & [30] \\
\hline
\end{tabular}


Table 6. Cont.

\begin{tabular}{|c|c|c|c|c|c|}
\hline Reactants & Catalyst and (promotion method applied) & promoter & Conditions & Promotion highlights and achievements & Ref. \\
\hline $\begin{array}{c}\mathrm{NO}, \mathrm{C}_{3} \mathrm{H}_{6} \\
\mathrm{CO}, \mathrm{O}_{2}, \mathrm{CO}_{2} \\
\mathrm{H}_{2} \mathrm{O}\end{array}$ & $\begin{array}{c}0.1 \mathrm{wt} \% \\
\mathrm{Pt} /\left(\gamma-\mathrm{Al}_{2} \mathrm{O}_{3}-\mathrm{CeO}_{2}-\mathrm{La}_{2} \mathrm{O}_{3} \text {-cordierite }\right. \\
\text { monolith) versus a Commercial } \\
0.37 \mathrm{Pt} / 0.08 \mathrm{Rh}-\mathrm{TWC}(\mathrm{CCP})\end{array}$ & $\mathrm{Na}$ & $\begin{array}{c}\mathrm{T}=150-500{ }^{\circ} \mathrm{C} \text { (simulated TWC } \\
\text { conditions) } \\
{[\mathrm{NO}]=0.1 \%,[\mathrm{CO}]=0.7 \%,\left[\mathrm{C}_{3} \mathrm{H}_{6}\right]=} \\
0.1067 \%,\left[\mathrm{O}_{2}\right]=0.78 \%,\left[\mathrm{H}_{2} \mathrm{O}\right]=10 \%, \\
{[\mathrm{CO}]=10 \%} \\
\mathrm{GHSV}=50500 \mathrm{~h}^{-1} \\
\text { Na-loading: } 1 \text { and } 2 \mathrm{wt} \% \mathrm{Na} \text { (i.e., } 5 \text { and } \\
10 \mathrm{wt} \% \text { in the washcoat) }\end{array}$ & $\begin{array}{l}\checkmark \quad \text { The Na-promoted monometallic (Pt-only) TWC, with } \\
\text { 4.5-fold less PGMs loading compared to bimetallic } \\
\text { commercial one, exhibits similar performance with } \\
\text { the commercial and better } \mathrm{N}_{2} \text { selectivity }(\sim 100 \% \text { in } \\
\left.\text { the whole temperature range } 150-500^{\circ} \mathrm{C}\right) \text {. } \\
\checkmark \quad \begin{array}{l}\text { Marginal impact of } \mathrm{H}_{2} \mathrm{O} \text { and } \mathrm{CO}_{2} \text { on the performance } \\
\text { of Na/Pt-TWC. }\end{array} \\
\checkmark \quad \begin{array}{l}\text { A synergy between surface promoter (Na) and } \\
\text { structural promoters }\left(\mathrm{CeO}_{2}, \mathrm{La}_{2} \mathrm{O}_{3}\right) \text { was resulted, }\end{array} \\
\text { leading to this attractive promotion. } \\
\checkmark \quad \begin{array}{l}\text { Significant resistant to deactivation, even upon severe } \\
\text { aging }\left(>800{ }^{\circ} \mathrm{C}\right) \text {. }\end{array} \\
\checkmark \quad \begin{array}{l}\text { Na promotion remains at work even after aging due } \\
\text { to the formation of } \beta^{\prime}, \beta^{\prime \prime} \text { sodium alumina phases, }\end{array} \\
\text { which act as permanent spontaneous sources of Na } \\
\text { promoter species during TWC operation. }\end{array}$ & $\begin{array}{l}{[95]} \\
{[96]} \\
{[97]} \\
{[98]}\end{array}$ \\
\hline
\end{tabular}




\subsubsection{Oxygen Excess Conditions (Simulated Lean-Burn and Diesel Exhausts Gases)}

Some other EPOC studies regarding the electrochemical activation of Pt-based electrochemical catalysts for $\mathrm{NO}_{\mathrm{x}}$ reduction by propene under oxygen excess were performed by the groups of Vernoux and de-Lucas Consuegra. In this sense, Vernoux et al. observed a significant promotional effect of $\mathrm{Na}$ promoters electrochemically supplied from a NASICON solid electrolyte support [99]. The study was carried out under lean-burn conditions (oxygen excess, typical of Diesel engines). In such a system, electrochemical promotion is shown to strongly enhance both the catalytic activity and the selectivity to $\mathrm{N}_{2}$ (from $41 \%$ to $61 \%$ ) using very low overpotentials $\left(-100 \mathrm{mV}\right.$ ) at $300{ }^{\circ} \mathrm{C}$ (Table 7).

In the same line, the group of de Lucas Consuegra performed several EPOC studies by using $\mathrm{Na}$ and $\mathrm{K}$ promoters by means of $\left(\mathrm{Na}^{+}\right) \beta^{\prime} \mathrm{Al}_{2} \mathrm{O}_{3}$ and $\left(\mathrm{K}^{+}\right) \mathrm{AAl}_{2} \mathrm{O}_{3}$ solid electrolytes, respectively. First, they studied the effect of reaction temperature and $\mathrm{O}_{2}$ concentration in the feed stream on Pt catalysts promoted with Na species. Under lean burn conditions, at low reaction temperatures $\left(220^{\circ} \mathrm{C}\right)$, rate enhancement ratios up to 1.4 were observed for the NO reduction rate (Table 7) [100,101]. Nevertheless, as the reaction temperature increased, the promotional effect decreased, even resulting in a transition to a regime where the alkali metal induced poisoning. This progressive suppression of the promotional effect was due to an increase of the oxygen coverage on the Pt surface with the temperature, which led to a $\mathrm{C}_{3} \mathrm{H}_{6}$ adsorption inhibition. However, at all explored reaction temperatures, the presence of sodium ions induced a large increase of the $\mathrm{N}_{2}$ selectivity (up to $90 \%$ ), minimizing the $\mathrm{N}_{2} \mathrm{O}$ formation.

Regarding the effect of the $\mathrm{O}_{2}$ concentration, a study was performed at low temperatures $\left(240{ }^{\circ} \mathrm{C}\right)$ under $\mathrm{O}_{2}$ concentrations ranging from $0.5 \%$ to $5 \%$. The promotional effect of sodium on the overall catalytic activity for NO removal was progressively lowered with increasing oxygen concentrations, as a result of a strong inhibition of propene adsorption and a relative increase of the oxygen coverage. In all cases, the presence of sodium ions induced an increase in the nitrogen selectivity by promoting the NO adsorption and subsequent dissociation.

In a new investigation, de Lucas Consuegra et al. [102] studied for the first time the promotional effect of K (EPOC) under the presence of steam in the feed stream under lean burn conditions, as a new approach to the development of efficient catalysts under real working conditions of combustion engines. In this study, they demonstrated that the presence of K promoters could be practically used to decrease the inhibitory effect of water for the reduction of $\mathrm{NO}$ by propene. In addition, as previously demonstrated in other studies, they verified that the $\mathrm{K}$ species form stable nitrate species on the Pt surface. This discovery led to a new series of studies performed by the same research team, leading with the $\mathrm{NO}_{\mathrm{x}}$-storage and Reduction technology (NSR) by means of alkali-based Pt electrochemical catalysts.

Briefly, the NSR process was developed in the early 1990s by Toyota. It is based on the ability of alkali and alkali earth elements to store Nox in form of nitrites/nitrates under lean burn conditions (oxygen excess). Then, by the injection of extra fuel, the stored $\mathrm{NO}_{\mathrm{x}}$ are released and reduced with hydrocarbons, $\mathrm{CO}$ or $\mathrm{H}_{2}$, to produce $\mathrm{N}_{2}, \mathrm{CO}_{2}$ and $\mathrm{H}_{2} \mathrm{O}$. The alkali promoters function in two ways in these "smart" materials: first, they act as electronic promoters to enhance the NO oxidation to $\mathrm{NO}_{2}$ (which has been identified as the rate determining step of the overall process) and to store the $\mathrm{NO}_{2}$ produced in form of nitrites/nitrates (as previously demonstrated).

In these studies, de-Lucas Consuegra et al. demonstrated, for the very first time, the possibility to perform the NSR process via EPOC, by the use of Pt catalysts supported on $\mathrm{K}^{+}-\beta \mathrm{Al}_{2} \mathrm{O}_{3}$ solid electrolytes (to supply the K promoter species) $[103,104]$. The studies were performed under lean burn conditions and even under the presence of steam. The 2 main conclusions from these studies were:

- Potassium ions electrochemically transferred to the Pt catalyst play a double role in the NSR process, as a promoter for the NO oxidation reaction and as storage sites through the formation of potassium nitrates.

- The maximum yield of $\mathrm{Pt} /(\mathrm{K}) \mathrm{\beta Al}_{2} \mathrm{O}_{3}$ to effectively reduce $\mathrm{NO}_{\mathrm{x}}$ to $\mathrm{N}_{2}$ was obtained at $\mathrm{T}=300^{\circ} \mathrm{C}$ (Figure 17). This temperature is suitable for both, gasoline and diesel engines working under lean burn conditions. 


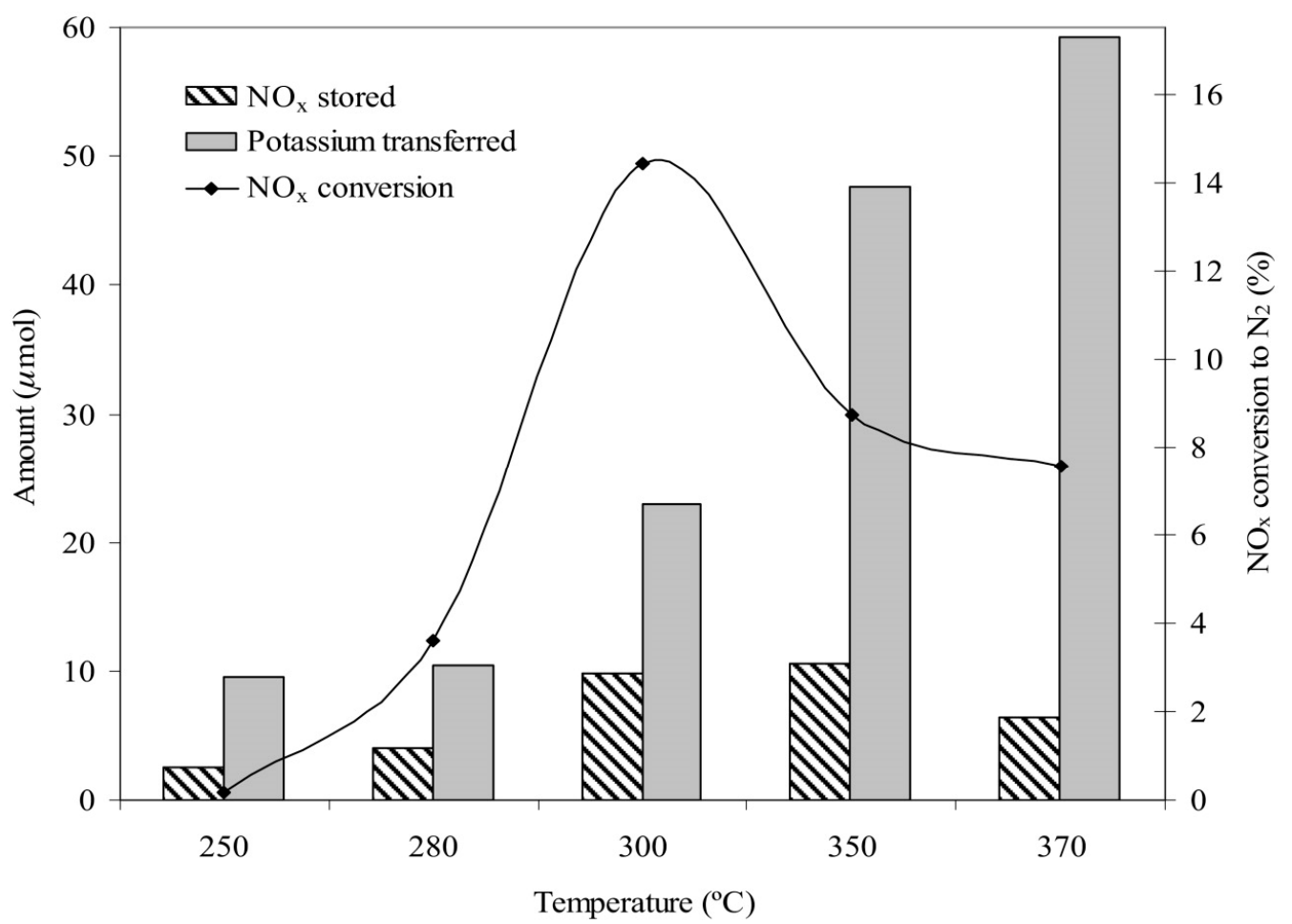

Figure 17. Influence of the reaction temperature on the amount of $\mathrm{NO}_{x}$ stored, potassium transferred and on the $\mathrm{NO}_{x}$ conversion to $\mathrm{N}_{2}$ during $\mathrm{NO}_{x}$ storage/reduction experiments. Lean phase $\left(\mathrm{NO} / \mathrm{C}_{3} \mathrm{H}_{6} / \mathrm{O}_{2}: 1000 \mathrm{ppm} / 1000 \mathrm{ppm} / 5 \% \mathrm{O}_{2}\right), 6 \mathrm{~min}$ of duration, $\mathrm{V}_{\text {cell }}=-1.5 \mathrm{~V}$. Rich phase $\left(\mathrm{NO} / \mathrm{C}_{3} \mathrm{H}_{6} / \mathrm{O}_{2}: 1000 \mathrm{ppm} / 1000 \mathrm{ppm} / 0.5 \% \mathrm{O}_{2}\right), 5 \mathrm{~min}$ of duration, $\mathrm{V}_{\text {cell }}=3 \mathrm{~V}$. Data was acquired in a $\mathrm{Pt} /(\mathrm{K}) \mathrm{\beta Al}_{2} \mathrm{O}_{3} / \mathrm{Au}$ galvanic cell (Reprinted with permission from Ref. [103]; Copyright 2011, Elsevier).

In respect to conventional highly dispersed catalysts and using CCP, early studies by Burch and Watling that involved the influence of a number of promoters, including alkalis (namely $\mathrm{K}$ and $\mathrm{Cs}$ ) and alkaline earths (namely $\mathrm{La}, \mathrm{Mg}, \mathrm{Ba}$ ), on the Pt-catalysed propene-SCR of $\mathrm{NO}_{\mathrm{x}}$ under lean-burn conditions have showed that addition of one of the following: $2.42 \mathrm{wt} \% \mathrm{~K}_{2} \mathrm{O}, 7.25 \mathrm{wt} \% \mathrm{Cs}_{2} \mathrm{O}, 7.93 \mathrm{wt} \%$ $\mathrm{BaO}, 2.07 \mathrm{wt} \% \mathrm{MgO}$ and $8.35 \mathrm{wt} \% \mathrm{La}_{2} \mathrm{O}_{3}$ in $1 \mathrm{wt} \% \mathrm{Pt} / \gamma-\mathrm{Al}_{2} \mathrm{O}_{3}$ catalyst results in suppression of the catalytic activity of $\mathrm{Pt}\left(\mathrm{NO}_{\mathrm{x}}\right.$ conversion efficiency) and to marginal effects on $\mathrm{N}_{2} / \mathrm{N}_{2} \mathrm{O}$ selectivity (Table 7) [105]. However, later studies of the de-Nox activity of supported Pt catalysts under lean burn conditions have shown very pronounced promotional effects by alkalis or alkaline earths: Vernoux et al. [106] and Yentekakis et al. [47], systematically investigated the resulted promotional effects of $\mathrm{Na}$ addition on supported $\mathrm{Pt} / \gamma-\mathrm{Al}_{2} \mathrm{O}_{3}$ catalysts $(\mathrm{CCP})$ during $\mathrm{NO}+$ propene + excess $\mathrm{O}_{2}$ as a function of the Na-loading, have shown significant beneficial effects of the alkali on both de-Nox activity and $\mathrm{N}_{2} / \mathrm{N}_{2} \mathrm{O}$ selectivity at low and intermediate Na-loadings (Table 7). In both studies, the effects (promoting or poisoning, depending on promoter loading) were understandable in terms of the influence of the alkali promoter on the relative adsorption strengths of reactants and intermediates on a highly populated surface with electrophilic and electrophonic adsorbates. In particular, Yentekakis et al. [47] demonstrated that Na acts beneficially to de-Nox process in a narrow window of $\mathrm{Na}$ loading (ca. $0-2.6 \mathrm{wt} \% \mathrm{Na}$ ), while overpromotion to the optimal value of $\sim 2.6 \mathrm{wt} \% \mathrm{Na}$ causes significant inhibition of the catalyst performance. The recorded promotional effects can be summarized as follows: Na widened the temperature window of the $\mathrm{C}_{3} \mathrm{H}_{6}+\mathrm{NO}+\mathrm{O}_{2}$ reaction towards lower temperatures by $\sim 50{ }^{\circ} \mathrm{C}$, accompanied by an enhancement in $\mathrm{N}_{2}$-selectivity by $\sim 40$ additional percentage points; the promotion is optimized at a sodium loading of $2.6 \mathrm{wt} \% \mathrm{Na}$ on the $0.5 \mathrm{wt} \% \mathrm{Pt} / \gamma-\mathrm{Al}_{2} \mathrm{O}_{3}$ catalyst (Figure 18). Obviously, the promoter loadings chosen by Burch and Watling were out from this optimal window, explaining the poisoning effects observed by the authors [105]. 


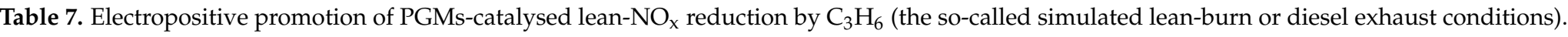

\begin{tabular}{|c|c|c|c|c|c|}
\hline reactants & Catalyst and (promotion method applied) & Promoter & Conditions & Promotion highlights and achievements & Ref. \\
\hline $\begin{array}{l}\mathrm{NO}, \mathrm{C}_{3} \mathrm{H}_{6} \\
\mathrm{O}_{2} \text { excess }\end{array}$ & $\begin{array}{l}\text { Pt film on NASICON solid electrolyte } \\
\text { (EPOC) }\end{array}$ & $\mathrm{Na}$ & $\begin{array}{c}\mathrm{T}=200-400{ }^{\circ} \mathrm{C} \\
{[\mathrm{NO}]=0.2 \%,\left[\mathrm{C}_{3} \mathrm{H}_{6}\right]=0.2 \%,\left[\mathrm{O}_{2}\right]=5 \%} \\
\text { Na coverage: non estimated (catalyst } \\
\text { potential } \mathrm{V}_{\mathrm{WR}} \text { is given) }\end{array}$ & $\begin{array}{l}\checkmark \quad \text { Na promotion induced strong enhancements on both } \\
\text { activity and } \mathrm{N}_{2} \text {-selectivity under lean-burn } \\
\text { conditions at quite low } \mathrm{T} \text {. } \\
>\quad \rho_{\mathrm{N}_{2}} \sim \rho_{\mathrm{CO}_{2}} \sim 1.7, \rho_{\mathrm{N}_{2} \mathrm{O}} \sim 1.1, \Delta \mathrm{S}_{\mathrm{N}_{2}}=+20 \% \\
(41 \% \rightarrow 61 \%) \text { at } \mathrm{T}=295^{\circ} \mathrm{C}, \Delta \mathrm{V}_{\mathrm{WR}}=-200 \mathrm{mV} \text {. }\end{array}$ & [99] \\
\hline $\begin{array}{l}\mathrm{NO}, \mathrm{C}_{3} \mathrm{H}_{6} \\
\mathrm{O}_{2} \text { excess }\end{array}$ & $\begin{array}{c}\text { Pt impregnated on }(\mathrm{Na}) \beta^{\prime \prime} \mathrm{Al}_{2} \mathrm{O}_{3} \text { solid } \\
\text { electrolyte } \\
\text { (EPOC) }\end{array}$ & $\mathrm{Na}$ & $\begin{array}{c}\mathrm{T}=220-300^{\circ} \mathrm{C} \\
{[\mathrm{NO}]=0.2 \%,\left[\mathrm{C}_{3} \mathrm{H}_{6}\right]=0.2 \%} \\
{\left[\mathrm{O}_{2}\right]=0.5,1 \text { and } 5 \%} \\
\theta_{\mathrm{Na}}=0-8 \%\end{array}$ & 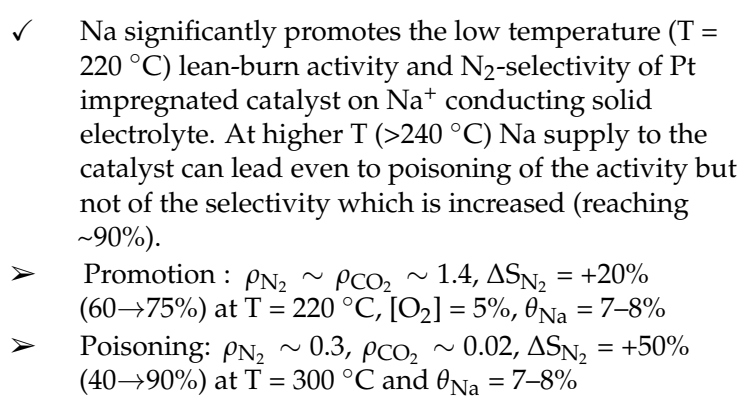 & $\begin{array}{l}{[100]} \\
{[101]}\end{array}$ \\
\hline $\begin{array}{l}\mathrm{NO}, \mathrm{C}_{3} \mathrm{H}_{6} \\
\mathrm{O}_{2} \text { excess, } \\
\mathrm{H}_{2} \mathrm{O}\end{array}$ & $\begin{array}{c}\text { Pt impregnated on }(\mathrm{K}) \mathrm{\beta Al}_{2} \mathrm{O}_{3} \text { solid } \\
\text { electrolyte } \\
\text { (EPOC) }\end{array}$ & K & $\begin{array}{c}\mathrm{T}=180-400{ }^{\circ} \mathrm{C} \\
{[\mathrm{NO}]=0.2 \%,\left[\mathrm{C}_{3} \mathrm{H}_{6}\right]=0.2 \%,\left[\mathrm{O}_{2}\right]=5 \%} \\
{\left[\mathrm{H}_{2} \mathrm{O}\right]=5 \%} \\
\theta_{\mathrm{K}}: \text { varying, non-estimated }\end{array}$ & $\begin{array}{l}\checkmark \quad \mathrm{K} \text { promotion depresses the inhibitory effect of } \mathrm{H}_{2} \mathrm{O} \\
\text { on the lean } \mathrm{NO}_{\mathrm{x}} \text { reduction by } \mathrm{C}_{3} \mathrm{H}_{6} \text {. } \\
\checkmark \quad \mathrm{K} \text { promoter species form stable nitrates on Pt surface, } \\
\text { thus can operate as a } \mathrm{NO}_{x} \text {-Storage Reduction } \\
\text { (NSR) species. }\end{array}$ & [102] \\
\hline $\begin{array}{l}\mathrm{NO}, \mathrm{C}_{3} \mathrm{H}_{6} \\
\mathrm{O}_{2} \text { excess }\end{array}$ & $\begin{array}{c}\text { Pt film on }(\mathrm{K}) \mathrm{BAl}_{2} \mathrm{O}_{3} \text { solid electrolyte } \\
(\mathrm{EPOC})\end{array}$ & K & $\begin{array}{c}\mathrm{T}=250-370^{\circ} \mathrm{C} \\
{[\mathrm{NO}]=0.1 \%,\left[\mathrm{C}_{3} \mathrm{H}_{6}\right]=0.1 \%,\left[\mathrm{O}_{2}\right]=5 \%} \\
\theta_{\mathrm{K}}: \text { varying, non-estimated }\end{array}$ & 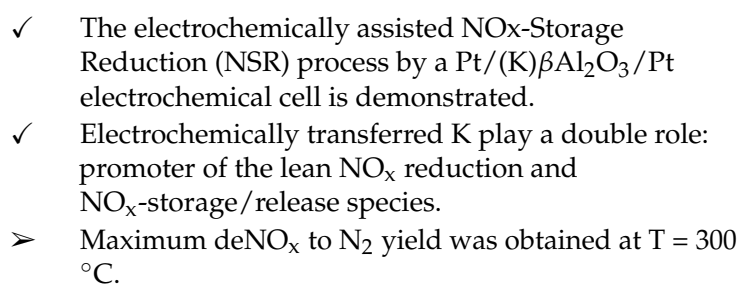 & $\begin{array}{l}{[103]} \\
{[104]}\end{array}$ \\
\hline
\end{tabular}


Table 7. Cont.

\begin{tabular}{|c|c|c|c|c|c|}
\hline reactants & Catalyst and (promotion method applied) & Promoter & Conditions & Promotion highlights and achievements & Ref. \\
\hline $\begin{array}{l}\mathrm{NO}, \mathrm{C}_{3} \mathrm{H}_{6} \\
\mathrm{O}_{2} \text { excess }\end{array}$ & $\begin{array}{c}1 \mathrm{wt} \% \mathrm{Pt} / \gamma-\mathrm{Al}_{2} \mathrm{O}_{3} \\
(\mathrm{CCP})\end{array}$ & $\begin{array}{c}\mathrm{K}, \mathrm{Cs}, \mathrm{La}, \\
\mathrm{Mg}, \mathrm{Ba}\end{array}$ & $\begin{array}{l}\mathrm{T}=200-500{ }^{\circ} \mathrm{C} \\
{[\mathrm{NO}]=0.1 \%,\left[\mathrm{C}_{3} \mathrm{H}_{6}\right]=0.1 \%,\left[\mathrm{O}_{2}\right]=5 \%} \\
\text { Alk-loadings: } \mathrm{A} / \mathrm{Pt}=10 / 1 \text { molar ratio }\end{array}$ & $\begin{array}{l}\checkmark \quad \text { Performance inhibition effects of alkaline materials } \\
\text { addition were found at the specific loading used for } \\
\text { each alkaline }(2.42,7.25,7.93,2.07 \text { and } 8.35 \mathrm{wt} \% \text { of } \\
\mathrm{K}_{2} \mathrm{O}, \mathrm{Cs}_{2} \mathrm{O}, \mathrm{BaO}, \mathrm{MgO} \text { and } \mathrm{La}_{2} \mathrm{O}_{3} \text {, respectively). }\end{array}$ & [105] \\
\hline $\begin{array}{l}\mathrm{NO}, \mathrm{C}_{3} \mathrm{H}_{6} \text { or } \\
\mathrm{C}_{3} \mathrm{H}_{8}, \mathrm{O}_{2} \\
\quad \text { excess }\end{array}$ & $\begin{array}{c}0.9 \mathrm{wt} \% \mathrm{Pt} / \gamma-\mathrm{Al}_{2} \mathrm{O}_{3} \\
(\mathrm{CCP})\end{array}$ & $\mathrm{Na}$ & $\begin{array}{c}\mathrm{T}=200-650{ }^{\circ} \mathrm{C} \\
{[\mathrm{NO}]=0.2 \%,[\mathrm{HC}]=0.2 \%\left(\mathrm{HC}: \mathrm{C}_{3} \mathrm{H}_{6} \text { or }\right.} \\
\left.\mathrm{C}_{3} \mathrm{H}_{8}\right),\left[\mathrm{O}_{2}\right]=5 \% \\
\text { GHSV }=20,000 \mathrm{~h}^{-1} \\
\text { Na-loadings: } 0.12,1 \text { and } 5 \mathrm{wt} \%\end{array}$ & 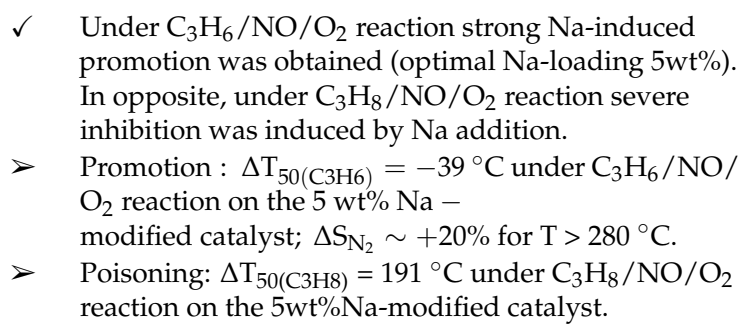 & [106] \\
\hline $\begin{array}{l}\mathrm{NO}, \mathrm{C}_{3} \mathrm{H}_{6} \\
\mathrm{O}_{2} \text { excess }\end{array}$ & $\begin{array}{c}0.5 \mathrm{wt} \% \mathrm{Pt} / \gamma-\mathrm{Al}_{2} \mathrm{O}_{3} \\
(\mathrm{CCP})\end{array}$ & $\mathrm{Na}$ & $\begin{array}{c}\mathrm{T}=200-450{ }^{\circ} \mathrm{C} \\
{[\mathrm{NO}]=0.1 \%,\left[\mathrm{C}_{3} \mathrm{H}_{6}\right]=0.1 \%,\left[\mathrm{O}_{2}\right]=5 \%} \\
\text { Na-loadings: } 0,1.6,2.6 \text { and } 4.2 \mathrm{wt} \%\end{array}$ & $\begin{array}{l}\checkmark \quad \text { Strong promotion by Na with an optimal loading of } \\
2.6 \mathrm{wt} \% \text { Na. Higher Na-loadings caused strong } \\
\text { inhibition (volcano behaviour; over-promotion). } \mathrm{NO}_{\mathrm{x}} \\
\text { conversion window is widened and moved to } \\
\text { lower temperatures. } \\
>\quad \Delta \mathrm{T}_{50(\mathrm{C} 3 \mathrm{H} 6)} \sim \Delta \mathrm{T}_{50(\mathrm{NOx})}=-65^{\circ} \mathrm{C} ; \Delta \mathrm{S}_{\mathrm{N} 2}=+40 \% \text { at } \mathrm{T}> \\
320^{\circ} \mathrm{C} \text { for } 2.6 \mathrm{wt} \% \text { Na loading }\end{array}$ & [47] \\
\hline $\begin{array}{l}\mathrm{NO}, \mathrm{C}_{3} \mathrm{H}_{6} \\
\mathrm{CO}, \mathrm{H}_{2} \mathrm{O} \\
\mathrm{CO}_{2}, \mathrm{O}_{2} \\
\text { excess }\end{array}$ & $\begin{array}{l}\text { Ir-black } \\
(\mathrm{CCP})\end{array}$ & $\mathrm{Na}$ & $\begin{array}{c}\mathrm{T}=150-450{ }^{\circ} \mathrm{C} \\
{[\mathrm{NO}]=300 \mathrm{ppm},\left[\mathrm{C}_{3} \mathrm{H}_{6}\right]=1800 \mathrm{ppm},} \\
{[\mathrm{CO}]=450 \mathrm{ppm},\left[\mathrm{O}_{2}\right]=8 \%,\left[\mathrm{H}_{2} \mathrm{O}\right]=10 \%,} \\
{\left[\mathrm{CO}_{2}\right]=10.7 \%} \\
\text { Na-loadings: } 0-10 \mathrm{wt} \%\end{array}$ & $\begin{array}{l}\checkmark \quad \text { Na-loadings }>\sim 1 \mathrm{wt} \% \text { enhanced the selectivity } \\
\text { towards } \mathrm{N}_{2} \text { in the whole temperature range }(150-450 \\
{ }^{\circ} \mathrm{C} \text { ) but not affected the activity. } \\
\checkmark \quad \mathrm{Na}^{\circ} \text { loadings }>3 \mathrm{wt} \% \text { caused rate inhibition for all CO, } \\
\mathrm{NO}_{\mathrm{x}}, \mathrm{C}_{3} \mathrm{H}_{6} \text { conversions. }\end{array}$ & [107] \\
\hline $\begin{array}{l}\mathrm{NO}, \mathrm{C}_{3} \mathrm{H}_{6} \\
\quad\left(\mathrm{O}_{2}\right)\end{array}$ & $\begin{array}{c}\text { Ir film on }(\mathrm{K}) \beta^{\prime \prime} \mathrm{Al}_{2} \mathrm{O}_{3} \text { solid electrolyte } \\
(\mathrm{EPOC})\end{array}$ & K & $\begin{array}{c}\mathrm{T}=250-400{ }^{\circ} \mathrm{C} \\
{[\mathrm{NO}]=0.2 \%,\left[\mathrm{C}_{3} \mathrm{H}_{6}\right]=0.2 \%} \\
{\left[\mathrm{O}_{2}\right]=0-5 \%} \\
\theta_{\mathrm{K}}=0-100 \%\end{array}$ & $\begin{array}{l}\text { Marginal effects of } \mathrm{K} \text { addition on the Ir surface at } \\
\text { reducing (absence of } \mathrm{O}_{2} \text { ) conditions. Strong } \\
\text { K-induced poisoning at oxidizing conditions for both } \\
\text { propene oxidation and } \mathrm{NO}_{x} \text { reduction with } \\
\text { significant decreases in } \mathrm{N}_{2} \text {-selectivity, as well. }\end{array}$ & [108] \\
\hline
\end{tabular}



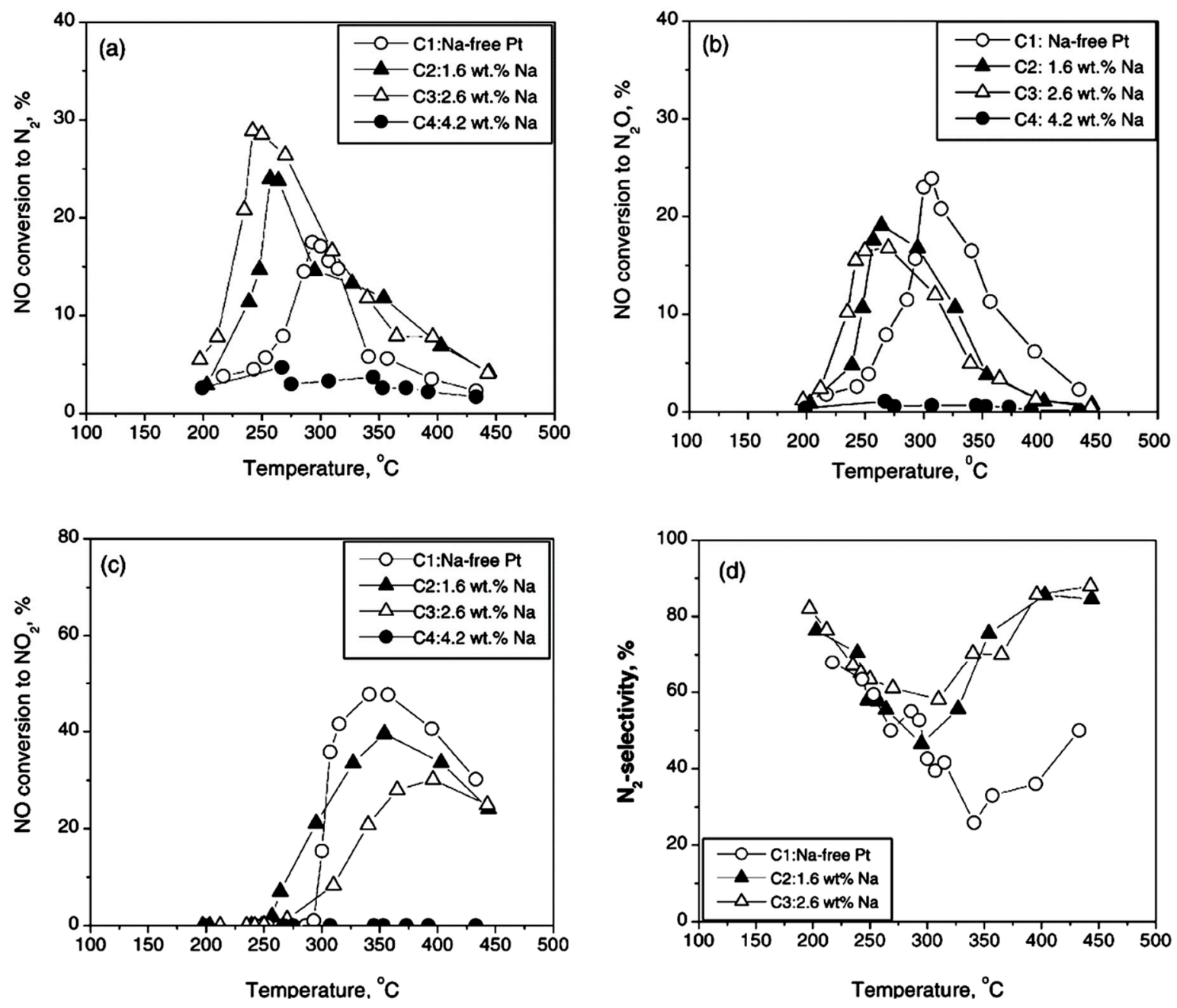

Figure 18. $\mathrm{C}_{3} \mathrm{H}_{6}+\mathrm{NO}+\mathrm{O}_{2}$ reaction on Na-promoted $\mathrm{Pt} / \gamma-\mathrm{Al}_{2} \mathrm{O}_{3}$ catalysts. The effect of temperature on the conversion of $\mathrm{NO}$ to various $\mathrm{N}$-containing products and the corresponding $\mathrm{N}_{2}$-selectivity: (a) $\mathrm{NO}$ conversion to $\mathrm{N}_{2} ;$ (b) $\mathrm{NO}$ conversion to $\mathrm{N}_{2} \mathrm{O}$; (c) $\mathrm{NO}$ conversion to $\mathrm{NO}_{2} ;$ (d) $\mathrm{N}_{2}$-selectivity. Conditions:

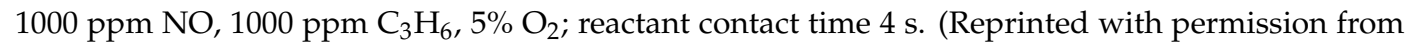
Ref. [47]; Copyright 2005, Elsevier).

The performance of another noble metal, iridium, the three-way catalytic chemistry of which has several promising characteristics, have been studied under Na-promotion by Wogerbauer et al. [107]. A simulated exhaust gas mixture consisted of 300 ppm NO, 0.18\% propene, 450 ppm CO, 8\% $\mathrm{O}_{2}, 10 \%$ $\mathrm{H}_{2} \mathrm{O}, 10.7 \% \mathrm{CO}_{2}$, balance $\mathrm{N}_{2}$ was used, while the temperature and Na promoter loading were varied between $150-450{ }^{\circ} \mathrm{C}$ and $0-10 \mathrm{wt} \%$, respectively. They found that under the conditions used and for $\mathrm{Na}$ loadings higher than $\sim 3 w t \%$, Na caused an inhibition on the Ir-black catalytic activity for CO, propene and $\mathrm{NO}_{x}$ conversions (Table 7). However, the selectivity towards $\mathrm{N}_{2}$ was significantly improved up to $100 \%$ for samples with $\mathrm{Na}$ contend $>\sim 1 \mathrm{w} \mathrm{t} \%$ in the whole temperature range.

More recently, Goula et al. studied the effect of electrochemically supplied potassium on a porous Ir-film catalyst under the $\mathrm{NO}+\mathrm{C}_{3} \mathrm{H}_{6}+\mathrm{O}_{2}$ reaction at a variety of oxygen concentrations [108]. In this EPOC study the Ir-film was interfaced with a $(\mathrm{K}) \beta^{\prime \prime} \mathrm{Al}_{2} \mathrm{O}_{3}$ solid electrolyte on which the catalyst was supported by spattering. It was found that $\mathrm{K}$ addition on the Ir surface is detrimental on catalyst performance (propene oxidation, $\mathrm{NO}$ reduction efficiency and $\mathrm{N}_{2}$-selectivity) for all oxygen concentrations investigated. Only at zero $\mathrm{O}_{2}$ concentration, that is ,, at net reducing conditions of the reactive mixture, a slight promoting effect of potassium on the $\mathrm{N}_{2}$-selectivity but not on the rates was observed (Table 7). This very different effect of alkali-promotion, compared to that observed on $\mathrm{Pt}$ 
and Pd noble metals under similar conditions (on which strong promotional effects were recorded), was understandable in terms of the electronic influence of co-adsorbed potassium on the adsorption strengths of the neighbour reactants on the Ir surface: the excessive enhancement of oxygen adsorption on Ir sites in the expense of the hydrocarbon adsorption caused O-poisoning of the surface.

Overviewing Section 3.2.2 and the involved literature listed in Table 7, it is apparent that as we have seen in Section 3.1.4, alkali-promotion of the reduction of NO by propene remains very effective even under excess $\mathrm{O}_{2}$ conditions, at concentrations $>\sim 5 \%$ which simulate lean-burn and diesel engines exhaust gases. However, at excess oxygen conditions promotional effects on both activity and selectivity are significantly attenuated and also limited in quite narrows temperature and/or promoter loading windows. Volcano type behaviour of promotion is once again recorded upon increasing alkali loading and EPOC or CCP promotion characteristics were qualitatively similar.

\subsection{Mechanistic Implications: The mode of Action of Electropositive Promoters}

\subsubsection{Main Promotion Characteristics and Mechanistic Implications}

The above described results show that electropositive promoters (alkalis and alkaline earths) can markedly affect the catalytic properties of Pt-group metals during $\mathrm{CO}$ or hydrocarbons oxidation and $\mathrm{NO}$ reduction by $\mathrm{CO}$ or hydrocarbons in the absence or presence of oxygen, as well as of other environmentally important reactions (see Tables 1-7). The promotional benefits on the catalytic performance (activity, selectivity) achieved were similar, independently of the promotion method used, that is , the electrochemical promotion of catalysis (EPOC) or the conventional catalyst promotion one (CCP). The intensity of promotion, the optimal promoter loading and other characteristics of the induced promotional effects are subjected to the specific reaction/catalyst system and the individual reaction conditions applied (Tables 1 and 2).

This electropositive promotion (by alkalis and alkaline earths) of PGMs for emissions control catalysis reaction was found to be very pronounced not only when applied to model reaction systems (Tables 1-5) but also under complex reaction systems that mirror practical applications, that is, stoichiometric gasoline, lean-burn and diesel engines exhaust conditions (Tables 6 and 7). The latter boosts the practical importance of the subject and direct implementations on practical systems appear attractive and promising.

Model reactions studies and their individual characteristics (Section 3.1) enabled us to better understand the mechanism of the promoters' action. EPOC has also a significant role on this issue, since it gave us the opportunity of in situ adjustment of the promoter loading, recording at the same time its influence on the catalytic performance. Recall that some studies were explicitly focussed on experimentally establishing that EPOC and CCP are similar in origin and are subjected to the same physicochemical rules; the only practical different is the procedure used for the ptomoter supply $[21,22,25]$. To this end, Yentekakis and co-workers [21,22] have first shown that the promotional effects of sodium, electrochemically induced (via EPOC) on the $\mathrm{NO}+\mathrm{C}_{3} \mathrm{H}_{6} / \mathrm{Pt}$ catalytic system, mirror those obtained on a highly dispersed $\mathrm{Pt} / \gamma-\mathrm{Al}_{2} \mathrm{O}_{3}$ catalyst, promoted by means of CCP method at similar conditions. Therefore, EPOC and CCP will be hereafter considered as identical phenomena; the mechanistic model described below that interprets the mode of action of electropositive promoters, may be considered identical valid for both promotion methods. The vast majority of the publications reviewed here have been based on this model to consistently interpret individual promotional phenomena appeared at the specific reaction systems investigated. The main body of the model is described below and several direct spectroscopic evidences supporting its consistency are presented.

Using EPOC (via a galvanic cell as it was described by the formula (1) and Figure 1) one can electrochemically control (Faraday law) the migration of promoting species (e.g., $\mathrm{Na}^{+}$, Figure 19) from the solid electrolyte onto the catalyst/gas interface, where an effective and overall neutral double layer is formed through this ions back-spill over imposed electrochemically (Figure 19). 
Actually, the electrocatalytic reaction taking place at the three-phase-boundary metal-solid electrolyte-gas that leads to the formation of the effective double layer is $[6,7,16,109]$ :

$$
\mathrm{Na}^{+}\left(\text {from } \beta^{\prime \prime} \mathrm{Al}_{2} \mathrm{O}_{3}\right)+\mathrm{e}^{-}(\text {from metal }) \rightarrow\left[\mathrm{Na}^{\delta+}-\delta^{-}\right](\text {on metal })
$$

where $\left[\mathrm{Na}^{\delta+}-\delta^{-}\right]$denotes the overall neutral Na species present at the metal-gas interface (effective double layer): the $\mathrm{Na}$ adatom on the metal surface carries a charge $\delta^{+}$and $\delta^{-}$is the image charge in the metal; the charge $\delta$ is about $0.8-0.5$, decreasing with increasing Na coverage [7].

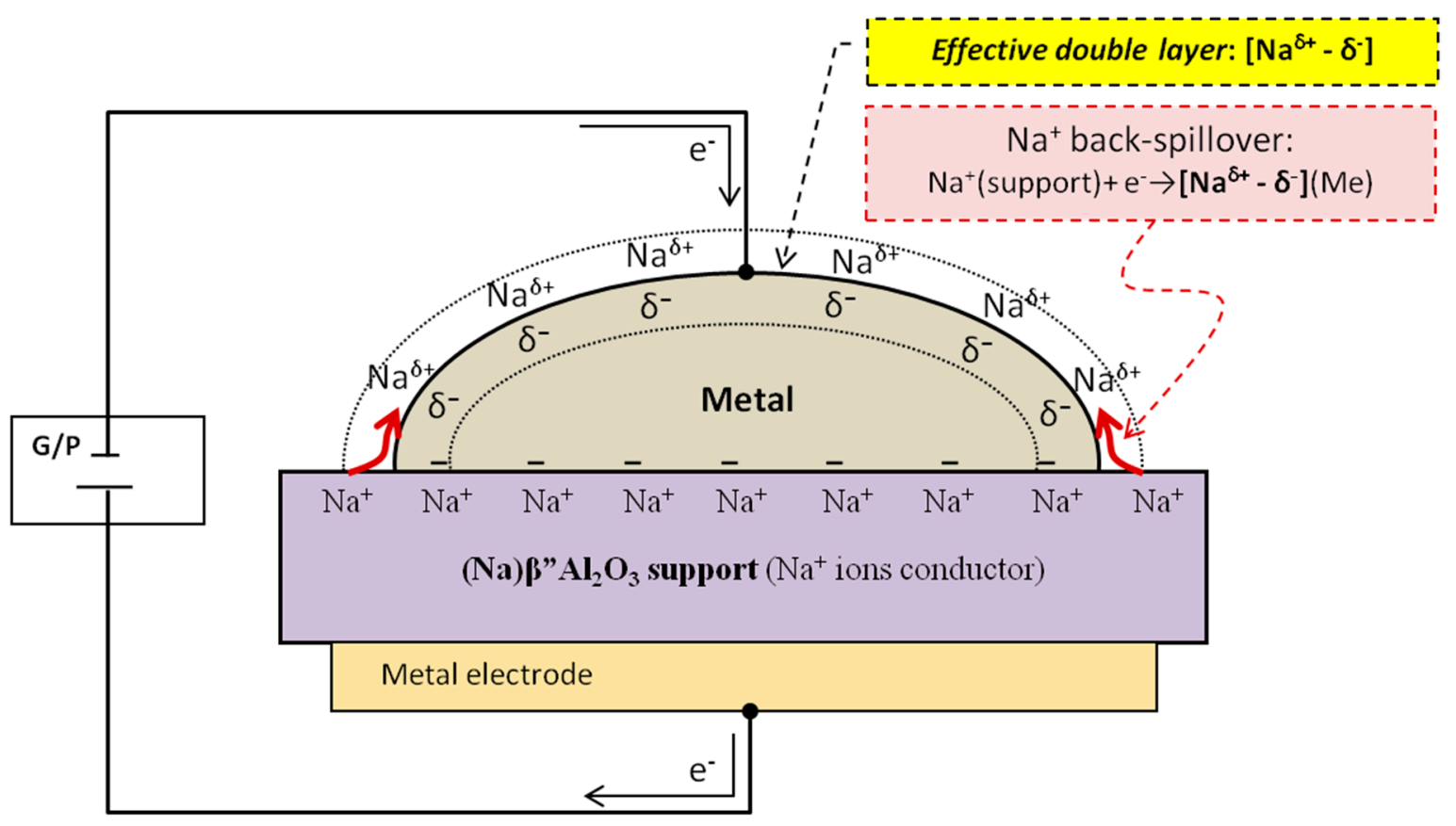

Figure 19. Schematic of the effective double layer approach of catalyst promotion $[6,7,110]$. An electron enriched (lower work function) catalyst surface is developed due to the uniformly dispersed $\mathrm{Na}^{\delta+}$ adatoms.

It is worth noting that an identical configuration is expected on the metal catalyst surface when $\mathrm{Na}$ is introduced to the catalyst by conventional methods (e.g., impregnation, vapor deposition, etc.), as recently demonstrated by Lambert and co-workers $[110,111]$ who showed using XPS that the electrochemically-supplied sodium is identical with gas-supplied (by evaporation) of $\mathrm{Na}^{\delta+}$ cations on the catalyst surface.

Since alkali ad-atoms are imposed on the catalyst surface, they are spread over the entire metal surface due to strong repulsive dipole-dipole interactions, establishing a homogeneous, neutral, effective double layer. This double layer corresponds to an electrically modified metal surface, practically an electron enriched (lower work function) metal surface due to the $\delta^{-}$charge located at the metal side interface half-layer. This electrically modified surface interacts with the co-adsorbed reactants, reaction intermediates and products, changing their binding energies (in respect to those on a promoter-free metal surface), producing pronounced alterations in catalytic performance. Therefore, the main feature of the electropositive promotion of PGM by alkalis and alkaline earths is the resulted electron enriched, lower work function, PGM surface.

Therefore, the concomitant alterations on the adsorption characteristics of the co-adsorbed reactants on such a modified metal surface are of course subjected to the electronic properties of the reactants: electrophilic (electron acceptor) or electrophobic (electron donor): both theory [112] and experiment (e.g., [106,113]) have shown that electropositively promoted (by alkalis) Pt-group metal (PGM) surfaces appear strengthening in the bonds of the metal—electron acceptor (electrophilic) 
adsorbates, for example, PGM-NO, PGM-O 2 , PGM-N, PGM-O, PGM-CO and weakening in the bonds of the metal-electron donor (electrophobic) adsorbates, for example, PGM-hydrocarbons and their fragments, PGM-CO. Donation and/or backdonation issues of electron charge between adsorbates and metal surfaces during the formation of a chemisorptive bond and their impact on the bond strength have been thoroughly explained by Vayenas and Brosda in Ref. [114] and in brief summarized in the following statements: "Electron backdonation to bonding singly occupied orbitals of an electron acceptor reactant lying below the metal Fermi level $\left(E_{F}\right)$ results in strengthening of the metal-adsorbate bond, while electron backdonation to antibonding orbitals, leads to weakening of the chemisorptive bond and destabilization of the adsorbate. Also electron donation to a metal from a singly occupied orbital on an electron donor adsorbate lying above Fermi level of the metal leads in general to strengthening of the chemisorptive bond. There are cases, such as the CO chemisorption on transition metals, where both donation of electrons (from the adsorbate to the metal) and backdonation of electronic charge (from the metal to the adsorbate) play an important role in the chemisorptive bond formation (e.g., Blyholder model for CO chemisorption [115])"; (The latter explains why someone can find $\mathrm{CO}$ to be considered as an electron-acceptor or even as an electron-donor adsorbate). These modifications on the reactants chemisorptive bonds are accompanied by alterations in the activation energies of the catalytic reactions and in some cases on their mechanism (e.g., on the rate determination step), resulted to dramatic changes on their intrinsic activity and/or selectivity. The specific features of the promotion are subjected to the specific catalytic systems under consideration and to the reaction conditions imposed.

Taking into account that the vast majority of the reactions involved in emission control catalysis processes obey Langmuir-Hinshelwood mechanism (competitive adsorption of the reactants), the following example could be of usefulness for a better understanding of the mechanism of action of the promoters under the concept of the effective double layer approach. Let's suggest a starting rate at point 1 on the rate versus [A] curve I (Figure 20), as determined by the applied reaction conditions on the unpromoted reaction $\mathrm{A}+\mathrm{B}$, that are considered to follow a typical Langmuir-Hinshelwood (LH) mechanism with the well-known characteristic rate maximum (point 2) due to the competitive adsorption of the reactants. The reaction rate is proportional to the product of the reactants' coverages, $\theta_{\mathrm{A}} \cdot \theta_{\mathrm{B}}$ (Equation (10)), maximized at equilibrated coverages $\theta_{\mathrm{A}}$ and $\theta_{\mathrm{B}}$ on the catalyst surface:

$$
\mathrm{r}=\mathrm{k}_{\mathrm{o}} \exp \left(-\mathrm{E}_{\mathrm{a}} / \mathrm{RT}\right) \theta_{\mathrm{A}} \cdot \theta_{\mathrm{B}}
$$

where $k_{o} \exp \left(-E_{a} / R T\right)=k$ is the temperature dependence of the rate constant $k$ with a pre-exponential factor $k_{\mathrm{o}}$ and an apparent activation energy $\mathrm{E}_{\mathrm{a}}$.

Applying (chemically or electrochemically) a promoter, the created effective double layer (Figure 19) causes alterations on the adsorption strengths of the reactants, modifying their coverages $\theta_{\mathrm{A}}$ and $\theta_{\mathrm{B}}$ thus giving the possibility of their adjustment at the equilibrated values $\theta_{\mathrm{A}}{ }^{*}$ and $\theta_{\mathrm{B}}{ }^{*}$ that minimizes reaction probability and consequently rate (point 2):

$$
\mathrm{r}^{*}=\mathrm{k}_{\mathrm{o}} \exp \left(-\mathrm{E}_{\mathrm{a}} / \mathrm{RT}\right) \theta_{\mathrm{A}}^{*} \cdot \theta_{\mathrm{B}}^{*}
$$

However, this is the minimum effect that can be offered by this course and actually Equation (11) and consequently path $1 \rightarrow 2$ are not real: Due to the induced changes on the chemisorptive bonds of the reactant, alteration on the apparent activation energy of the reaction is also expected from the unpromoted value $\mathrm{E}_{\mathrm{a}}$ to a modified value $\mathrm{E}_{\mathrm{a}}{ }^{*}$, leading the reaction rate to follow a new substantially enhanced behaviour (curve II, Figure 20, for example, point 3), following Equation (12):

$$
\mathrm{r}^{* *}=\mathrm{k}_{\mathrm{o}} \exp \left(-\mathrm{E}_{\mathrm{a}}^{*} / \mathrm{RT}\right) \theta_{\mathrm{A}} * \theta_{\mathrm{B}}{ }^{*}
$$

Notably, in the cases where reaction mechanism modifications are induced by the promoter as well (e.g., change of the rate determination step), promotion can receive unprecedented enhancements (promoted rate ${ }^{* * *}$ on curve III, Figure 20, e.g., point 4). 


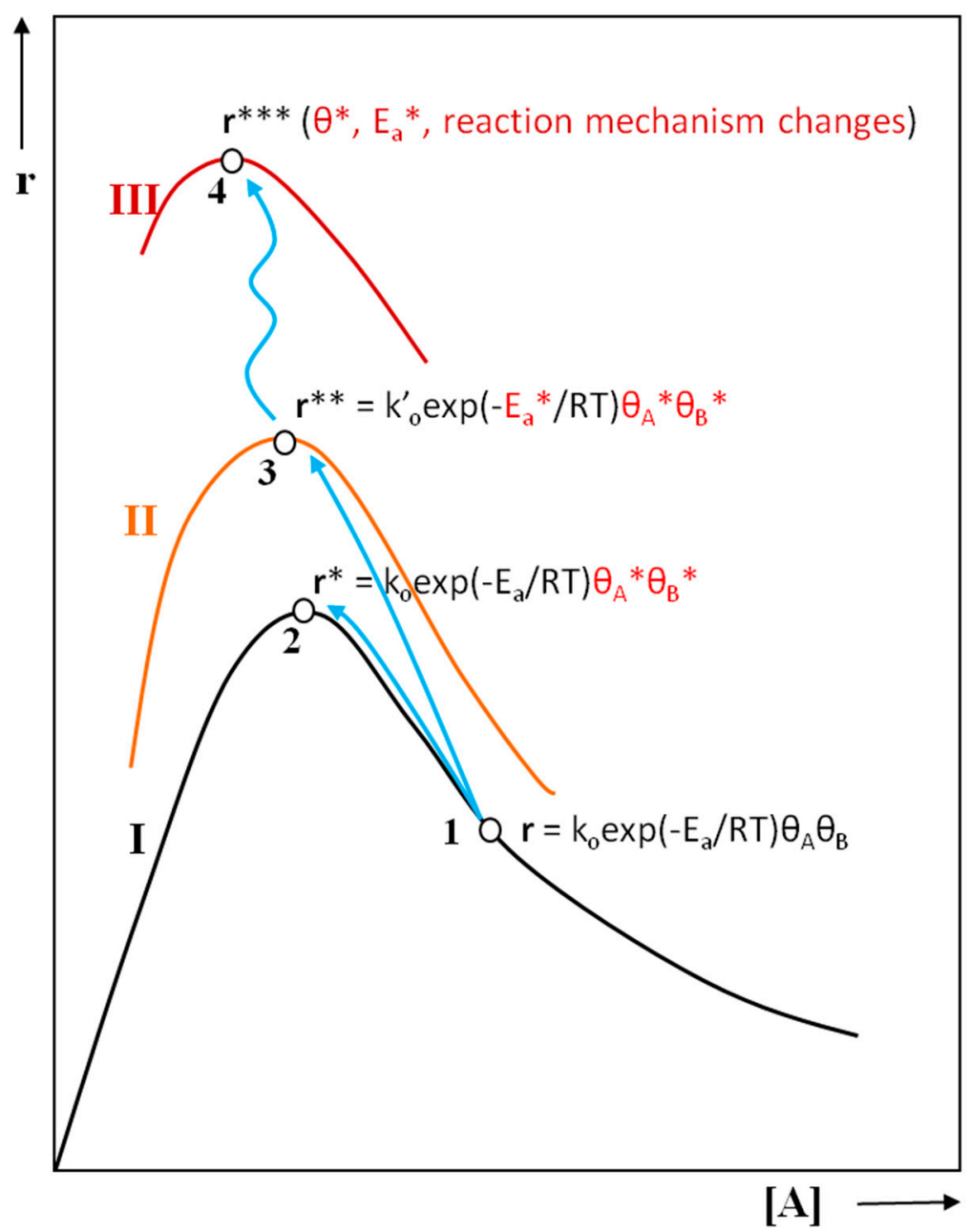

Figure 20. Schematic representation of the mechanism of promotion on a Langmuir-Hinshelwood type reaction.

An example which mirrors all the aforementioned issues is the alkali-promoted $\mathrm{NO}+\mathrm{C}_{3} \mathrm{H}_{6}$ reaction on $\mathrm{Pt}[15,58,61]$; reaction rate enhancements up to $40,000 \%$ were achieved accompanied with dramatic chances on the selectivity towards $\mathrm{N}_{2}$, as well (Table 4). The promotion mechanism on this system is described as follow (Figure 21):

First, it is well established that $\mathrm{NO}+\mathrm{C}_{3} \mathrm{H}_{6}$ reaction over Pt obeys Langmuir-Hinshelwood type kinetics with characteristic rate maxima reflecting competitive adsorption of the two $\mathrm{NO}$ and $\mathrm{C}_{3} \mathrm{H}_{6}$ reactants on $\mathrm{Pt}$ active sites; these rate maxima occurred at very low $\mathrm{C}_{3} \mathrm{H}_{6} / \mathrm{NO}$ ratios $(<0.08)$, that is, very high $\mathrm{NO}$ concentrations relative to $\mathrm{C}_{3} \mathrm{H}_{6}$ are necessary in order to achieve a comparable coverage of both reactants on the Pt surface, thus maximizing the rate [58,62], reflecting a weaker adsorption of $\mathrm{NO}$ on $\mathrm{Pt}$ sites relative to $\mathrm{C}_{3} \mathrm{H}_{6}[58,62,67,68]$ mainly due to the presence of $\pi$-electrons in the alkene structure. As a consequence, in a wide range of reactants partial pressures and temperatures conditions the un-promoted (alkali-free) Pt surface is predominantly covered by propene and propene-derived fragments (Figure 21a), therefore the un-promoted reaction rate, $\mathrm{r}_{\mathrm{o}}$, is quite low.

Addition of alkali, which is accompanied by the formation of the [Alkali $\left.{ }^{\delta+}-\delta^{-}\right]$effective double layer, provides an electron enriched (lower work function) metal surface that in effect favours the adsorption of electrophilic co-adsorbates (NO) and inhibit that of electrophobic co-adsorbates $\left(\mathrm{C}_{3} \mathrm{H}_{6}\right.$ and its fragments). According to the following Reaction (13)-(18) scheme,

$$
\mathrm{NO}(\mathrm{g}) \rightarrow \mathrm{NO}_{\text {ads }} \quad \text { (enhanced by alkali addition) }
$$




$$
\begin{aligned}
& \mathrm{NO}_{\mathrm{ads}} \rightarrow \mathrm{N}_{\mathrm{ads}}+\mathrm{O}_{\mathrm{ads}} \quad \text { (enhanced by alkali addition) } \\
& \mathrm{C}_{3} \mathrm{H}_{6}(\mathrm{~g}) \rightarrow \mathrm{C}_{3} \mathrm{H}_{6, \text { ads }} \quad \text { (inhibited by alkali addition) } \\
& \mathrm{N}_{\mathrm{ads}}+\mathrm{N}_{\mathrm{ads}} \rightarrow \mathrm{N}_{2}(\mathrm{~g}) \\
& \mathrm{N}_{\mathrm{ads}}+\mathrm{NO}_{\mathrm{ads}} \rightarrow \mathrm{N}_{2} \mathrm{O}(\mathrm{g}) \\
& \mathrm{O}_{\text {ads }}+\text { hydrocarbonaceous species (or } \mathrm{CO} \text { ) } \rightarrow \mathrm{CO}_{2}(\mathrm{~g})+\mathrm{H}_{2} \mathrm{O}(\mathrm{g} \text { ) }
\end{aligned}
$$

the resulted effects are (Figure 21b): (i) strengthening of the Pt-NO bond with a concomitant enhancement population of NO molecules on the alkali-modified surface (Reaction (13)) -the surface populations of $\mathrm{NO}$ and propene are therefore equilibrated; (ii) strong enhancement of the dissociative adsorption of $\mathrm{NO}$ (Reaction (14)) as a result of the Pt-NO bonds strengthening and the concomitant weakening of the $\mathrm{N}-\mathrm{O}$ bond in the adsorbed $\mathrm{NO}$ molecules - the surface is enriched with very active atomic oxygen species; (iii) weakening of the strength of the $\mathrm{Pt}-\mathrm{C}_{3} \mathrm{H}_{6}$ bond-an equilibrated population of more active (due to their weaker adsorption) hydrocarbonaceous species is resulted (Reaction (15), Figure 21b).

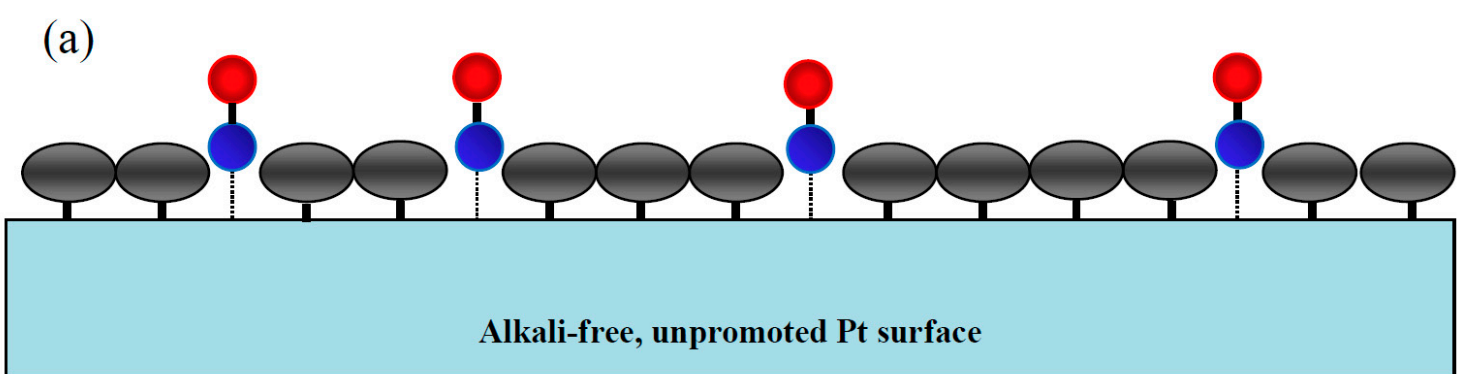

Main features:
(i) Pronounced strong adsorption of propene
(ii) Weak and limited adsorption of NO
(iii) Low reaction probability

(b)

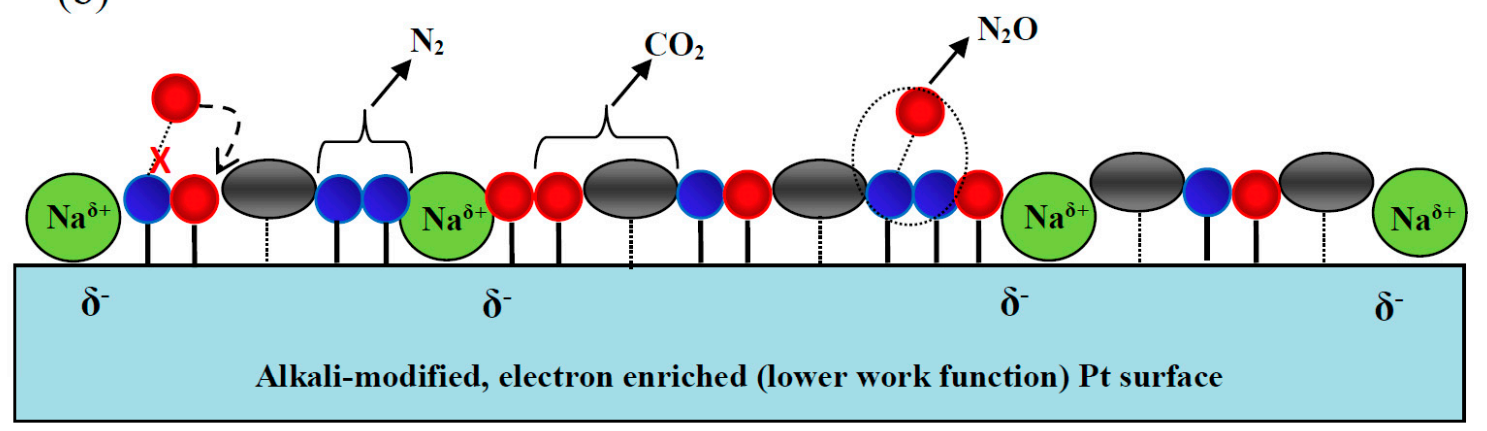

Main features:

(i) Enhanced NO adsorption in expense of that of propene

(ii) Weakening of the $\mathrm{N}-\mathrm{O}$ bond resulting to an enhanced NO dissociation

(iii) Changes in the reaction apparent activation energy

(iv) Equilibrated coverages of the reactants, high reaction probability

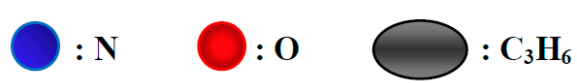

Figure 21. Schematic of the mechanism of action of alkalis as promoters on the Pt-catalysed $\mathrm{NO}+\mathrm{C}_{3} \mathrm{H}_{6}$ reaction. Expected distribution of reactants and/or intermediates over the unpromoted surface (a) and the Na-promoted surface $(\mathbf{b})$. 
All these factors operate together in increasing the reaction probability of $\mathrm{NO}$ and propene molecules, leading to an enhanced promoted rate, $r_{p}$, over the alkali-modified surface. These changes on adsorbed species distribution and/or population (coverage), their bond-strengths and activation energies and on reaction rate-determination-step (rds) were successfully used to convincingly interpret the rate enhancement values, $\rho=\mathrm{r}_{\mathrm{CCP}} / \mathrm{r}_{\mathrm{O}}$, as high as 420 and 280 for $\mathrm{N}_{2}$ and $\mathrm{CO}_{2}$ productions have been reported for this catalytic system under electropositive promotion by alkalis or alkaline earths $[15,61,62]$. Notably, these gains in catalytic activity did not reflect the maxima of the L-H rate curves, that is, were not restricted by the optimal balance of the competitive reactants' coverages. These were extraordinarily larger, due to the synergy of the aforementioned factors.

The observed increase in $\mathrm{N}_{2}$-selectivity upon electropositive promotion can be also readily understood in terms of the above considerations. According to the reaction network (13)-(18), the production rates of $\mathrm{N}_{2}$ and $\mathrm{N}_{2} \mathrm{O}$ depend on the extent of $\mathrm{NO}$ dissociation (reaction (14)), which is followed by the elementary Reactions (16) and (17). The observed increase in the $\mathrm{N}_{2}$-selectivity upon promoter addition is a consequence of increased NO dissociation, that is, less molecular NO and more atomic $\mathrm{N}$ on the surface. According to Lang et al. [112], the electrostatic field produced by $\mathrm{Na}^{+}$can shift the $\pi *$-orbital energy of $\mathrm{NO}$ adsorbed in the vicinity of an alkali ion below the Pt Fermi level. Then, valence electrons from the metal can populate the $\mathrm{NO} \pi *$-orbital energy, resulting in weakening of the $\mathrm{N}-\mathrm{O}$ bond and a strengthening of the $\mathrm{Pt}-\mathrm{N}$ bond. Both factors favour Reaction (16) over Reaction (17), leading to higher $\mathrm{N}_{2}$ selectivity.

In the case of $\mathrm{CO}+\mathrm{O}_{2}$ reaction the strong promotion observed under $\mathrm{CO}$-rich reaction conditions (e.g., $[16,27])$, was understandable by means of the pronounced strengthening of the $\mathrm{O}$ adsorption bond, compared to that of $\mathrm{CO}$ : at such conditions where $\mathrm{CO}$ coverage predominates and the formation of $\mathrm{CO}$ islands suppresses reaction probability, the alkali-induced pronounced adsorption of $\mathrm{O}$ species causes destruction of $\mathrm{CO}$ islands thus increasing reaction probability [16].

In the case of alkanes oxidation, it is well known that alkanes, in particular $\mathrm{CH}_{4}$, have low propensity for adsorption (activation) on PGM surfaces. The adsorption of these electrophobic adsorbates is being even worse on alkali-modified electron enriched surfaces. This makes the generally observed alkali-induced poisoning of alkanes oxidation reactions readily understandable, no matter of what oxidant agent (oxygen or NO) used $[48,49,65,66]$.

The opposite was true for alkenes oxidation (by $\mathrm{O}_{2}$ or $\mathrm{NO}$ ), due to their strong propensity to adsorb on PGMs. Thus, weakening their adsorption and at the same time strengthening the adsorption of the electrophilic limiting reactant $(\mathrm{O})$ on the alkali modified PGM surfaces are factors that operate synergistically creating ideal promotion conditions (e.g., [18,20,43-47]).

Comparing the alkali promotion of the NO reduction by alkenes, the $\mathrm{Ir} \sim \mathrm{Rh}<\mathrm{Pd}<\mathrm{Pt}$ increasing order can be observed: marginal promoting effects have been obtained during $\mathrm{Rh}$ - or Ir-catalysed NO reduction by propene $[59,60,64,107,108]$, in opposite to the very large on $\mathrm{Pd}[14]$ and to the extraordinarily large on $\mathrm{Pt}$ (e.g., $[15,58,61,62,106])$ This is related to the different propensity of NO adsorption on these metals: on Ir and Rh, NO has high propensity of adsorption, which is also dissociative; on Pd less and partly dissociative, while on $\mathrm{Pt}$ it is even less and non-dissociative. Therefore, enhancing NO adsorption by alkali-promotion on Ir and Rh surfaces has not further practical value (NO adsorption/dissociation is close to ideal on the unpromoted Ir and Rh), while on $\mathrm{Pt}$ the non-dissociative and quite limited NO adsorption can become much stronger and fully dissociative, enabling Pt to behave like Rh or Ir (e.g., [15,47,61,62,89]).

Comparing the amount of an alkali necessary to optimize promotion for a certain reaction on different Pt group metals, the general trend is that only few surface concentrations are needed in the case of Rh and $\operatorname{Ir}\left(\mathrm{ca} . \theta_{\text {Alkali }} \sim 1-3 \%\right)$, quite more for Pd $\left(\theta_{\text {Alkali }} \sim 5-10 \%\right)$ and much more for Pt $\left(\theta_{\text {Alkali }} \sim 15-40 \%\right)$ (e.g., $\left.[14,15,18,22,51,57,58,108]\right)$. This is readily understandable in similar terms used above: Rh and Ir electron availability (work function, WF) is by its own close to the optimal value for the reactions under consideration and only few amounts of alkalis are necessary for the optimal 
promoter loading adjustment. The opposite is true for $\mathrm{Pd}$ and in particular for $\mathrm{Pt}$; these two metals showing a higher WF than Rh and Ir.

For a certain catalytic system and operating conditions, the amount of alkali that is needed to optimize promotion depends on the chemical identity of the alkali: heavier alkalis appear to be more effective that the lighter ones (e.g., [61]). This is fully consistent to the effective double layer approach considered and to the theoretical predictions of Lang et al. [112], which have shown that the larger the alkali cation the greater the effect its electric field has on an electron acceptor adsorbate (e.g., NO).

In the cases of more complex reactions systems, as for instance those simulating automotive exhaust gas mixtures, the explanation of the promotional effects is typically more complicated and may involve all the possible effects, synergistic or competitive, induced through the modification of the metal work function on all electrophilic and/or electrophobic reactant species and intermediates on such a densely populated surface with all these competitive species (e.g., $[47,79,89,106])$.

It is also of worth noting that: (i) Alkalis and alkaline earths are typically permanent promoters as a result of the fact that they do not participate in the reactions networks. This is of high technological importance: since the optimal alkali amount is incorporated on the catalyst and independently of the method used for its supply (EPOC or CCP), its amount remains practically constant for a very long time offering promotion. This explains why Faradaic Efficiency values as large as $\Lambda>10^{5}$ have been measured in EPOC by alkalis studies (e.g., [16-18,42]). (ii) Volcano type behaviour of the promotional effects as a function of the promoter loading was an additional common feature of the titled promotion, that is, outgoing of the optimal amount of the promoter (the so-called over-promotion) the reaction is gradually inhibited rather than promoted (e.g., [15-17,47,58]). Two main factors were considered to be responsible for this behaviour: (a) the extended strengthening of the adsorption bond of the electrophilic adsorbate (electronic effect) and (b) the formation of extended surface complexes of the promoter with the reactant species and/or reaction intermediates that can block active sites (geometric effect). These factors can operate together suppressing the rate in case of over-promoted catalysts. However, it must be noticed that the formation of such 2D or 3D surface alkali complex compounds (alkali nitrites, nitrates, carbonates, oxides or even superoxides, depending on the reaction atmosphere), that can be valid even at low promoter loadings, do not actually cancel the role of alkali as a promoter (e.g., $[20,43-46,51,52,57-60])$. On the opposite, stabilization on the catalysts surfaces, even at elevated temperatures of catalytic interest, of normally volatile alkali metals is achieved by the formation of such stable surface alkali complex compounds.

\subsubsection{Direct Spectroscopic and Other Analytical Technique Evidences}

Besides of the numerous kinetic studies demonstrating the usefulness of the electropositive promotion of PGM in emissions control catalysis, particular emphasis to direct evidences for the origin and mechanism of this promotion have been devoted by several research groups using a variety of surface science or other analytical techniques, including: in situ diffuse reflectance infrared Fourier transform spectroscopy (DRIFTS) [95-98,113], x-ray photoelectron spectroscopy (XPS) (e.g., [51,52,111]), temperature programmed desorption (TPD) [106,116-120], scanning tunnelling microscopy (STM) [121-123] and work function [51,52] measurements.

To this end, Koukiou et al. [113], studying the interaction of NO with Na-modified Pt surfaces over a conventional, highly dispersed, $\mathrm{Pt}$ catalyst, namely $\mathrm{Pt}(\mathrm{Na}) / \gamma-\mathrm{Al}_{2} \mathrm{O}_{3}$, by means of in situ DRIFTS, have shown that increasing sodium loading causes a pronounced and progressive red shift of the $\mathrm{N}-\mathrm{O}$ stretching frequency (Figure 19) associated with molecular NO adsorbed on the Pt component of the supported catalyst.

At the highest sodium loading ( $10 \mathrm{wt} \% \mathrm{Na}$; corresponding to an upper limit of about $\theta_{\mathrm{Na}}=0.5$ nominal sodium fractional coverage on Pt particles [102]) a $1680 \mathrm{~cm}^{-1}$ species is observed that corresponds to an activated $\mathrm{NO}^{\delta-}$ species with bond order 2, that is, a negatively charged adsorbate with increased electron density in the $\pi^{*}$ antibonding orbital. The rigorous model developed by Lang et al. [112] was considered for understanding the effect of alkali on Pt surface. They have shown 
that the inhomogeneous electric field associated with adsorbed alkali ions acts to depress the energy of the antibonding $\pi^{*}$ orbital of electron-accepting (electrophilic) co-adsopbates (e.g., CO, NO) bellow the metal Fermi level. Therefore, the red shifts showed in Figure 22, as authors argue [113], are due to the resulting metal $\rightarrow$ adsorbate charge transfer that acts to weaken the $\mathrm{N}-\mathrm{O}$ bond, red-shifting its vibration frequency and promoting its dissociation, rather than to alkali-induced changes in the relative populations of various forms of adsorbed NO.

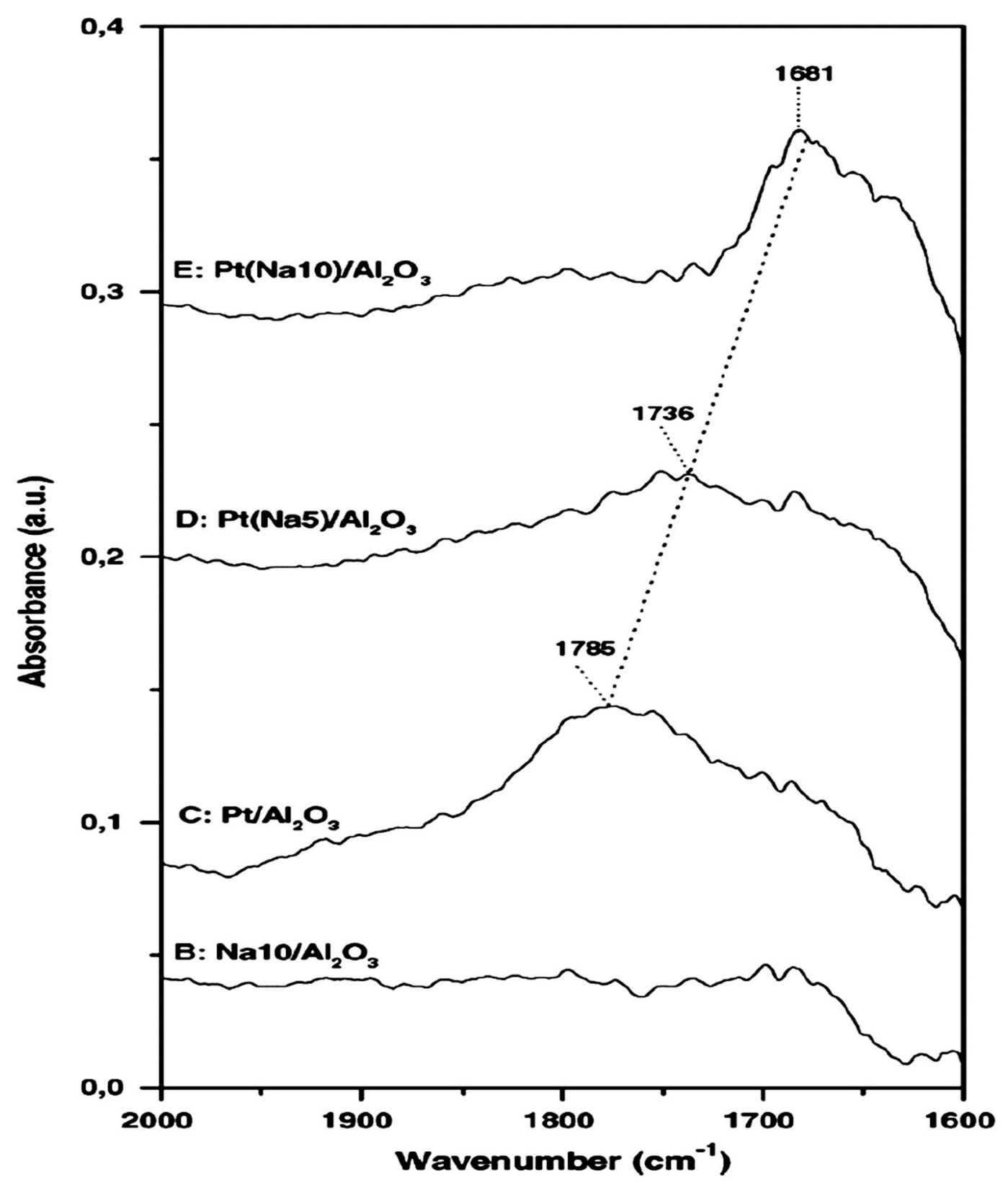

Figure 22. DRIFT spectra (expanded scale for the region $2000-1600 \mathrm{~cm}^{-1}$ and subtracting spectrum of pure $\mathrm{Al}_{2} \mathrm{O}_{3}$ ) obtained with $10 \mathrm{wt} \% \mathrm{Na} / \gamma-\mathrm{Al}_{2} \mathrm{O}_{3}(\mathbf{B}), \mathrm{Pt} / \gamma-\mathrm{Al}_{2} \mathrm{O}_{3}(\mathbf{C}), \mathrm{Pt}(\mathrm{Na} 5) / \gamma-\mathrm{Al}_{2} \mathrm{O}_{3}$ (D) and $\mathrm{Pt}(\mathrm{Na10}) / \gamma-\mathrm{Al}_{2} \mathrm{O}_{3}$ (E) samples after $\mathrm{NO}$ adsorption for $1 \mathrm{~min}$ at $27^{\circ} \mathrm{C}$. (Reprinted with permission from Ref. [113]; Copyright 2007, Elsevier).

The chemisorption characteristics of $\mathrm{NO}$ on Na-dosed $\mathrm{Pt}\{111\}$ surface has been also studied by Harkness and Lambert [116] by means of temperature-programmed desorption (TPD). It was clearly demonstrated that the presence of $\mathrm{Na}$ on the $\mathrm{Pt}\{111\}$ single crystal causes an increase in the adsorption energy of $\mathrm{NO}$ (i.e., strengthening of the metal-NO bond) accompanied by a monotonically increased 
NO dissociation (i.e., $\mathrm{N}_{2}$ desorption) as a function of Na coverage. In particular, NO-TPD spectra on Na-dosed Pt $\{111\}$ (from 0 to 1.2ML of Na coverage) have showed two characteristic peaks, indicated as features (a) and (b); sodium caused an increase in the desorption peak (a) temperature from $360 \mathrm{~K}$ on the clean $\mathrm{Pt}\{111\}$ to $380 \mathrm{~K}$ at $0.25 \mathrm{ML}$ Na-dosed Pt $\{111\}$. Even at very low Na coverages (>0.1 ML), the second NO desorption feature (b) from sodium affected sites is appeared at $\sim 520 \mathrm{~K}$ which is grew at the expense of the feature (a) and progressively shifted to higher desorption temperature, up to $610 \mathrm{~K}$, upon increasing Na coverage to 1.2 ML. At the same time, the feature (a) is progressively attenuated to zero (practically vanished at $>1 \mathrm{ML}$ of $\mathrm{Na}$ ); A progressively increased $\mathrm{N}_{2}$ peak is concomitant to the aforementioned TPD experiment, with the $\mathrm{N}_{2}$ desorption peak to remain constant at $540 \mathrm{~K}$ up to $1 \mathrm{ML}$ of $\mathrm{Na}$, after which it is shifted to $540 \mathrm{~K}$ for $1.2 \mathrm{ML}$ (i.e., $100 \%$ dissociation of adsorbed $\mathrm{NO}$ can be obtained at sufficiently high, ca $1 \mathrm{ML}$, sodium coverage) [116].

Similar TPD studies by Garfungel et al. [117], involving the interaction of NO with K-dosed Pt $\{111\}$, yielded the same evidences: an alkali-induced increase in the Pt-NO bond strength accompanied by alkali-promoted NO dissociation was demonstrated.

Temperature-programmed desorption (TPD) studies after adsorption of oxygen on Na-dosed $\mathrm{Pt} / \mathrm{Al}_{2} \mathrm{O}_{3}$ catalysts where performed by Vernoux et al. [106] in order to elucidate possible influences of the $\mathrm{Na}$ addition on the $\mathrm{Pt}-\mathrm{O}$ bond strength. They demonstrated that the adsorption strength of the atomic oxygen (an electron acceptor adsorbate) on the Pt component of the catalyst is enhanced by $\mathrm{Na}$ addition; their data clearly showed that the temperature of the oxygen desorption peak correspond to $\mathrm{Pt}-\mathrm{O}$ interaction increases with increasing $\mathrm{Na}$ loading of the catalyst, directly evidencing a strengthening of the $\mathrm{Pt}-\mathrm{O}$ bond [106].

A number of early and recent studies concern the chemisorption of $\mathrm{CO}$ on alkali-modified PGM surfaces [95-97,117-120]. To this end, Bertolini et al. [118] studied the chemisorption of CO on K-modified Pt(100) surfaces by means TPD and Auger Electron Spectroscopy (AES). The progressive increase on the $\mathrm{CO}$ desorption peak temperature (i.e., strengthening of the $\mathrm{Pt}-\mathrm{CO}$ ) as a function of $\mathrm{K}$ coverage, observed at low $\mathrm{K}$ coverages $\theta_{\mathrm{K}}$ (ca. 0-0.4), was attributed to long range uniform electronic modifications, that is, work function changes, due to charge transfer; $K^{\delta+}(\delta \approx 1)$ adspecies appear on the K-dosed surface, uniformly distributed due to repulsion between these charged species. Such an electron enriched (lower work function) Pt surface strengthens the adsorption of $\mathrm{CO}$ via substantial charge donation form the K-modified Pt surface into the $2 \pi^{*}$ orbitals of CO [118]. At high K coverages (ca. 0.45-1) short range interactions between the $\mathrm{CO}$ and $\mathrm{K}$ adspecies, that is, an even more direct bonding of $\mathrm{CO}$ with $\mathrm{K}$ (formation of CO-K-Pt surface complexes), were considered.

Pitchon et al. studied the effect of $\left(\mathrm{Li}, \mathrm{Na}, \mathrm{K}\right.$ and $\mathrm{Cs}$ )-dosed $\mathrm{Pd} / \mathrm{SiO}_{2}$ on $\mathrm{CO}$ adsorption characteristics [119]. They demonstrated drastic changes in the infrared spectrum of $\mathrm{CO}$ adsorbed on $\mathrm{Pd}$ sites; a significant weakening on the strength of the $\mathrm{C}-\mathrm{O}$ bond of adsorbed $\mathrm{CO}$ molecules caused the appearance of a new $v \mathrm{CO}$ band at low infrared frequency-the extent of the interaction was depended by the nature of the alkali. These influences were assigned to a localized interaction "Pd-CO-alkali" rather than to long range electronic modifications.

Using FTIR spectroscopy, Liotta et al. studied the effect of sodium on the adsorption of CO on Pd-based catalysts supported on two different supports $\left(\mathrm{SiO}_{2}\right.$ and model or natural pumices) [120]. Depending on the support used, the appearance of both electronic and geometric effects-that attributed to the different localization of sodium ions in the catalysts- were evidenced; the geometric effects were predominant in the $\mathrm{Pd} / \mathrm{SiO}_{2}$ catalysts, whereas electronic effects were most important than the geometric ones in the $\mathrm{Pd} /$ pumise catalysts. It was again considered in this study that an electronic density transfer to Pd is the common effect of the presence of alkali either it is subsequently added to the catalysts or is present as a structural component of the support, although, the authors observed important geometric effects in the former case. The electronic effect, that produces a red shift (towards lower frequencies) of the $\mathrm{CO}$ bands of the IR spectra of chemisorbed $\mathrm{CO}$, owing to an enhanced transfer of electron density from the metal to the $\pi^{*}$ molecular orbitals of $\mathrm{CO}$, was again invoked [120]. 
Electron enriched Pt surfaces resulted by combined application of alkali-induced surface promotion and support-mediated promotion by Ce-based mixed oxides were also recently demonstrated via in situ DRIFTS studies by Yentekakis and co-workers [95-97]. Over doubly promoted $\mathrm{Pt}(\mathrm{Na}) / \mathrm{Al}_{2} \mathrm{O}_{3}-\mathrm{CeO}_{2}-\mathrm{La}_{2} \mathrm{O}_{3}$ catalysts operated under TWC conditions, the authors demonstrated a substantial population of adsorbed species at $2060 \mathrm{~cm}^{-1}$ attributed to $\mathrm{CO}$ on reduced $\mathrm{Pt}^{0}$ sites when $\mathrm{CeO}_{2}-\mathrm{La}_{2} \mathrm{O}_{3}$ was incorporated into the $\mathrm{Al}_{2} \mathrm{O}_{3}$ support. This feature was substantially exacerbated when Na promoter was also incorporated in the catalyst formulation, while at the same time the formation of active Pt-NCO intermediates at about $2180 \mathrm{~cm}^{-1}$, which resulted from an enhanced NO decomposition, was facilitated by alkali-promotion on the $\mathrm{Pt}(\mathrm{Na}) / \mathrm{Al}_{2} \mathrm{O}_{3}-\mathrm{CeLa}$ catalyst (Figure 21). On the un-modified $\mathrm{Pt} / \mathrm{Al}_{2} \mathrm{O}_{3}$ catalyst counterpart, $\mathrm{CO}$ species adsorbed on positively charged $\mathrm{Pt}$ sites $\left(\mathrm{Pt}^{\delta+}-\mathrm{CO}\right)$ were assigned (Figure 23). These features, fully compatible with the way of action of alkali promotion analysed so far, were considered as a convincing explanation of the substantially enhanced TWC performance of this complex reactions/catalyst system.

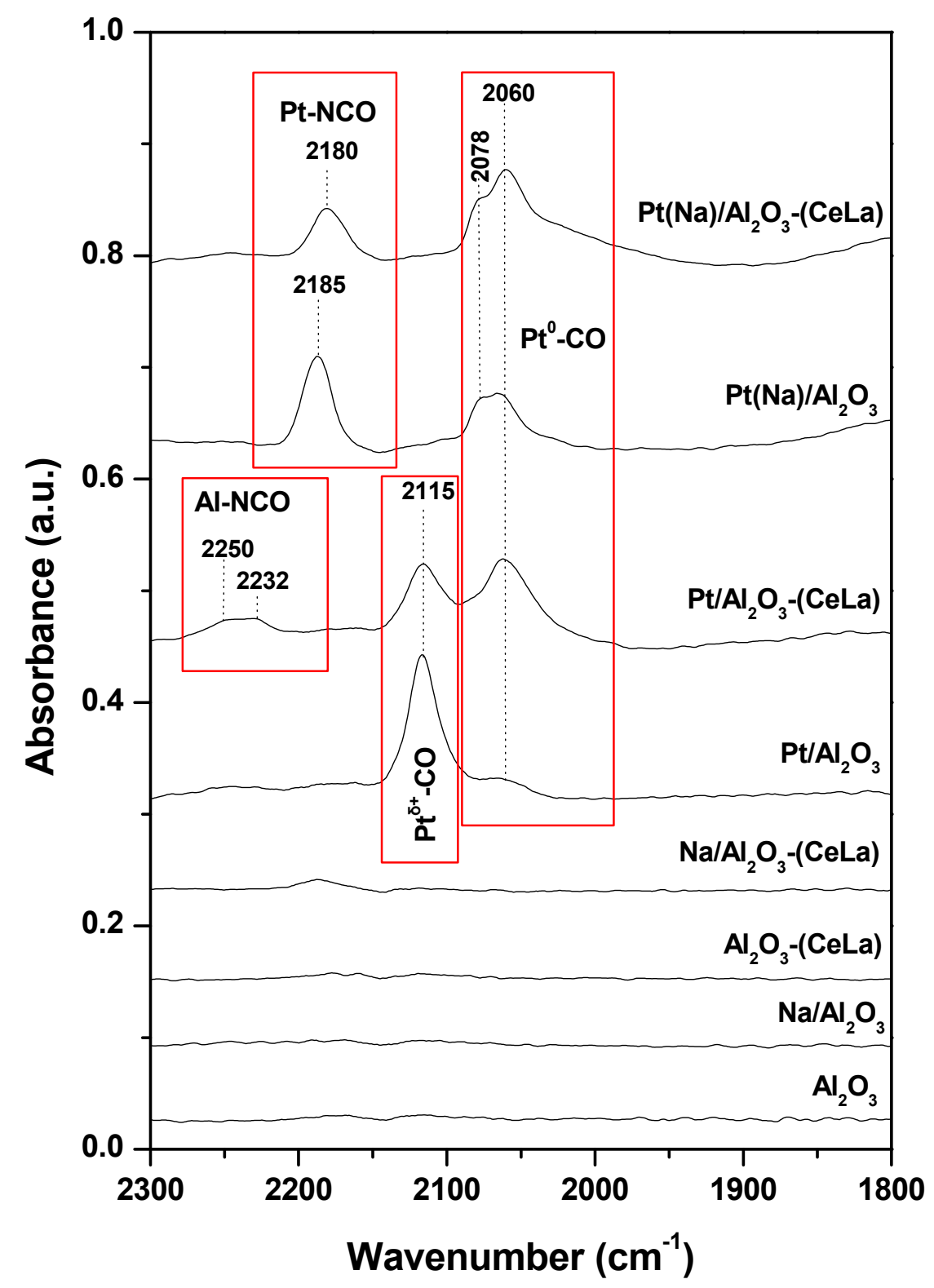

Figure 23. In-situ DRIFT spectra during simulated TWC reaction conditions (1000 ppm NO + $1067 \mathrm{ppm}$ $\mathrm{C}_{3} \mathrm{H}_{6}+7000 \mathrm{ppm} \mathrm{CO}+7800 \mathrm{ppm} \mathrm{O}_{2} ; \mathrm{F}_{\mathrm{t}}=80 \mathrm{~cm}^{3} / \mathrm{min} ; \mathrm{T}=200{ }^{\circ} \mathrm{C}$ ). (Reproduced with permission from Ref. [96]. Copyright 2008, Elsevier). 
Finally, a number of studies involving x-ray photoelectron spectroscopy (XPS) published by the groups of Lambert and Yentekakis (e.g., [20,51,52,57-60]) have doubtlessly shown that in EPOC studies that concern PGMs films interfaced with an alkali conducting solid electrolyte, the promoting species are indeed alkaline ions reversibly supplied by the external bias onto the catalyst surface.

The authors have also shown that under reaction conditions the electrochemically supplied alkali ions form stable surface compounds (e.g., alkali nitrites, nitrates and carbonates) that can act as promoters even under such formulations and which, in excess (over-promotion), induce geometric, active sites blocking, phenomena and thus poisoning effects on PGMs activity [20,51,52,57-60]. Combining XPS and ultraviolet photoelectron spectroscopy (UPS), the authors demonstrated a linear relationship of the catalyst work function $(\Delta \Phi)$ and the alkali coverage $\left(\theta_{\mathrm{Na}}\right)$ with the catalyst potential overpotential $\left(\Delta \mathrm{V}_{\mathrm{WR}}\right)$ (Figure 24) [51,52] and confirmed that electrochemically supplied alkali ions on the catalyst surface are identical in behaviour (and chemical state) with the alkali supplied by vacuum deposition [21,22]. This makes the close similarities found between EPOC and CCP methodologies of catalyst promotion readily understandable $[15,21,22,25,58]$ and prompts for the use of EPOC as an effective and rapid method for exploring the effects of a range of promoters and for assessing the response of the reaction rate/selectivity to promoter coverage (finding out its optimal loadings at any set of conditions) before applying them to the design of efficient conventional catalyst formulations.
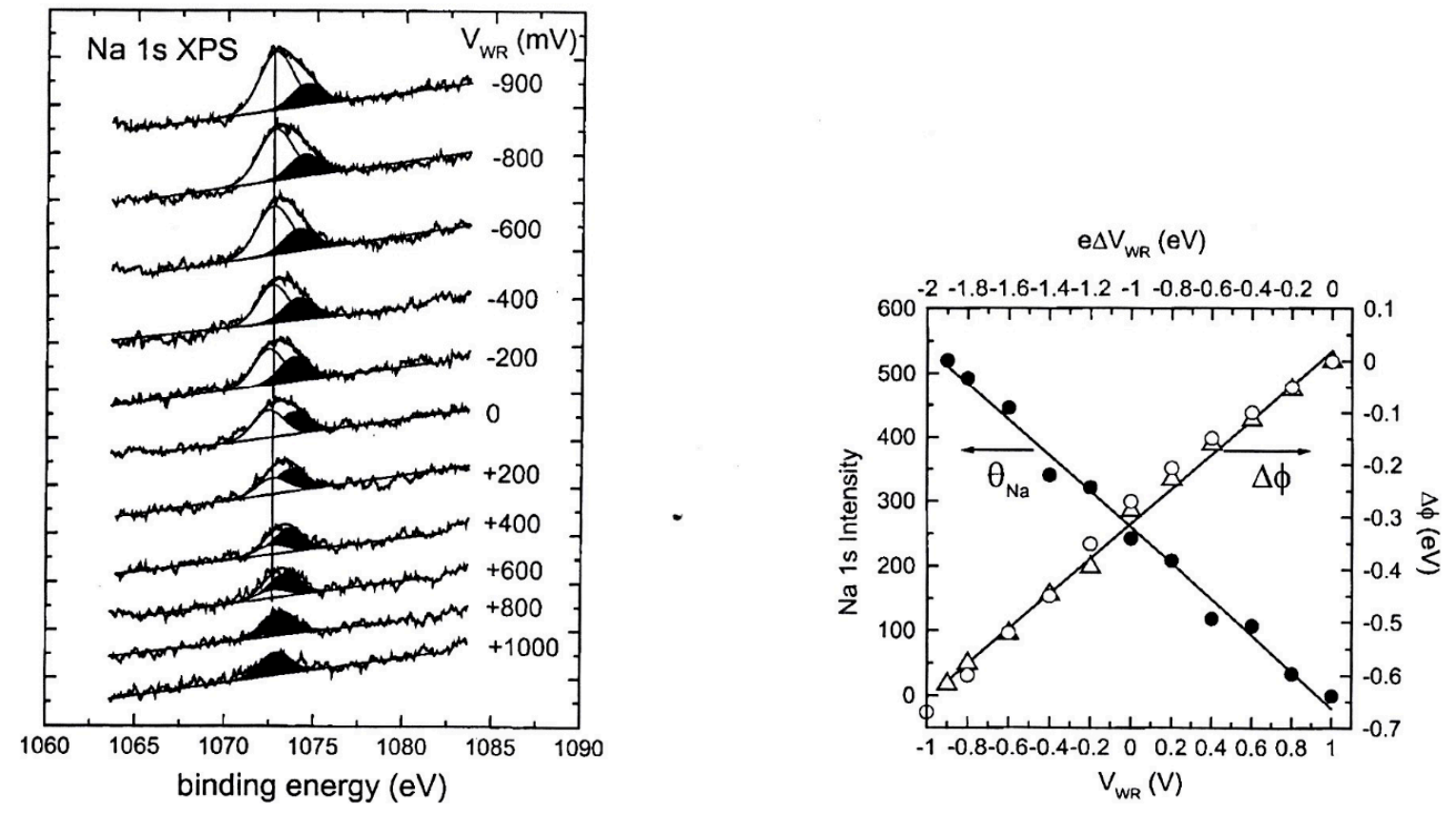

Figure 24. Na 1s XPS spectra versus catalyst potential $\left(\mathrm{V}_{\mathrm{WR}}\right)$ for $\mathrm{Rh}$ film interfaced with $(\mathrm{Na}) \beta^{\prime \prime} \mathrm{Al}_{2} \mathrm{O}_{3}$ $\mathrm{Na}^{+}$-ions conductor, at $307^{\circ} \mathrm{C}$ and UHV conditions. The inset shows the integrated Na1s XPS intensity due to sodium on the Rh surface and associated work function change of the Rh film as a function of $\mathrm{V}_{\text {WR }}$. Data was acquired using a $\mathrm{Rh} /(\mathrm{Na}) \beta^{\prime \prime} \mathrm{Al}_{2} \mathrm{O}_{3} / \mathrm{Au}$ galvanic cell (Reproduced with permission from Ref. [51]. Copyright 2001, American Chemical Society).

A recent review of the literature using surface analysis techniques to shed light on the electropositive promotion via the EPOC concept has recently provided by Gonzalez-Cobos and de Lucas-Consuegra [124].

All the aforementioned in this chapter studies, unambiguously lead to the main conclusion that alkalis adatoms on PGM surfaces provide electron enriched metal sites (lower work function surfaces), which favour the adsorption of electron donor (electrophilic) co-adsorbates and inhibit the adsorption of electron acceptor (electrophobic) co-adsorbates. The formation of alkali-reactants-metal surface complexes and therefore geometric type influences, besides the above electronic ones, can be at work 
in cases where the conditions assist such a course. These issues were considered in the vast majority of electropositive promotion studies by alkalis or alkaline earths to explain promotion phenomena observed on PGM-catalysed emissions control catalysis reactions.

\section{Conclusions and Perspectives}

The electropositive promotion, by alkalis or alkaline earths, has been found to be an effective tool for promoting the catalytic performance of Platinum Group Metals for the vast majority of important reactions involved in emissions control catalysis systems, such as $\mathrm{CO}$ and alkenes oxidations, $\mathrm{NO}$ reduction by $\mathrm{CO}$, alkenes or $\mathrm{H}_{2}, \mathrm{~N}_{2} \mathrm{O}$ decomposition and/or reduction; the only exceptions were the alkanes oxidation by dioxygen or NO.

Up to two orders of magnitude rate increases were achievable, in particular with electropositive-promoted $\mathrm{Pt}$, while in de-Nox reactions the selectivity towards $\mathrm{N}_{2}$ was simultaneously improved towards values approaching $100 \%$ over the "optimally promoted" catalysts.

Promotional achievements were large not only for model reactions but also for gas mixtures that simulate practical systems, such as stoichiometric gasoline, lean-burn or diesel engines exhaust streams.

The intensity of promotion was generally followed the order $\mathrm{Pt}>\mathrm{Pd}>\mathrm{Rh} \sim \mathrm{Ir}$, thus providing $\mathrm{Pt}$ or Pd-based catalysts to operate like Rh or even better in emissions control catalytic reactions. These achievements were lead to the synthesis of novel simple in synthesis and cost-effective monometallic (Pt or Pd-only) with low precious metal loading, extremely active, stable and readily recycling, three-way catalyst formulations that were compared well with commercial bi- or three-metallic $(\mathrm{Rh}, \mathrm{Pt}$, Pd)-TWCs for the control of stoichiometric gasoline engines exhaust emissions. The absence of rare and expensive $\mathrm{Rh}$ in the formulations of three-way converters has therefore been introduced with the concomitant environmental and economic gains.

Electropositive promotion of PGM was also found to be effective at excess oxygen conditions (e.g., lean-burn of diesel engines exhaust gases), without however in that case to obtain solutions fully satisfying the requirements.

Latterly, doubly promoted catalyst formulations, combing electropositive promotion by alkalis and support-mediated promotion by mixed oxide supports (including combinations of $\mathrm{Al}_{2} \mathrm{O}_{3}$ with $\mathrm{CeO}_{2}, \mathrm{ZrO}_{2}, \mathrm{La}_{2} \mathrm{O}_{3}$ or $\mathrm{TiO}_{2}$ ) have been found to provide even better promotion and stability for emissions control implementations. Such synergistic promotion catalysts' designs could lead to control systems readily adapted on a number of specific emissions of stationary sources, that have high environmental footprint and their control is an urgent issue.

From the theoretical point of view, electropositive promotion of PGM was successfully understood and interpreted in terms of the effective double layer approach, that is, a homogeneous, neutral, effective double layer established by the alkali (or alkaline earths) adatoms that are spread over the entire PGM surface providing an electron enriched (lower work function) metal surface due to the $\delta^{-}$charge located at the metal side interface half-layer, which interacts with the co-adsorbed reactants, reaction intermediates and products, changing their binding energies producing pronounced alterations in catalytic performance. To this end, strengthening in the bonds of the metal-electron acceptor adsorbates and weakening in the bonds of the metal—electron donor adsorbates are resulted, which are accompanied by alterations in the activation energies of the reactions between them, leading to dramatic changes of the intrinsic catalytic performance (activity and/or selectivity). In particular, in emissions control catalysis processes involving $\mathrm{NO}_{\mathrm{x}}$ reduction, the promotion of the dissociative chemisorption of the NO molecules, which is a key reaction initiating step in deNO $\mathrm{x}_{\mathrm{x}}$ processes, facilitated by the alkali-induced strengthening of the PGM-NO and the accompanied weakening of the $\mathrm{N}-\mathrm{O}$ bond of the adsorbed $\mathrm{NO}$ molecules, convincingly interpret the enormous effective promotion of both deNO $\mathrm{N}_{x}$ activity and $\mathrm{N}_{2}$-selectivity offered via electropositive promotion of these catalytic systems.

Author Contributions: I.V.Y. was the primary author, writing this review and contributing to the conception, design and comparative interpretation of the literature. P.V., A.C. and G.G. provided assistance in writing, discussing and interpreting results and updating the article. All authors have a significant research contribution 
in the field, publishing a number of papers that are included and analysed in the present review. All authors read and approved the final version of the manuscript.

Acknowledgments: I.V.Y. and G.G. acknowledge support of the European Union and Greek national funds through the Operational Program "Competitiveness, Entrepreneurship and Innovation," under the call "RESEARCH-CREATE-INNOVATE" (project code: T1EAK-00782). The authors thank all co-workers, colleagues and researchers contributed in the field. This work is dedicated to Professor Costas G. Vayenas, to whom the authors express their gratitude for discovering and introducing to science the EPOC phenomenon (described also as "the NEMCA effect"), which obviously is of high fundamental and practical importance and has opened new horizons in the frontiers of Catalysis and Electrochemistry.

Conflicts of Interest: The authors declare no conflict of interest.

\section{References}

1. Kaspar, J.; Fornasiero, P.; Hickey, N. Automotive catalytic converters: Current status and some perspectives. Catal. Today 2003, 77, 419-449. [CrossRef]

2. Farrauto, R.J.; Heck, R.M. Catalytic converters: State of the art and perspectives. Catal. Today 1999, 51, 351-360. [CrossRef]

3. Yentekakis, I.V.; Konsolakis, M. Three-way Catalysis (Book Chapter). In Perovskites and Related Mixed Oxides: Concepts and Applications; Wiley-VCH, Vergal GmbH \& Co. KGaA: Weinheim, Germany, 2016; pp. 559-586. Available online: https://onlinelibrary.wiley.com/doi/pdf/10.1002/9783527686605.ch25 (accessed on 12 November 2015).

4. Wuebbles, D.J. Nitrous Oxide: No Laughing Matter. Science 2009, 326, 56-57. [CrossRef] [PubMed]

5. Ravishankara, A.R.; Daniel, J.S.; Portmann, R.W. Nitrous Oxide ( $\left.\mathrm{N}_{2} \mathrm{O}\right)$ : The Dominant Ozone-Depleting Substance Emitted in the 21st Century. Science 2009, 326, 123-125. [CrossRef] [PubMed]

6. Vayenas, C.G.; Bebelis, S.; Yentekakis, I.V.; Lintz, H.-G. Non-faradaic electrochemical modification of catalytic activity: A status report. Catal. Today 1992, 11, 303-442. [CrossRef]

7. Vayenas, C.G.; Bebelis, S.; Pliangos, C.; Brosda, S.; Tsiplakides, D. Electrochemical Activation of Catalysis; Kluwer Academic/Plenum: New York, NY, USA, 2001.

8. Stoukides, M.; Vayenas, C.G. The effect of electrochemical oxygen pumping on the rate and selectivity of ethylene oxidation on polycrystalline silver. J. Catal. 1981, 70, 137-146. [CrossRef]

9. Yentekakis, I.V.; Vayenas, C.G. The effect of electrochemical oxygen pumping on the steady-state and oscillatory behaviour of CO oxidation on polycrystalline Pt. J. Catal. 1988, 111, 170-188. [CrossRef]

10. Vayenas, C.G.; Bebelis, S.; Neophytides, S. Non-faradaic electrochemical modification of catalytic activity. J. Phys. Chem. 1988, 92, 5083-5085. [CrossRef]

11. Vayenas, C.G.; Bebelis, S.; Ladas, S. Dependence of catalytic rates on catalyst work function. Nature 1990, 343, 625-627. Available online: https:/ / www.nature.com/articles/343625a0 (accessed on 15 February 1990). [CrossRef]

12. Yentekakis, I.V.; Bebelis, S. Study of the NEMCA effect in a single-pellet catalytic reactor. J. Catal. 1992, 137, 278-283. [CrossRef]

13. Vernoux, P.; Lizarraga, L.; Tsampas, M.N.; Sapountzi, F.M.; De Lucas-Consuegra, A.; Valverde, J.-L.; Souentie, S.; Vayenas, C.G.; Tsiplakides, D.; Balomenou, S.; et al. Ionically Conducting Ceramics as Active Catalyst Supports. Chem. Rev. 2013, 113, 8192-8260. [CrossRef] [PubMed]

14. Yentekakis, I.V.; Lambert, R.M.; Tikhov, M.; Konsolakis, M.; Kiousis, V. Promotion by sodium in emission control catalysis: A kinetic and spectroscopic study of the Pd-catalysed reduction of NO by propene. J. Catal. 1998, 176, 82-92. [CrossRef]

15. Yentekakis, I.V.; Konsolakis, M.; Lambert, R.M.; Macleod, N.; Nalbantian, L. Extraordinarily effective promotion by sodium in emission control catalysis: $\mathrm{NO}$ reduction by propene over Na-promoted $\mathrm{Pt} / \gamma-\mathrm{Al}_{2} \mathrm{O}_{3}$. Appl. Catal. B 1999, 22, 123-133. [CrossRef]

16. Yentekakis, I.V.; Moggridge, G.; Vayenas, C.G.; Lambert, R.M. In situ controlled promotion of catalyst surfaces via NEMCA: The effect of Na on the Pt-catalysed CO oxidation. J. Catal. 1994, 146, 292-305. [CrossRef]

17. Palermo, A.; Lambert, R.M.; Harkness, I.R.; Yentekakis, I.V.; Marina, O.A.; Vayenas, C.G. Electrochemical promotion by $\mathrm{Na}$ of the platinum-catalysed reaction between CO and NO. J. Catal. 1996, 161, 471-479. [CrossRef] 
18. Harkness, I.R.; Hardacre, C.; Lambert, R.M.; Yentekakis, I.V.; Vayenas, C.G. Ethylene oxidation over platinum: In situ electrochemically controlled promotion using $\mathrm{Na}-\beta^{\prime \prime}$ alumina and studies with a $\mathrm{Pt}(111) / \mathrm{Na}$ model catalyst. J. Catal. 1996, 160, 19-26. [CrossRef]

19. Marina, O.A.; Yentekakis, I.V.; Vayenas, C.G.; Palermo, A.; Lambert, R.M. In situ controlled promotion of catalyst surfaces via NEMCA: The effect of Na on the Pt-catalysed NO reduction by $\mathrm{H}_{2}$. J. Catal. 1997, 166, 218-228. [CrossRef]

20. Filkin, N.C.; Tikhov, M.S.; Palermo, A.; Lambert, R.M. A kinetic and spectroscopic study of the in situ electrochemical promotion by sodium of the platinum-catalysed combustion of propene. J. Phys. Chem. A 1999, 103, 2680-2687. [CrossRef]

21. Konsolakis, M.; Palermo, A.; Tikhov, M.S.; Lambert, R.M.; Yentekakis, I.V. Electrochemical vs. Conventional promotion: A new tool to design effective, highly dispersed conventional catalysts. Ionics 1998, 4, 148-156. [CrossRef]

22. Yentekakis, I.V.; Konsolakis, M.; Lambert, R.M.; Palermo, A.; Tikhov, M. Successful application of electrochemical promotion to the design of effective conventional catalyst formulations. Solid State Ionics 2000, 136/137, 783-790. [CrossRef]

23. Nicole, J.; Tsiplakides, D.; Pliangos, C.; Verykios, X.E.; Comninelis, C.; Vayenas, C.G. Electrochemical promotion and metal-support interactions. J. Catal. 2001, 204, 23-34. [CrossRef]

24. Brosda, S.; Vayenas, C.G.; Wei, J. Rules of chemical promotion. Appl. Catal. B 2006, 68, 109-124. [CrossRef]

25. Pekridis, G.; Kaklidis, N.; Konsolakis, M.; Athanasiou, C.; Yentekakis, I.V.; Marnellos, G.E. A comparison between electrochemical and conventional catalyst promotion: The case of $\mathrm{N}_{2} \mathrm{O}$ reduction by alkanes or alkenes over K-modified Pd catalysts. Solid State Ionics 2011, 192, 653-658. [CrossRef]

26. Pliangos, C.; Yentekakis, I.V.; Verykios, X.E.; Vayenas, C.G. Non-Faradaic electrochemical modification of catalytic activity: VIII. Rh-catalysed $\mathrm{C}_{2} \mathrm{H}_{4}$ oxidation. J. Catal. 1995, 154, 124-136. [CrossRef]

27. De Lucas-Consuegra, A.; Dorado, F.; Valverde, J.L.; Karoum, R.; Vernoux, P. Electrochemical activation of Pt catalyst by potassium for low temperature CO deep oxidation. Catal. Commun. 2008, 9, 17-20. [CrossRef]

28. Mirkelamoglu, B.; Karakas, G. CO oxidation over palladium- and sodium-promoted tin dioxide: Catalyst characterization and temperature-programmed studies. Appl. Catal. A 2005, 281, 275-284. [CrossRef]

29. Mirkelamoglu, B.; Karakas, G. The role of alkali-metal promotion on CO oxidation over $\mathrm{PdO} / \mathrm{SnO}_{2}$ catalysts. Appl. Catal. A 2006, 299, 84-94. [CrossRef]

30. Lee, C.-H.; Chen, Y.-W. Effect of basic additives on $\mathrm{Pt} / \mathrm{Al}_{2} \mathrm{O}_{3}$ for $\mathrm{CO}$ and propylene oxidation under oxygen-deficient conditions. Ind. Eng. Chem. Res. 1997, 36, 1498-1506. [CrossRef]

31. Tanikawa, K.; Egawa, C. Effect of barium addition on CO oxidation activity of palladium catalysts. Appl. Catal A 2011, 403, 12-17. [CrossRef]

32. Minemura, Y.; Kuriyama, M.; Ito, S.; Tomishige, K.; Kunimori, K. Additive effect of alkali metal ions on preferential CO oxidation over Pt/ $\mathrm{Al}_{2} \mathrm{O}_{3}$. Catal. Commun. 2006, 7, 623-626. [CrossRef]

33. Minemura, Y.; Ito, S.; Miyao, T.; Naito, S.; Tomishige, K.; Kunimori, K. Preferential CO oxidation promoted by the presence of $\mathrm{H}_{2}$ over $\mathrm{K}-\mathrm{Pt} / \mathrm{Al}_{2} \mathrm{O}_{3}$. Chem. Commun. 2005, 11, 1429-1431. [CrossRef] [PubMed]

34. Tanaka, H.; Kuriyama, M.; Ishida, Y.; Ito, S.; Tomishige, K.; Kunimori, K. Preferential CO oxidation in hydrogen-rich stream over Pt catalysts modified with alkali metals: Part I. Catalytic performance. Appl. Catal. A 2008, 343, 117-124. [CrossRef]

35. Kuriyama, M.; Tanaka, H.; Ito, S.; Kubota, T.; Miyao, T.; Naito, S.; Timoshige, K.; Kunimori, K. Promoting mechanism of potassium in preferential $\mathrm{CO}$ oxidation on $\mathrm{Pt} / \mathrm{Al}_{2} \mathrm{O}_{3}$. J. Catal. 2007, 252, 39-48. [CrossRef]

36. Tanaka, H.; Kuriyama, M.; Ishida, Y.; Ito, S.; Kubota, T.; Miyao, T.; Naito, S.; Tomishige, K.; Kunimori, K. Preferential CO oxidation in hydrogen-rich stream over Pt catalysts modified with alkali metals: Part II. Catalyst characterization and role of alkali metals. Appl. Catal. A 2008, 343, 125-133. [CrossRef]

37. Pedrero, C.; Waku, T.; Iglesia, E. Oxidation of $\mathrm{CO}$ in $\mathrm{H}_{2}-\mathrm{CO}$ mixtures catalysed by platinum: Alkali effects on rates and selectivity. J. Catal. 2005, 233, 242-255. [CrossRef]

38. Kwak, C.; Park, T.-J.; Suh, D.J. Effects of sodium addition on the performance of $\mathrm{PtCo} / \mathrm{Al}_{2} \mathrm{O}_{3}$ catalysts for preferential oxidation of carbon monoxide from hydrogen-rich fuels. Appl. Catal. A 2005, 278, 181-186. [CrossRef]

39. Cho, S.-H.; Park, J.-S.; Choi, S.-H.; Kim, S.-H. Effect of magnesium on preferential oxidation of carbon monoxide on platinum catalyst in hydrogen-rich stream. J. Power Sources 2006, 156, 260-266. [CrossRef] 
40. De Lucas-Consuegra, A.; Princivalle, A.; Caravaca, A.; Dorado, F.; Guizard, C.; Valverde, J.L.; Vernoux, P. Preferential CO oxidation in hydrogen-rich stream over an electrochemically promoted Pt catalyst. Appl. Catal. B 2010, 94, 281-287. [CrossRef]

41. Liu, K.; Wang, A.; Zhang, T. Recent advances in preferential oxidation of CO reaction over platinum group metal catalysts. ACS Catal. 2012, 2, 1165-1178. [CrossRef]

42. Vayenas, C.G.; Bebelis, S.; Despotopoulou, M. Non-faradaic electrochemical modification of catalytic activity 4. The use of $\beta^{\prime \prime}-\mathrm{Al}_{2} \mathrm{O}_{3}$ as the solid electrolyte. J. Catal. 1991, 128, 415-435. [CrossRef]

43. Vernoux, P.; Gaillard, F.; Lopez, C.; Siebert, E. In-situ electrochemical control of the catalytic activity of platinum for the propene oxidation. Solid State Ionics 2004, 175, 609-613. [CrossRef]

44. Billard, A.; Vernoux, P. Electrochemical catalysts for hydrocarbon combustion. Top. Catal. 2007, 44, 369-377. [CrossRef]

45. De Lucas-Consuegra, A.; Dorado, F.; Valverde, J.L.; Karoum, R.; Vernoux, P. Low-temperature propene combustion over $\mathrm{Pt} / \mathrm{K}-\beta \mathrm{Al}_{2} \mathrm{O}_{3}$ electrochemical catalyst: Characterization, catalytic activity measurements and investigation of the NEMCA effect. J. Catal. 2007, 251, 474-484. [CrossRef]

46. De Lucas-Consuegra, A.; Dorado, F.; Jimenez-Borja, C.; Caravaca, A.; Vernoux, P.; Valverde, J.L. Use of potassium conductors in the electrochemical promotion of environmental catalysis. Catal. Today 2009, 146, 293-298. [CrossRef]

47. Yentekakis, I.V.; Tellou, V.; Bontzolaki, G.; Rapakousios, I.A. A comparative study of the $\mathrm{C}_{3} \mathrm{H}_{6}+\mathrm{NO}+\mathrm{O}_{2}$, $\mathrm{C}_{3} \mathrm{H}_{6}+\mathrm{O}_{2}$ and $\mathrm{NO}+\mathrm{O}_{2}$ reactions in excess oxygen over Na-modified $\mathrm{Pt} / \gamma-\mathrm{Al}_{2} \mathrm{O}_{3}$ catalysts. Appl. Catal. $B$ 2005, 56, 229-239. [CrossRef]

48. Kotsionopoulos, N.; Bebelis, S. In situ electrochemical modification of catalytic activity for propane combustion of $\mathrm{Pt} / \beta^{\prime \prime}-\mathrm{Al}_{2} \mathrm{O}_{3}$ catalyst-electrodes. Top. Catal. 2007, 44, 379-389. [CrossRef]

49. Kotsionopoulos, $\mathrm{N}$.; Bebelis, $\mathrm{S}$. Electrochemical characterization of the $\mathrm{Pt} / \beta^{\prime \prime}-\mathrm{Al}_{2} \mathrm{O}_{3}$ system under conditions of in situ electrochemical modification of catalytic activity for propane combustion. J. Appl. Electrochem. 2010, 40, 1883-1891. [CrossRef]

50. Auvray, X.; Lindholm, A.; Milh, M.; Olsson, L. The addition of alkali and alkaline earths metals to $\mathrm{Pd} / \mathrm{Al}_{2} \mathrm{O}_{3}$ to promote methane compustion. Effect of Pd and Ca loading. Catal. Today 2018, 299, 212-218. [CrossRef]

51. Williams, F.J.; Palermo, A.; Tikhov, M.S.; Lambert, R.M. Electrochemical promotion by sodium of the rhodium-catalysed NO + CO reaction. J. Phys. Chem. B 2000, 104, 11883-11890. [CrossRef]

52. Williams, F.J.; Palermo, A.; Tikhov, M.S.; Lambert, R.M. Mechanism of alkali promotion in heterogeneous catalysis under realistic conditions: Application of electron spectroscopy and electrochemical promotion to the reduction of NO by CO and by propene over rhodium. Surf. Sci. 2001, 482-485, 177-182. [CrossRef]

53. Konsolakis, M.; Yentekakis, I.V.; Palermo, A.; Lambert, R.M. Optimal promotion by rubidium of the CO + $\mathrm{NO}$ reaction over $\mathrm{Pt} / \gamma-\mathrm{Al}_{2} \mathrm{O}_{3}$ catalysts. Appl. Catal. B 2001, 33, 293-302. [CrossRef]

54. Konsolakis, M.; Yentekakis, I.V. NO reduction by propene or CO over alkali-promoted Pd/YSZ catalysts. J. Hazard. Mater. 2007, 149, 619-624. [CrossRef] [PubMed]

55. Tanikawa, K.; Egawa, C. Effect of barium addition over palladium catalyst for $\mathrm{CO}-\mathrm{NO}-\mathrm{O}_{2}$ reaction. J. Mol. Catal. A 2011, 349, 94-99. [CrossRef]

56. Lepage, M.; Visser, T.; Soulimani, F.; Inglesias-Juez, A.; Weckhuysen, B.M. Promotion Effects in the Reduction of NO by CO over Zeolite-Supported Rh Catalysts. J. Phys. Chem. C 2010, 114, 2282-2292. [CrossRef]

57. Harkness, I.R.; Lambert, R.M. Electrochemical Promotion of the NO + Ethylene Reaction over Platinum. J. Catal. 1995, 152, 211-214. [CrossRef]

58. Yentekakis, I.V.; Palermo, A.; Filkin, N.; Tikhov, M.S.; Lambert, R.M. In situ electrochemical promotion by sodium of the platinum-catalysed reduction of NO by propene. J. Phys. Chem. B 1997, 101, 3759-3768. [CrossRef]

59. Williams, F.J.; Palermo, A.; Tikhov, M.S.; Lambert, R.M. Electrochemical promotion by sodium of the rhodium-catalysed reduction of NO by propene: Kinetics and spectroscopy. J. Phys. Chem. B 2001, 105, 1381-1388. [CrossRef]

60. Williams, F.J.; Tikhov, M.S.; Palermo, A.; Macleod, N.; Lambert, R.M. Electrochemical promotion of rhodium-catalysed NO reduction by CO and by propene in the presence of oxygen. J. Phys. Chem. B 2001, 105, 2800-2808. [CrossRef]

61. Konsolakis, M.; Yentekakis, I.V. Strong promotional effects of Li, K, Rb and Cs on the Pt-catalysed reduction of NO by propene. Appl. Catal. B 2001, 29, 103-113. [CrossRef] 
62. Konsolakis, M.; Yentekakis, I.V. The reduction of $\mathrm{NO}$ by propene over Ba-promoted $\mathrm{Pt} / \gamma-\mathrm{Al}_{2} \mathrm{O}_{3}$ catalysts. J. Catal. 2001, 198, 142-150. [CrossRef]

63. Yentekakis, I.V.; Lambert, R.M.; Konsolakis, M.; Kallithrakas-Kontos, N. On the Effects of Residual Chloride and of Barium Promotion on $\mathrm{Pt} / \gamma-\mathrm{Al}_{2} \mathrm{O}_{3}$ Catalysts in the Reduction of NO by Propene. Catal. Lett. 2002, 81, 181-185. [CrossRef]

64. Macleod, N.; Isaac, J.; Lambert, R.M. Sodium promotion of the $\mathrm{NO}+\mathrm{C}_{3} \mathrm{H}_{6}$ reaction over $\mathrm{Rh} / \gamma-\mathrm{Al}_{2} \mathrm{O}_{3}$ catalysts. J. Catal. 2000, 193, 115-122. [CrossRef]

65. Yentekakis, I.V.; Lambert, R.M.; Konsolakis, M.; Kiousis, V. The effect of sodium on the Pd-catalysed reduction of NO by methane. Appl. Catal. B 1998, 18, 293-305. [CrossRef]

66. Yentekakis, I.V.; Konsolakis, M.; Kiousis, V.; Lambert, R.M.; Tikhov, M. Promotion by sodium in emission control catalysis: The difference between alkanes and alkenes in the Pd-catalysed reduction of NO by hydrocarbons. G-NEST Int. J. 1999, 1, 121-130.

67. Burch, R.; Watling, T.C. The difference between alkanes and alkenes in the reduction of NO by hydrocarbons over Pt catalysts under lean-burn conditions. Catal. Lett. 1997, 43, 19-23. [CrossRef]

68. Burch, R.; Sullivan, J.A.; Watling, T.C. Mechanistic considerations for the reduction of NOx over Pt/ $\mathrm{Al}_{2} \mathrm{O}_{3}$ and $\mathrm{Al}_{2} \mathrm{O}_{3}$ catalysts under lean-burn conditions. Catal. Today 1998, 42, 13-23. [CrossRef]

69. Goula, M.A.; Charisiou, N.D.; Papageridis, K.N.; Delimitis, A.; Papista, E.; Pachatouridou, E.; Iliopoulou, E.F.; Marnellos, G.; Konsolakis, M.; Yentekakis, I.V. A comparative study of the $\mathrm{H}_{2}$-assisted selective catalytic reduction of nitric oxide by propene over noble metal $(\mathrm{Pt}, \mathrm{Pd}, \mathrm{Ir}) / \gamma-\mathrm{Al}_{2} \mathrm{O}_{3}$ catalysts. J. Environ. Chem. Eng. 2016, 4, 1629-1641. [CrossRef]

70. Machida, M.; Ikeda, S.; Kurogi, D.; Kijima, T. Low temperature catalytic $\mathrm{NO}_{x}-\mathrm{H}_{2}$ reactions over Pt $/ \mathrm{TiO}_{2}-\mathrm{ZrO}_{2}$ in an excess oxygen. Appl. Catal. B 2001, 35, 107-116. [CrossRef]

71. Costa, C.N.; Savva, P.G.; Andronikou, C.; Lambrou, P.S.; Polychronopoulou, K.; Belessi, V.C.; Stathopoulos, V.N.; Pomonis, P.J.; Efstathiou, A.M. An Investigation of the $\mathrm{NO} / \mathrm{H}_{2} / \mathrm{O}_{2}$ (lean De-NOx) reaction on a highly active and selective $\mathrm{Pt} / \mathrm{La}_{0.7} \mathrm{Sr}_{0.2} \mathrm{Ce}_{0.1} \mathrm{FeO}_{3}$ catalyst at low temperatures. J. Catal. 2002, 209, 456-471. [CrossRef]

72. Polychronopoulou, K.; Efstathiou, A.M. $\mathrm{NO}_{x}$ control via $\mathrm{H}_{2}$-selective catalytic reduction $\left(\mathrm{H}_{2}\right.$-SCR) technology for stationary and mobile applications. Recent Pat. Mater. Sci. 2012, 5, 87-104. [CrossRef]

73. Burch, R.; Coleman, M.D. An Investigation of Promoter Effects in the Reduction of NO by $\mathrm{H}_{2}$ under Lean-Burn Conditions. J. Catal. 2002, 208, 435-447. [CrossRef]

74. Machida, M.; Watanabe, T. Effect of Na-addition on catalytic activity of Pt-ZSM-5 for low-temperature $\mathrm{NO}-\mathrm{H}_{2}-\mathrm{O}_{2}$ reactions. Appl. Catal. B 2004, 52, 281-286. [CrossRef]

75. Macleod, N.; Lambert, R.M. Low-temperature $\mathrm{NO}_{x}$ reduction with $\mathrm{H}_{2}+\mathrm{CO}$ under oxygen-rich conditions over a $\mathrm{Pd} / \mathrm{TiO}_{2} / \mathrm{Al}_{2} \mathrm{O}_{3}$ catalyst. Catal. Commun. 2002, 3, 61-65. [CrossRef]

76. Macleod, N.; Lambert, R.M. Lean $\mathrm{NO}_{x}$ reduction with $\mathrm{CO}+\mathrm{H}_{2}$ mixtures over $\mathrm{Pt} / \mathrm{Al}_{2} \mathrm{O}_{3}$ and $\mathrm{Pd} / \mathrm{Al}_{2} \mathrm{O}_{3}$ catalysts. Appl. Catal. B 2002, 35, 269-279. [CrossRef]

77. Macleod, N.; Lambert, R.M. In situ ammonia generation as a strategy for catalytic NOx reduction under oxygen rich conditions. Chem. Commun. 2003, 11, 1300-1301. [CrossRef]

78. Macleod, N.; Lambert, R.M. An in situ DRIFTS study of efficient lean $\mathrm{NO}_{x}$ reduction with $\mathrm{H}_{2}+\mathrm{CO}$ over $\mathrm{Pd} / \mathrm{Al}_{2} \mathrm{O}_{3}$ : The key role of transient $\mathrm{NCO}$ formation in the subsequent generation of ammonia. Appl. Catal. $B$ 2003, 46, 483-495. [CrossRef]

79. Konsolakis, M.; Vrontaki, M.; Avgouropoulos, G.; Ioannides, T.; Yentekakis, I.V. Novel doubly-promoted catalysts for the lean $\mathrm{NO}_{x}$ reduction by $\mathrm{H}_{2}+\mathrm{CO}: \mathrm{Pd}(\mathrm{K}) / \mathrm{Al}_{2} \mathrm{O}_{3}-\left(\mathrm{TiO}_{2}\right)$. Appl. Catal. B 2006, 68, 59-67. [CrossRef]

80. Wang, C.-B.; Chang, J.-G.; Wu, R.-C.; Yeh, C.-T. Promotion effect of coating alumina supported palladium with sodium hydroxide on the catalytic conversion of nitric oxide. Appl. Catal. B 1998, 17, 51-62. [CrossRef]

81. Haber, J.; Nattich, M.; Machej, T. Alkali-metal promoted rhodium-on-alumina catalysts for nitrous oxide decomposition. Appl. Catal. B 2008, 77, 278-283. [CrossRef]

82. Parres-Esclaped, S.; Lopez-Suerez, F.E.; Bueno-Lopez, A.; Illan-Gomez, M.J.; Ura, B.; Trawcczynski, J. $\mathrm{Rh}-\mathrm{Sr} / \mathrm{Al}_{2} \mathrm{O}_{3}$ catalyst for $\mathrm{N}_{2} \mathrm{O}$ decomposition in the presence of $\mathrm{O}_{2}$. Top. Catal. 2009, 52, 1832-1836. [CrossRef]

83. Konsolakis, M.; Aligizou, F.; Goula, G.; Yentekakis, I.V. $\mathrm{N}_{2} \mathrm{O}$ decomposition over doubly-promoted $\mathrm{Pt}(\mathrm{K}) / \mathrm{Al}_{2} \mathrm{O}_{3}-\left(\mathrm{CeO}_{2}-\mathrm{La}_{2} \mathrm{O}_{3}\right)$ structured catalysts: On the compined effects of promotion and feed composition. Chem. Eng. J. 2013, 230, 286-295. [CrossRef] 
84. Papista, E.; Pachatouridou, E.; Goula, M.A.; Marnellos, G.E.; Iliopoulou, E.; Konsolakis, M.; Yentekakis, I.V. Effect of alkali promoters (K) on nitrous oxide abatement over Ir/Al2O3 catalysts. Top. Catal. 2016, 59, 1020-1027. [CrossRef]

85. Goncalves, F.; Figueiredo, J.L. Sinergistic effect between $\mathrm{Pt}$ and $\mathrm{K}$ in the catalytic reduction of $\mathrm{NO}$ and $\mathrm{N}_{2} \mathrm{O}$. Appl. Catal. B 2006, 62, 181-192. [CrossRef]

86. Pekridis, G.; Kaklidis, N.; Konsolakis, M.; Iliopoulou, E.F.; Yentekakis, I.V.; Marnellos, G. Correlation of surface characteristics with catalytic performance of potassium promoted $\mathrm{Pd} / \mathrm{Al}_{2} \mathrm{O}_{3}$ catalysts: The case of $\mathrm{N}_{2} \mathrm{O}$ reduction by alkanes or alkenes. Top. Catal. 2011, 54, 1135-1142. [CrossRef]

87. De Lucas-Consuegra, A.; Dorado, F.; Jimenez-Borja, C.; Valerde, J.L. Influence of the reaction conditions on the electrochemical promotion by potassium for the selective catalytic reduction of $\mathrm{N}_{2} \mathrm{O}_{\text {by }} \mathrm{C}_{3} \mathrm{H}_{6}$ on platinum. Appl. Catal. B 2008, 78, 222-231. [CrossRef]

88. De Lucas Consuegra, A.; Dorado, F.; Jimenez-Borja, C.; Valverde, J.L. Electrochemical promotion of Pt impregnated catalyst for the treatment of automotive exhaust emissions. J. Appl. Electrochem. 2008, 38, 1151-1157. [CrossRef]

89. Konsolakis, M.; Macleod, N.; Isaac, J.; Yentekakis, I.V.; Lambert, R.M. Strong promotion by Na of $\mathrm{Pt} / \gamma-\mathrm{Al}_{2} \mathrm{O}_{3}$ catalysts operated under simulated exhaust conditions. J. Catal. 2000, 193, 330-337. [CrossRef]

90. Macleod, N.; Isaac, J.; Lambert, R.M. Sodium promotion of $\mathrm{Pd} / \gamma-\mathrm{Al}_{2} \mathrm{O}_{3}$ catalysts operated under simulated "three-way" conditions. J. Catal. 2001, 198, 128-135. [CrossRef]

91. Macleod, N.; Isaac, J.; Lambert, R.M. A comparison of sodium-modified $\mathrm{Rh} / \gamma-\mathrm{Al}_{2} \mathrm{O}_{3}$ and $\mathrm{Pd} / \gamma-\mathrm{Al}_{2} \mathrm{O}_{3}$ catalysts operated under simulated TWC conditions. Appl. Catal. B 2001, 33, 335-343. [CrossRef]

92. Tanaka, T.; Yokota, K.; Isomura, N.; Doi, H.; Sugiura, M. Effect of the addition of Mo and Na to Pt catalysts on the selective reduction of NO. Appl. Catal. B 1998, 16, 199-208. [CrossRef]

93. Shinjoh, H.; Tanabe, T.; Sobukawa, H.; Sugiura, M. Effect of Ba addition on catalytic activity of Pt and Rh catalysts loaded on $\gamma$-alumina. Top. Catal. 2001, 16/17, 95-99. [CrossRef]

94. Kobayashi, T.; Yamada, T.; Kayano, K. Effect of basic metal additives on $\mathrm{NO}_{\mathrm{x}}$ reduction property of Pd-based three-way catalyst. Appl. Catal. B 2001, 30, 287-292. [CrossRef]

95. Yentekakis, I.V.; Konsolakis, M.; Rapakousios, I.A.; Matsouka, V. Novel electropositively promoted monometallic (Pt-only) catalytic converters for automotive pollution control. Top. Catal. 2007, 42-43, 393-397. [CrossRef]

96. Matsouka, V.; Konsolakis, M.; Lambert, R.M.; Yentekakis, I.V. In situ DRIFTS study of the effect of structure $\left(\mathrm{CeO}_{2}-\mathrm{La}_{2} \mathrm{O}_{3}\right)$ and surface $(\mathrm{Na})$ modifiers on the catalytic and surface behaviour of $\mathrm{Pt} / \gamma-\mathrm{Al}_{2} \mathrm{O}_{3}$ catalyst under simulated exhaust conditions. Appl. Catal. B 2008, 84, 715-722. [CrossRef]

97. Matsouka, V.; Konsolakis, M.; Yentekakis, I.V.; Papavasiliou, A.; Tsetsekou, A.; Boukos, N. Thermal aging behavior of Pt-only TWC converters under simulated exhaust conditions: Effect of rare earths $\left(\mathrm{CeO}_{2}, \mathrm{La}_{2} \mathrm{O}_{3}\right)$ and alkali (Na) modifiers. Top. Catal. 2011, 54, 1124-1134. [CrossRef]

98. Papavasiliou, A.; Tsetsekou, A.; Matsouka, V.; Konsolakis, M.; Yentekakis, I.V.; Boukos, N. Synergistic structural and surface promotion of monometallic (Pt) TWCs: Effectiveness and thermal aging tolerance. Appl. Catal. B 2011, 106, 228-241. [CrossRef]

99. Vernoux, P.; Gaillard, F.; Lopez, C.; Siebert, E. Coupling catalysis to electrochemistry: A solution to selective reduction of nitrogen oxides in lean-burn engine exhausts? J. Catal. 2003, 217, 203-208. [CrossRef]

100. Dorado, F.; de Lucas-Consuegra, A.; Jimenez, C.; Valverde, J.L. Influence of the reaction temperature on the elecrochemical promoted catalytic behaviour of platinum impregnated catalysts for the reduction of nitrogen oxides under lean burn conditions. Appl. Catal. A 2007, 321, 86-92. [CrossRef]

101. Dorado, F.; de Lucas-Consuegra, A.; Vernoux, P.; Valverde, J.L. Electrochemical promotion of platinum impregnated catalyst for the selective catalytic reduction of $\mathrm{NO}$ by propene in presence of oxygen. Appl. Catal. B 2007, 73, 42-50. [CrossRef]

102. De Lucas Consuegra, A.; Caravaca, A.; Dorado, F.; Valverde, J.L. Pt/K- $\beta \mathrm{Al}_{2} \mathrm{O}_{3}$ solid electrolyte cell as a "smart electrochemical catalyst" for the effective removal of $\mathrm{NO}_{x}$ under wet reaction conditions. Catal. Today 2009, 146, 330-335. [CrossRef]

103. De Lucas Consuegra, A.; Caravaca, A.; Sanchez, P.; Dorado, F.; Valverde, J.L. A new improvement of catalysis by solid-state electrochemistry: An electrochemically assisted $\mathrm{NO}_{x}$ storage/reduction catalyst. J. Catal. 2008, 259, 54-65. [CrossRef] 
104. De Lucas Consuegra, A.; Caravaca, A.; Martin de Vidales, M.J.; Dorado, F.; Balomenou, S.; Tsiplakides, D.; Vernoux, P.; Valverde, J.L. An electrochemically assisted $\mathrm{NO}_{x}$ storage/reduction catalyst operating under fixed lean burn conditions. Catal. Commun. 2009, 11, 247-251. [CrossRef]

105. Burch, R.; Watling, T.C. The effect of promoters on $\mathrm{Pt} / \mathrm{Al}_{2} \mathrm{O}_{3}$ catalysts for the reduction of $\mathrm{NO}$ by $\mathrm{C}_{3} \mathrm{H}_{6}$ under lean-burn conditions. Appl. Catal. B 1997, 11, 207-216. [CrossRef]

106. Vernoux, P.; Leinekugel-Le-Cocq, A.-Y.; Gaillard, F. Effect of the addition of $\mathrm{Na}$ on $\mathrm{Pt} / \mathrm{Al}_{2} \mathrm{O}_{3}$ catalysts for the reduction of $\mathrm{NO}$ by $\mathrm{C}_{3} \mathrm{H}_{8}$ and $\mathrm{C}_{3} \mathrm{H}_{6}$ under lean-burn conditions. J. Catal. 2003, 219, 247-257. [CrossRef]

107. Wogerbauer, C.; Maciejewski, M.; Schubert, M.M.; Baiker, A. Effect of sodium on the catalytic properties of iridium black in the selective reduction of NOx by propene under lean-burn conditions. Catal. Lett. 2001, 74, 1-7. [CrossRef]

108. Goula, G.; Katzourakis, P.; Vakakis, N.; Papadam, T.; Konsolakis, M.; Tikhov, M.; Yentekakis, I.V. The effect of potassium on the $\mathrm{Ir} / \mathrm{C}_{3} \mathrm{H}_{6}+\mathrm{NO}+\mathrm{O}_{2}$ catalytic system. Catal. Today 2007, 127, 199-206. [CrossRef]

109. Vayenas, C.G.; Koutsodontis, C.G. Non-Faradaic electrochemical activation of catalysis. J. Chem. Phys. 2008, 128, 182506-182513. [CrossRef]

110. Lambert, R.M. Catalysis and Electrocatalysis at Nanoparticles; Wieckowski, A., Savinova, E., Vayenas, C.G., Eds.; Dekker: New York, NY, USA, 2003; p. 583.

111. Lambert, R.M.; Palermo, A.; Williams, F.J.; Tikhov, M.S. Electrochemical promotion of catalytic reactions using alkali ion conductors. Solid State Ionics 2000, 136-137, 677-685. [CrossRef]

112. Lang, N.D.; Holloway, S.; Norskov, J.K. Electrostatic adsorbate-adsorbate interactions: The poisoning and promotion of the molecular adsorption reaction. Surf. Sci. 1985, 150, 24-38. [CrossRef]

113. Koukiou, S.; Konsolakis, M.; Lambert, R.M.; Yentekakis, I.V. Spectroscopic evidence for the mode of action of alkali promoters in Pt-catalyzed de-NOx chemistry. Appl. Catal. B 2007, 76, 101-106. [CrossRef]

114. Vayenas, C.G.; Brosda, S. Electron donation-backdonation and the rules of catalytic promotion. Top. Catal. 2014, 57, 1287-1301. [CrossRef]

115. Blyholder, G. Molecular orbital view of chemisorbed carbon monoxide. J. Phys. Chem. 1964, 68, $2772-2778$. [CrossRef]

116. Harkness, I.R.; Lambert, R.M. Chemisorption and reactivity of nitric oxide on Na-dosed platinum\{111\}. J. Chem. Soc. Faraday Trans. 1997, 93, 1425-1429. [CrossRef]

117. Garfunkel, E.L.; Maj, J.J.; Frost, J.C.; Farias, M.H.; Somorjai, G.A. Interaction of potassium with .pi.-electron orbital containing molecules on platinum(111). J. Phys. Chem. 1983, 87, 3629-3635. [CrossRef]

118. Bertolini, J.C.; Derichele, P.; Massardier, J. The influence of potassium and the role of coadsorbed oxygen on the chemisorptive properties of Pt(100). Surf. Sci. 1985, 160, 531-541. [CrossRef]

119. Pitchon, V.; Primet, M.; Praliaud, H. Alkali addition to silica-supported palladium: Infrared investigation of the carbon monoxide chemisorptions. Appl. Catal. 1990, 62, 317-334. [CrossRef]

120. Liotta, F.L.; Martin, G.A.; Deganello, G. The influence of alkali metal ions in the chemisorption of CO and $\mathrm{CO}_{2}$ on supported palladium catalysts: A fourier transform infrared spectroscopic study. J. Catal. 1996, 164, 322-333. [CrossRef]

121. Vayenas, C.G.; Archonta, D.; Tsiplakides, D. Scanning tunneling microscopy observation of the origin of electrochemical promotion and metal-support interactions. J. Electroanal. Chem. 2003, 554-555, 301-306. [CrossRef]

122. Makri, M.; Vayenas, C.G.; Bebelis, S.; Besocke, K.H.; Gavalca, C. Atomic resolution STM imaging of electrochemically controlled reversible promoter dosing of catalysts. Surf. Sci. 1996, 369, 351-359. [CrossRef]

123. Archonta, D.; Frantzis, A.; Tsiplakides, D.; Vayenas, C.G. STM observation of the origin of electrochemical promotion on metal catalyst-electrodes interfaced with YSZ and $\beta^{\prime \prime}-\mathrm{Al}_{2} \mathrm{O}_{3}$. Solid State Ionics 2006, 26-32, 2221-2225. [CrossRef]

124. Gonzalez-Cobos, J.; de Lucas-Consuegra, A. A Review of surface analysis techniques for the investigation of the phenomenon of electrochemical promotion of catalysis with alkaline ionic conductors. Catalysts 2016, 6, 15. [CrossRef]

(C) 2019 by the authors. Licensee MDPI, Basel, Switzerland. This article is an open access article distributed under the terms and conditions of the Creative Commons Attribution (CC BY) license (http:/ / creativecommons.org/licenses/by/4.0/). 